Universidad Politécnica de Madrid

Escuela Técnica Superior de Arquitectura

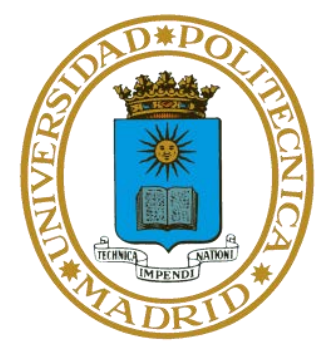

\title{
THE ORIGIN OF THE ISLAMIC RIBBED VAULTS FAMED \\ IN NORTH AFRICA AND SPAIN
}

By

RANA M. ALKADI

Architect

\begin{abstract}
A thesis submitted to the graduate faculty
of Conservation and Restoration of Architectural Heritage Department for the Degree of Doctor of Philosophy
\end{abstract}

Advise: J osé Carlos Palacios 

To my father who believed in the importance of education 


\section{ACKNOWLEDGMENT}

I thank God for accepting my prayers not to stop learning and reaching a high level in education to be able to spread knowledge from people to people.

I would like to express my deepest gratitude to my Father and Mother for their patience during my studies.

My sincerest thanks to Supervisor: Professor Jose Carlos Palacios for his guidance, support and valuable contributions throughout the preparations for this thesis and for giving me a great inner strength to success. It would be unfair not to mention the greatest support provided by the Department Secretary, Christina Villalba, for being a great friend and help during my research studies. 


\begin{abstract}
Islamic Architecture went through several periods of time. During its peak, numerous Islamic dynasties had been developed which resulted in the creation of new forms of architecture. When Islam started rising, it focused on spreading its faith among people in the Arabian Peninsula. Later, it concentrated on expanding to neighbourhood districts outside the Arabian Peninsula reaching Iraq, Syria, Egypt, Iran, North Africa and parts of Europe. These expansions developed rapid transformation in Architecture. The enormous extent of the Islamic Empire had developed independent dynasties over time. Each independent dynasty had a central political and geographical location, which created an individual art in architecture. These dynasties created a recognized architectural designs and methodologies, some influenced by previous Civilizations, some influenced by the characteristics of the regions in which they developed and some follows the influence of Islamic religious philosophies. Throughout history, new branches of Islamic beliefs had been created and new sub independent dynasties had been developed. This raise a research question to investigate on: The origin of the Islamic Ribbed Vaults, which famed in North Africa and Spain. The research paper takes a comprehensive analysis of civilizations that were founded before Islam in North Africa and Spain and resulted in the development of the Islamic Ribbed Vaults, which popped particularly during the eighth century. It also, traces the development of the Islamic Ribbed Vaults since it's initiated until it reached North Africa and Spain. Previous research papers analysed a certain period of time or region but none had traced the development of the Islamic Ribbed Vaults since its birth. To this end, the thesis investigates on the Islamic Ribbed Vaults development in Dessert Castles, Fortresses, Mosques and Mausoleums. The results of which are expected to open doors for new papers in the field of Islamic Ribbed Vaults, types, and construction Method.
\end{abstract}




\section{TABLE OF CONTENTS}

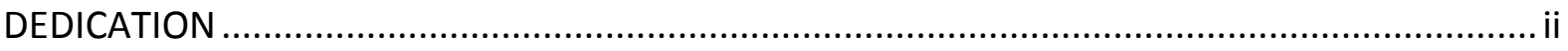

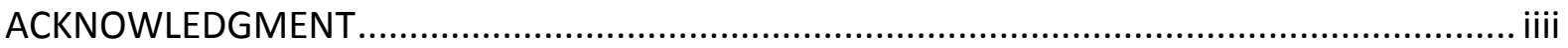

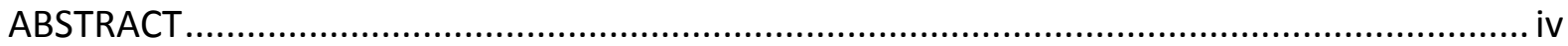

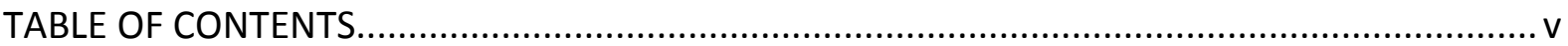

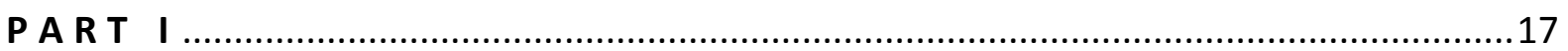

1. INTRODUCTION

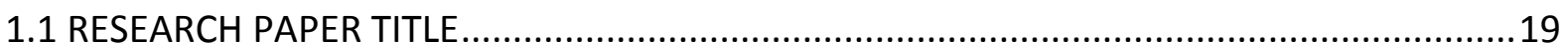

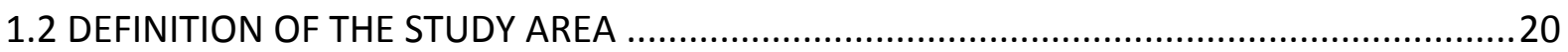

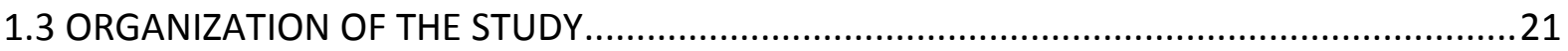

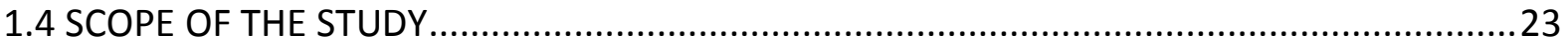

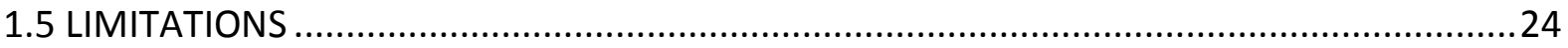

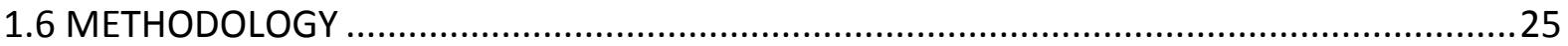

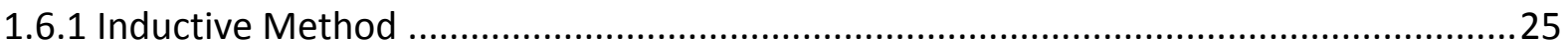

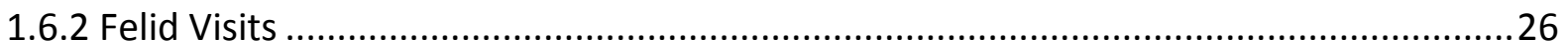

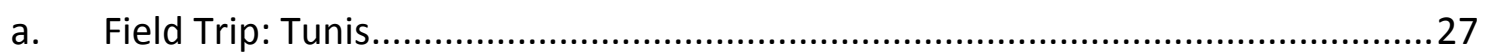

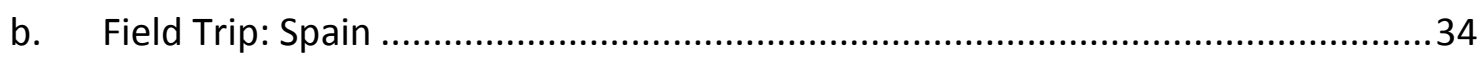

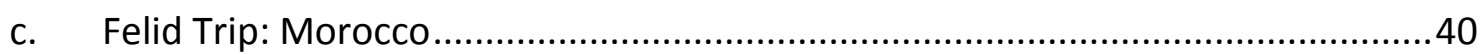

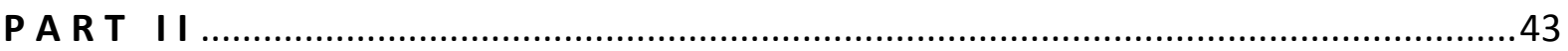

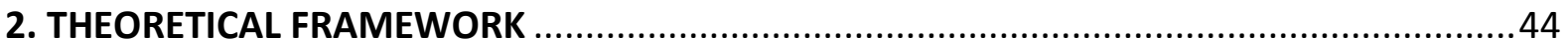

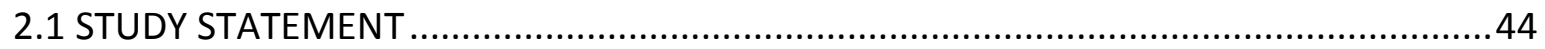

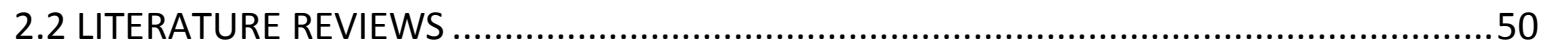




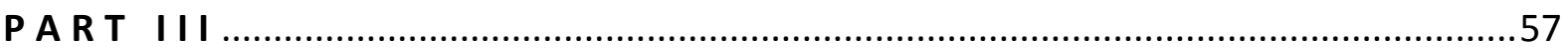

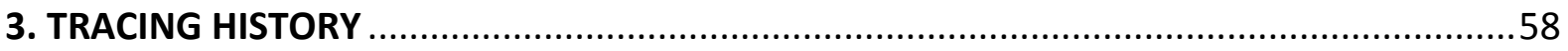

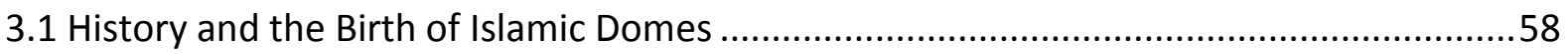

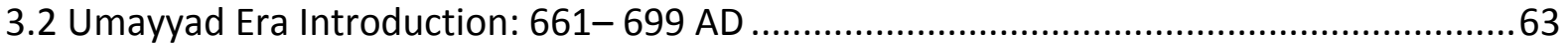

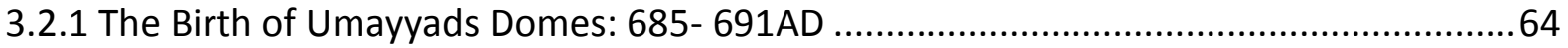

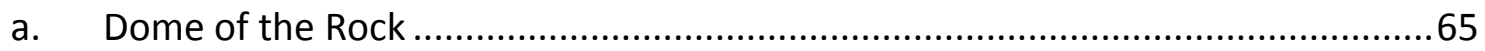

3.2.2 Umayyads Desert Castles Domes: 720- 750 AD......................................................68

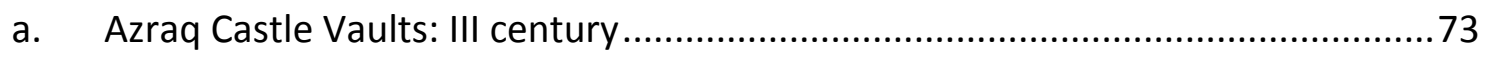

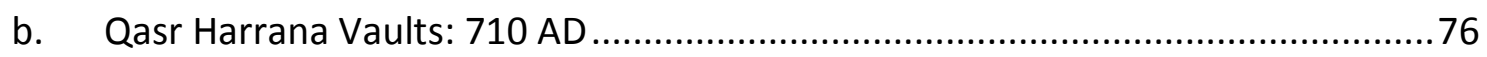

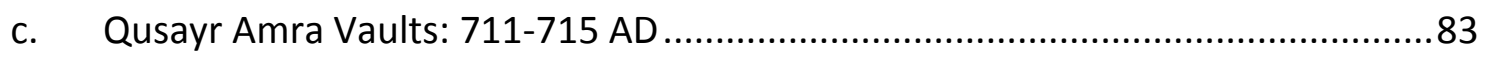

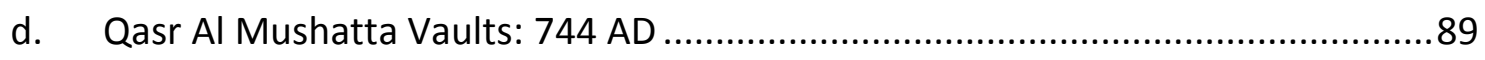

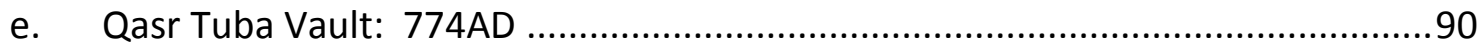

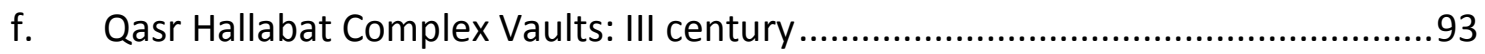

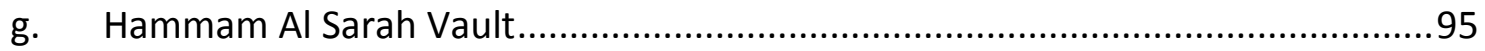

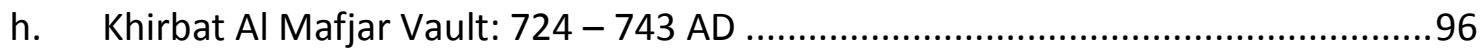

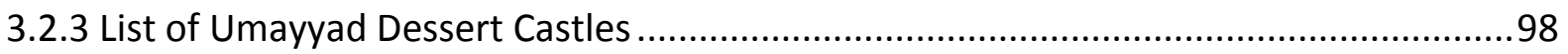

3.2.3.1 Type of Vaults in Umayyad Dessert Castles ................................................ 100

3.2.4 Umayyad Emirates Domes in Islamic Iberia: 711-899 AD ........................................101

3.2.5 Umayyad Caliphates Domes in Islamic Iberia: 912- 999 AD ......................................111

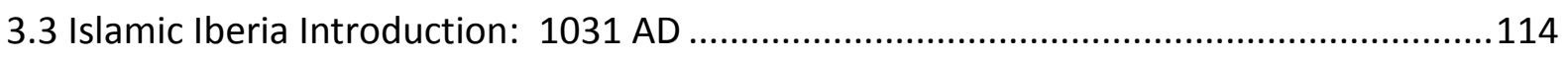

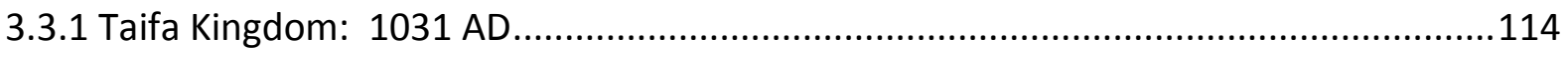

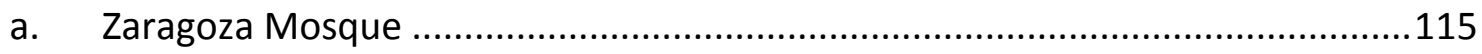

3.3.2 Moravid Introduction: 1056- 1091 until 1146 AD ................................................117

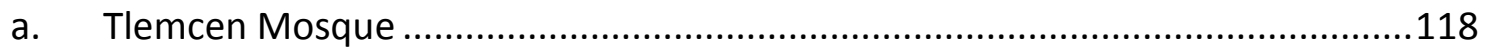

3.3.2.1 Marrakesh Introduction 1120 until 1184 AD ......................................................121 


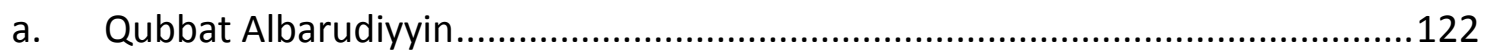

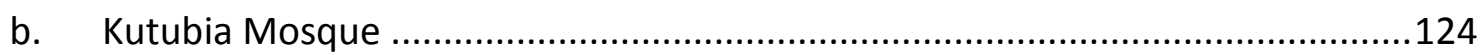

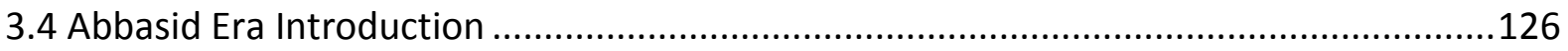

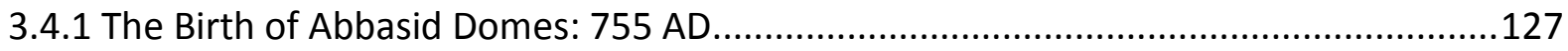

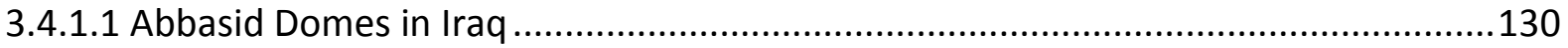

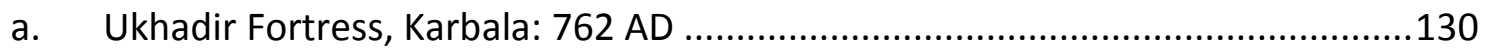

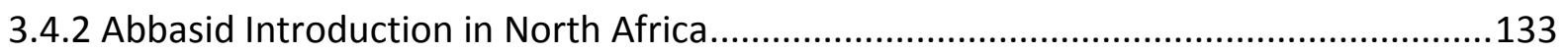

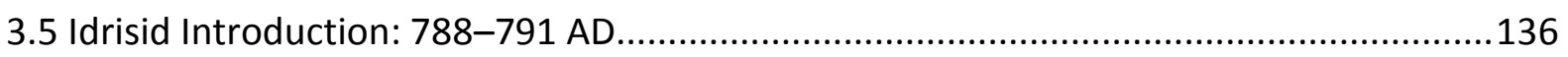

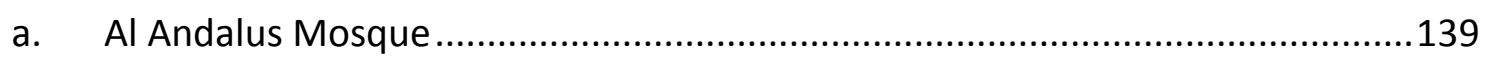

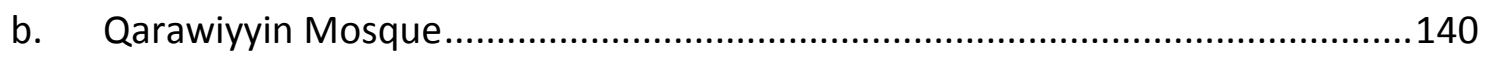

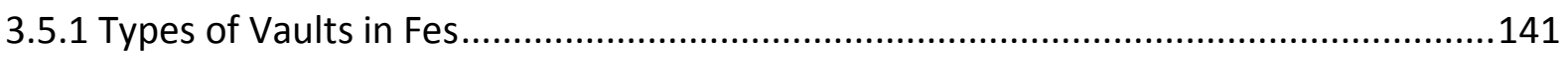

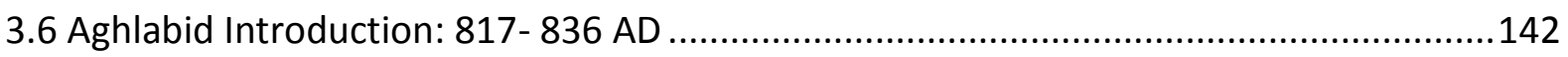

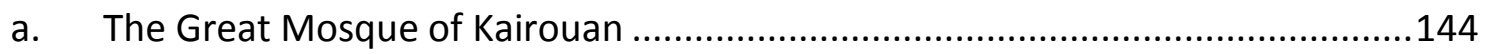

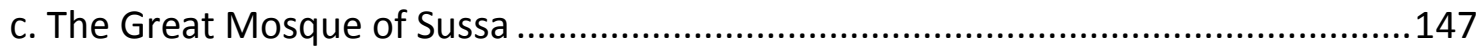

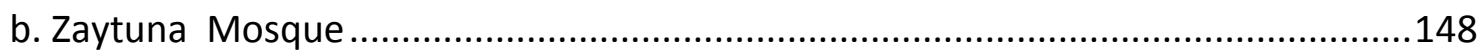

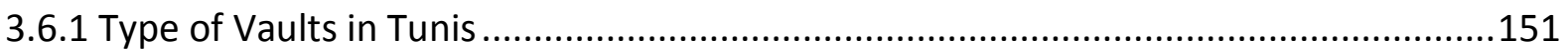

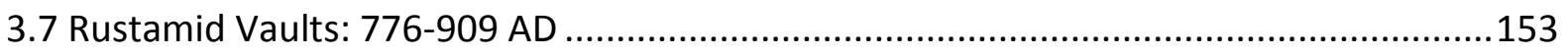

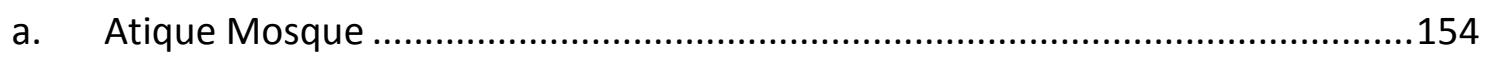

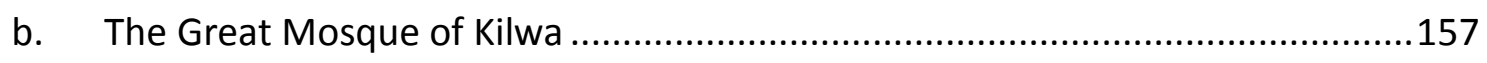

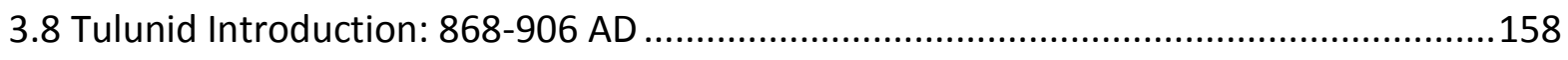

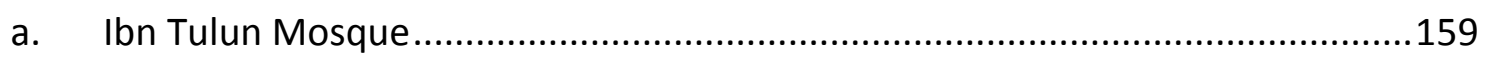

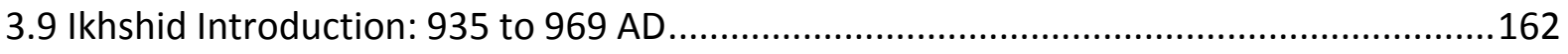

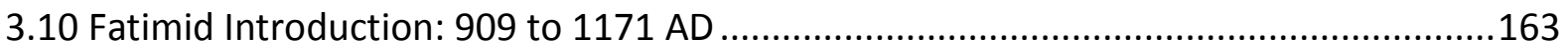

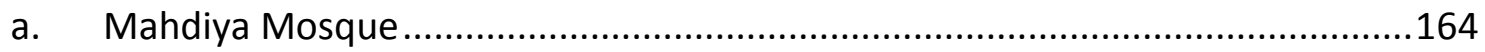

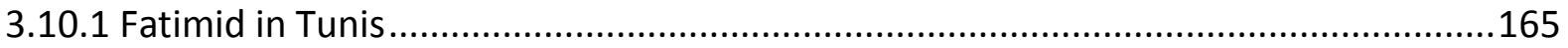


3.10.2 Fatimid in Cairo .165

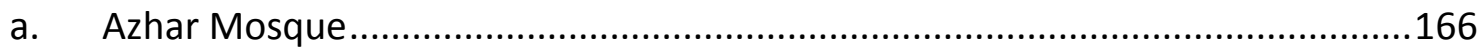

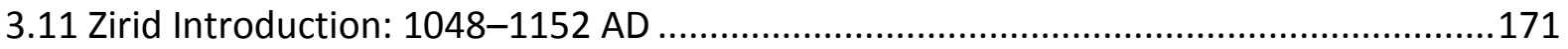

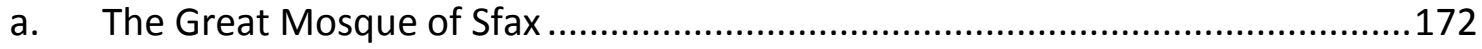

3.4.3 Abbasid Introduction in Central Asia: 750-1258 AD ..............................................175

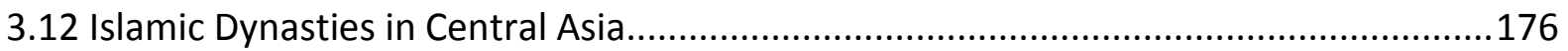

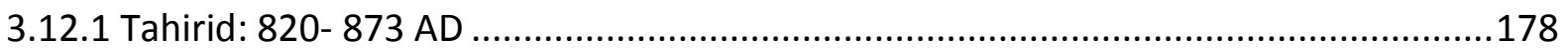

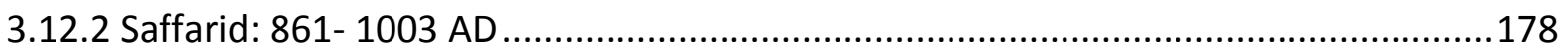

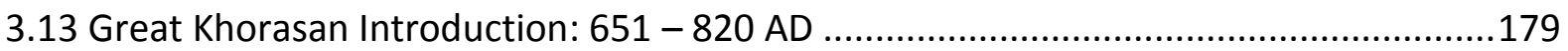

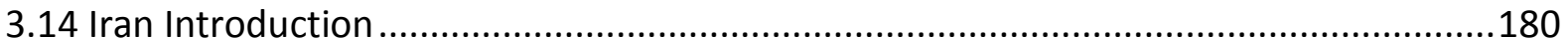

3.14.1 Iran Domes from Zoroastrians to Muslim Era ......................................................180

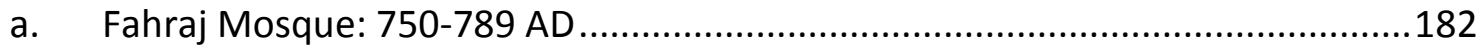

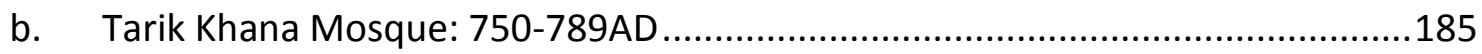

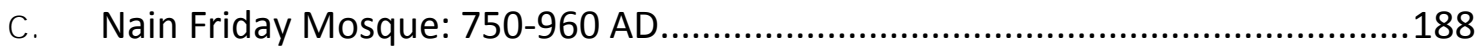

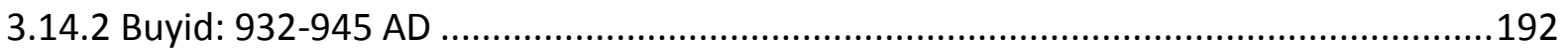

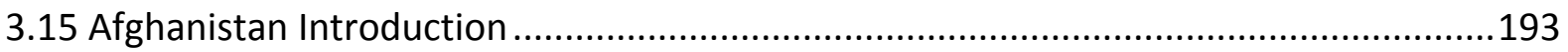

3.15.1 No Gumbad Mosque Birth: Nine Domed Mosques ................................................193

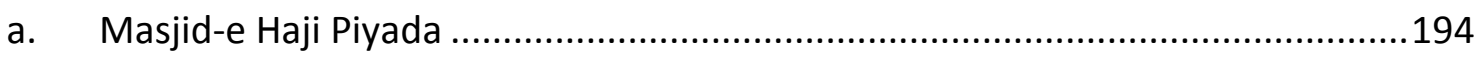

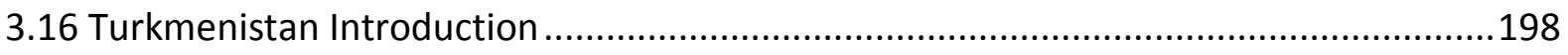

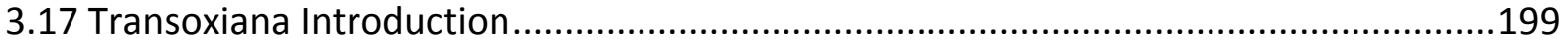

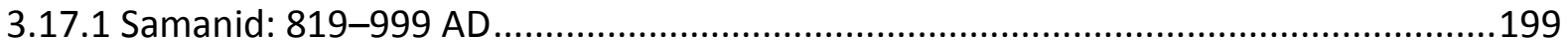

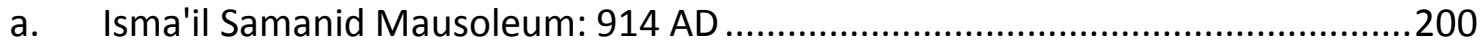

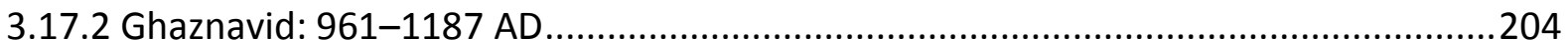

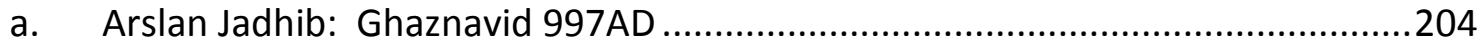

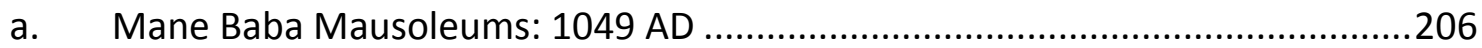




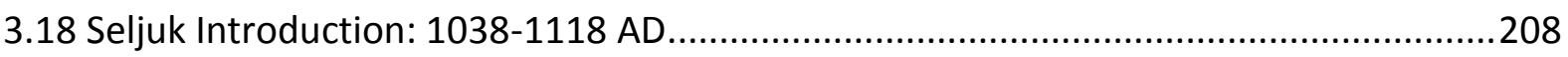

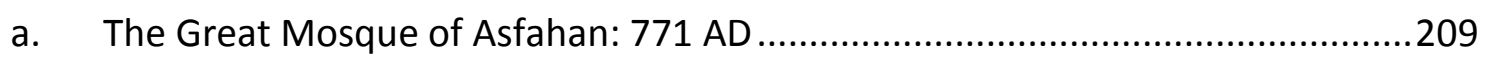

3.18.1 Monumental Anatolian Seljuq Architecture: 1077-1308 AD .................................216

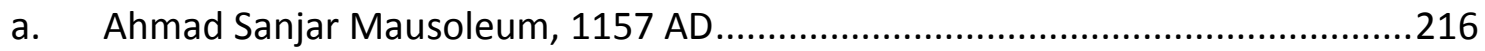

3.19 Factors for Vault Evolution from East to West ........................................................220

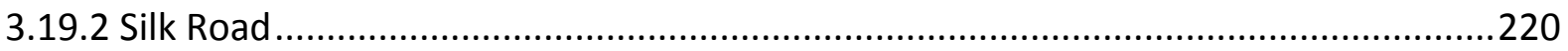

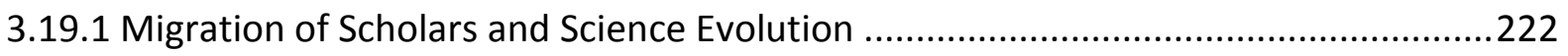

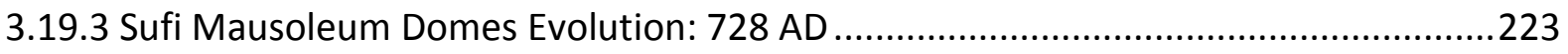

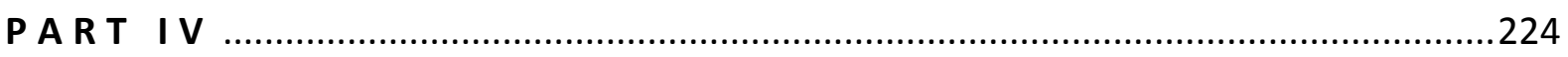

4. DEVELOPMENT OF VAULTS FROM ANCIENT CIVILIZATIONS TO ISLAM .......................225

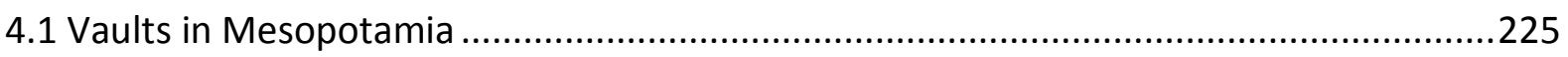

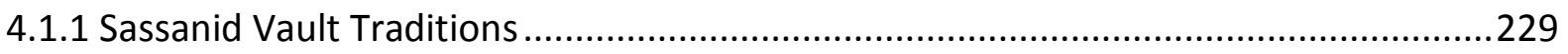

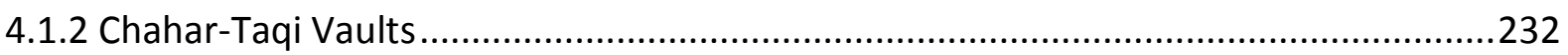

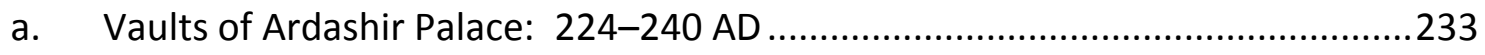

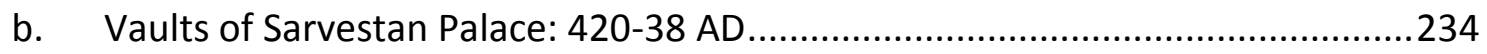

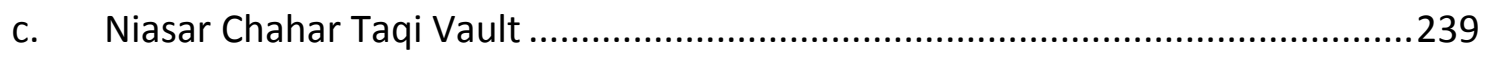

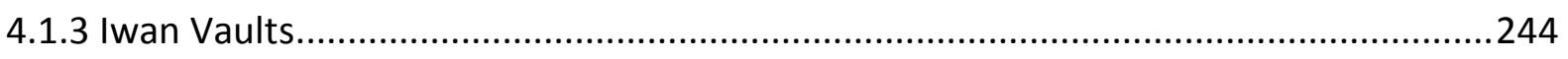

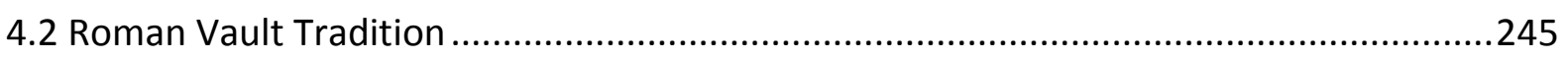

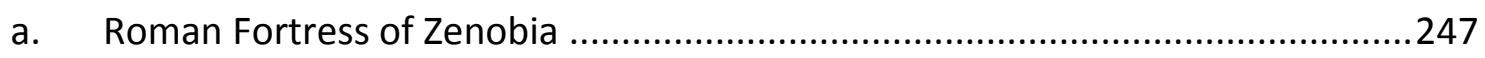

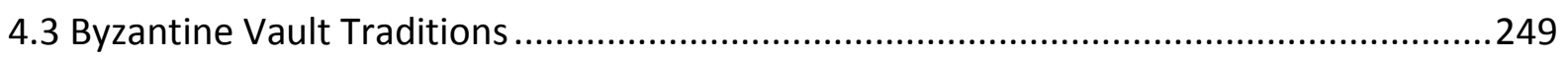

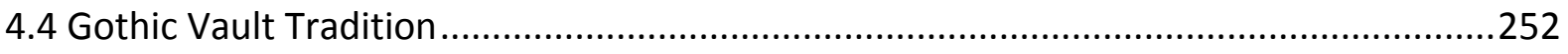

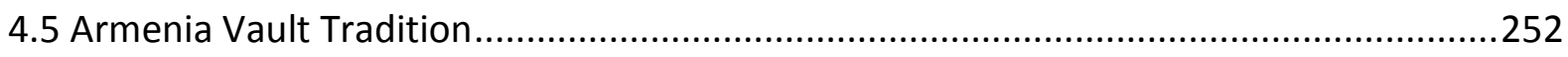

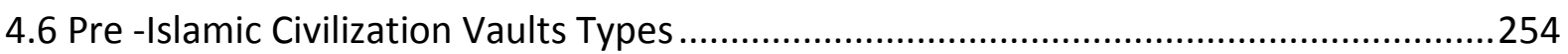

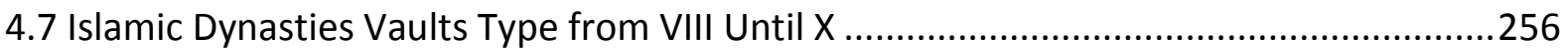




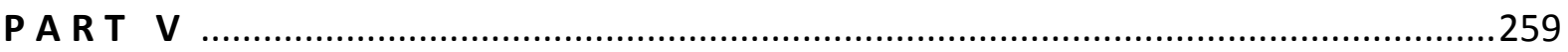

5. HYBRIDIZATION AND DEVELOPMENT OF ISLAMIC RIBBED VAULTS ............................260

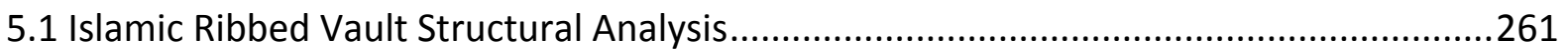

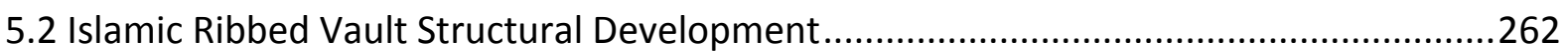

5.3 Islamic Ribbed Vault Brick Methods until Geometry.................................................264

5.4 Islamic Vault Development through History until Geometry ........................................267

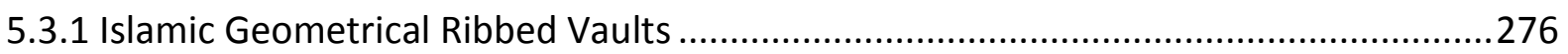

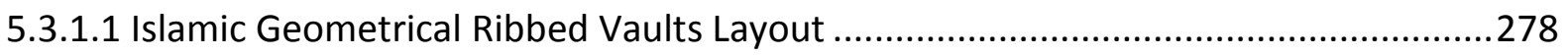

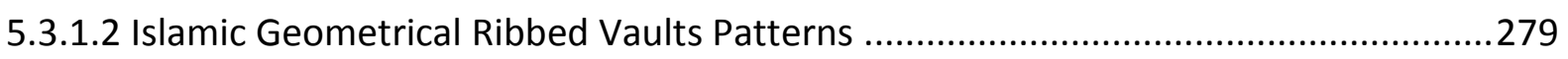

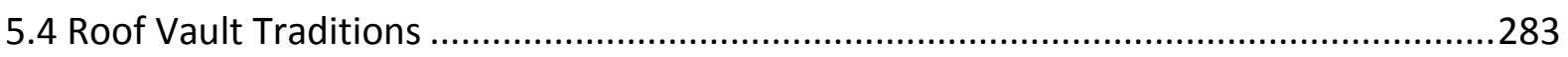

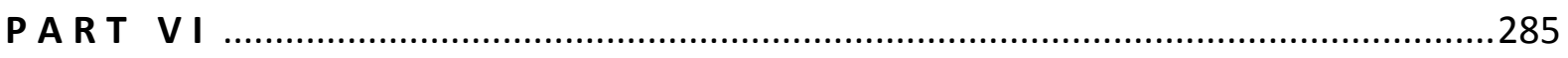

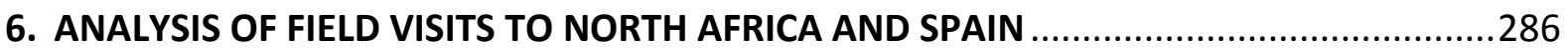

6.1 Development of Ribbed Vaults in North Africa .........................................................286

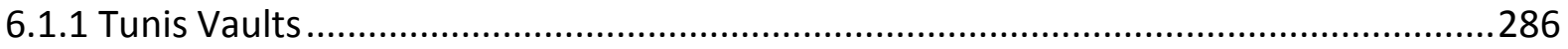

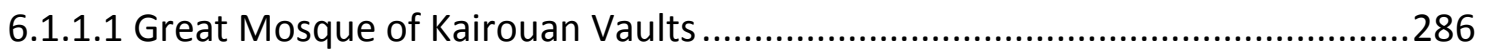

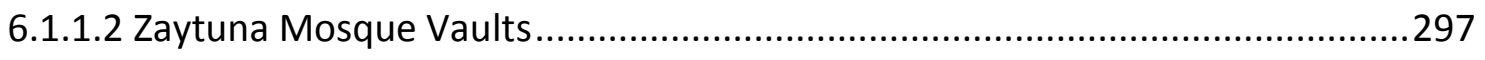

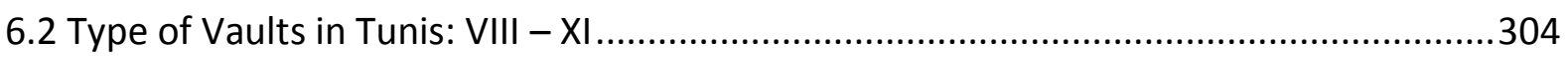

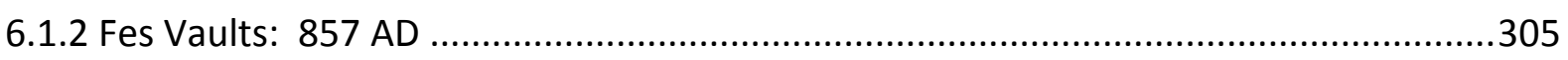

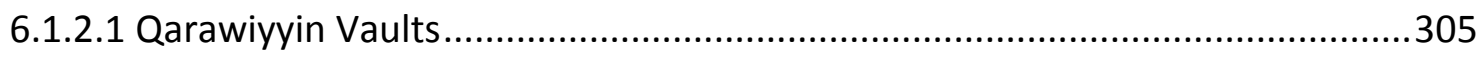

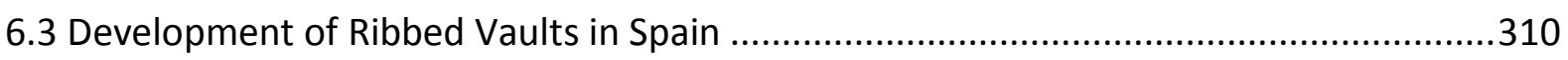

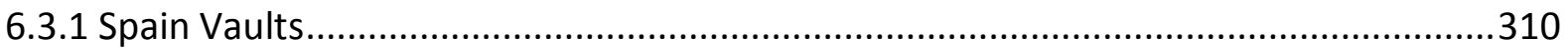

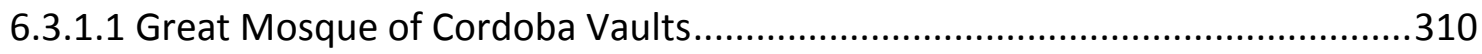

6.3.1.1.a Great Mosque of Cordoba Cross Arches Analysis .......................................313

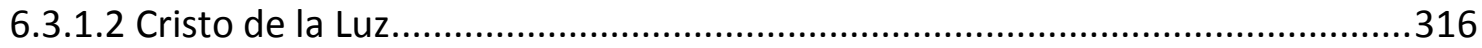




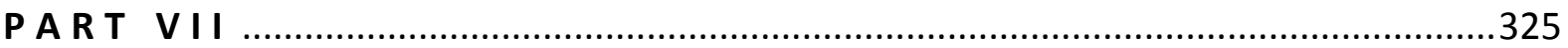

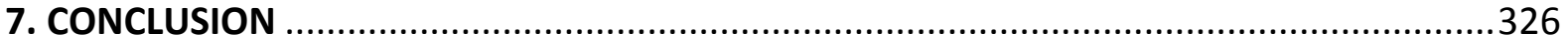

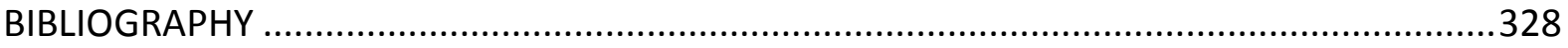

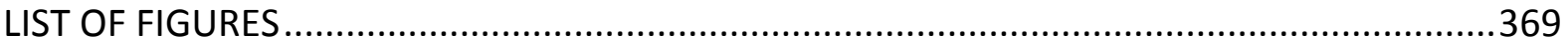

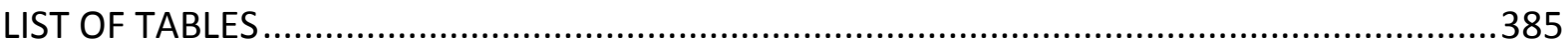

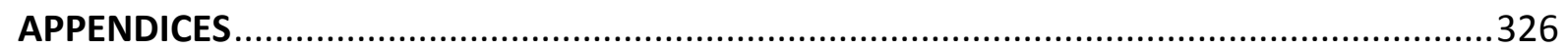

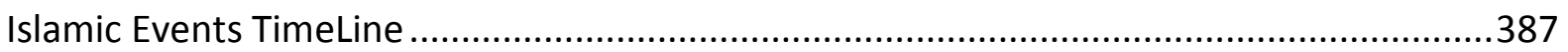

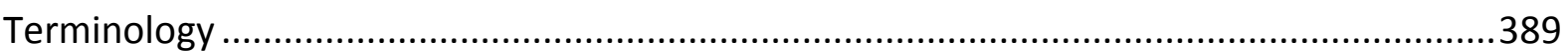

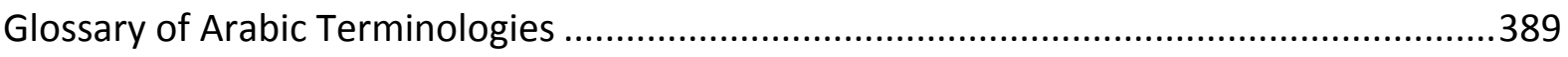

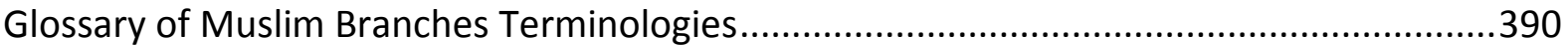

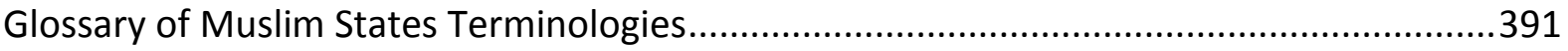

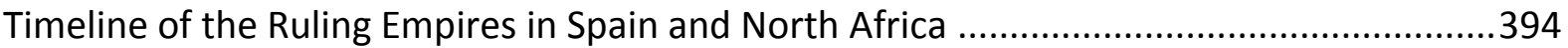

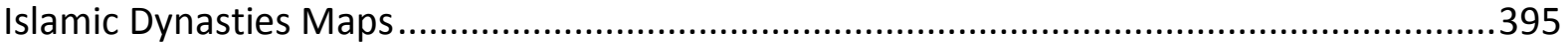

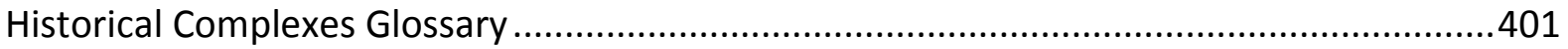


PART I

1. INTRODUCTION 


\section{INTRODUCTION}

Islamic Architecture comprises wide range of regional and religious designs. The speed of the Islamic faith towards the Atlantic and Pacific Oceans had created several sub Islamic Dynasties which produced variety of Islamic architectural artwork and designs. Theses designs had added to the Islamic characteristic context. The enlargement of The Islamic religion outside the border of the Arabian Peninsula had introduced ancient Civilization's artwork to the Islamic world ever since Roman, Byzantine and Persian Architecture [1]. The Architectural methodologies of previous regional cultures had inspired Muslim believers to create their own masterpieces of art by reproducing the earlier architectural work imbedded with Islamic philosophies to create particular art named Islamic Architecture. However, the huge field of Islamic Architecture is a subject of separated articles consequently seeking a strong requirement of scholarly interest toward different topics of Islamic arguments in architecture. This study particularly investigates and focuses on the origin of the early Islamic Ribbed Vaults famed in North Africa and Spain. The study explores the birth of the Islamic ribbed vaults, its origin, typologies and structural methods used through history in particular in North Africa and Spain. Artisans outside the Arabian Peninsula who accepted Islam as a religion had enriched the Islamic architecture art by forming the Islamic patterns into three Dimensional Architectural elements.
[1] Taqui Abdin mentioned on his Research Paper: A historic perspective of the architecture of the Islamic world with special reference to Cairo stating: 'Although the Arabs were able to conquer so many countries in a short space of time, they did not initially have an effect on the architecture of the occupied nations. Since the main aim of the conquest was to introduce the new religion to the world, the initial influence of the Arabs was spiritual rather than material.'

Then added:

'This allowed the cultures of the newly conquered lands to influence Islamic art.' (Abdin, 2010) 
The Islamic Ribbed Vault is one of the outcomes of the Islamic extent worldwide.

Islamic Ribbed Vaults are recognized historically by different terms: Islamic Cross Arches domes, Criss-cross Vaults, Cross Ribbed Vaults, or Vaults without centering. Different names of equivalent innovation of vaulting methods. Historians and researchers are still debating on the origin of the Islamic Ribbed Vaults and its relation to Roman, Armenian, Byzantine and Persian vaulting structure. This had developed a questions to be answer in this research study: From where the Islamic Vaults are originated, when was the birth of the Islamic Ribbed Vaults and where? What civilizations had influenced the Islamic vault innovations through its expansions before and after reaching North Africa and Spain? The paper purposes a deep historical attention to the history of the Islamic Ribbed Vaults starting from the Arabian Peninsula $t$ to the East then west until it arrived to North Africa and Islamic Iberia.

\subsection{RESEARCH PAPER TITLE}

The Origin of the Islamic Ribbed Vaults Famed in North Africa and Spain. 


\subsection{DEFINITION OF THE STUDY AREA}

The Research Study investigates the origin of Islamic Ribbed Vaults since the birth of Islam and through its expansions until it reached North Africa and Spain.

Throughout history, several Islamic dynasties had been developed as well as new branches of Islamic beliefs, as a result new sub-dynasties became independent from the original great empires and created their individual architectural elements that reflects their dynasty. These architectural developments were affected by the geological building materials, characteristic of the region, previous civilization's construction methodologies, which had distinguished one art from the other.

For a clear view of history, the study highlights on the Islamic dynasties, regional as well as ancient Civilizations that influenced the development of Islamic Ribbed Vaults since pre-Islamic periods, and the birth of Islam until its peak when it arrived to North Africa and Spain.

For this conclusion, the research paper provides scholarly understanding of the historical development of the Ribbed Vaults methodologies, typologies and structure methods through time.

The study answers the following questions:

When and where was the birth of the Islamic Ribbed Vaults?

What civilizations had influenced the Islamic vaulting methods?

How did vaults develop in North Africa and Spain?

The result of these questions provides historical analysis for the development of Islamic Ribbed Vaults particularly during the eight century.

The outcomes, introduces the birth of Islamic Ribbed Vaults in North Africa and Spain. A comparison and analysis of different methodologies used through history to explore the development and growth of the Islamic Ribbed Vaults in Spain, Tunis and Morocco since early centuries. 


\subsection{ORGANIZATION OF THE STUDY}

This study, which is divided into seven parts to investigates the origins and development of the Islamic ribbed vaults and non-centering vaulting methods since before the birth of Islam until Islam had reached North Africa and Spain.

PART I provides an introduction to the research. It includes the title, provides definitions, extensions, and discusses the organization, purpose and scope of the research study.

PART II reviews the literature on Ribbed Vault researches and studies done by scholars. It also draws on published articles and books in the fields of philosophy, history, and the history of Islamic art and architecture. This review contributes to the development of the theoretical framework in order to create a theoretical context base for the research study.

PART III traces the history of Islamic expansions until it arrived to North Africa and Spain, thereby providing a historical background for the various factors that affected the architectural vaulting methods used in North Africa and Spain with particular attention to historical Monuments, Palaces, fortress and Mosques that contain Islamic Ribbed Vaults. This Part of the research paper, explores Islamic historical monuments as they developed during the time period under consideration, including Islamic dynasties and ancient civilizations architecture that influenced the Islamic architecture, with particular attention being given to the introduction of Islamic Ribbed Vaults into Islamic architectural art. 
PART IV reviews the history of Ancient Civilizations: Mesopotamia, Sassanid, Byzantine, Roman, Gothic and Armenian ribbed vaults developments, types and hybridization to Islam.

PART V develops a classificatory system for analyzing the Islamic Ribbed vault construction methods, typography and structure as it developed in the early monuments of North Africa and Spain.

PART VI develops analysis of the field visits to North Africa and Spain. The vault construction methods, typography and structure developed in North Africa since the arrival of Islam including: The Great Mosque of Kairouan and Zaytuna Mosque in Tunis. In addition to the vaults in the Qarawiyyin Mosque in Morocco and The Great Mosque of Cordoba, Almeria Great Mosque, Cristo de la Luz and Al Ja'fariya Palace in Spain.

PART VII devotes to conclusion that presents recommendations to open doors for studies of researches in Islamic art and Architecture and produce an area for scholars to investigate in new studies of the same filed. 


\subsection{SCOPE OF THE STUDY}

Inconsistency of the doubts results of previous research studies in the field of Islamic Vaults, limited conclusions and little reachable information. In addition, to the lack of languages and the sensitive topic in the Islamic religious branches and believes. The lack of studies of the analytical researches devoted exclusively to the origin of the Islamic Ribbed Vaults made this research study required for the need of an academic research study on the origin of the Islamic Vaults famed during history. It is essential to recompense the small number of studies that investigate on the formation of the Islamic Ribbed Vaults before Islam and resulted into developing the cross arched vaults to history and practically North Africa and Spain. The study attempts to answer a key question, whether the methodologies of the Islamic Ribbed Vaults extracted from previous civilizations or it is an Islamic invention of the regions characteristics. Several research papers in related topic have approached an introduction to this field but there is no deep historical analysis that tackled the subject intensively. Sources of different languages: Arabic, English, Persian and Spanish are essential to analysis and develop an understandings of the historical development of the Islamic Vaults origin. This research opens doors for future research questions in the Islamic architectural wide field. The different types of Islamic Ribbed Vaults that have been developed in North Africa and Spain invented great historical Art work to Muslim's complexes. The study will understand the history development of the Vaults methodologies since the birth of Islam. As a conclusion, this will open doors for new papers in the field of Islamic Ribbed Vaults history, types and construction methodologies. 


\subsection{LIMITATIONS}

This research traces the expansion of Islam from the Arabian Peninsula going north to the Levant, then East to Persia and Central Asia, then West until its arrival to Spain. Given that the primary intension of this research paper is to survey the origin of Islamic ribbed vaults of North Africa and Spain, the major methodical approach highlights the Islamic buildings from the birth of Islamic Architecture until it arrival to North Africa and Spain. It is significant because it provides an initial understanding of the chronological and regional development of Islamic Vaults. The research will contribute to the understanding of the characteristics of Islamic Vaults through history. The study covered a massive capacity of Islamic lands, dynasties and their Monuments until it reached North Africa and Spain. But there are thousands of monuments scattered throughout the Islamic word. For this, a close examination of the early monuments built during Islam that contain all type of ribbed vaults had to be analysed since the eight century. This makes the study contains Ancient fortresses, Dessert Castles, Mausoleums, and early Mosques from East to West that were built in the eight century. [1]. As a result, an extensive study is taken on the history of Islamic buildings passing through all Islamic dynasties. The conclusion to examine early surviving complexes all over the Islamic world from Spain to Central Asia, so that no area is unpresented and all Islamic vaults introduced. The shortage of research papers had been treated as a challenge then as a disadvantage. 


\subsection{METHODOLOGY}

\subsubsection{Inductive Method}

This study begins by examining the existing scholarship on Ribbed Vaults as they developed in North Africa and Spain from classical antiquity to the Islamic period. This involved extensive reading of documents, books, articles and reviews in English, Arabic, Spanish, French and Persian. In particular, these sources were drawn from the fields of philosophy, history and Islamic art and architecture. This level of research was necessary to provide an appropriate theoretical context for the broad scope of the study [1].

The research also required on-site visits to historical monuments in Spain, Morocco and Tunisia. It initially included visits to several Islamic Iberian monuments: Cristo de la Luz in Toledo, Mosque of Cordoba in Andalusia, San Juan in Almeria, and Al Ja'fariya in Zaragoza. These visits were part of the observation approach in order to absorb the ribbed vaults constructed from the eight through the tenth century in Spain. Urban sketching, measurements, and photo shooting were used to analyse these monuments. Later, three historical monuments in Fes, Morocco: Alashraf, Qarawiyyin and Alandalus Mosques. These visits required the permission of the Ministry of Islamic Affairs of Morocco, which manages and supervises the Historical Mosques in Morocco.

Since females are not allowed to enter the male's section of the Mosques, and since the Mihrab ${ }^{1}$ is always located where the Imam who leads the prayer in the male section, for this,

\footnotetext{
${ }^{1}$ Niche in the wall of the mosque that indicates the direction of the Ka'aba in Mecca
}

[1] Inductive approach starts with the observations and theories are formulated towards the end of the research and as a result of observations (Goddard and Melville, 2004) 
Permissions were required for one hour of photo shooting in and outside of of each mosque including their roofs .

Following the trip to Morocco, a visit was made to two cities in Tunis: Tunis City and Kairouan, where the first mosques in North Africa were built. This was necessary to compare the different developments of the ribbed vault to understand their historical architectural evolution. The felid visits comprises: Documentary Videos, high resolution Photo, sketches and site measurements, notes, drawings and field dimensions of the required sites. Later, a bus trip from Kairouan City to Al Zaytuna Mosque in Tunis City to view the differences in the Architectural Methods used in constructing. The analysis of the gathered data has been conducted using an Inductive Approach. The inductive method starts with many observations, with the goal of finding powerful statements or theory.

\subsubsection{Felid Visits}

It could not be able to reach to a conclusion without undertaking numerous visits to virtualize the North African Monuments as well as Spain. This approach was important in order to survey the Islamic Ribbed vaults from North Africa to Spain. An on-site field visits to the historical monuments located in Spain and North Africa passing through cities in Morocco and Tunisia in order to be able to analysis the development of the Islamic Ribbed Vaults. The field visits started by Cristo de la luz in Toledo, then Mosque of Cordoba in Andalusia, San Juan in Almeria to Al Ja'fariya in Zaragoza. These visits were part of the observation approach in order to absorb the Iberia ribbed vaults in comparison to the early historical monuments located in North Africa during the eight until the tenth century.

Tunis [Figure 1]

The Great Mosque of Kairouan: [Figure 2-12].

Al Zaytuna Mosque: [Figure 13-15].

Spain: [Figure 18]

The Great Mosque of Cordoba: [Figure 17-23].

The Great Mosque of Almeria: [Figure 24- 25].

Morocco [Figure 26]

Qarawiyyin Mosque [Figure 27-32] 
a. Field Trip: Tunis

i. Kairouan Mosque

ii. Zaytuna Mosque

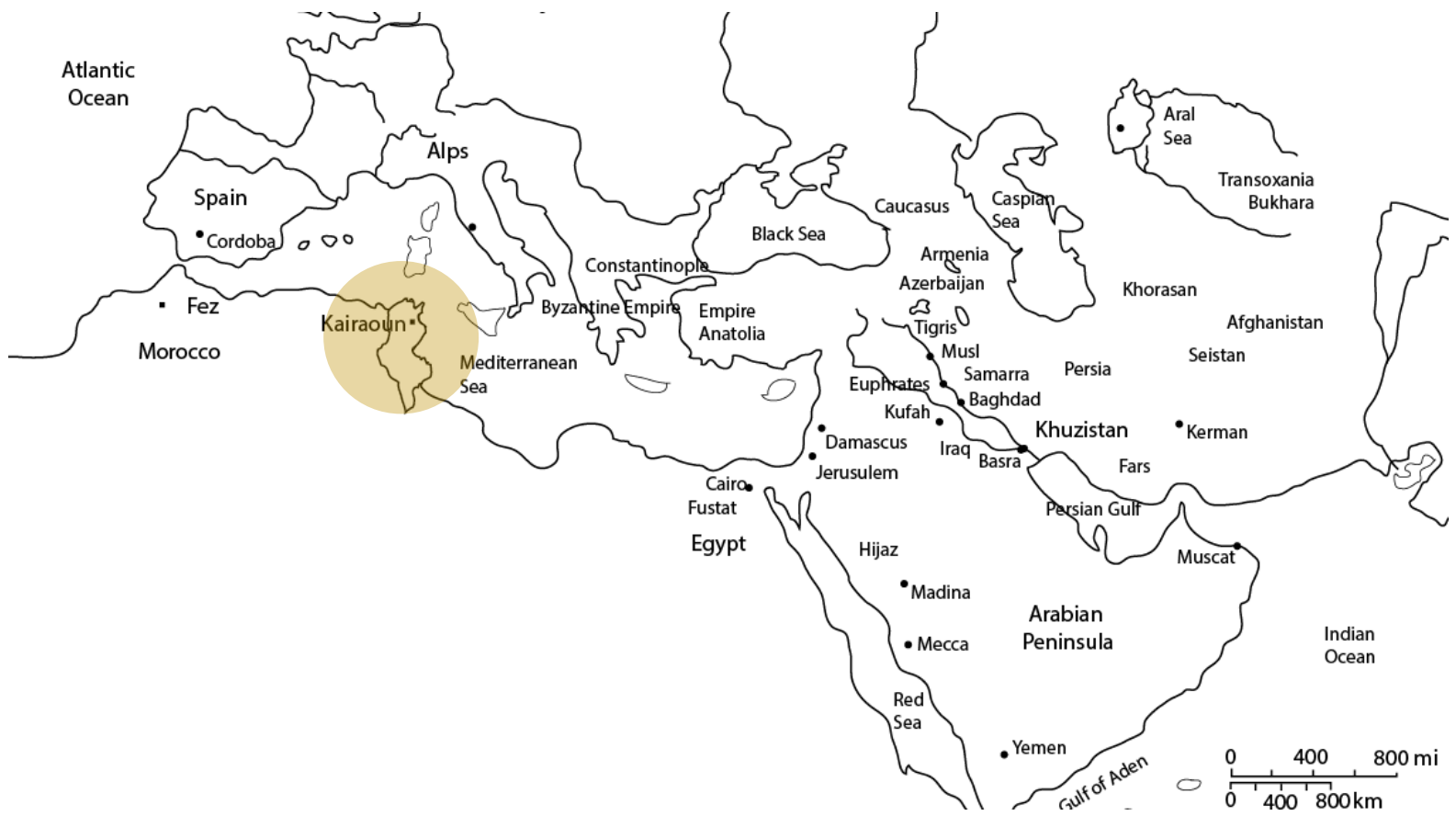

Figure 1: Filed Visit to Tunis 


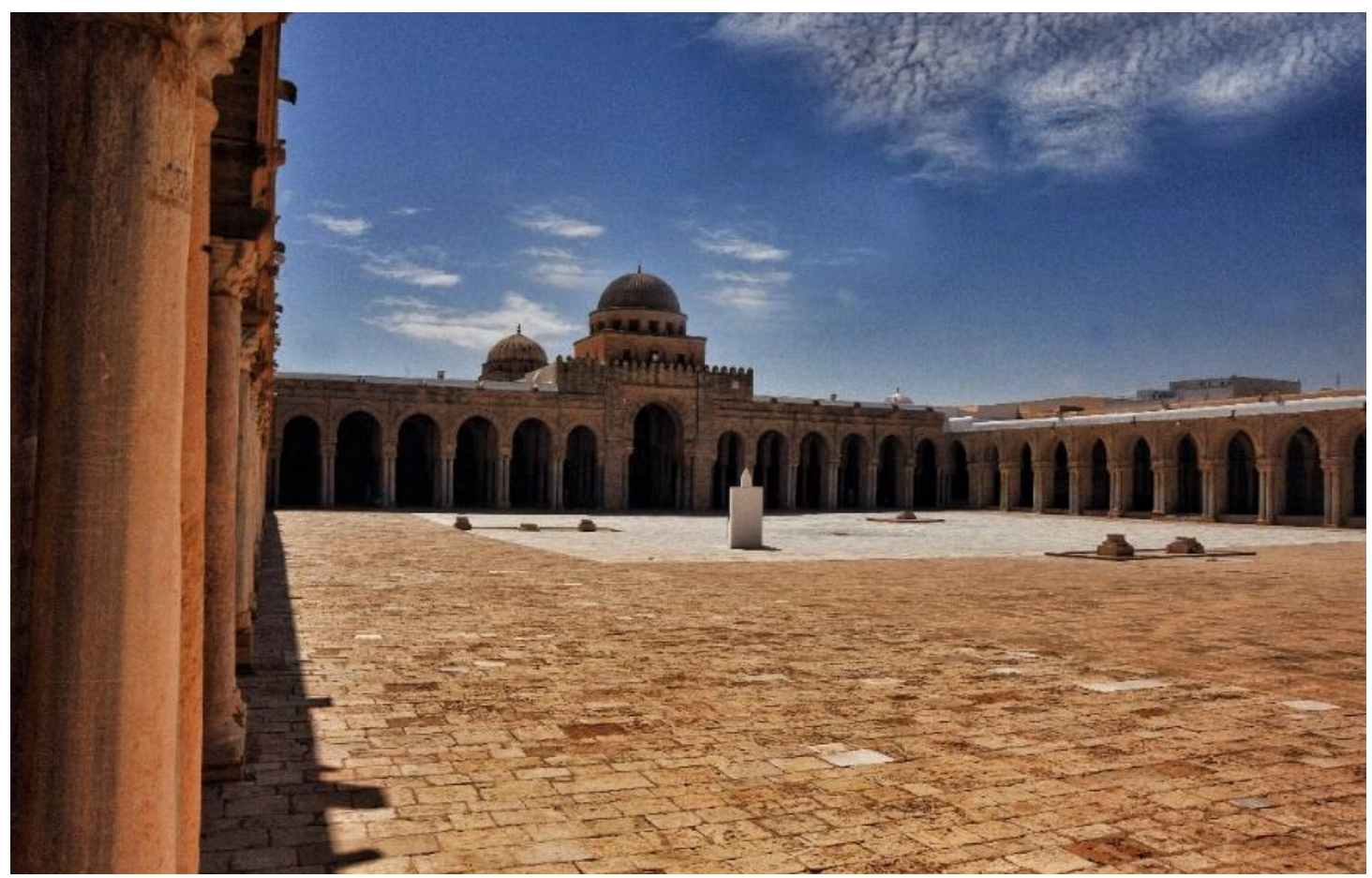

Figure 2: The Great Mosque of Kairouan View.

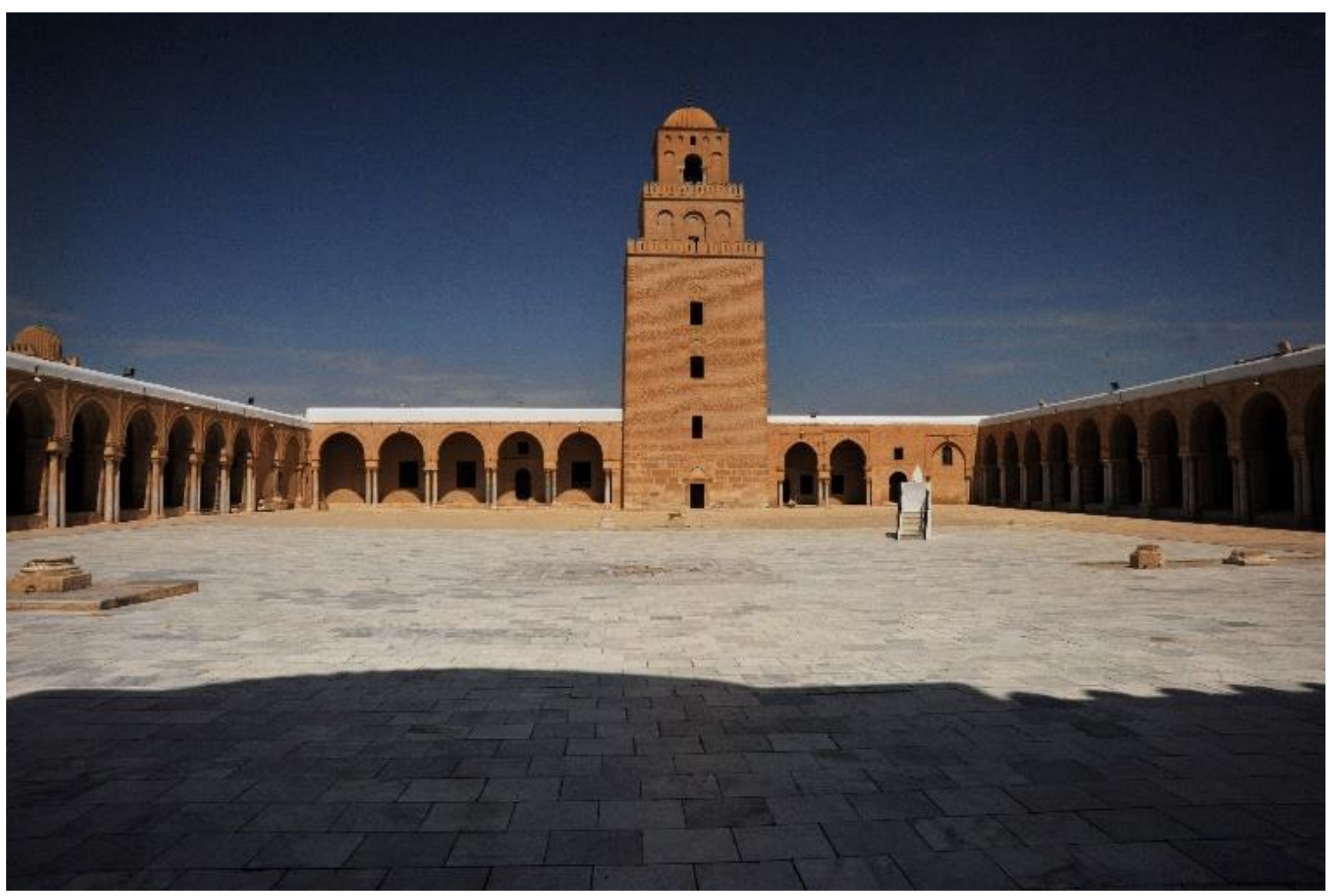

Figure 3: The Great Mosque of Kairouan Court.

Source: Photos by the Author 


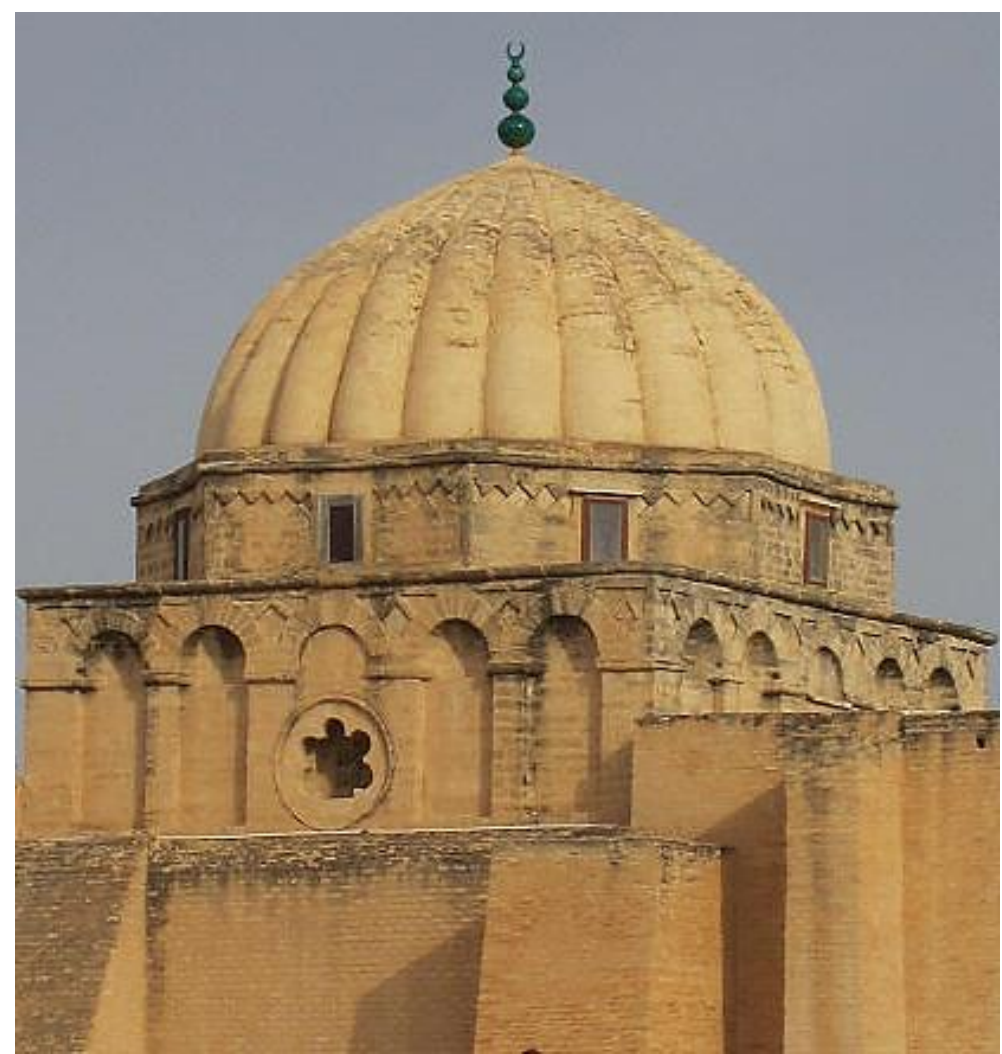

Figure 4: Mihrab Dome.

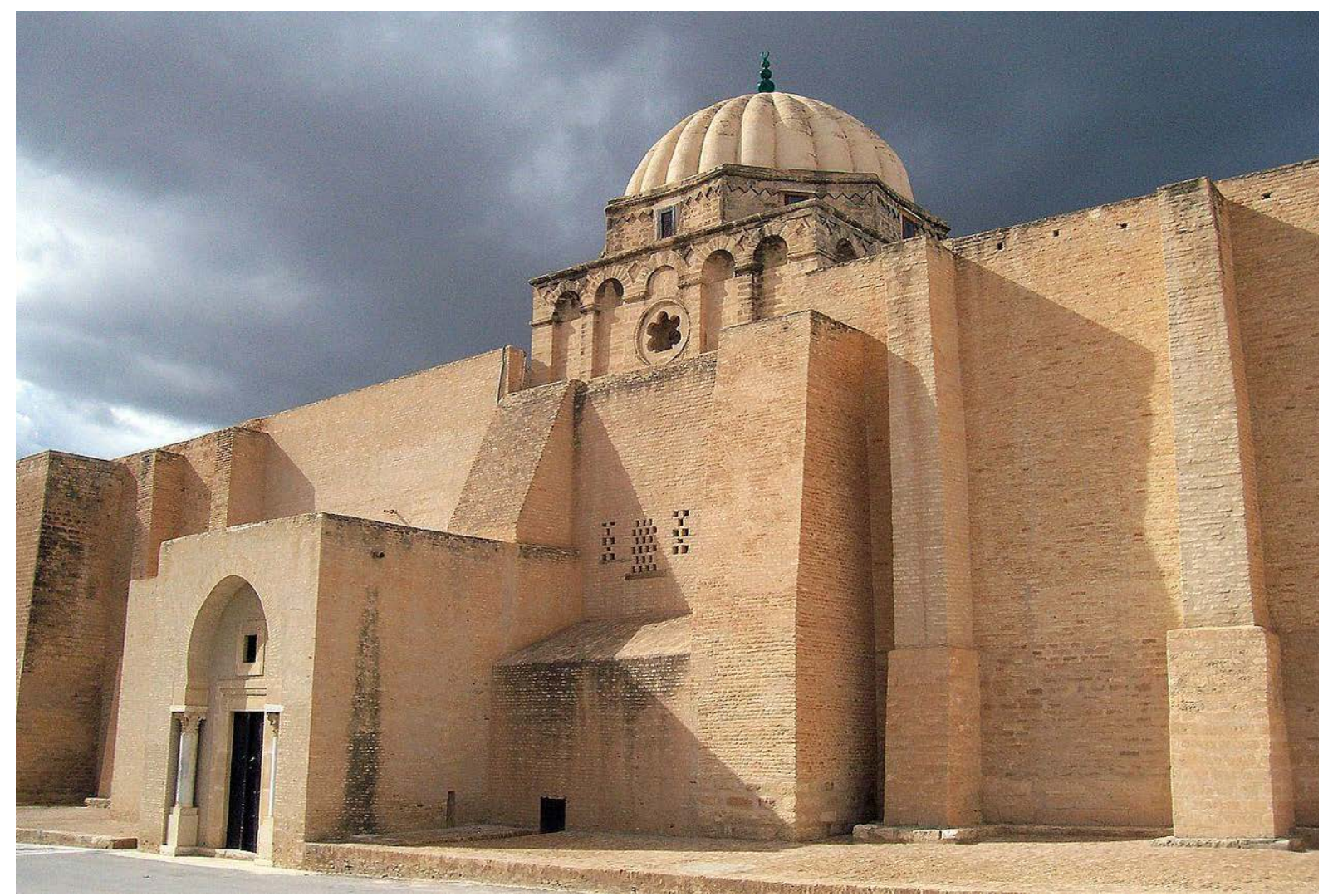

Figure 5: Mihrab Dome Exterior View Source: Photos by the Author 


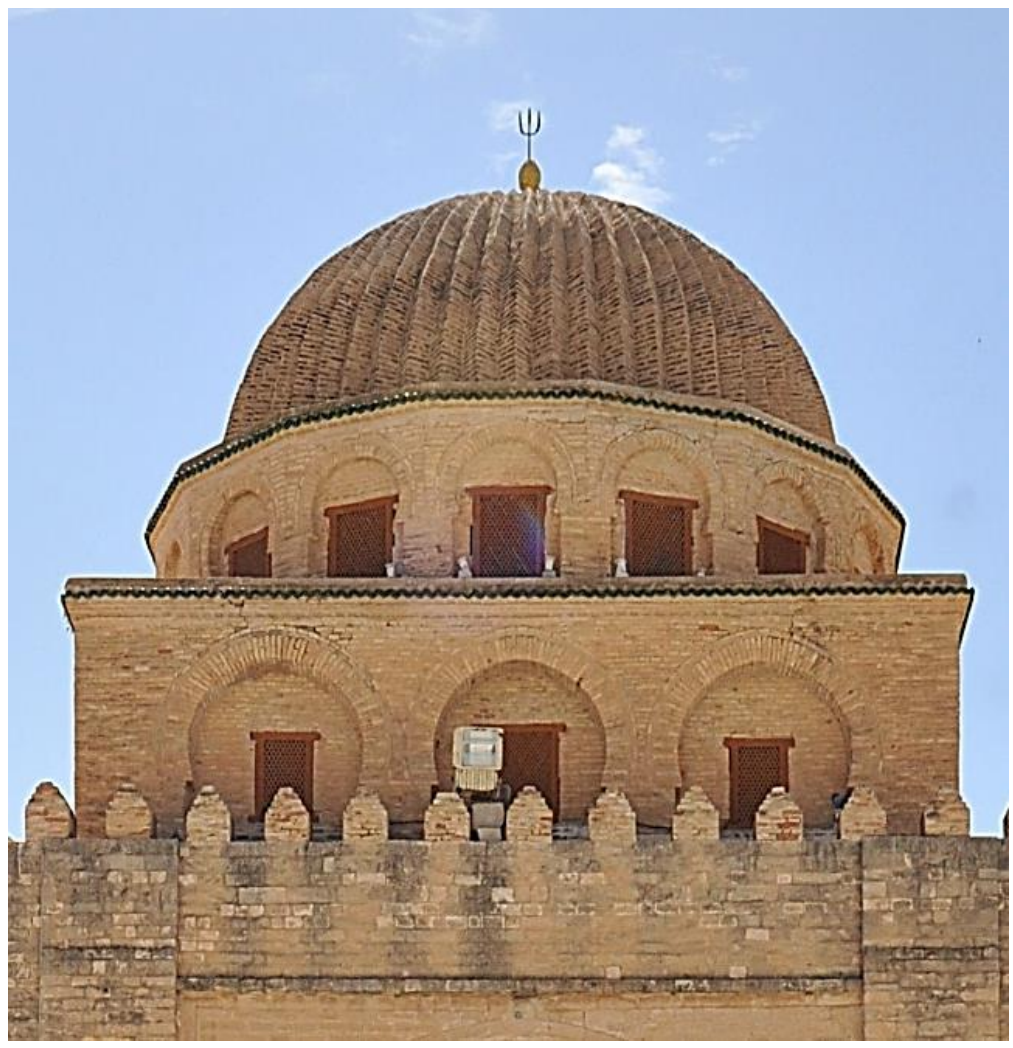

Figure 6: Chamber Hall Dome.

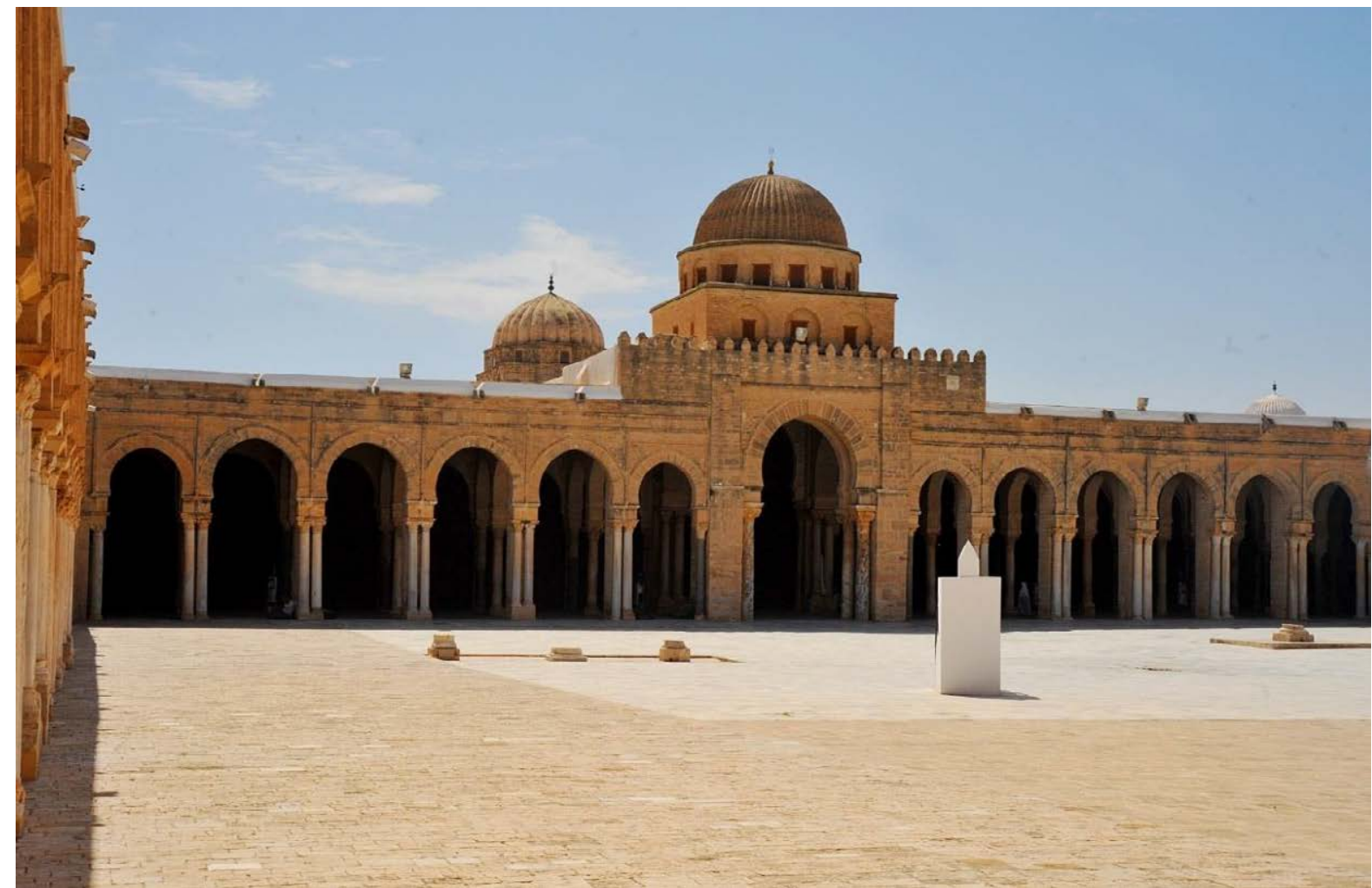

Figure 7: Chamber Hall Dome. Source: Photos by the Author 


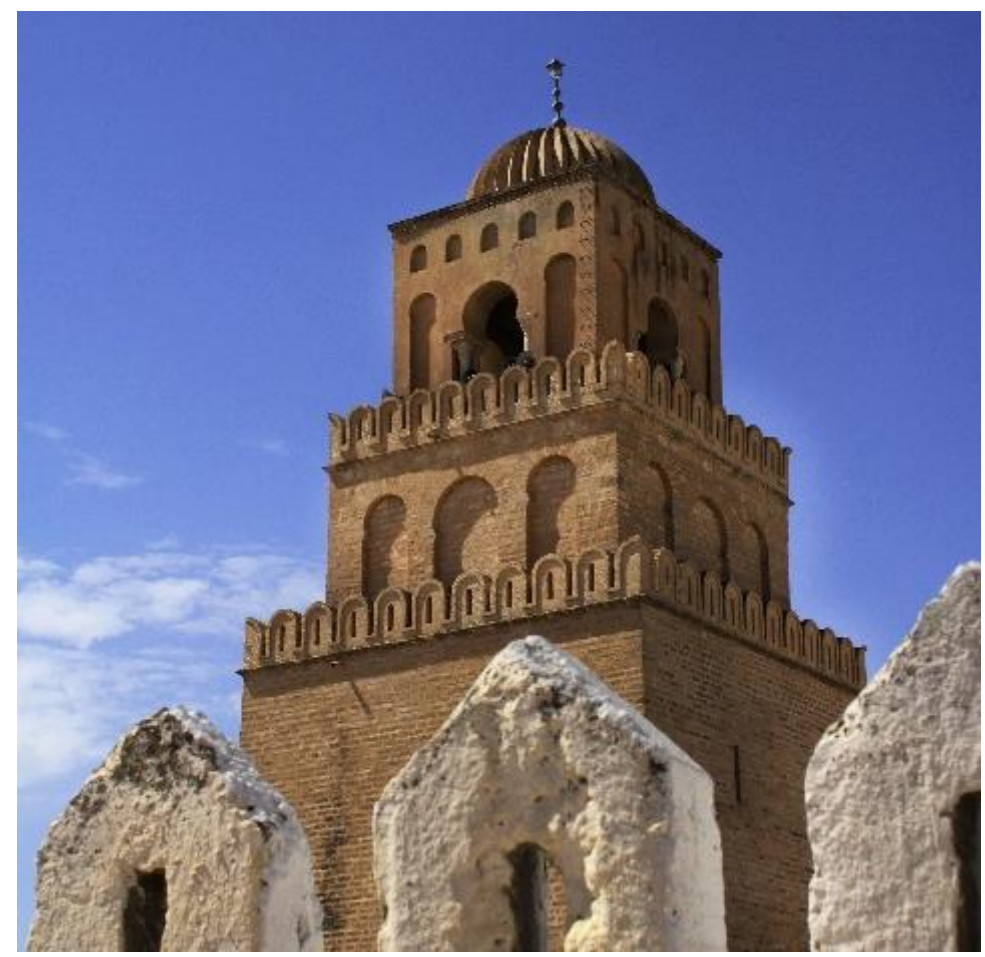

Figure 8: Minaret Dome.

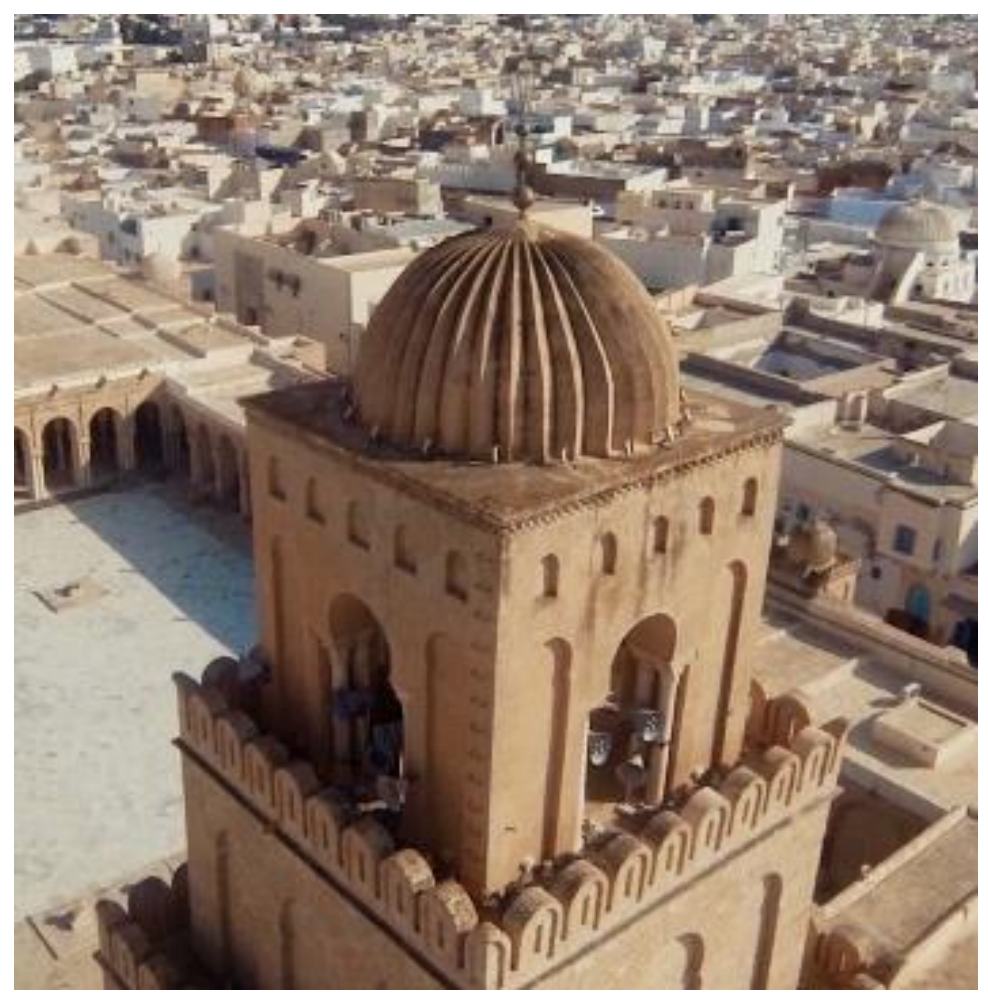

Figure 9: Minaret Dome Exterior View.

Source: Photos by the Author 


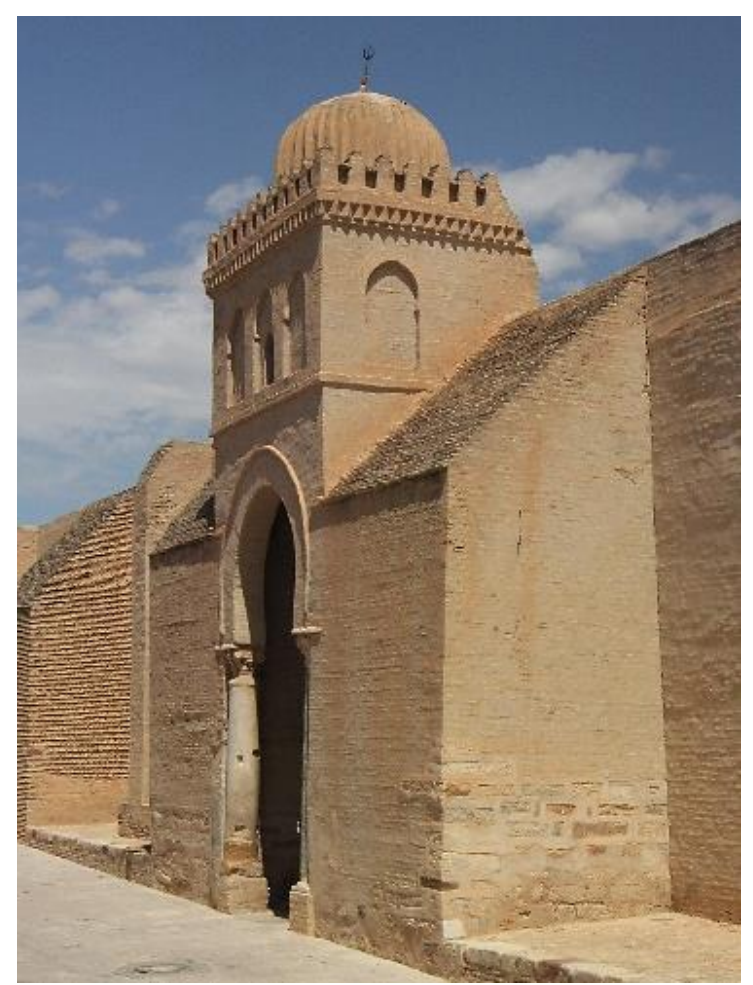

Figure 10: Entrance Dome

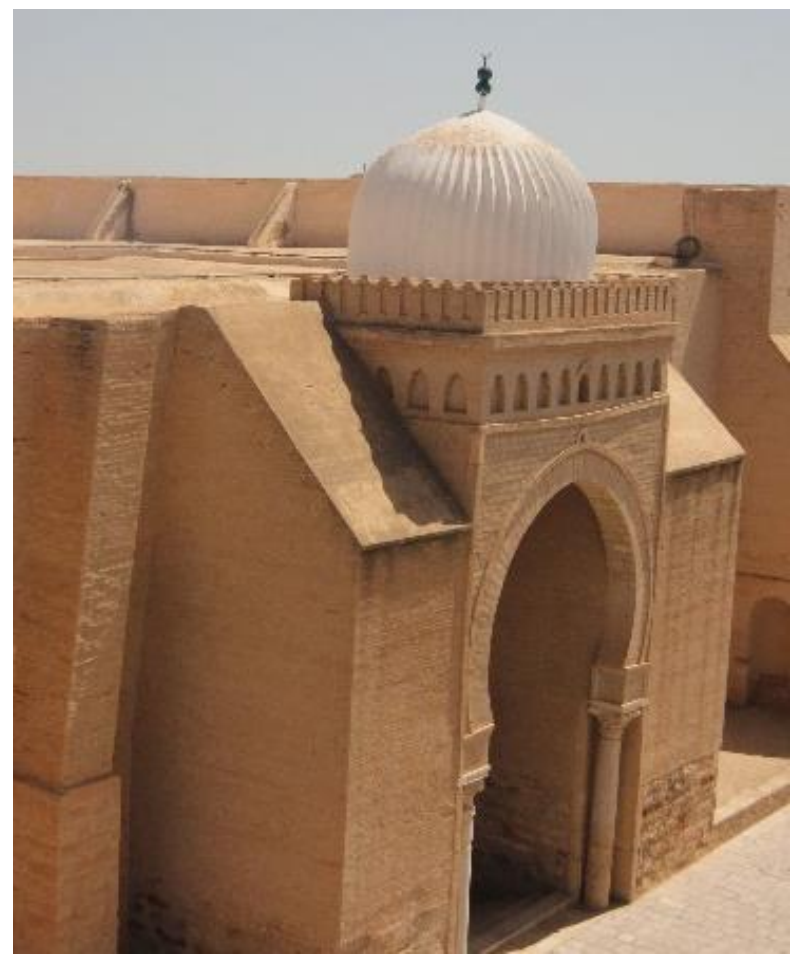

Figure 11: Hafsid Entrance Dome Source: Photos by the Author 


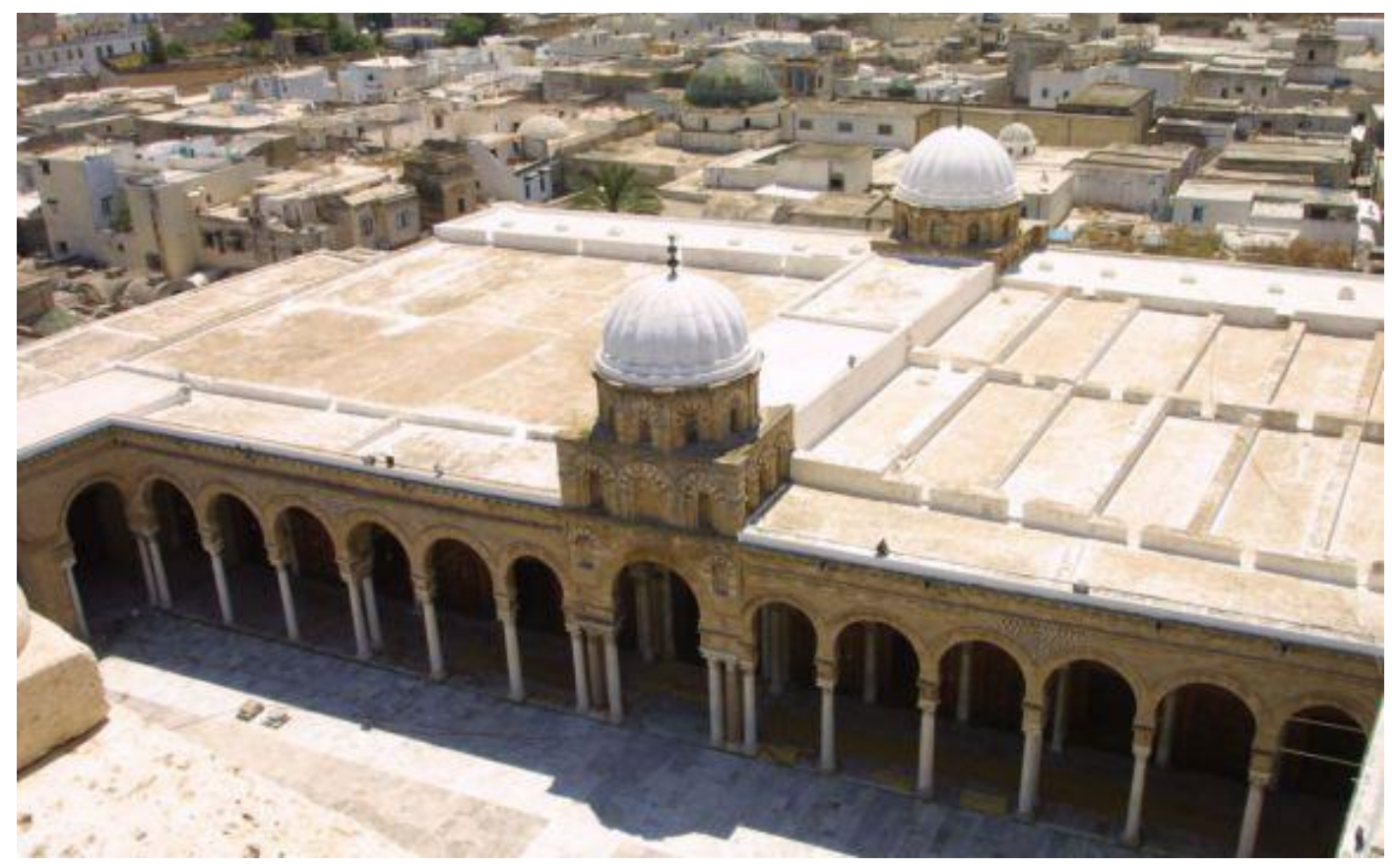

Figure 12: Zaytuna Court with Chamber Hall View.

Source: http://www.discoverislamicart.org/

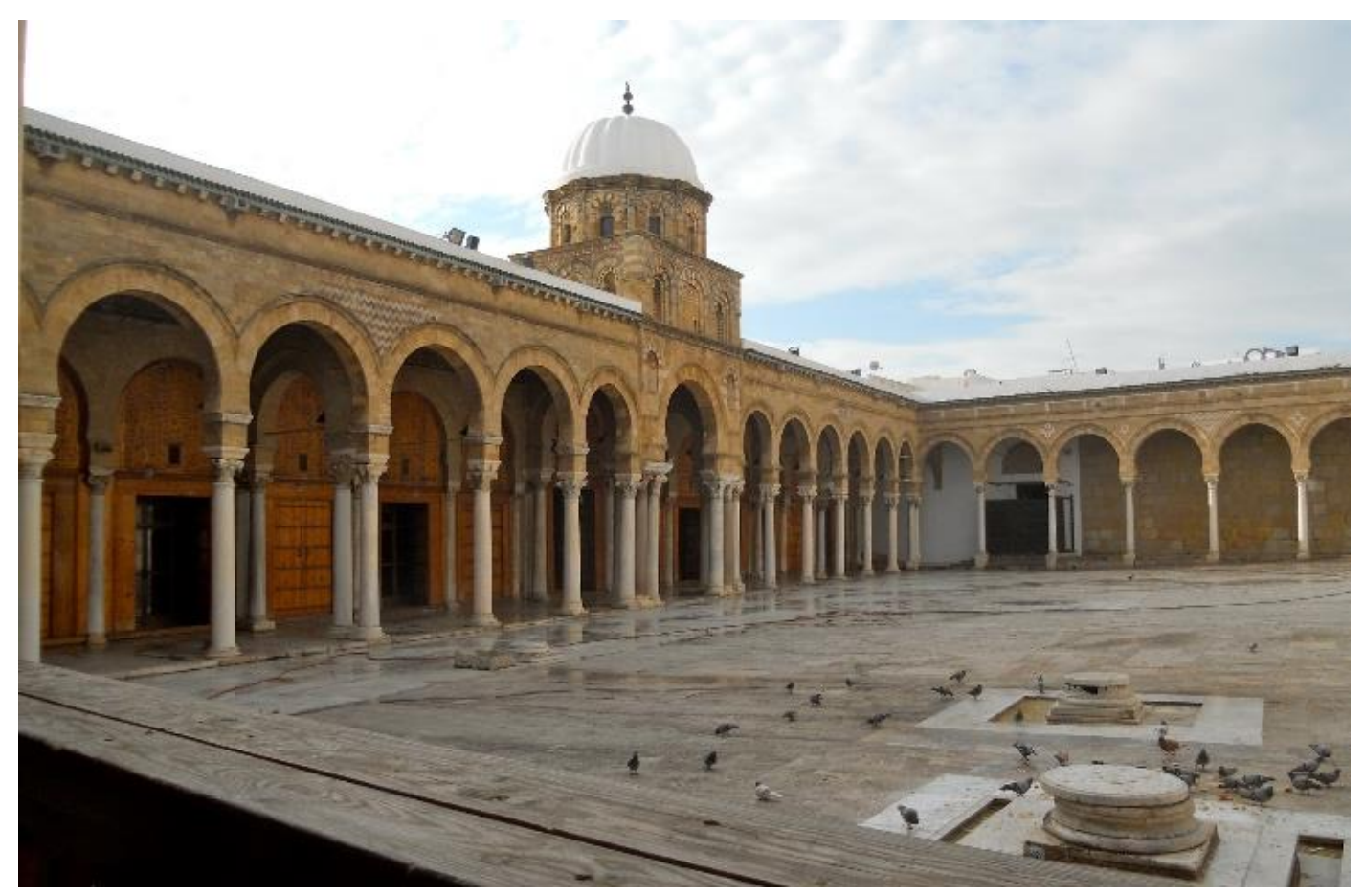

Figure 13: Zaytuna Chamber Hall.

Source: Photos by the Author 


\section{b. Field Trip: Spain}

iii. Cordoba: The Great Mosque of Cordoba

iv. Almeria: The Great Mosque of Almeria

v. Toledo: Cristo de la Luz

vi. Zaragoza: Ja'fariya Palace

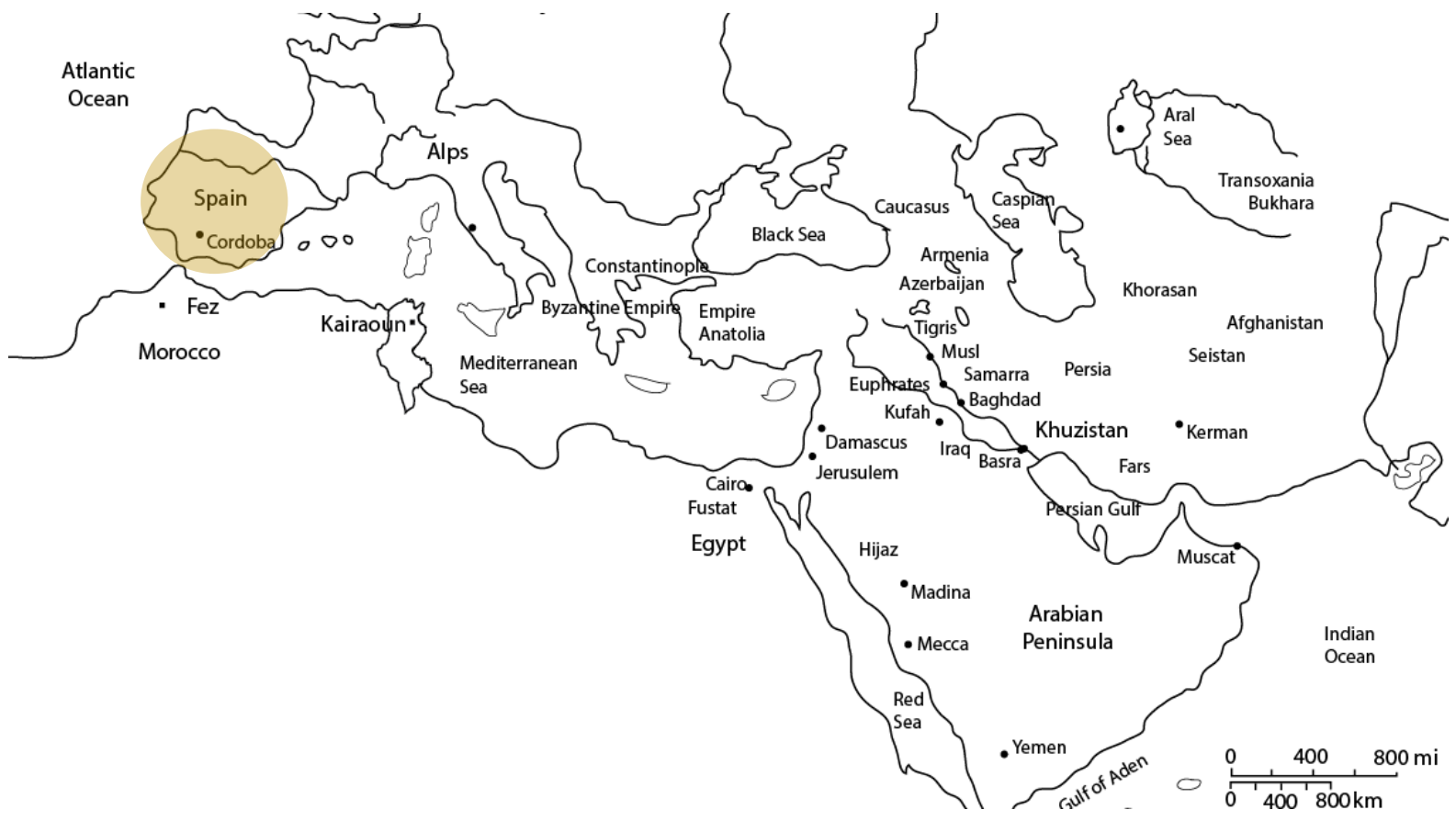

Figure 14: Trip to Spain 


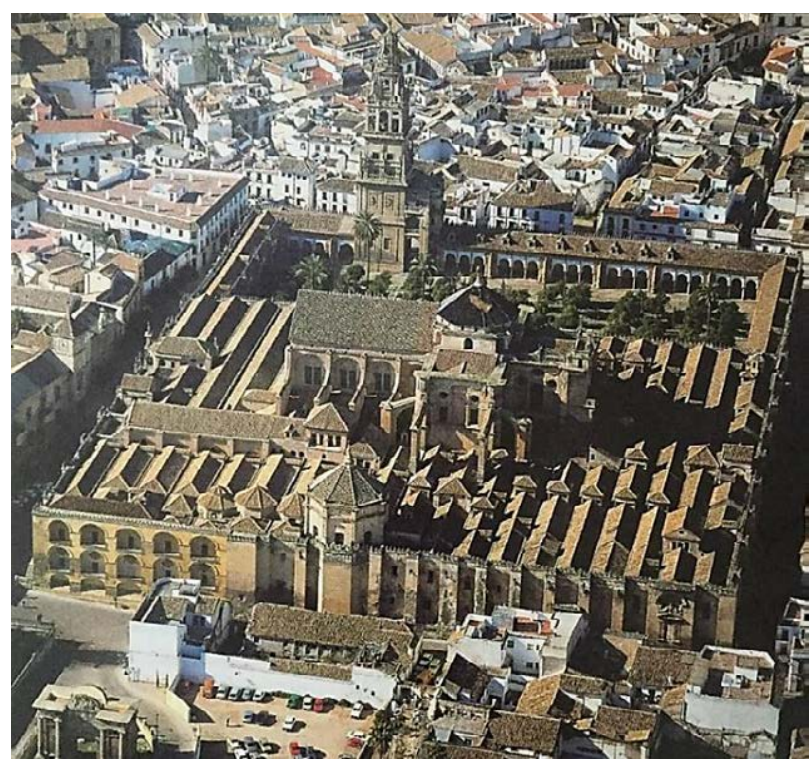

Figure 15: The Great Mosque of Cordoba Top View.

Source: Brigitte Hintzen-Bohlen

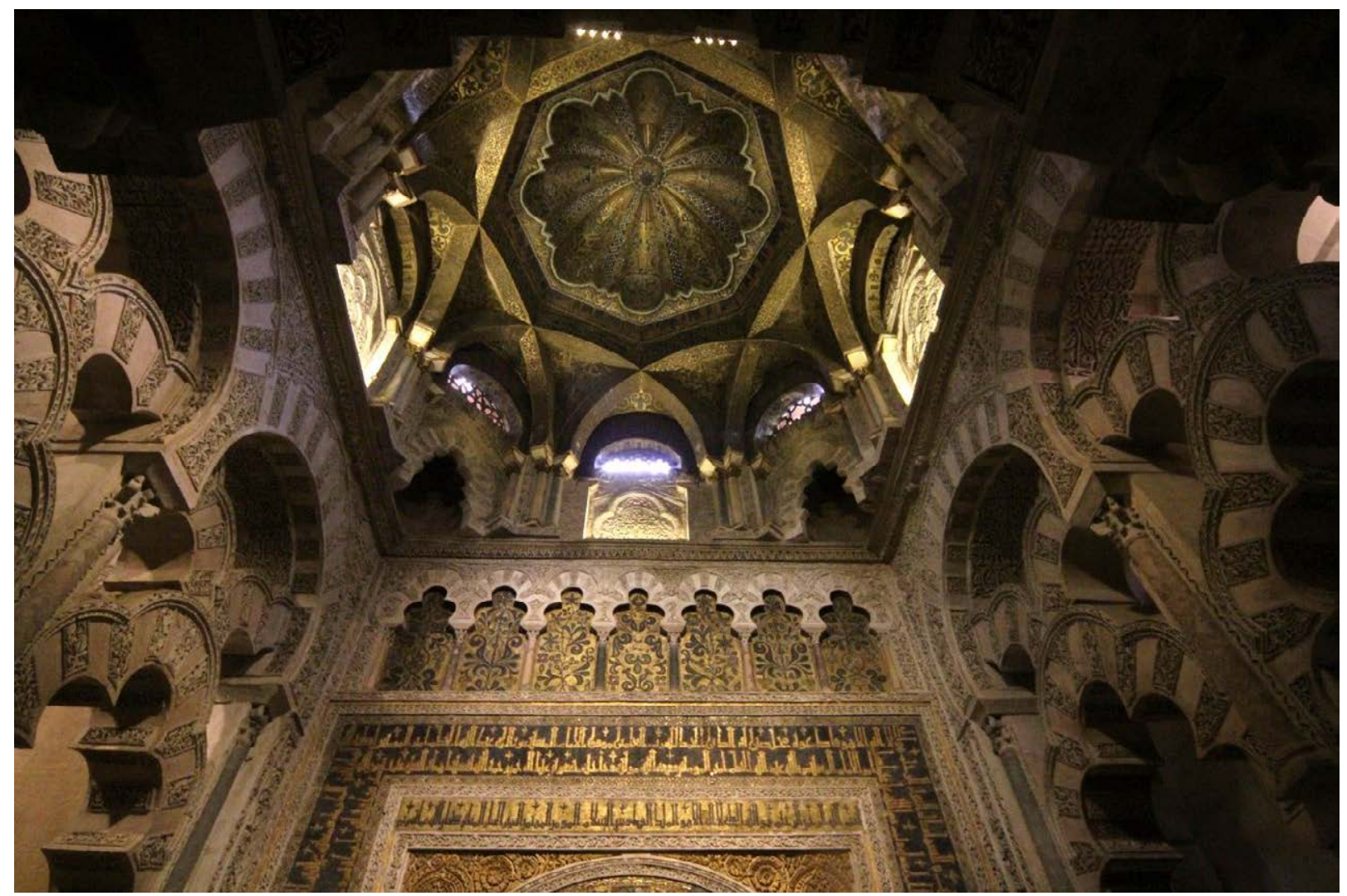

Figure 16: The Center Dome in The Great Mosque of Cordoba.

Source: Photos by the Author 


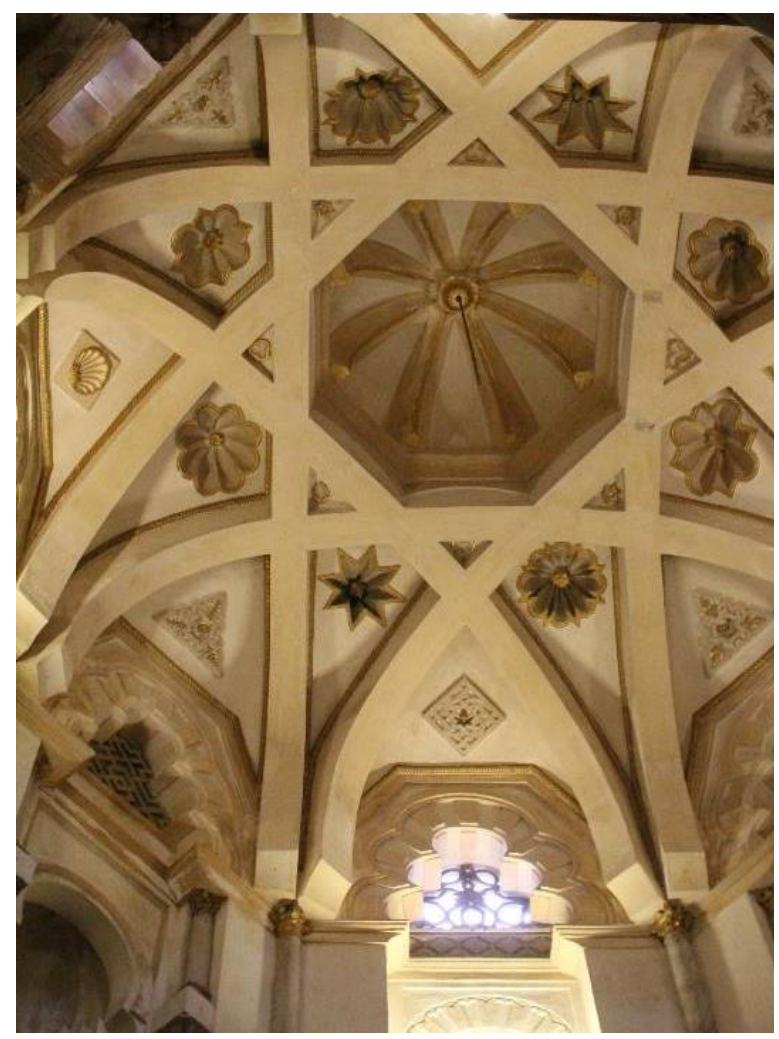

Figure 17: Al Maqsura Cross Vault

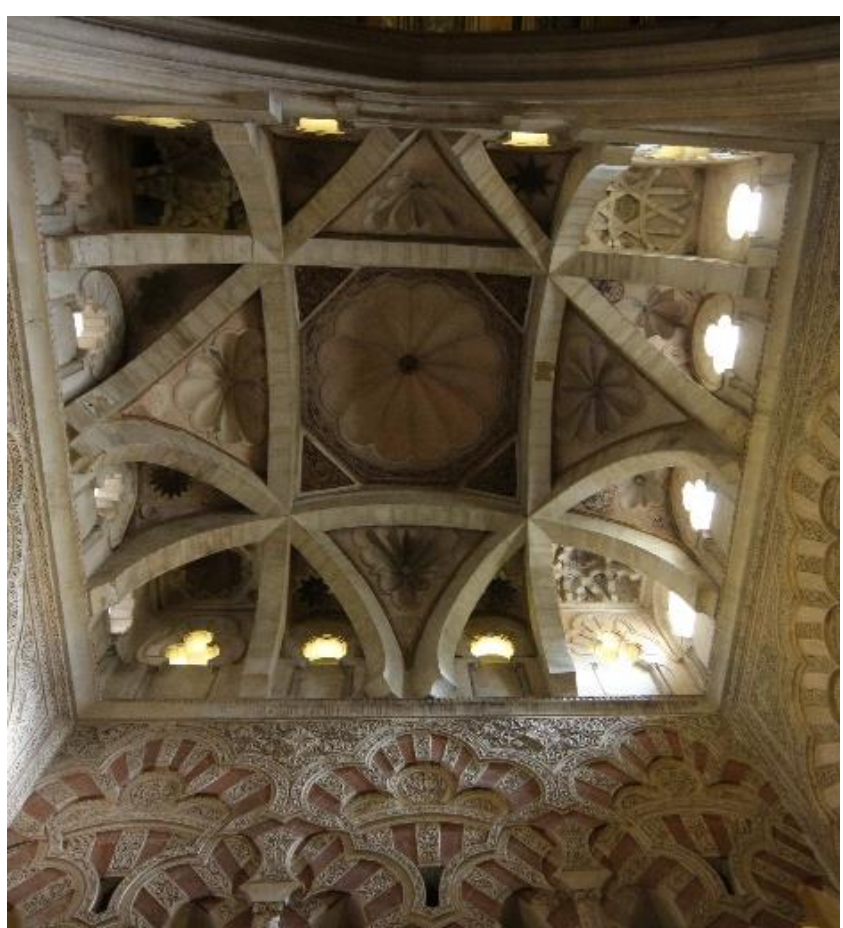

Figure 18: Pre-Maqsura Cross Vault. 


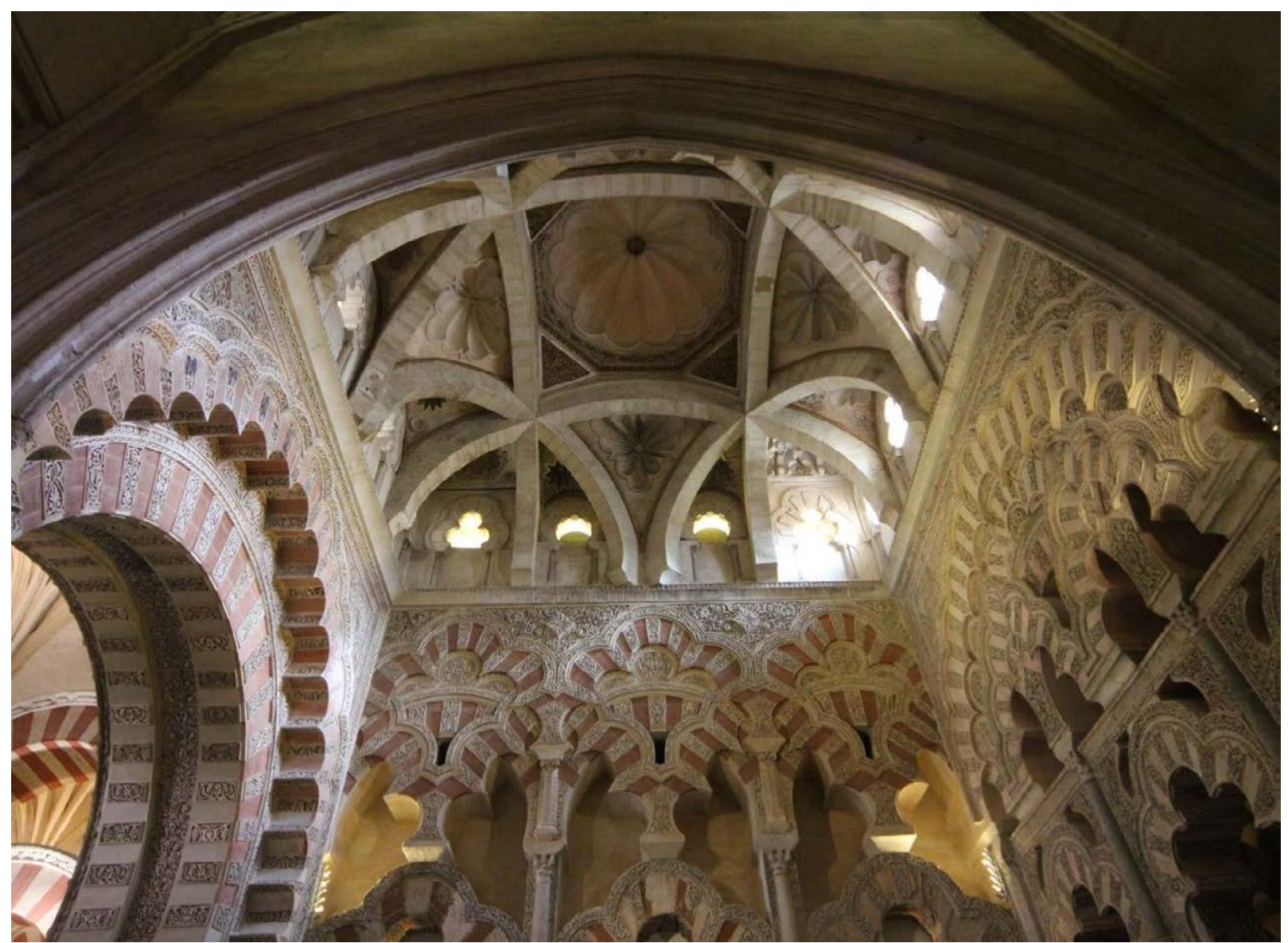

Figure 19: Pre-Maqsura Cross Vault.

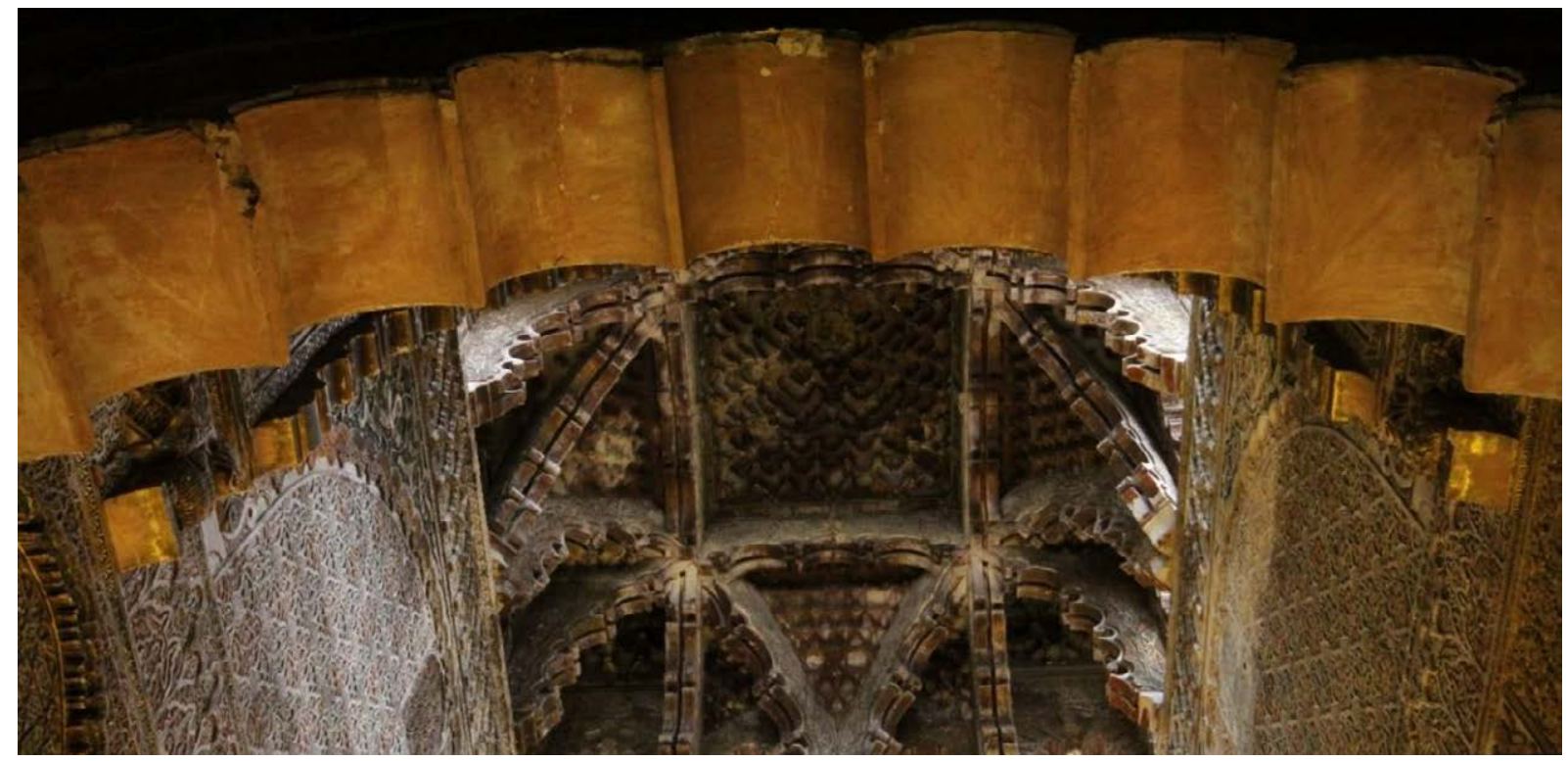

Figure 20: Royal Chapel Cross Vault

Source: Photos by the Author 


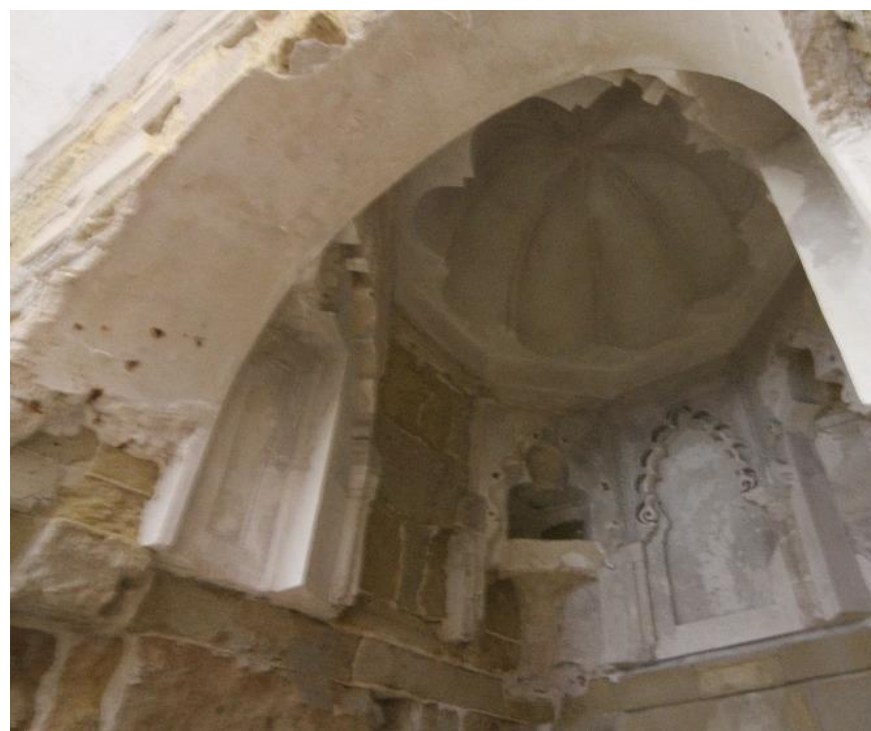

Figure 21: Almeria Great Mosque.

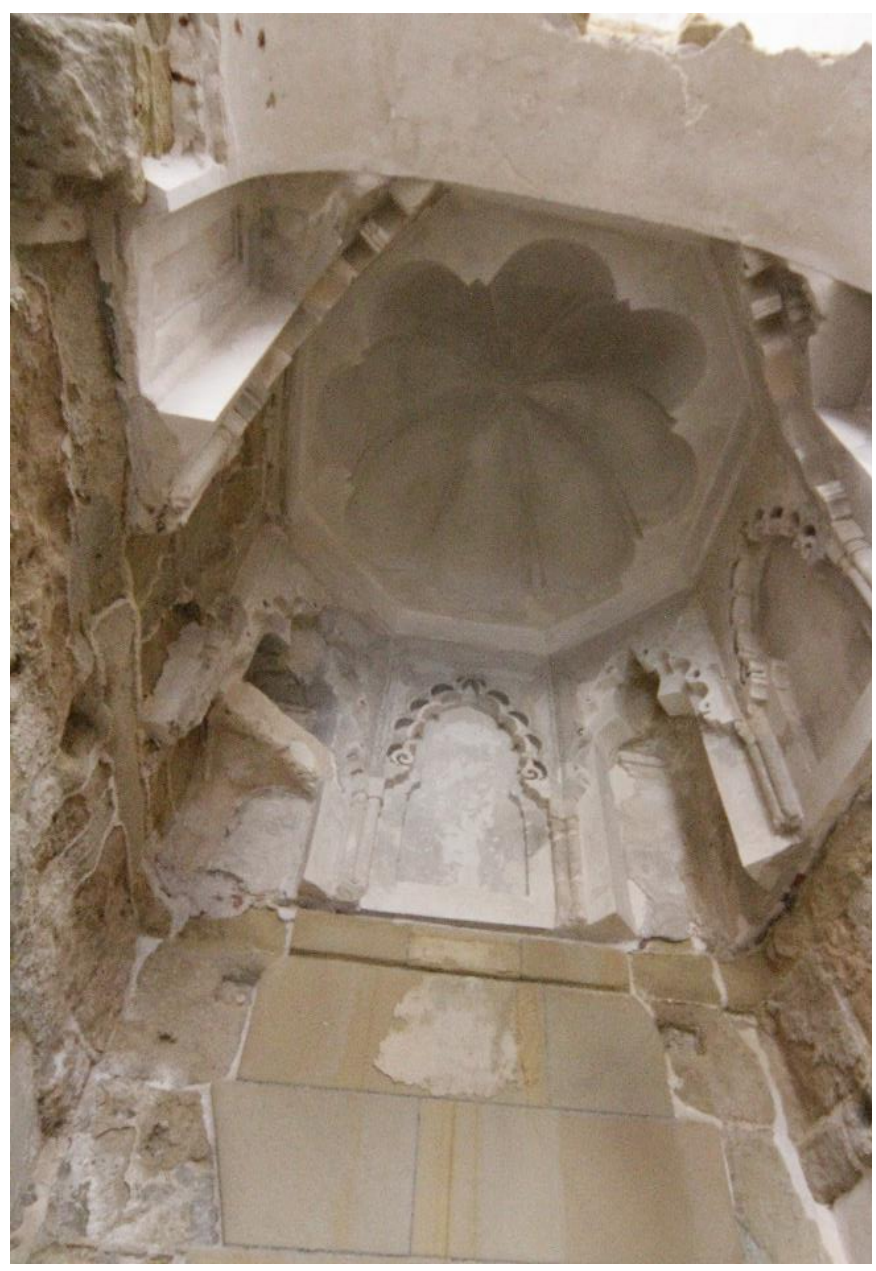

Figure 22: Close shot of Al Maria Great Mosque Mihrab.

Source: Photos by the Author 


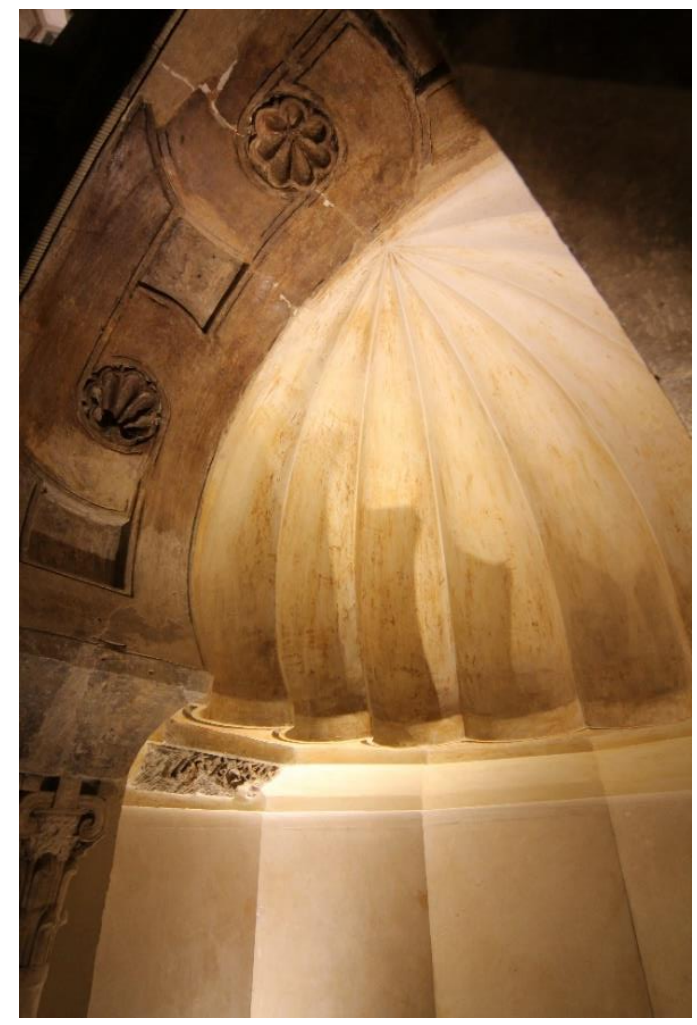

Figure 23: Maqsura Dome.

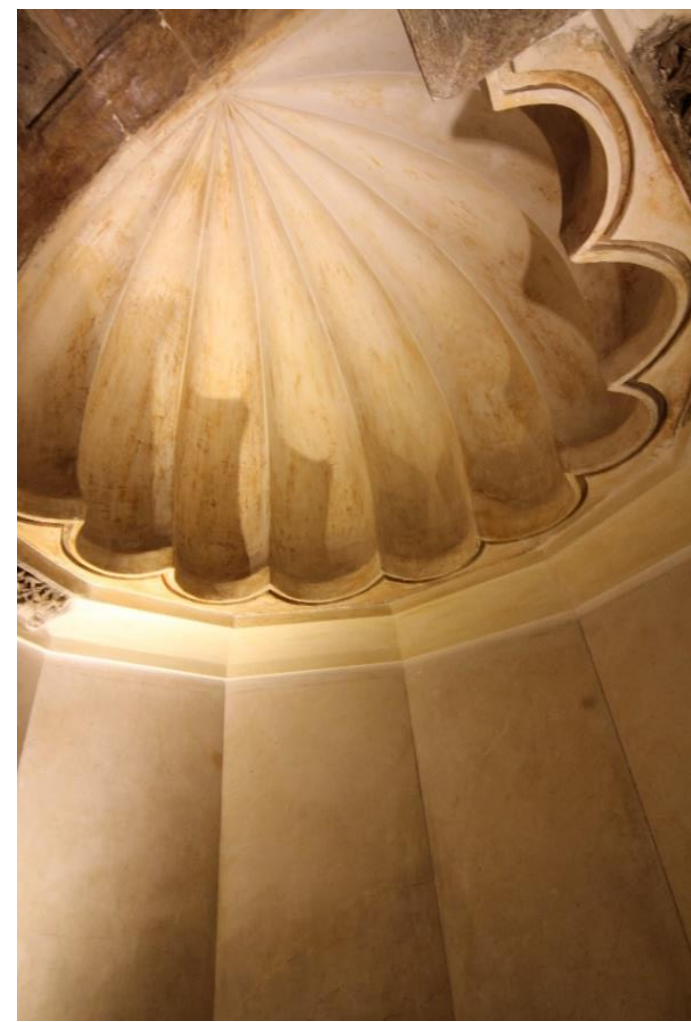

Figure 24: Mihrab Dome.

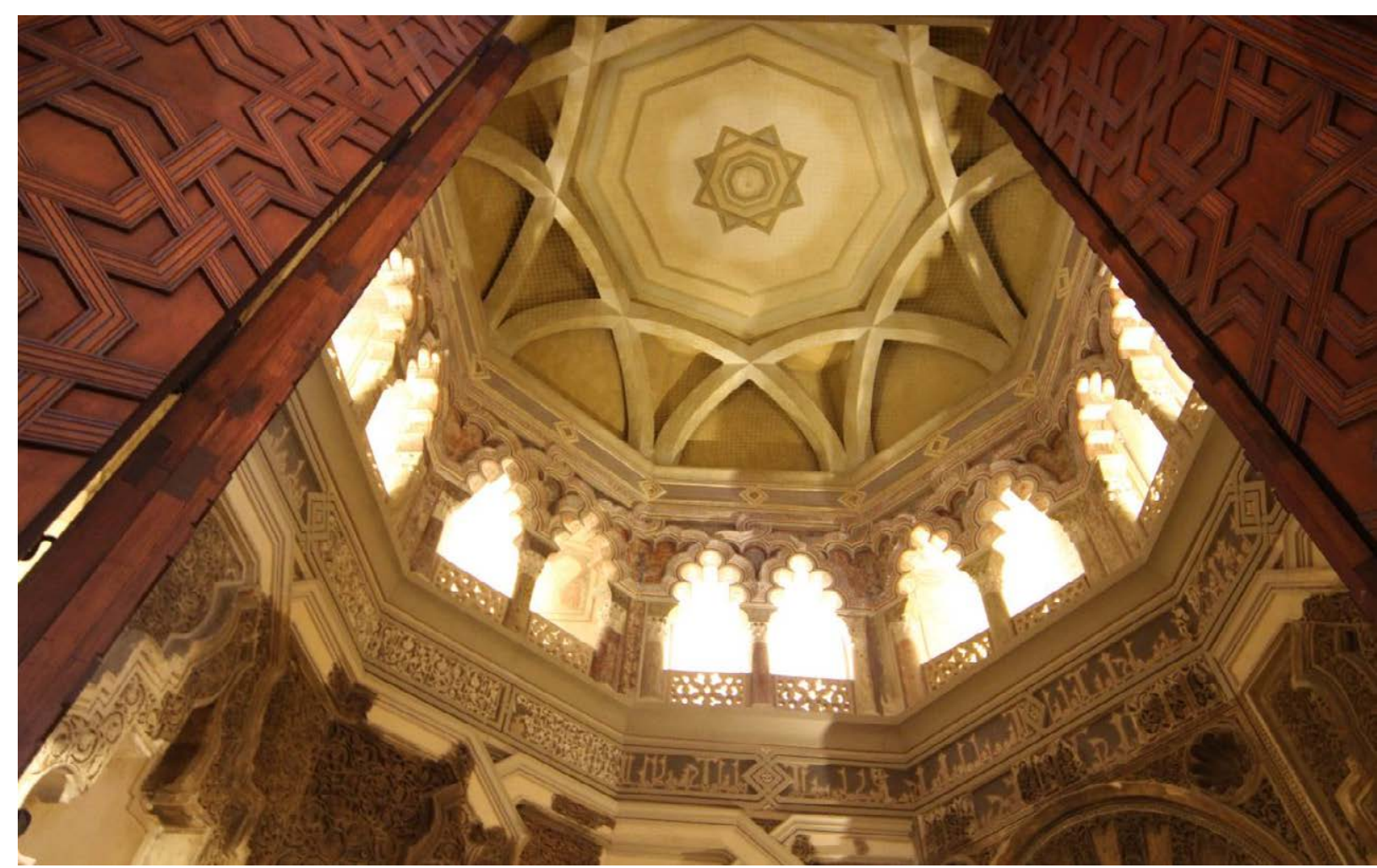

Figure 25: Mihrab Dome

Source: Photos by the Author 


\section{c. Felid Trip: Morocco}

vii. Qarawiyyin Mosque

viii. Andalus Mosque

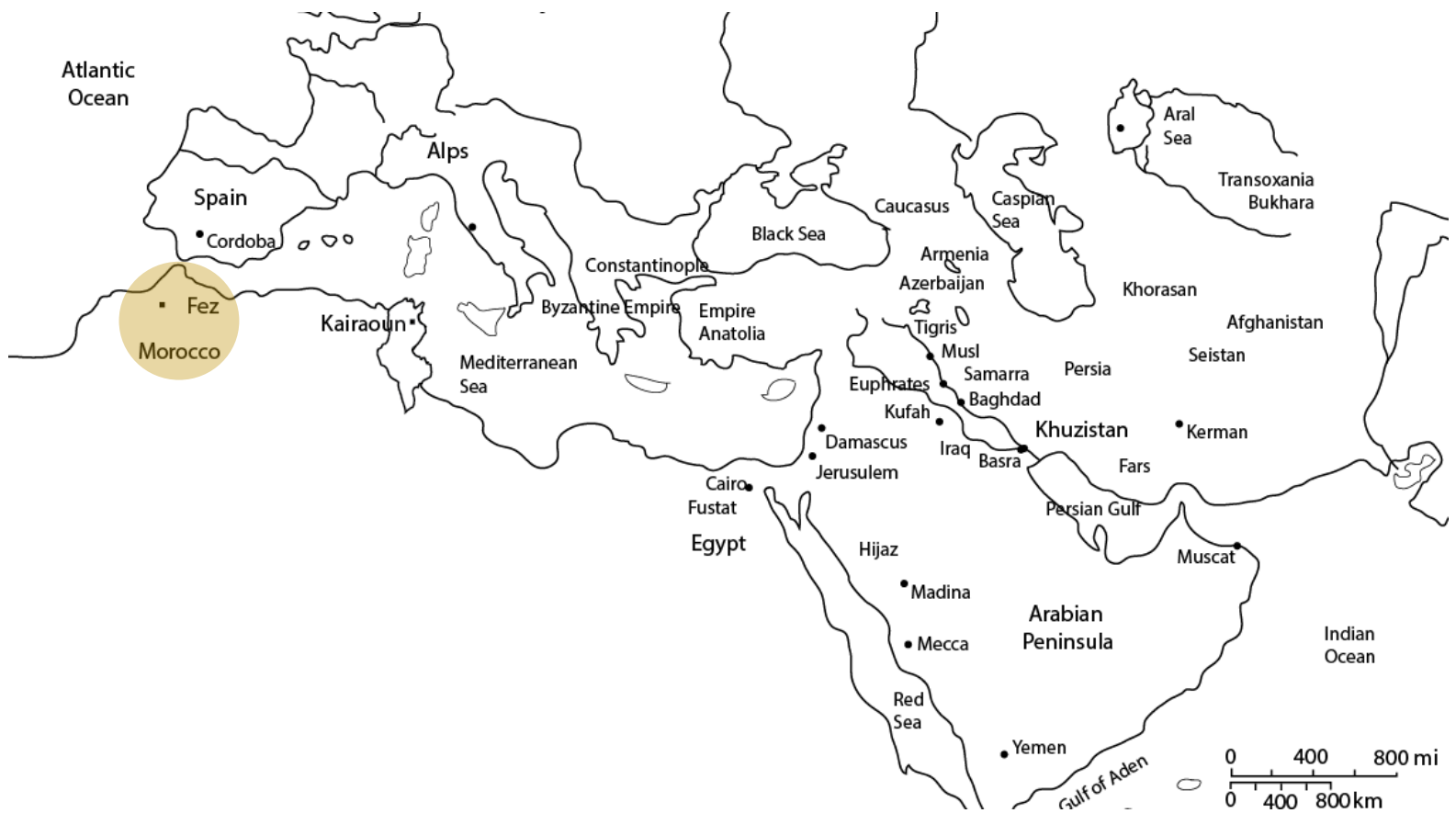

Figure 26: Field Trip to Morocco 


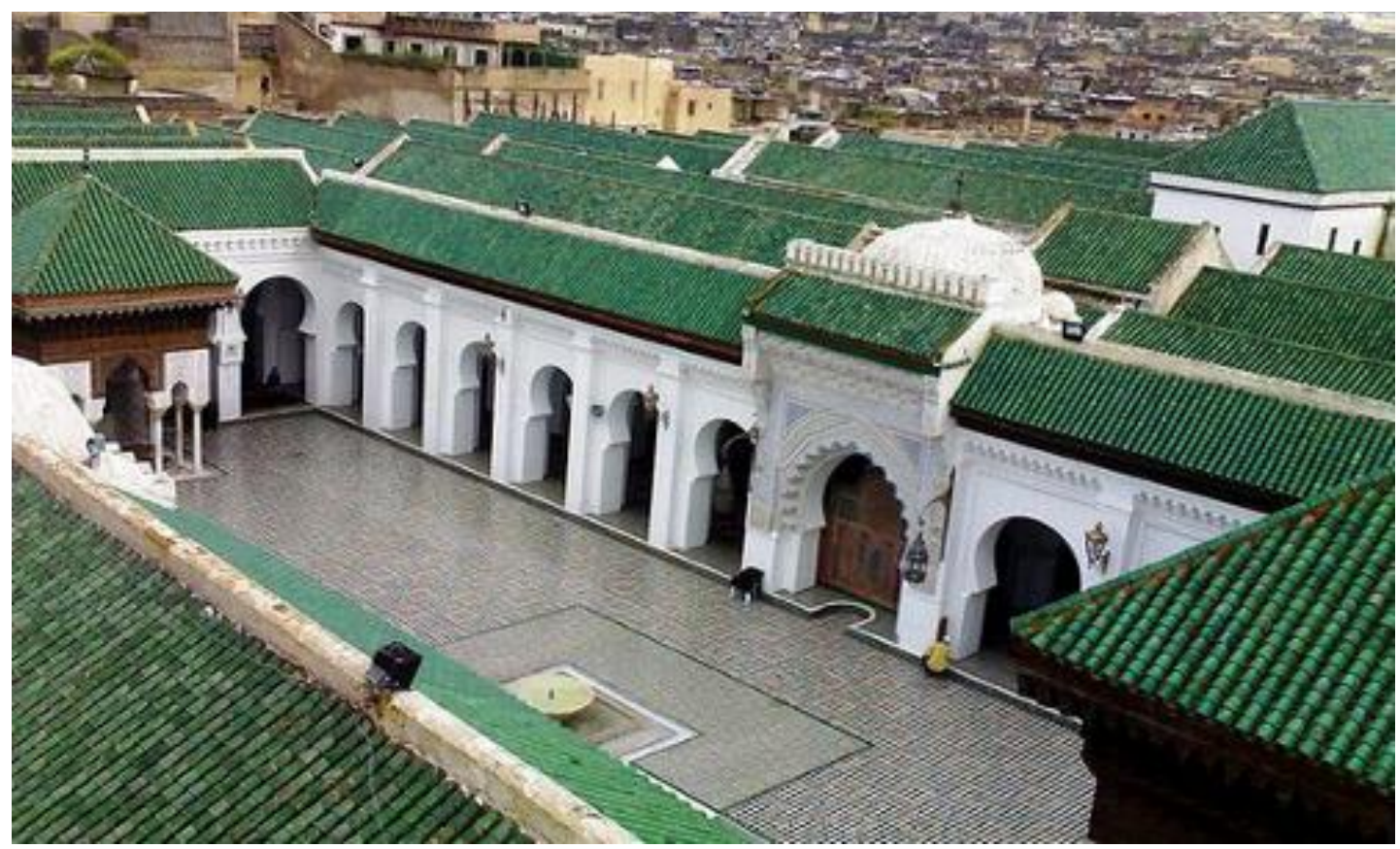

Figure 27: Qarawiyyin Mosque Court

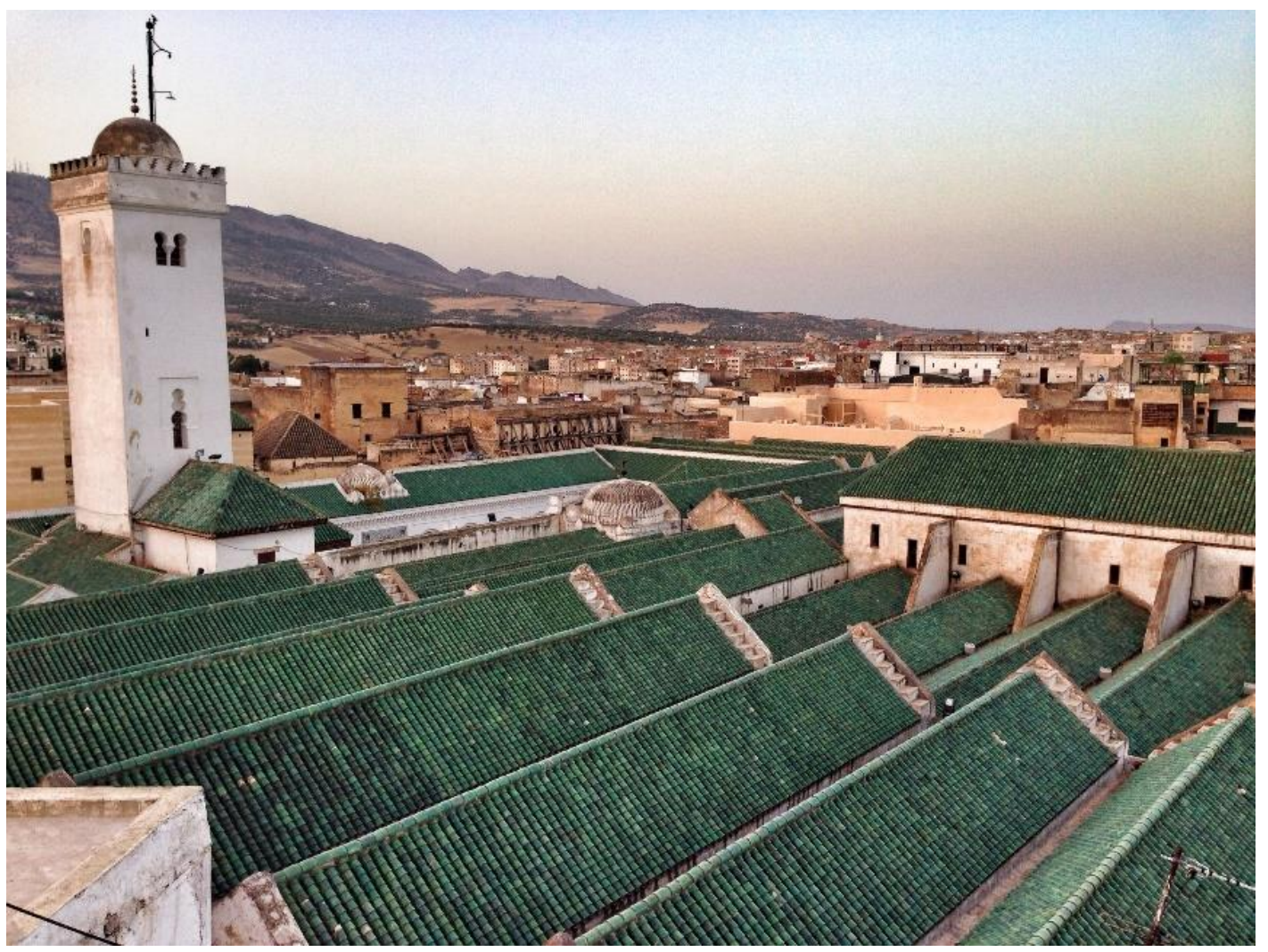

Figure 28: Qarawiyyin Mosque Top View 


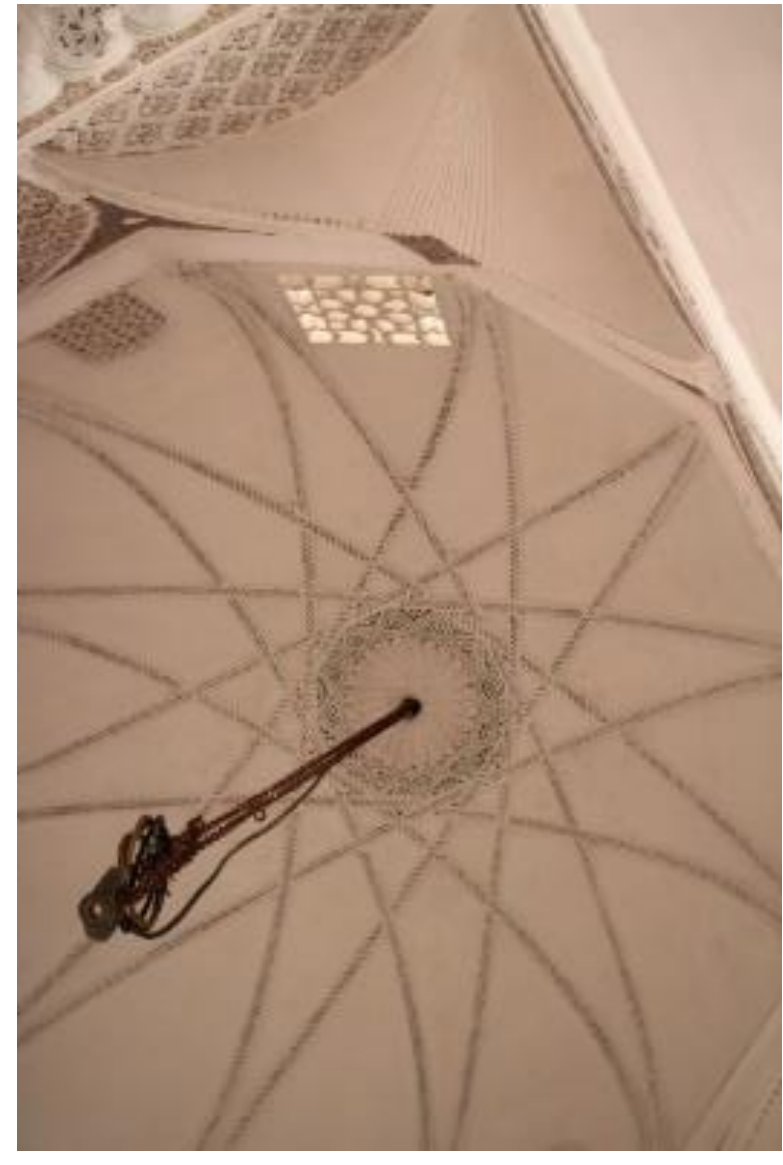

Figure 29: Cross Ribbed Vault

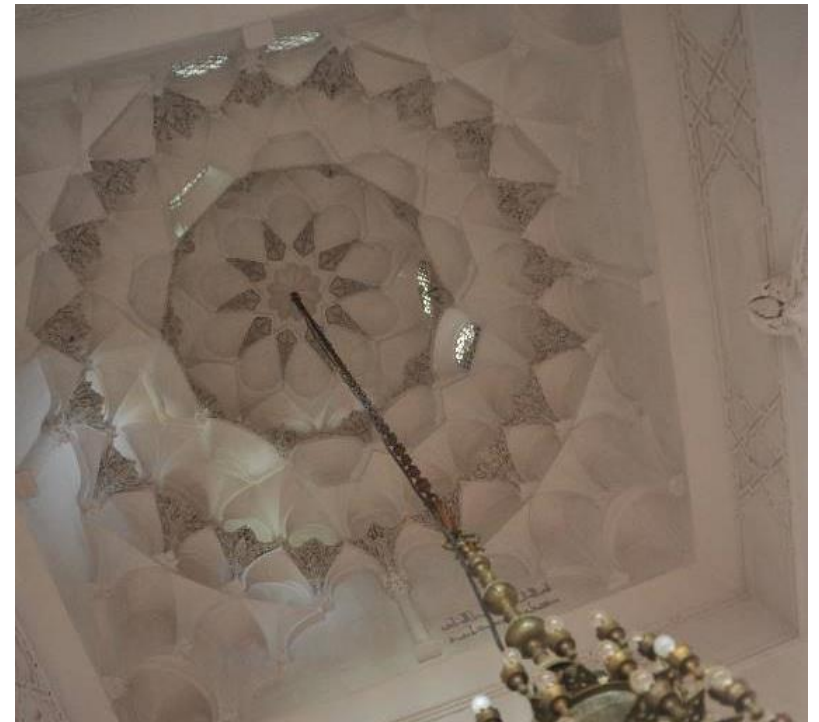

Figure 31: Muqarnas Vault

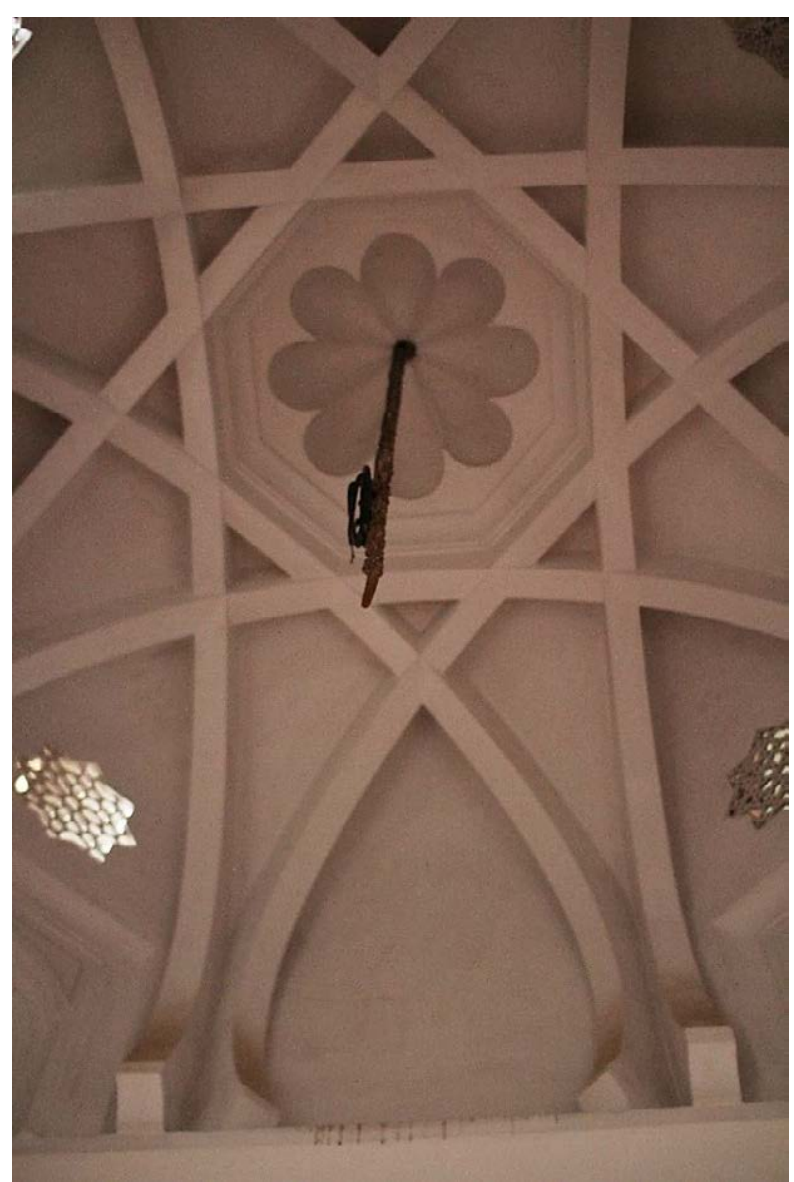

Figure 30: Cross Ribbed Vault

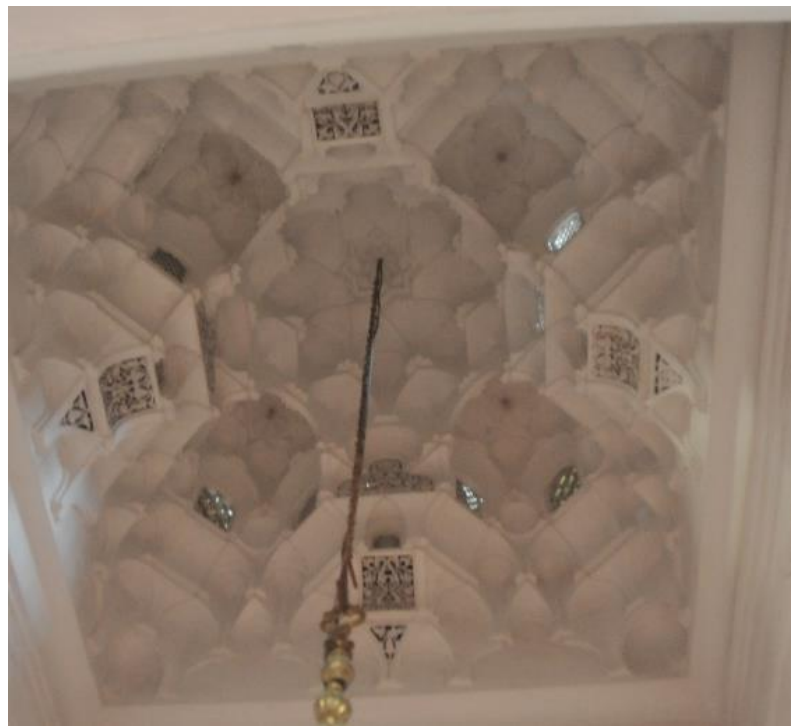

Figure 32: Muqarnas Vault

Source: Photographs by the Author 
P A R T I I

2. THIORATICAL FRAMEWORK 


\section{THEORETICAL FRAMEWORK}

\subsection{STUDY STATEMENT}

The Islamic Ribbed Vaults are significant architectural development structure. However, no comprehensive study has been carried out explaining the origin of the Islamic Ribbed vault. Most research papers had focused on Islamic Iberia's Vaults, Persians, Eastern Europe or Byzantine vaults but there are no papers that had analysed the development of Islamic Vaults since the expansion of Islam until its arrival to North Africa and Spain. Recently, some published papers had studied the Islamic Vaults but they have not analysed the development of the construction methods used in each civilization till it reached Islam. No single paper had examined the relationship between the Islamic Architectural vaults and the vaults of the ancient civilizations, and no study had provided a detailed history of the Islamic Vaults and how they expanded from East to West, or from Central Asia to Islamic Iberia. Studies written by historians briefly reviewed the development of vaults in specific regions but they are not comprehensive studies. This paper provides a clear vision of the birth of the Islamic Ribbed Vaults. It examines the beginning of the Islamic vaults revolution aligned with previous architectural revolutions. The study builds on the work of earlier scholars, European, Iranian and Arabic. However, this paper goes beyond the current available studies. Ribbed vaults in Andalusia are unique architectural elements. The extensive development of these vaults started in the tenth century. The intersection of the ribs arches forms a polygon, which makes differences in structure than early Islamic Vaults. In Islamic Iberia, crossed-arch domes form a polygons in the center. These structures are different from the earlier vaults built in North Africa. There has been a great deal of debate between scholars about the origin of ribbed vaults; different hypotheses are discussed in different papers. Although Khwarizmi ${ }^{2}$ had established the mathematical principles of geometry in Central Asia, but the Architecture based on construction geometry had been used in Islamic Iberia from earlier times the his studies. This is one of the factors that has created so much debate

\footnotetext{
${ }^{2}$ Who initiated the since of geometry, 780-850 AD
} 
about the origin of Islamic Ribbed Vaults. Geometry had been used in brick facades decorations in Central Asia, but geometry in domes began in Spain hundreds of years before.

Manuel Gomez Moreno, a Spanish archaeologist and historian, who wrote a Book named: Monumental Catalogue Spain artistic and Monumental. His Book was a source for scholars' studies [1].

Fernando Villasenor Sebastian in his paper: The importance of Monumental Catalogue on investigating the medieval art in Spain align with George Marcais, the French historian had supported the theory of Cross Arched Vaults originated from Persia [2][3].

While Ricardo Velazquez Bosco, a Spanish architect, archaeologist and scholar who had carried out restoration work on the Great Mosque of Cordoba in 1910 -1911 AD had suggested the possibility that these domes are masonry interpretation of timber domes constructed in Central Asia neighbourhoods, recognised by hole in the centre of the dome for fume extraction purposes [4]. Vicente Lamperez, a restoration, architect and historian of Spanish art had supported the theory of Ricardo Velazquez Bosco while Dr. Joel Meunie and Henri Terrasse, believes that the origin of the arch vaults on squinches are originated from Mesopotamia, but After Godard's theory Henri Terrasse had supported him on the theory of Persian origin [5] [6 [7] [8] [9].

Brigitte Hintzen Boheln in his book: Andalucia: Art and Architecture classified the Islamic Vaults by the Caliphates and their periods [10]. Paula Fuentes and Santiago Huerta in their research paper: Islamic domes of crossed-arches: Origin, geometry and structural behaviour discussed that the origin of arched domes initiated was in Spain [11]. Antonio Almagro Gorbea and Alba Soler Estrela in their Survey on Vaults with Inter-crossed Arches had Justified that Al Mohad vaults of intersect arches began in the tenth century in the Great Mosque of
[1] (Moreno, 1951)

[2] (Sebastian, 2012)

[3] (Marcais, 1883)

[4]( Bosco, 1894 )

[5] (lamperez, xx)

[6] (Meunie and

Terrasse, 1957)

[7] (Terrasse, 1943)

[8] (Godard, 1965)

[9] ( Terrasse, 1932)

[10] (Boheln,xx )

[11] (Fuentes and Huerta, 2015) 
Cordoba and had a unique geometrical analysis not founded in al Andalus nor North Africa, showing the enormous creative capacity of the architects designs with geometry [1].

[1] (Gorbea and

Carlos Gobea described the Vaults in Marrakesh and Seville, Estrela, 200x) which are distinguished by their fine arches built of bricks [2]. On [2] (Gorbea, 200x) the other hand, Luis Ferre de Merlo in his paper: Ribbed Vaults in Villena Castle explained the Quadrilateral plan of the arched domes famed in Spain were brought to the Iberian Peninsula by Muslim invaders from Persian [3]. Ferre added that the [3] [4] (Merlo, 2000) constructions of ribbed domes used in Spain started in the tenth century [4]. Alireza Anisi in his Ph.D. thesis 2007, had studied the Early Islamic Architecture in Iran from 637 until 1059 considering all type of mosques built since Islam arrived to Iran. He included the Persian monuments that are not introduced to Islamic Architectural to examine the evolution of Iranian architecture in this period [5]. Andre Godard a French archaeologist architect and historian of Middle Eastern Art with Henri Violle [5] (Anisi, 2007) together excavate the ancient ruins of Samarra in Iraq describing their architecture methods and contribution to History [6] [7]. A few years later Ernst Herzfeld gave further investigations [8]. Andre Godard had the change to be involved in the restoration of major historic monuments in Iran, such as the Friday Mosque, the Shah Mosque and the Mosque of Sheikh Lutfallah of Isfahan among others and had a better understanding of more methodologies in Iran [9]. In 1876, Auguste Choisy, an architectural historian and author of History of Architecture published a book [10]: Note on the Construction of Vaults without [10] (Choisy, 1876) Centering during the Byzantine Period, where he made major

[6] (Godard, 1965)

[7] (Violle, $x x)$

[8] (Herzfeld, 1942 )

[9] (Godard, 1949 ) 
analysis on vaults without centring construction methods. The book had an enormous impact on the history of Byzantine architecture that will be explained in Part III of this research study. In 1883, Choisy had published: The art of Building in Byzantine, which contains theories of historical methods in building and made a clear explanation of the Byzantine geometrical methods used in vault construction methods [1]. His study suggests that all circumstances

[1] (Choisy, 1883) of construction are derived from the nature of byzantine vaults. There are other scholars who had wrote on the history of vaults and supported Choisy's studies such as: Roland Besenval in his book: Technology of the Vault in the Ancient East Orient, and Jan Cejka a German Architect that supported the same studies in his book: Barrel Vault Ceiling and Arches of Islamic Architecture [2] [3].

Storz in his book: The Art of Building in Byzantine, believed that the [2] (Besenval, $x x)$ [3] (Cejka) best source for geometry, construction and structural behaviour are Byzantine vaulted buildings [4].

[4] (Storz, xx)

Lynne C. Lancaster in his book: Innovative Vaulting in the Roman Architecture Empire: 1 st to $4^{\text {th }}$ centuries had described the types of vaults made of bricks and the vaults forms developed since preRoman [5].

[5] (Lancaster, xx)

Santiago Huerta, a Spanish professor in History and a Researcher in Construction, had studied Choisy's theories in a research paper tilted: The geometry and construction of Byzantine vaults: Fundamental Contribution of Auguste Choisy explaining: [6]

[6] (Santiago, 2009) Bryan Ward-Perkins an Italian archaeologist and historian of the later Roman Empire and early middle Ages had new visions with criticism to the geometrical theories of Choisy's Byzantine vaults [7].

[7] (Perkins, xxx) 
Giovanonni had wrote a detailed description of the use brick ribs in vaults construction.

[1] (Giovanonni, xxx)

Nikolaos Karydis in her research paper: Limiting the Use of Centering

[2] (Karydis, xx) in Vaulted Construction: The Early Byzantine Churches of West Asia Minor described the early stages of vault developments in the late fifth century until the seventh in Byzantine Churches of West Asia Minor.

Jurgis Baltrusaitis, presented the differences and similarities between

[3] (Baltrusaitis, xx) Armenian and Islamic vaults. He believes that ribs only carry structural function in Armenian vaults, while in those of Islamic origin are merely decorative. He also mentioned that these ribs have geometrical patterns forming ornaments.

Gomez Moreno proposes a possible of Mesopotamian origin and [4] (Moreno, xx) Galdieri supports this theory [4] [5].

[5] (Galdieri, 1981)

Pavon Maldonado wrote about a possible origin of Roman antiquity. Giese Vogeli tackles briefly the matter of the structural behaviour of crossed arch domes, mainly with reference to the Gothic debate.

[6] (Maldonado, $x x$ )

[7] (Vogeli, xx)

Santiago Huerta titled as: Essays in the History of the Theory of Structures in honour of Jacques Heyman explained the whole debate of the function of the rib supposition that there is an actual observable of the structure [8]. Heyman cleared that the theories on the origin of the cross-arch vaults had started in the VIII - X century demonstrated the Great Mosque of Cordoba with a great level of complexity and perfection.

[8] (Huerta, 2010) Lambert had pointed that the vaults of the Great Mosque of Kairouan was built in $836 \mathrm{AD}$ and in Al Zaytuna Mosque in $864 \mathrm{AD}$, both are [9] (Heyman, 1968) influenced with the Vaults of the Great Mosque of Cordoba [10].

[10] (Lambert, 1928) 
Besides, recent constructive studies done

By Galdieri made on ribbed Persian domes has demonstrated that the thinness of the arches is only apparent, as the ribs project to the outside of the extrados [1].

Paula Fuentes, and Santiago Huerta had described in their research paper: Crossed-Arch Vaults in Late-Gothic and Early Renaissance Vaulting: A Problem in Building Technology Transfers: Crossed-arch vaults are a particular type of ribbed vaults. Their main feature is that the ribs that form the vault are intertwined, forming polygons or stars and leaving an empty space in the middle [2]. In Gothic architecture, there is wide agreement that the ribs serve to define the geometry of the vault and form a permanent centring during construction. The whole matter of the structural behaviour of Islamic vaults and domes has been so far neglected. This is curious as some scholars:

Lambert, Torres Balbas and Pope, beliefs the very origin of the Gothic rib in the earlier crossed-arch domes [3] [4] [5]. To gather together the different sources in Arabic, French, German, Spanish, Arabic and Persian was a challenge and an important aims of the study. The primary aim is to understand the characteristics and the underlying principles of early Islamic Vaults. It documents the earlier experiments in building types, structural techniques and architectural decoration. The thesis tries to explain how the heritage of pre-Civilization architecture evolved and how it laid the foundations for Islamic Architecture, especially Umayyad, Abbasid and Seljuk architecture. Thus, to create a solid base for studying the later period is an important supplementary aim to this research study. Debated on the structure of ribs, distribution of loads, and weather ribs are used for decorative purposes or part of the dome structures. Arabian scholars had carried out architectural and archaeological research; some has not been published yet while others has been published but need to be translated and this paper introduces and translates these works.
[1] (Galdieri, 1981)

[2] (Fuente and Hertam, 2010)

[3] (Lambert, 1928,

[4] (Balbas, 1935)

[5] (Pope, 1963) 


\subsection{LITERATURE REVIEWS}

A comprehensive Theoretical Framework of Arabic, English, Persian, French and Spanish in the field of Islamic Architectural history and the development of vaults before and after Islam until its arrival into North Africa and Spain is taken into account. Previously, researchers and scholars had investigated on the Islamic architectural Ribbed Vaults origin with different results. A theoretical study of previous scholars in different sources is explained in this part.

In the book: The Birth of Civilizations written by group of scholars.

Robert had mentioned:

'The geographical expansion does not carry the detailed civilization. Art cannot be applied in a second or as a magic. The time element is necessary’ (Robert, 1958) P. 10

Oleg Grabar in his book: The Formation of Islamic Art focuses on the earliest centuries of Islam explored the tradition of Islamic Architecture and in what way it is inherited from Roman, Byzantine and Sassanid's. He described the Islamic Art development as:

'Islamic art developed from many sources: Roman, Early Christian art, and Byzantine styles were taken over in early Islamic art and architecture; the influence of the Sassanian art of pre-Islamic Persia was of paramount significance; Central Asian styles were brought in with various nomadic incursions; and Chinese influences had a formative effect on Islamic painting, pottery, and textiles.' (Grabar, 1987) P. 102

Marcelo Guimaraes Lima in his PhD dissertation on: Islamic Art and architecture: An introduction to the architecture and the art of the civilizations of Islam stating:

'The shift of location of the central power from Damascus to the Mesopotamian areas resulted in a corresponding displacement of 
the influence of classical and Byzantine art and cultural standards in favour to Persian and local Mesopotamian models.' (Lima, 2011)

Houghton Mifflin described The Influence of Roman Arch in the field of Architecture stating:

'The Roman arch caused further architectural developments. Romans had combined arches to form ceilings or roofs called vaults. The Romans also used the principles of the arch to form a hemispherical ceiling or roof called a dome. An early example of a dome is the Roman Pantheon.'

Ignacio Arce who had carried out several extensive studies in Umayyad Arches, Vaults and Domes described in his paper: Merging and Re-creation. Contributions to Early Islamic Construction History stating:

'Ctesiphon in the Sassanid era, was adopted by Umayyads in the vault of Qasr Al Hayr Al Sharqi and for those at the unfinished palaces of Mushatta and Qasr Tuba.

And added:

'Qasr Al Hayr, hybridisation with Byzantine techniques however is evident as for the combination with stone springing voussoirs, or the setting of secondary rows of "standard-laid" brick vaults over the pitched ones'.

And Described:

'Usually is reinforced with vertical protruding 'ribs'. Its use seems to be restricted to this geographic area.'

He also described the Brick Masonry Methods by stating:

'Brick masonry and its most relevant structural achievement, the barrel-vaults built without centering are the most significant Mesopotamian contributions to the ancient building technology. And introduced the early vaults history describing the Pitchedbrick cloister vaults or quadripartite lanceolate vaults. This characteristic vault founded in Khorasan area, especially around 
Merv and is the result of the intersection of two pitched-brick barrel vaults to form a cloister vault.'

Saeid Ali Buhlfaia described the Islamic Philosophy in architecture in his book: In Architecture

'Sophistications sincerity and perfection are important in Islamic thought, in the relationship of man with God, with the community and with the environment. Perfection is a strong demand in the teachings of Islam and a stage through which the noble mission should be accomplished perfectly. (Buhlfaia, 2006)

Silqini had describe an Islamic religious philosophy said by the prophet of Islam Mohammad:

'The Prophet embodied this idea in saying 'Allah loves, for anyone of you doing something that makes it perfect.' (Silqini, 2004)

P. 69-117.

Stefania Petralla on her paper: Arches and Ribbed Vaults of the Iranian Tradition described:

'Mosques, palaces, houses and even bazaars were all based upon bricks, the basic materials of every man-made construction; excavations made across the Iran have clearly shown that bricks form the skeleton of all ancient buildings. This material has significantly contributed to the development of building techniques, also influencing architecture and attracting the attention of architects to its artistic potentialities.' (Petrallain, 2012)

And added in her paper: Historical vaulted constructions of the Iranian heritage mentioning:

'In Islamic world, just as in ancient Iran, brick art continued to evolve. Islamic architecture almost exclusively used bricks, masterfully taking advantage of its qualities as an essential building element. With changing architectural styles over the course of successive periods, many innovations were introduced.' (Petralla, 2013) 
Robert Hillenbrand proposed on his book the Islamic Architecture: form, function and meaning explaining the ethnic categories of mosque types. Dividing them into three main styles:

'There are three 'ethnic' architectural traditions: Arab, Turkish and Persian'. (Hillenbrand, 1994) P. 64

Kuroh an Iranian Historian wrote:

'Religious beliefs, particularly during the Islamic period, played a decisive role in giving birth to the majority of Iranian architectural monuments.'

Earl Baldwin Smith in his book: The Dome, A Study in the History of Ideas defining domes as:

'Dome are rounded vaults made of either curved segments or shell of revolution, meaning an arch rotated around its central vertical axis. The terminology used has been a source of controversy, with inconsistency between scholars and even within individual texts.' (Smith, 1950)

While Coilum Hourihane had described domes in: The Grove Encyclopaedia of Medieval Art and Architecture defining the wooden domes as False Domes. (Hourihane, 2012) P. 302.

Ramin in Historical Iranian sites and people described:

'Originally the rubble walls were covered with stucco, which is still preserved in some places in the domed halls and in the court of the Palace.' (Ramin, 2009)

Michał Marciak has explained:

'The official religion of Sasanian Empire was Zoroaster and remained the official religion until the end of Sassanid Empire. Establishing altars was a necessity for Sasanian Empire and the 
architectural structure was a dome on four pillars surrounded by praying halls, rooms and other various halls.' (Marciak)

Encyclopaedia Iranica had defined:

'Sasanian building techniques did not change fundamentally in Iran with the Arab conquest, dating such buildings to one period or the other is often problematic.' (Iranica, 2015)

According to the classification suggested by Zaki Mohammad Hossain in Iranian Architecture in Isfahan:

'The archaeological excavations have provided sufficient documents in support of the impacts of Sasanian architecture on the architecture of Islamic period. In the Old Iranian architecture, semi-circular and oval-shaped vaults appeared and Iranians showed their extraordinary skill in making massive domes. Domes can be seen mainly in the structure of bazaars and mosques, and particularly in the historic buildings of Isfahan.' (Hossain, 2015)

Maryam Ashkan and Yahaya Ahmad mentioned in their paper: Persian Domes: History, Morphology and Typologies:

'Pre-Islamic domes in Persia are commonly semi-elliptical, with pointed domes and those with conical outer shells being the majority of the domes in the Islamic periods.' (Ashkan and Ahmad, 2009)

Oleg Grabar in his book The Earliest Islamic Commemorative Structures, Notes and Documents: Although the Sasanians did not create monumental tombs, the domed chahar-taqi may have served as memorials. (Grabar, 1966)

Lecture by Dr. Rafael Manzano Martos on November 17, 2010 at the School of Architecture at the University of Notre Dame described:

'Qubba stone domes are generally used in mosques and also in Mudejar and Christian shrines. In contrast, wooden domes usually appears in Caliphate palaces, like Medina Azahara; this type continued in all Taifa 
period palaces, Mohad and Nasrid. But they are also usual in Mudejar architecture of Christian Middle Ages palaces.' (Martos, 2010 )

\section{Paula Fuentes and Santiago Huerta stated:}

'A crossed-arch dome is a ribbed vault. The question arises as to the actual function of the ribs in supporting the dome. This question has been debated for more than two centuries in relation to The Gothic rib, but it has been rarely posed in relation to crossed-arch domes (Frankl, 1960). One reason may be the emphasis on decoration of the studies on Muslim architecture.' (Paula Fuentes and S. Huerta , 2010)

And added:

'Ribs are considered mostly as decorative. However the size of the arches in the vaults of the Maqsura of Córdoba, in the Armenian domes and in the Spanish ciboria does not fit with this hypothesis.'

Paula Fuentes in her PhD dissertation mentioned:

'Cross ribbed vaults first appeared in Cordoba in the second half of the tenth Century. Afterwards, this type diffused through Spain and North Africa in the eleventh until the thirteenth Centuries. These vaults reappear in Armenia in the thirteenth Century. In the fourteenth and fifteenth Century a few examples founded in both England and Central Europe. Islamic Iberia left rich heritage of exotic and beautiful palaces, mosques, minarets and fortresses in Andalusia. These buildings make Andalusia visually unique in Europe and have to be classed as its greatest architectural glory.'

Luis Ferre de Merlo in his paper: Bóvedas nervadas en el Castillo de Villena or Castillo de la Atalaya explained the Quadrilateral plan famed in Islamic Iberia as: 'A construction system brought to the Iberian Peninsula by Muslim invaders and had already tested in the early Islamic buildings and Persian construction.' 
And added:

'The constructions of ribbed domes used in Spain started in the tenth century by explaining Al Mohad period vaults and clarified the two types of vaults. The adobe walls covered by ribbed vaults and the difference of the Christians vaults built by ashlar walls and roof structure framework of wooden beams next level, while the latter is covered with barrel vaults.'

Antonio Almagro Gorbea and Alba Soler Estrela on: Survey of Vaults with Inter-crossed Arches mentioned:

'Al Mohad vaults with inter-crossed arches began in the tenth century in the mosque of Cordoba. The layout of their nerves materializes the decomposition into pieces of the vault using the geometry inherent to the architectural and artistic creations of Muslim culture. A rigorous survey, non-existent so far, has been done, through the use of different techniques, whose advantages and disadvantages are discussed. The geometric study of the vaults reveals its singularity, because they do not follow any of the models of other vaults using the same technique from al Andalus or North Africa, showing the enormous creative capacity of the architects based on geometry.'

Andrew Petersen mentioned in his book: Dictionary of Islamic Architecture describing: 'In Islamic buildings, vaulting follows two distinct architectural styles: Whilst Umayyad architecture continues Syrian traditions of the 6th and 7th century, Eastern Islamic architecture was mainly influenced by Sasanian styles and forms. 
P A R T I I I

3. TRACING HISTORY 


\section{TRACING HISTORY}

\subsection{History and the Birth of Islamic Domes}

Prior to the arrival of Islamic faith, the Arabian Peninsula was inhabited mostly by nomadic Bedouin tribes. They moved from place to place seasonally for the search of food and water. They were polytheistic people who worshipped nature. ${ }^{3}$ The first permanent architectural building in the Arabian Peninsula was The Ka'ba, ${ }^{4}$ which was built by Ibrahim and his son Ismail in the City of

[1] (Farooq, 1978) Mecca [1]. In the sixth century, the City became a great trading center profiting from the caravan trades between the Mediterranean and the Indian Ocean. These trades brought the cultures of China, Central Asia, Persia, East Roman, and India as well as building techniques from Ancient Civilizations [2].

Mohammed, the founder of Islamic religion, was born in Mecca in 570 AD. However, he was forced to leave for his religious teachings that annoyed the people of Mecca in 610. In Madinah, where he spent the rest of his life, he built a Mosque next to his house using the Egyptian mud brick building methods [Figure 33]. The original Mosque, which was built in $622 \mathrm{AD}$, was a rectangular enclosure,

[3] (James Stevens Curl, Susan Wilson, 1999) $30 \mathrm{~m} \times 35 \mathrm{~m}$, of palm trunks and mud walls with an open-air space [Figure 34] [3]. Mud brick and wood were the principal materials for construction traditional houses in the Arabian Peninsula [Figure 35]. The lower parts of the Arabian houses had thick walls strengthen

[2] (James Stevens Curl, Susan Wilson, 1999)
[4])H. H. Richardson, 1984) at the corners with wooden stakes laid horizontally, while the upper parts often had cantilevers [4]. However, the expansions of the Islamic faith from the Arabian Peninsula and Levant ${ }^{5}$ to

\footnotetext{
${ }^{3}$ Religion

${ }^{4}$ A cuboid building located in the City of Mecca.

${ }^{5}$ Palestine, Syria, Lebanon, Jordan
} 
Caucasus including North Africa, Egypt, Tunisia, Iran and Central Asia created a vast Islamic Empire. With this massive outgrowth the Islamic Architectural context developed creating historical Civilization. As no clear architectural identity had been established by the time Mohammed died and the fourth Caliphates came to an end ${ }^{6}[1]$. The Islamic Architecture initiated when Arab in the Arabian Desert adapted Islam and moved to Palestine, Jordan and Syria desserts where the birth of Dessert Castles developed for Nomads caravan and political negotiations. In spite of this, visiting Mecca had increased from diverse locations for Haj purposes. Several major routes led from Damascus, Baghdad and Cairo to Mecca. Each developed various facilities for travelers as wells, bridges, paved roads, khans and castles. Of all these routes Damascus route appeared to be the oldest. All of these routes contain remains of early Islamic buildings associated with Hajj and Craven travels.

'At the oasis town of Mecan there is also a huge Roman reservoir and there are signs that the nearby Roman fortress at Udruh was converted into an official Umayyad residence at this time.' (Petersen, 1996) [2].

A massive art of West and East were occupied by Muslims during their great expansions. Over the centuries, the Holy Mosques in Madinah and Mecca were embellished by different architectural elements from other empires. Several Islamic dynasties developed after the birth of Islam. Each empire had its own art, architecture and structural methods. These architectural differences were produced by climate conditions, construction materials and reginal culture. The buildings were reflection of the
[1] Dr. Farooq had mentioned in his Doctoral unpublished Thesis: Religion Impact on Islamic Architecture:

'There are certainly enough grounds for stating that Mohammed succeeded in his mission for the very reason that he was from Mecca City and not a Bedouin. But without the mobility and soldierly power of the Bedouins the religion he preached could never have spread with such overwhelming rapidly over the world.' (Konash, 1978).

[2] (Petersen, 1996) P. 105

\footnotetext{
${ }^{6}$ First four caliphs following the death of the Islamic prophet Mouhammad
} 
periods in which they were built and the dominant religion of the area [1]. The large expansion resulted into braking off the Great Islamic Empire into sub dependant and independent dynasties for people of [1] (K. A. C. Creswell and various Berbers, Arabs and Persians. In addition there are also Muslim braches Sunni, Shiite and Ibadi communities which developed and ruled local regions. These Independent dynasties such as: Rustamid, Fatimid, Zirids, Hammadids, Moravids and Mohads left mark to the Islamic Architecture context. The exposure of pre-Islamic ancient civilizations starting from late naturalistic tradition ${ }^{7}$ to the fine art developed by Byzantines and Sassanids were key marks to the birth of Islamic. These introduction to the previous civilizations created the birth of Islamic Architecture. Artists who adopted Islam as a religion and artisans of the region had developed new techniques and converted the Islamic philosophies into expressions emerged by previous civilizations to distinctly become Islamic in character [2]. James W. Allan, 1989)

[2] (Hillenbrand, 1994)

\footnotetext{
7 The actual art on the eastern shores of the Mediterranean
} 


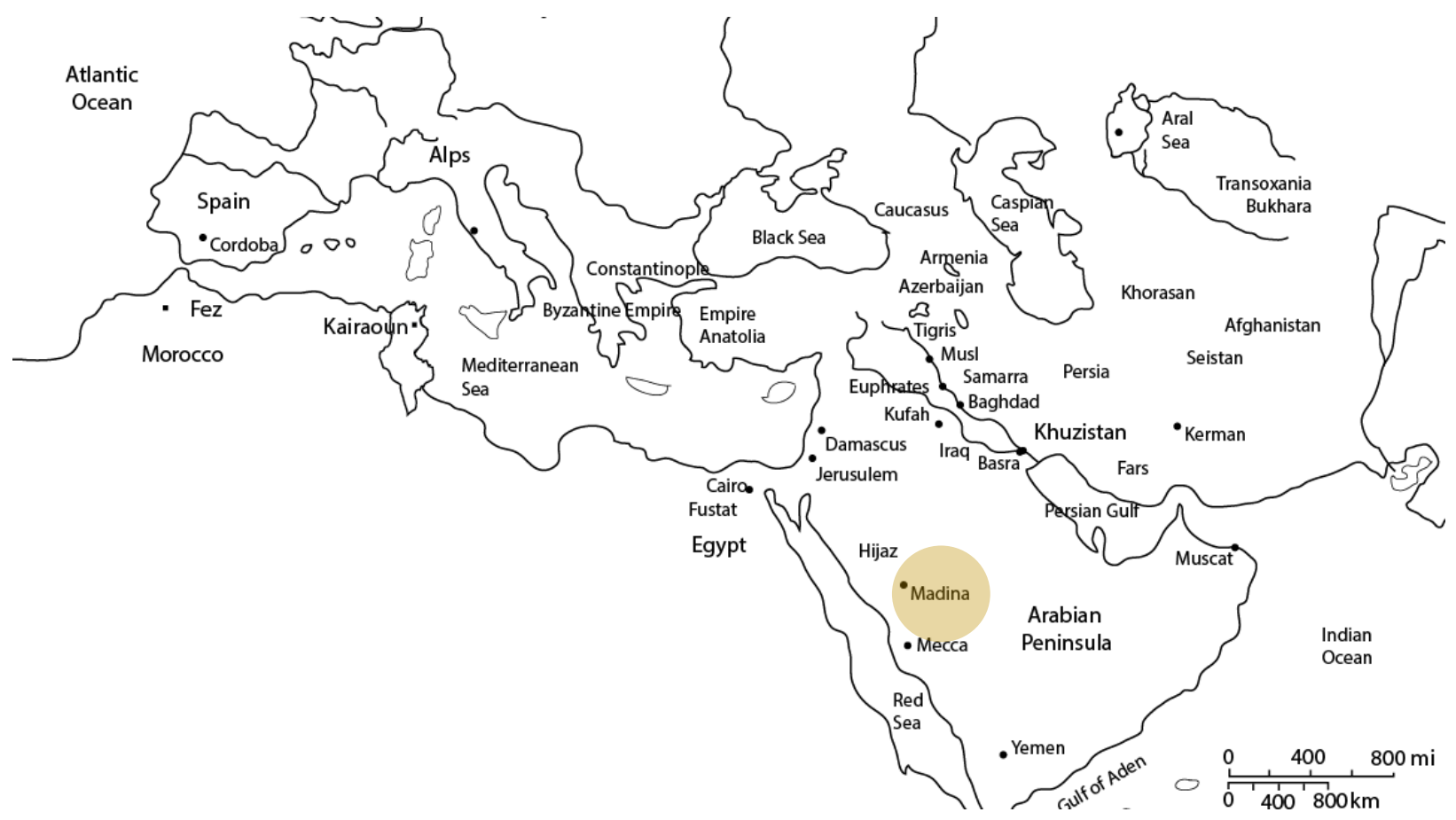

Figure 33: Prophet Mohammed's Mosque, Built in 622 AD

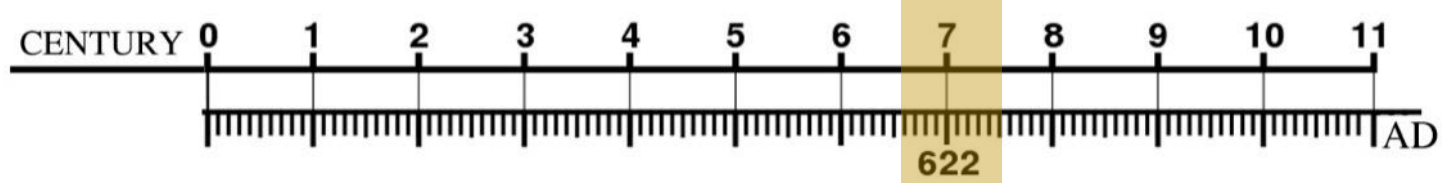

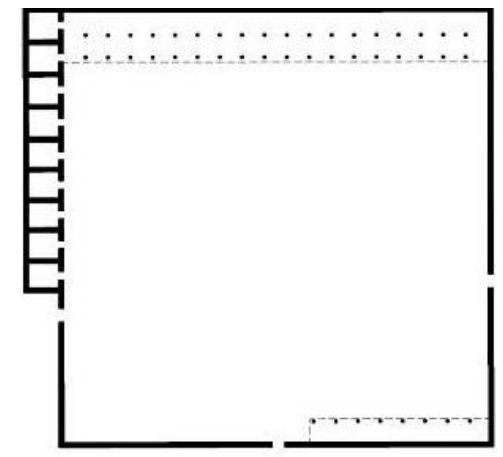

Figure 34: Prophet Mohammed's Mosque Plan

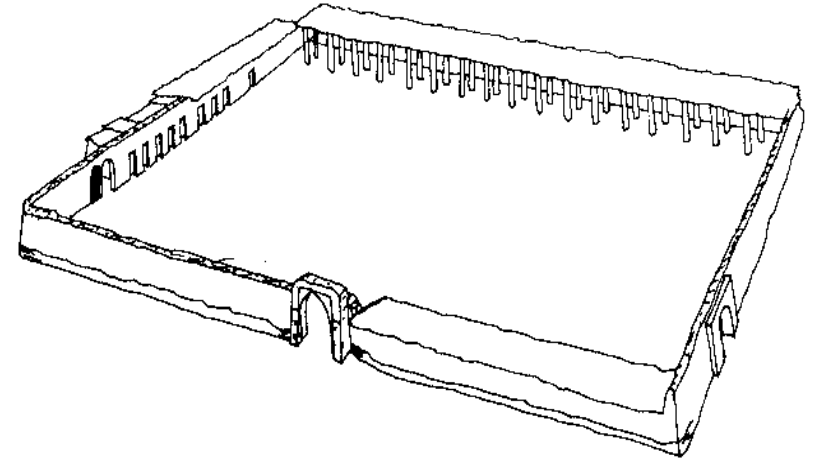

Figure 35: Prophet Mohammed's Mosque view.

Source: After Creswell 
Islamic Dynasties Periods in Islamic Iberia and North Africa

\begin{tabular}{|c|c|c|}
\hline ISLAMIC DYNASTY & YEAR AD & INFLUENCES \\
\hline Rashidun Caliphate & $632-661$ & No Architecture \\
\hline Umayyad Caliphate & $661-750$ & Roman, Byzantine, Sassanid \\
\hline Umayyad Emirs of Cordoba & $756-929$ & $\begin{array}{c}\text { Roman, Byzantine } \\
\text { Visogthic }\end{array}$ \\
\hline Umayyad Caliphs of Cordoba & 929-1031 & Emirs of Cordoba \\
\hline Abbasid Caliphate & $750-1258$ & Sassanid, Central Asia \\
\hline Idrisid & $788-791$ & Umayyad \\
\hline Aghlabid & $800-909$ & Khorasan \\
\hline Samanid & 819-999 & Khorasan \\
\hline Tahirids & $820-873$ & Sassanid, Khorasan \\
\hline Saffarid & 861-1003 & Afghanistan, Central Asia \\
\hline Tulunid & $868-906$ & Abbasid \\
\hline Fatimid Caliphate & $910-1171$ & Khorasan \\
\hline Moravid & $929-1031$ & Andalusian \\
\hline Ikhshidid & $935-969$ & Abbasid \\
\hline Sanhajah & $972-1148$ & Fatimid \\
\hline Zirids & $930-1090$ & Fatimids \\
\hline Moorish Taifa & 1031- 1287 & Umayyad \\
\hline Seljuk & $1037-1043$ & Persia \\
\hline Mouahid & 1149- 1269 & Moravids \\
\hline
\end{tabular}

Table 1: Islamic Dynasties Periods in Islamic Iberia and North Africa 


\subsection{Umayyad Era Introduction: 661- 699 AD}

The formative period of Islamic architecture begun in $661 \mathrm{AD}$ during the initiate of Umayyad Dynasty in Damascus. The shift of the Islamic capital controlled by Muawiya bin Abi Sufyan from Madinah to Damascus associated with the birth of the Islamic architecture as it introduced Muslims to Roman and Byzantine buildings [1]. The location of the capital was the main inventive influence to Umayyad Dynasty markable phase in Architecture. Later, Sassanid Architecture was introduced through the Tiger River road, which connects the two major cities Bagdad and Damascus [Figure 39] [2] [3]. Starting in 685 AD, there were notable changes in release of talent and creativity, which appeared during Caliph Abdul Al Malik bin Marwan period. Andrew Petersen extensively discussed in his book: 'Dictionary of Islamic Architecture' the history of Arab Architecture stating:

'As Arabs did not have an architectural tradition suited to the needs of a great empire, they adopted the building methods of the defeated Sassanian and Byzantine empires. Since they ruled from Syria, the Byzantine influence was stronger although the Sassanian elements became increasingly important. But in many cases Byzantine or even Roman buildings were simply taken over with little or no modification. However, the conquests did provide some innovation both in terms of building types and in the prominence given to decoration [4].' (Petersen, 1996)

Ignacio Arce in his research study: Umayyad Arches, Vaults \& Domes in numerous described the Umayyad Architecture:

'Umayyad architecture and construction techniques are, up to a point, the result of a successful eclectic merging of Late Roman traditions and Partho-Sassanian ones, due to
[1] In 661 Ali, the last Orthodox caliph was murdered and Mu'awiya, the governor of Syria, became the first Umayyad caliph. At its height Umayyad rule extended from the Atlantic coast of North Africa to India and from Central Asia to Yemen.' (Petersen, 1996)

[2] (K. A. C. Creswell and James W. Allan, 1989)

[3] (Rosenwein, 2004) p. 71

[4](Petersen, 1996) 
the need to establish new cities in the conquered territories.' (Arce, 2000s) [1].

[1] (Arce, 2000s)

\subsubsection{The Birth of Umayyads Domes: 685- 691AD}

The first and oldest Islamic Architectural invention was built during 685-691 AD to form the double wooden dome in Jerusalem, named as the Dome of the Rock [Figure 36]. The structure is consists of a domed octagonal shape set in the middle of a raised enclosure [Figure 37] [Figure 38]. There are also two other buildings of similar antiquity, a small structure called: The Dome of the Chain built in 691 AD famed as, Qubbat Al Silsila. This structure has the same basic plan of the Dome of the Rock, a free-standing octagonal structure covered with a dome. It is not a Mosque or Shrine, but used as a prayer house which later became a Christian Chapel under the Crusaders, then restored as an Islamic prayer house. In contrast, there was a third holiest site in Islam located in Jerusalem as well named as: Al Aqsa Mosque. The site on which the silver domed mosque located [2] [3]. [4].

The seizing of key areas of Byzantine Empire: Syria and Egypt. On the other hand, the whole area of Sassanids including: Mesopotamia, Persia and Central Asia had provided Islamic Architecture with two endless sources of construction traditions. Artisans and materials, that blended, and gave birth to new idiosyncratic Architecture [5].

[2] (Choisy, 1883 )

[3] (Creswell and Allan, 1989)

[4] (Hillenbrand , 1994)

[5] (Blair, 1991) 


\section{a. Dome of the Rock}

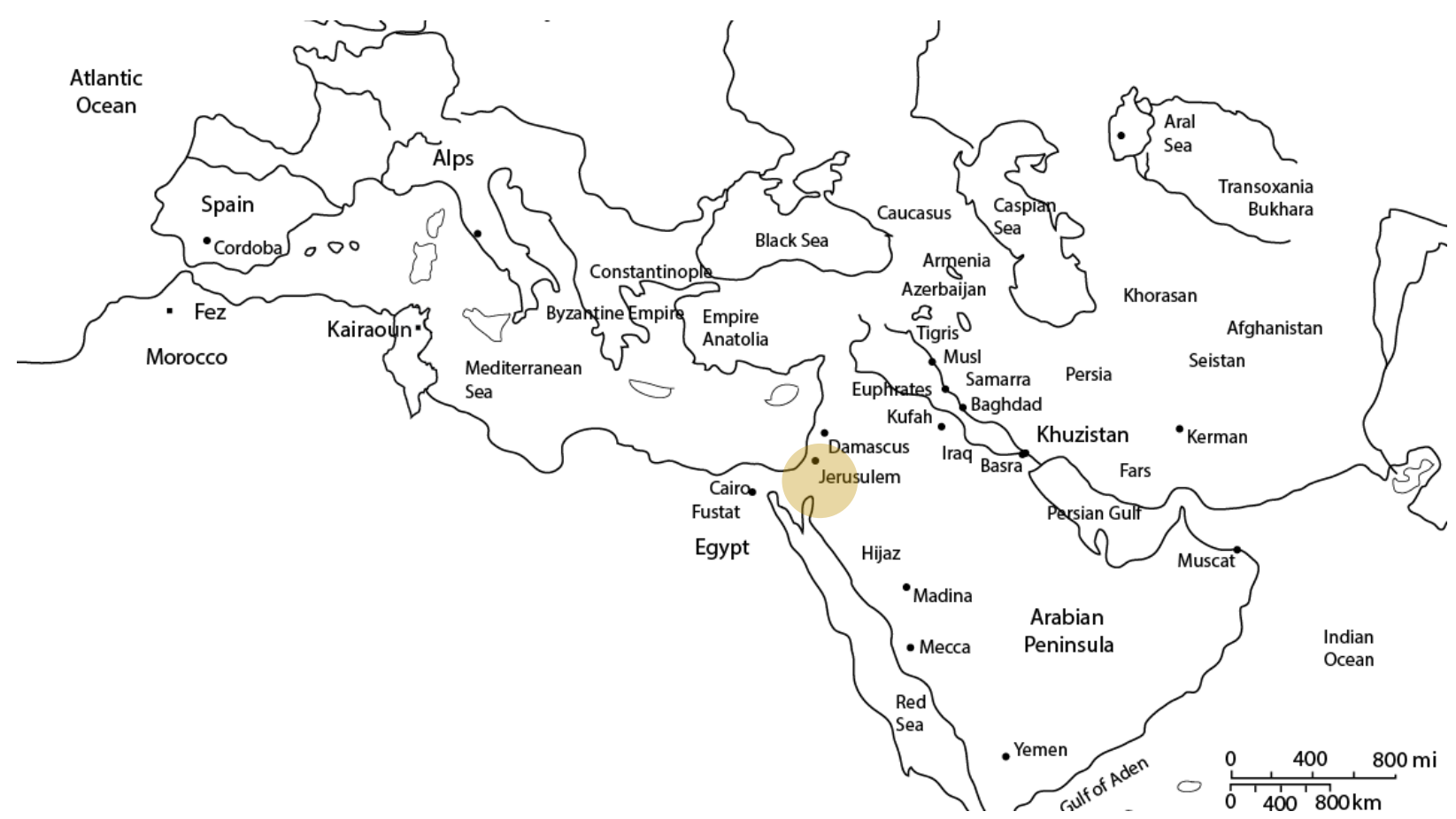

Figure 36: Dome of the Rock Location, Jerusalem

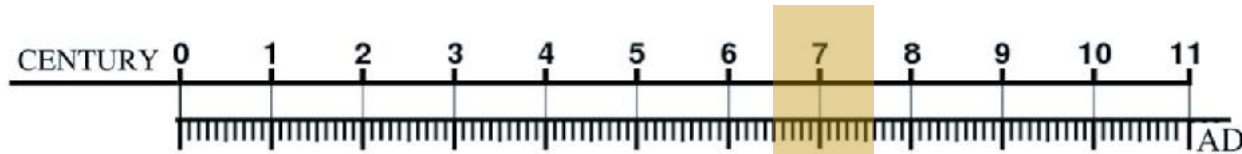

685

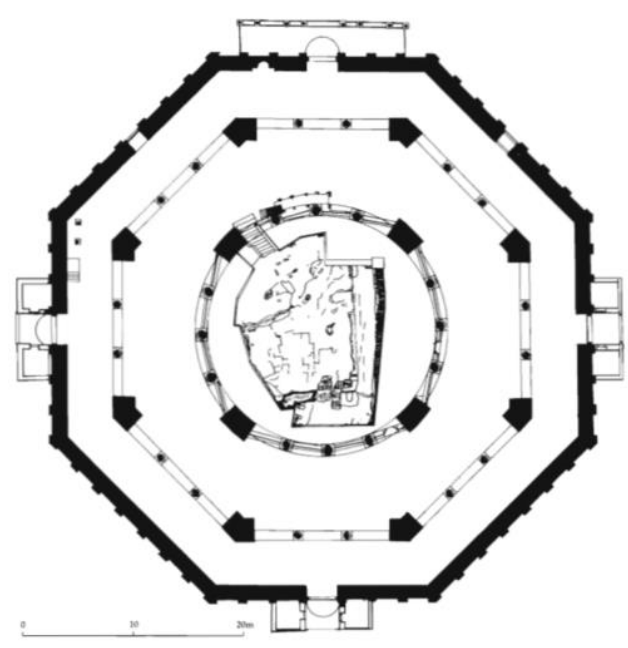

Figure 37: Dome of the Rock Plan, 692 AD

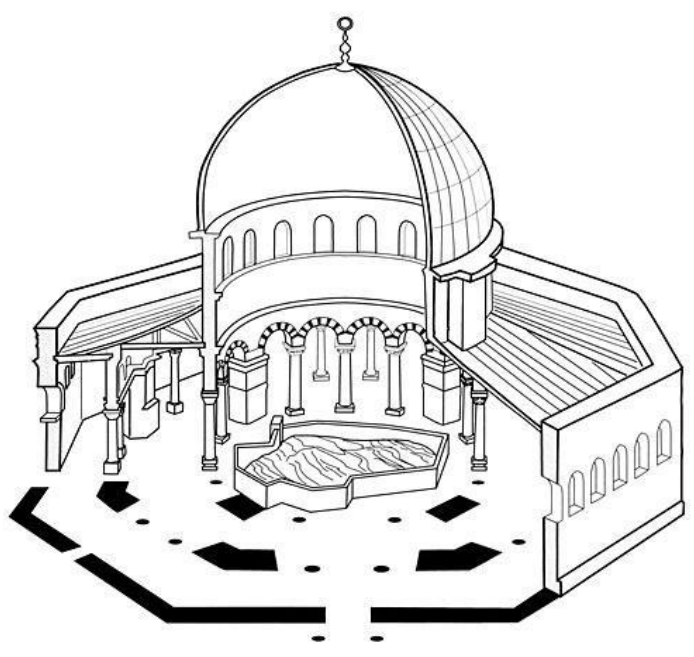

Figure 38: The Dome of the Rock, 692 AD

Source: After Creswell 
The settlement of Umayyads in Damascus resulted into the need for a Mosque to practice the Islamic religion and prayers. This necessity caused the conversion of the Byzantine Church to the Grand Mosque of Damascus. Initially, Muslim's conquest of Damascus did not affect the Church, as the building was shared by Muslim and Christian worshippers but a prayer room for Muslims had been constructed on the south-eastern part of the building made from mud bricks as it was the Basic Arab knowledge in building. It is vital to mention that the previous Byzantine Church or the current Mosque was an Aramean temple built in 1000 BC. Upon the foundations of these Armenian sanctuaries the Romans had built their temple then it was destroyed and a Church was built in its place by Byzantines. Under the Umayyad caliph, Al Walid, the Church was demolished and the present Mosque was built by the help of Coptic ${ }^{8}$, Persian, Indian and Greek craftsmen between 706 and 715 AD. The construction took ten years to complete and its columns were taken from the regional Roman historical temples. In 670AD, Umayyad had reached the ancient Roman province of Arica9 . The arrival of Uqba Ibn Nafa' resulted in founding the city of Kairouan and building the largest Mosque in the area during 670- 690 AD [1]. The Islamic religion customs and practices required needs for different usage of spaces. This was the initial phase to the birth of Islamic Architecture character. Mosques, Dessert castles and Hammams ${ }^{10}$ considered the initial Islamic buildings to the history of

[1] (Hillenbrand, Islamic Architecture, 1994) Islamic Architecture. Historians determined that the eight century of the Umayyad era is the initiate invention of Islamic Architecture [2]. In $707 \mathrm{AD}$, Caliphs Al Walid decided to enlarge the Holy Mosque of Al

\footnotetext{
${ }^{8}$ Ancient Egyptian

${ }^{9}$ Current Tunisia

${ }^{10}$ Bathrooms
} 
Medina and generated the construction materials from the Byzantine Empire complexes from Damascus to Medina. This approach called: Spolia which was defined by Philip Barker as:

'The repurposing of building stone for new construction, or the reuse of decorative sculpture on new monuments, is an ancient and widespread practice whereby stone that has been quarried cut and used in a built structure, is carried away to be used elsewhere.' (Barker, 2001) [1].

It was the start of Islamic Architectural rapid revolution. Soon after, several Dessert Castles and Mosques had been reconstructed in the desert routes linked to Mecca by Byzantine and Sassanid construction traditions for Haj and Caravan travels. Umayyad Desert Castles scattered in the desert of the Levant. Mushatta and Qusayr Amra Palaces in Jordan. Anjar in Lebanon, Khirbat Al Mafjar in Palestine, and Qasr Al Hayr East and West located in Syria all were built during the 700-750 AD [2] [Table 3]. Andrew explained in his book Islamic Architecture Dictionary relating to the Islamic buildings' locations by describing:

'Most cities and areas of settlement are either outside the area or located next to large rivers such as Nile, Tigris, Euphrates and Indus [3].' (Petersen, 1996) P. 65.

This theory, however, was challenged by the French scholar, Jean Sauvaget. He argued, the need for the Dessert Castles were for agricultural exploitations. This was produced by Umayyads to expand the agricultural zone into marginal areas. Yet another and more recent explanation for the raison of these buildings were for political agreements to maintain close contacts with the tribes of the region who were vehement supporters of the Umayyads [4] [5]. Further studies explained the need for these castles mainly for the annual caravan trips arriving to the Levant.
[1] (Baker, 2001)

[2] (Gazi, 2004)

[3] (Petersen, 1996) P. 65.

[4] (Sauvaget, 2010)

[5] In the Negev large numbers of early Islamic sites have been found, which indicate a growth in the settlement of the area. This parallels the increased building activity in the deserts of Jordan, Iraq and Saudi Arabia and may be linked to a shift in emphasis towards Arabia in the early Islamic period. (Petersen, 1996) P. 131 


\subsubsection{Umayyads Desert Castles Domes: 720- 750 AD}

Trading settlements and Hajj routes needed an independent complexes to tolerate their survivals [Figure 39] [1]. In early Islamic period, the architecture of the desert permanent palaces were built of pise, mud brick, baked brick, stone and more recent cement blocks and reinforced concrete [2]. Desert Castles are fortresses scattered over the Levant desert. These Castles were partly rebuilt from earlier Roman and Byzantine remains and partly since the Umayyads period in Damascus. Most of the Castles were built between the seventh century and eight century, roughly between 660 and 750 AD [Figure 40]. Only few were built since Roman times [3]. There are different theories concerning the use of the buildings. It is believed that some may have been built as caravan stations, some as resort pavilions for hunting, house traders or centers for agricultural purposes. The majority of these castles lie on the ancient trade routes towards the Arabia Peninsula from Great Syria and Iraq. These Dessert Castles represent the early Islamic Architecture. It is consist of wealthy decoration including frescoes, stone and stucco carving. Although the Illustrations demonstrate man, animals, some geometric patterns borrowed from Persian and Graeco of Roman traditions but they represent the most impressive examples of early Islamic art and Islamic architecture [4].

In reality, Desert Castles stand to the flourishing beginnings of Islamic Arab civilization. These seemingly isolated pavilions, caravan stations, secluded bathes, and hunting lodges when Muslim Arabs had succeeded in transforming the borders of the Levant deserts into well-watered agricultural settlements [5].
[1] Hajj, or pilgrimage, is one of the five pillars of Islam. Each Muslim is required to attempt at least once in a lifetime to visit the holy cities of Medina and Mecca. (Petersen, 1996) P. 104

[2] (Petersen, 1996) P. 65

[3] (Hoag, 1985)

Andrew Petersen in his Book Islamic Architecture Dictionary had described the categories of Umayyads' buildings into three categories.

Three categories: Roman Byzantine Architecture, heavily influenced by Sassanian architecturai concepts, and Buildings which combine both eastern and western traditions.

(Petersen, 1996) [3].

P. 140

[4] (Guides, 2016)

[5] (Petersen, 1996) P. 65 


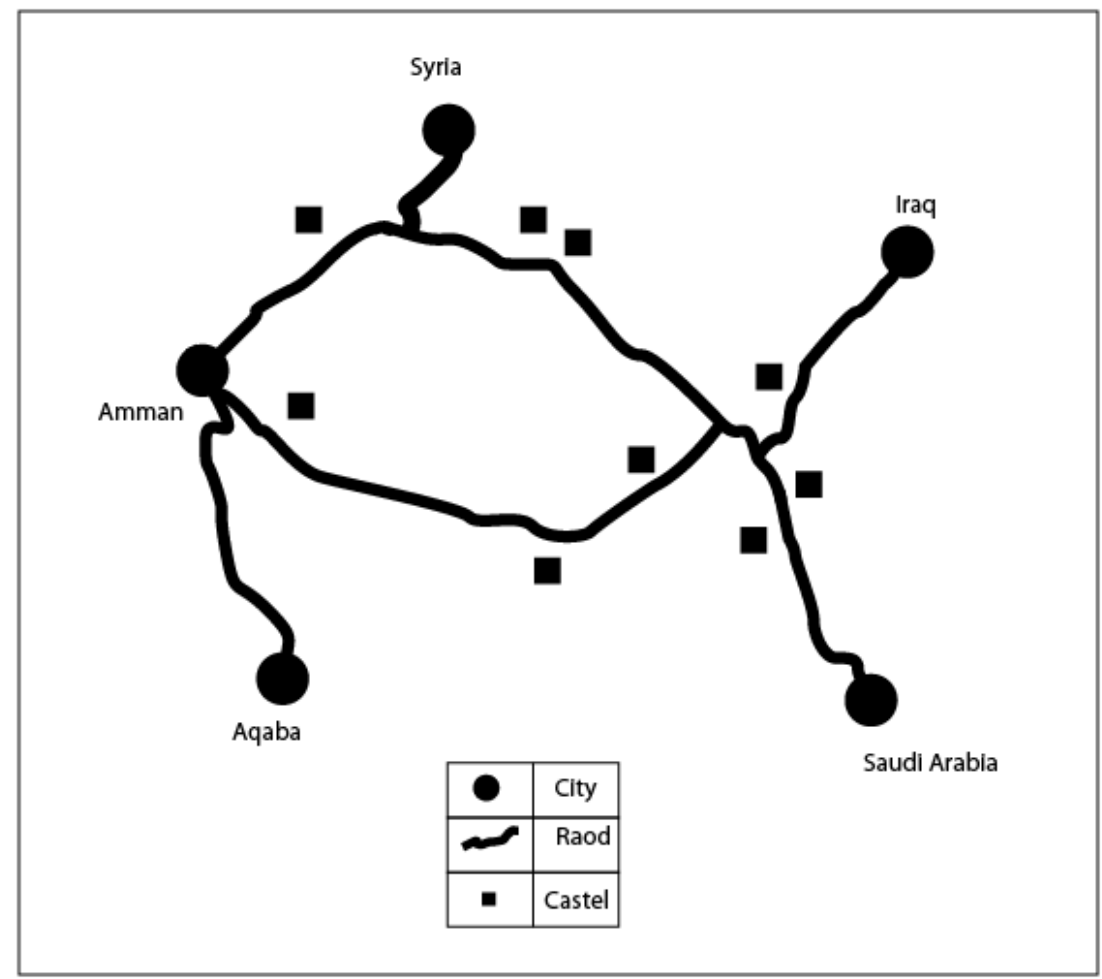

Figure 39: Nomads Road Trips

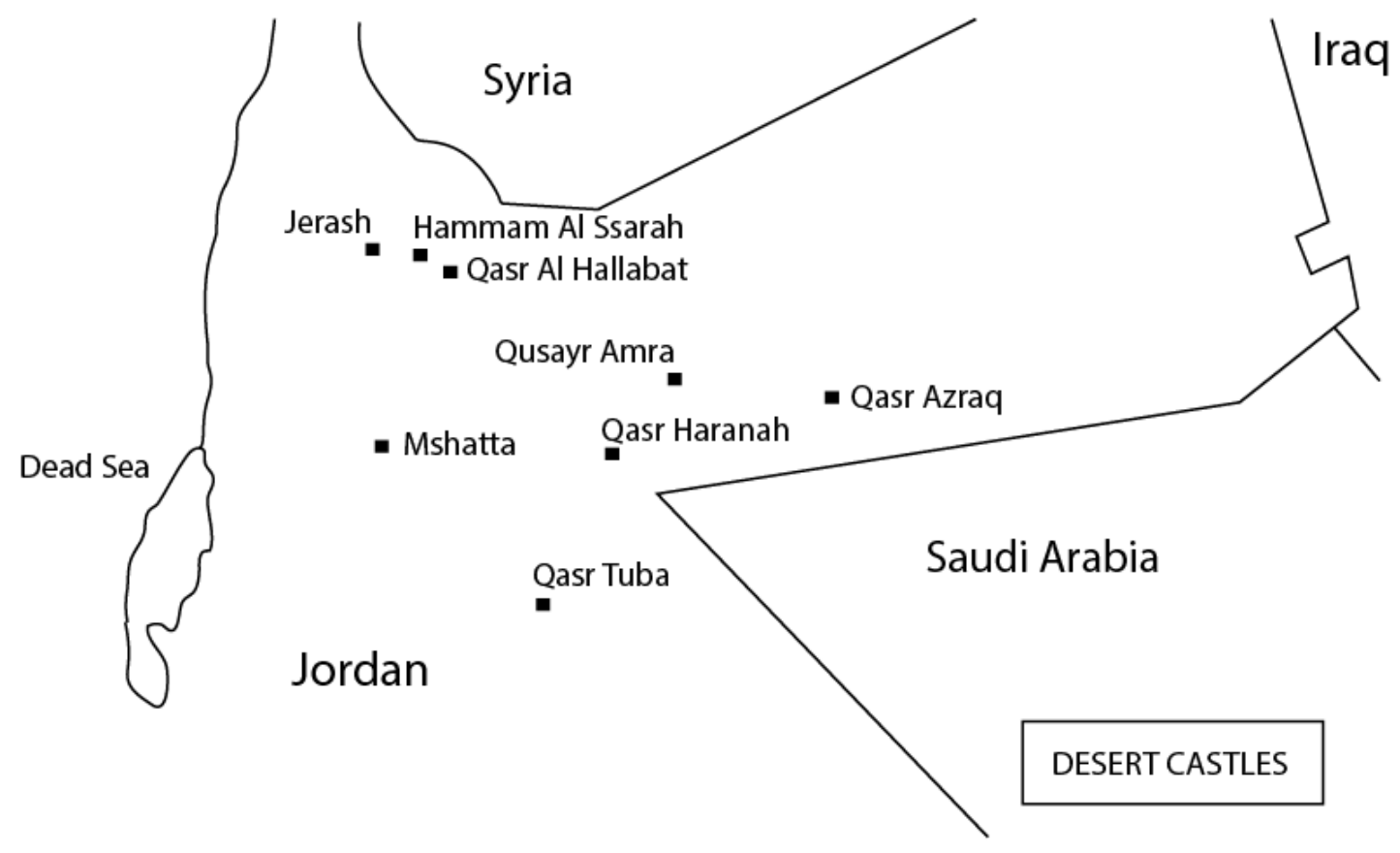

Figure 40: Umayyad Dessert Castles Locations 


\section{Qasr Ibn Wardan Vault, Hama in Syria: 527-564 AD}

Qasr Ibn Wardan is a previous Byzantine Church and Palace complex, Aleppo citadel, located at the edge of the desert to the northeast of Hama in Syria [Figure 41]. The complex was completed in 564 AD [Figure 42]. It was a defense complex of Persians in the East [Figure 43Figure 41]. Sofia in her Research paper explained:

'Using transversal arches to divide big areas into small sections is an improved version of the old Mesopotamian method. Samples of this can be seen in the Byzantine cistern at Aleppo citadel or at Qasr ibn Wardan which was erected in the mid VI century by the Byzantine Emperor Justinian I in 527-565AD as a part of a defensive line against the Sassanid Persians. Its unique style imported directly from Constantinople and not found anywhere else in present day Syria [1].'

[1] (Hoag, 1989)

Aguste Choisy in his book: The art of building among Byzantines stated:

Hybridisation of Roman and Persian techniques started much earlier with the adoption by the Byzantine masons of the pitched brick-vaults. (Choisy, 1883 ) [Figure 44] [2].

Ignacio added:

The main differences with the Persian vaults are the [2] (Choisy, 1883 ) great thickness of the mortar joints, and the not occurrence of totally vertical rows of brick arches in the pitched-brick vaults. Brick barrel vaults using the "Byzantine" technique are not found in Umayyad buildings, but mixed brick and stone masonry of Byzantine tradition occur in some Umayyad buildings. (Arce, , 2000s)

[3] (Arce,2000s)

The more important monuments are made of stone with baked brick or stone rubble used for domes and vaulting [Figure 45] [4]. A characteristic of the monumental masonry of Damascus is the use of

Ablaq, which is alternating courses of dark and light masonry made out of white limestone and black basalt. 


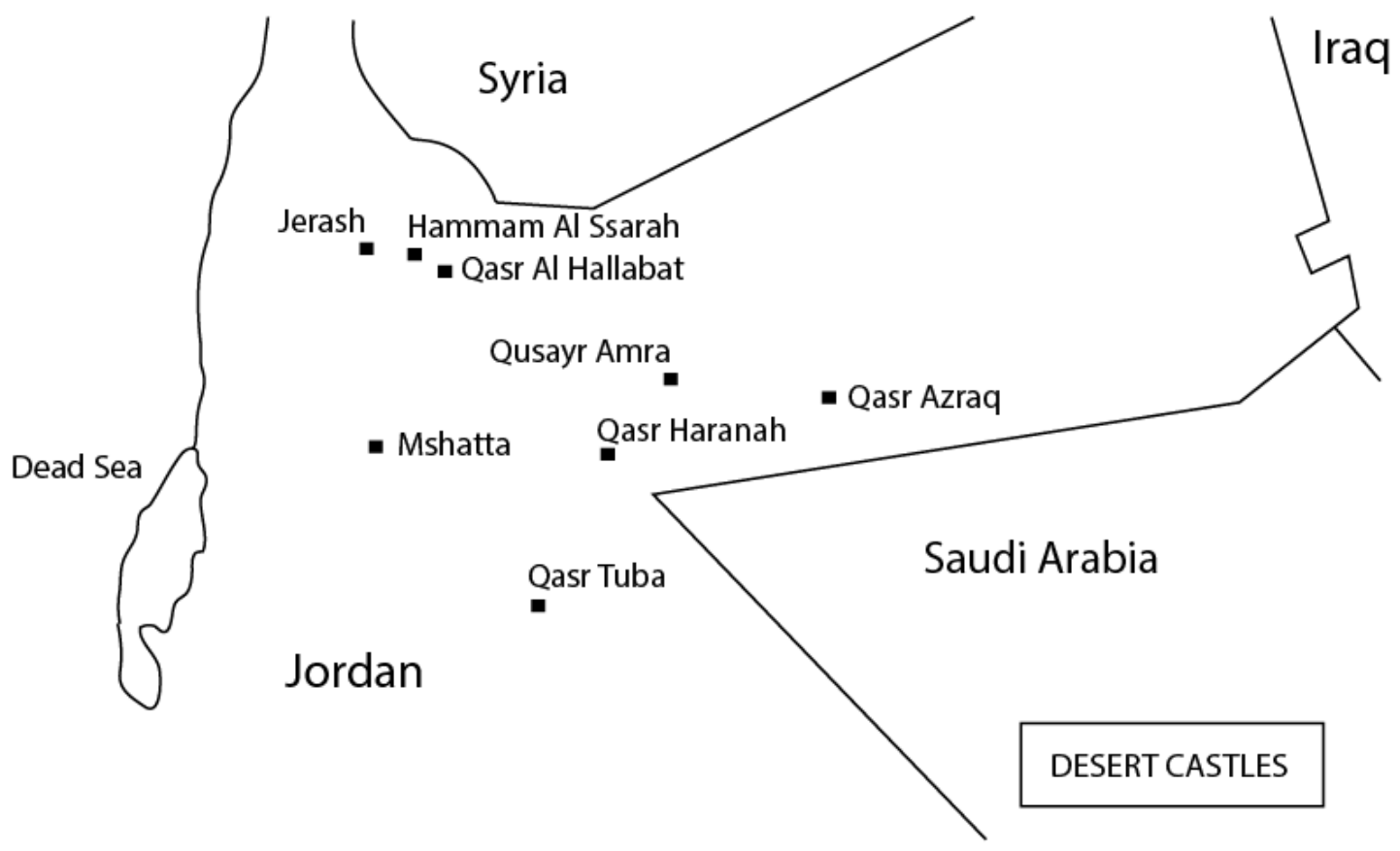

Figure 41: Qasr Ibn Wardan Location

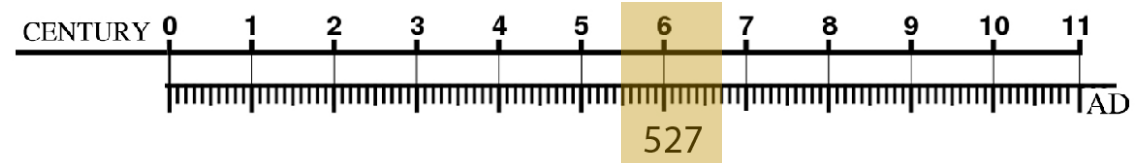

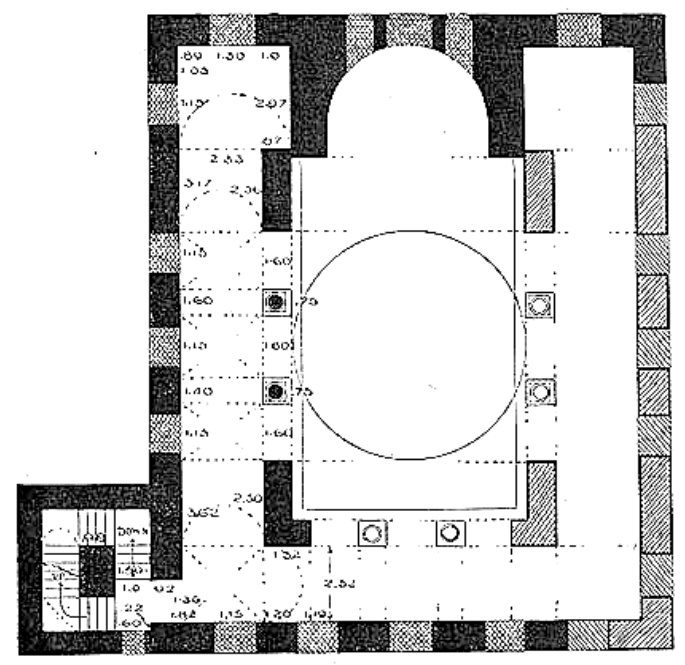

Figure 42: Qasr Ibn Wardan Plan Source: Archenet

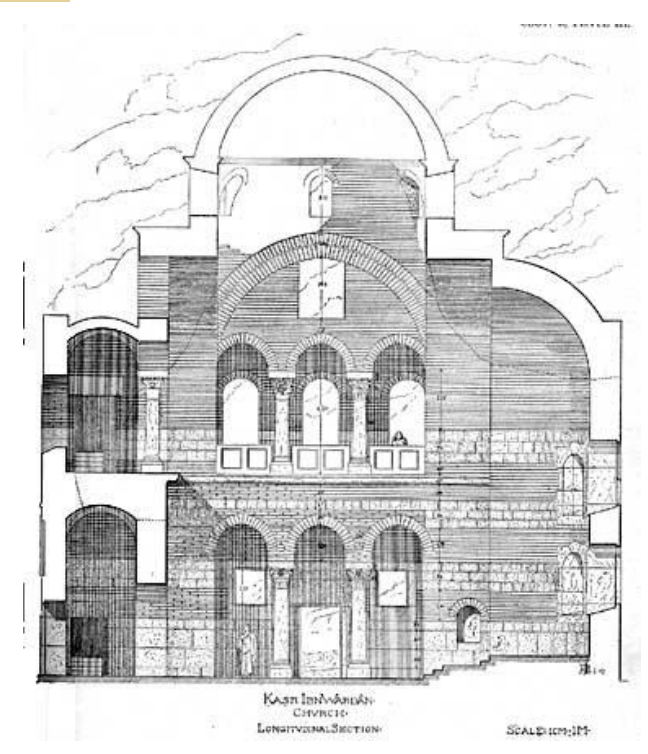

Figure 43: Qasr Ibn Wardan Section Source: Archenet 
Figure 44: Qasr Ibn Wardan Mixed Brick and Stone Masonry of Byzantine Tradition.
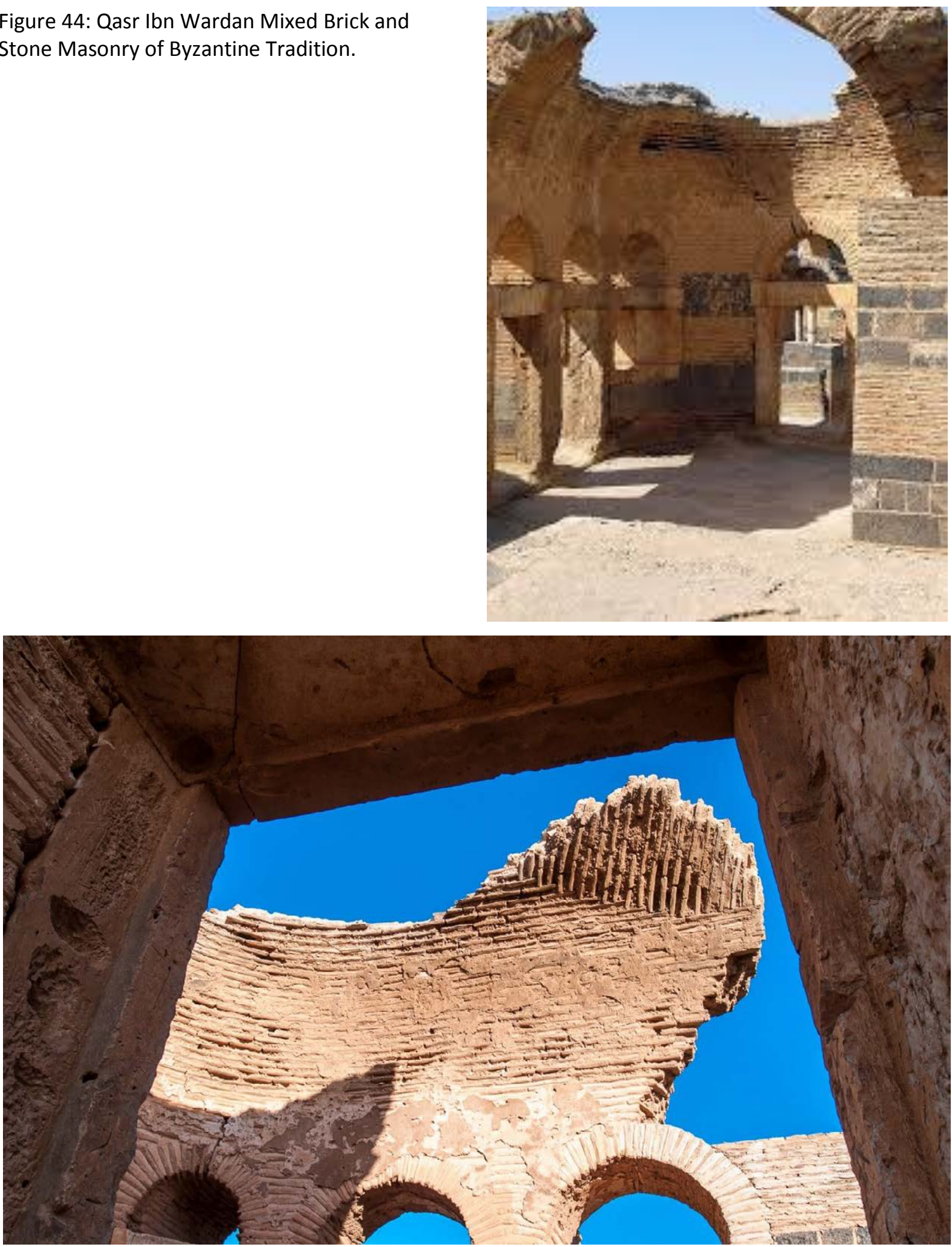

Figure 45: Qasr Ibn Wardan Mixed Brick and Stone Masonry of Byzantine Tradition 


\section{a. Azraq Castle Vaults: III century}

The Blue Fortress is a large Palace located in Eastern Jordan. The area was inhabited by the Nabataean then fell under the control of Romans. Romans had built structure using the local basalt stone that was reused later by Byzantine and Umayyad empires [Figure 49] [1]. Qasr Al-Azraq strategic value came from the nearby oasis, where the only water source in the vast desert region. The Romans were the first to make military use of the site, and later an early mosque was built in the middle during the Umayyad period. An extensive renovation and expansion done by Ayyubids in the thirteenth century, using locally basalt which makes the castle darker than most other buildings in the area. The castle in a square structure with 80 metre long walls with a large central courtyard. In the middle of the court, is a small mosque that dated from Umayyad times [2] [3]. At each corner of the outer wall, there is a tower. The main entrance is composed of a massive slab of granite, which leads to carved pavement of Roman drawings. Although each of the leaves of the main gate are very heavy but these stone doors can be easily moved. The Building contains unusual size of stones. The name of the Castle refers to the strategic significance of its location, which is in the middle of Al Azraq Oasis. Several civilizations are known to have occupied the site for its strategic value in this remote and arid desert area [4] [Figure 46].
[1] (Guides, 2016)

[2] (Cyril, 1964). P. 104

[3] (Archnet, 2016)

[4] (Sauvaget, 2010) 


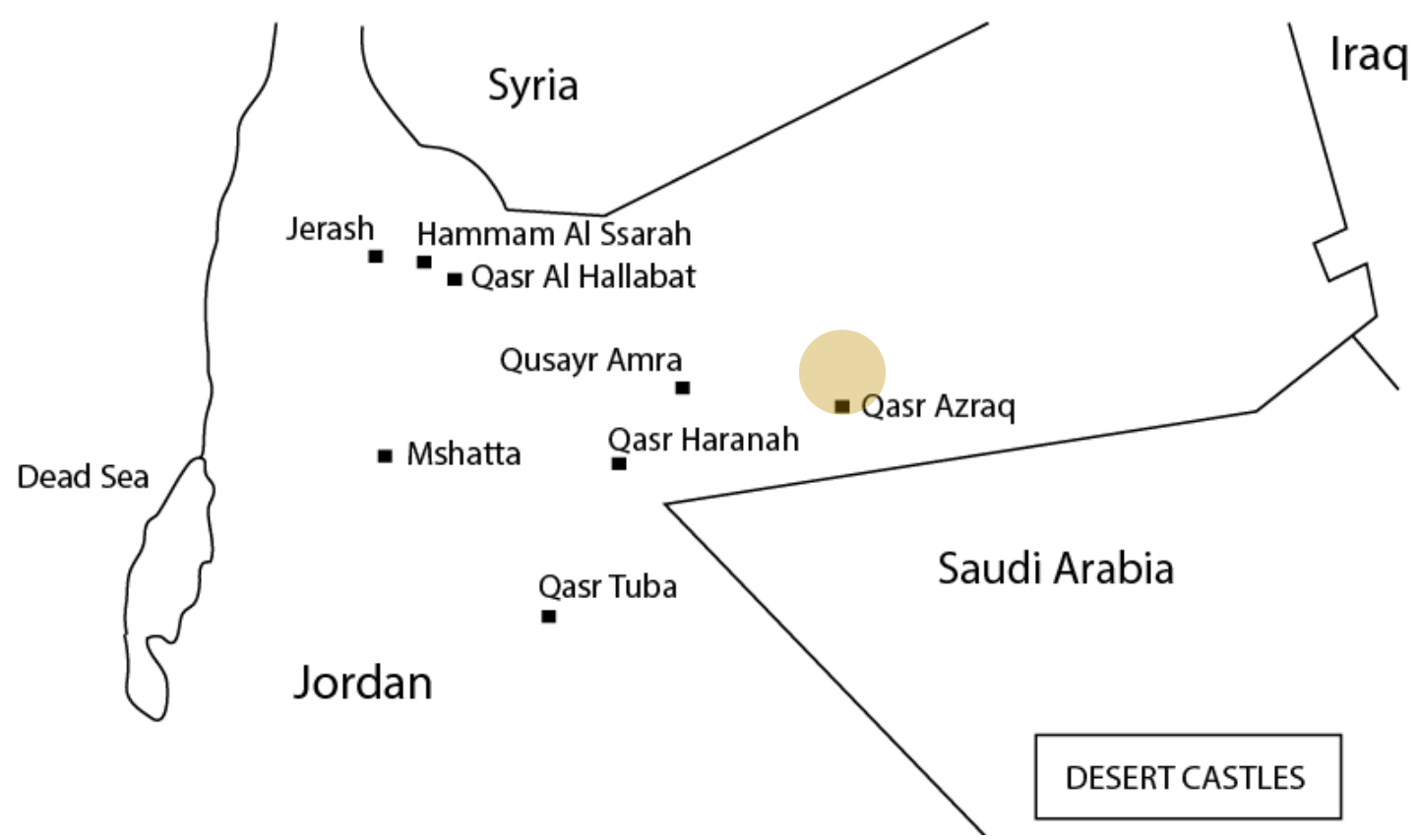

Figure 46: Qasr Al-Azraq Location

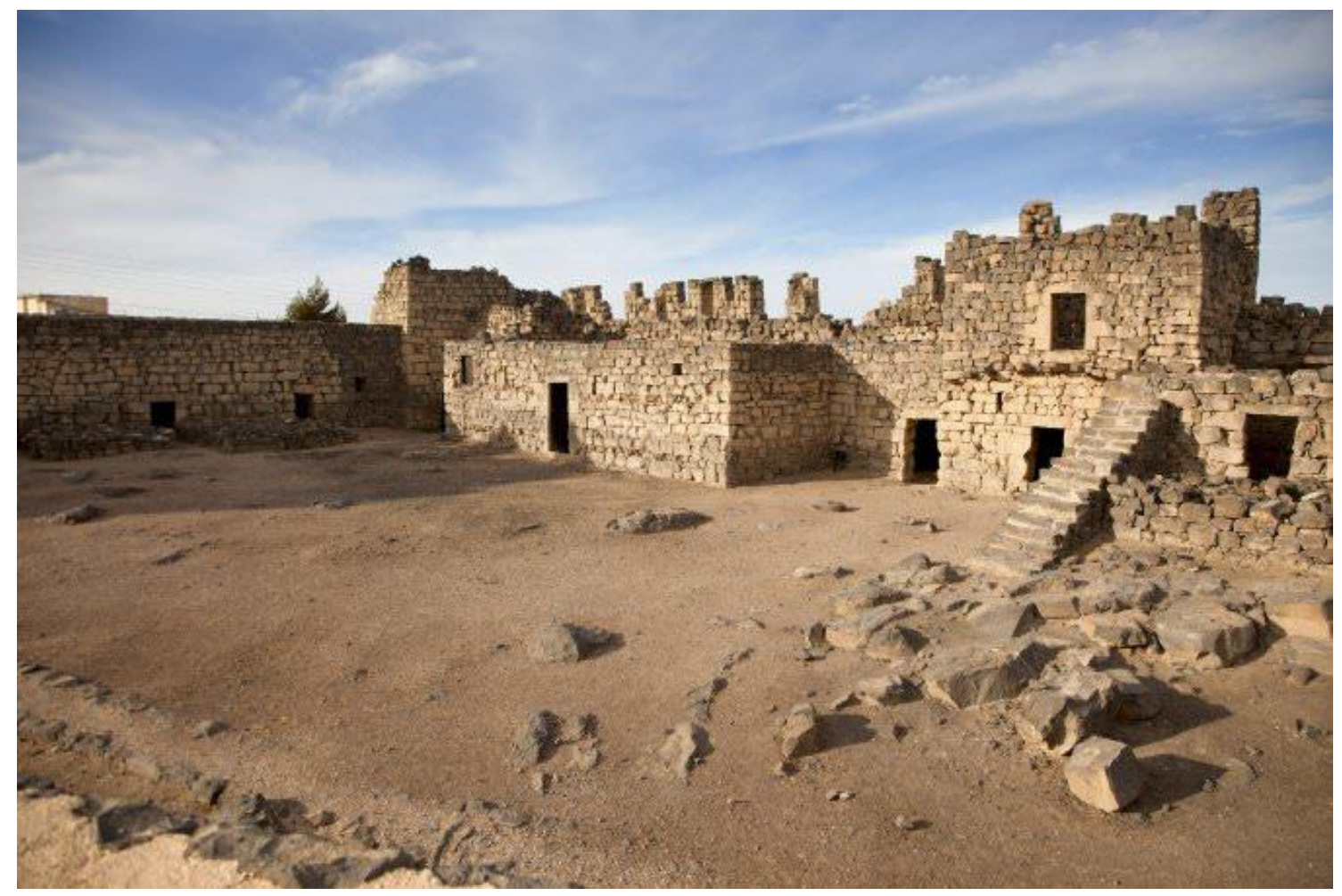

Figure 47: Qasr Al-Azraq Court

Source: Lonely Plant 


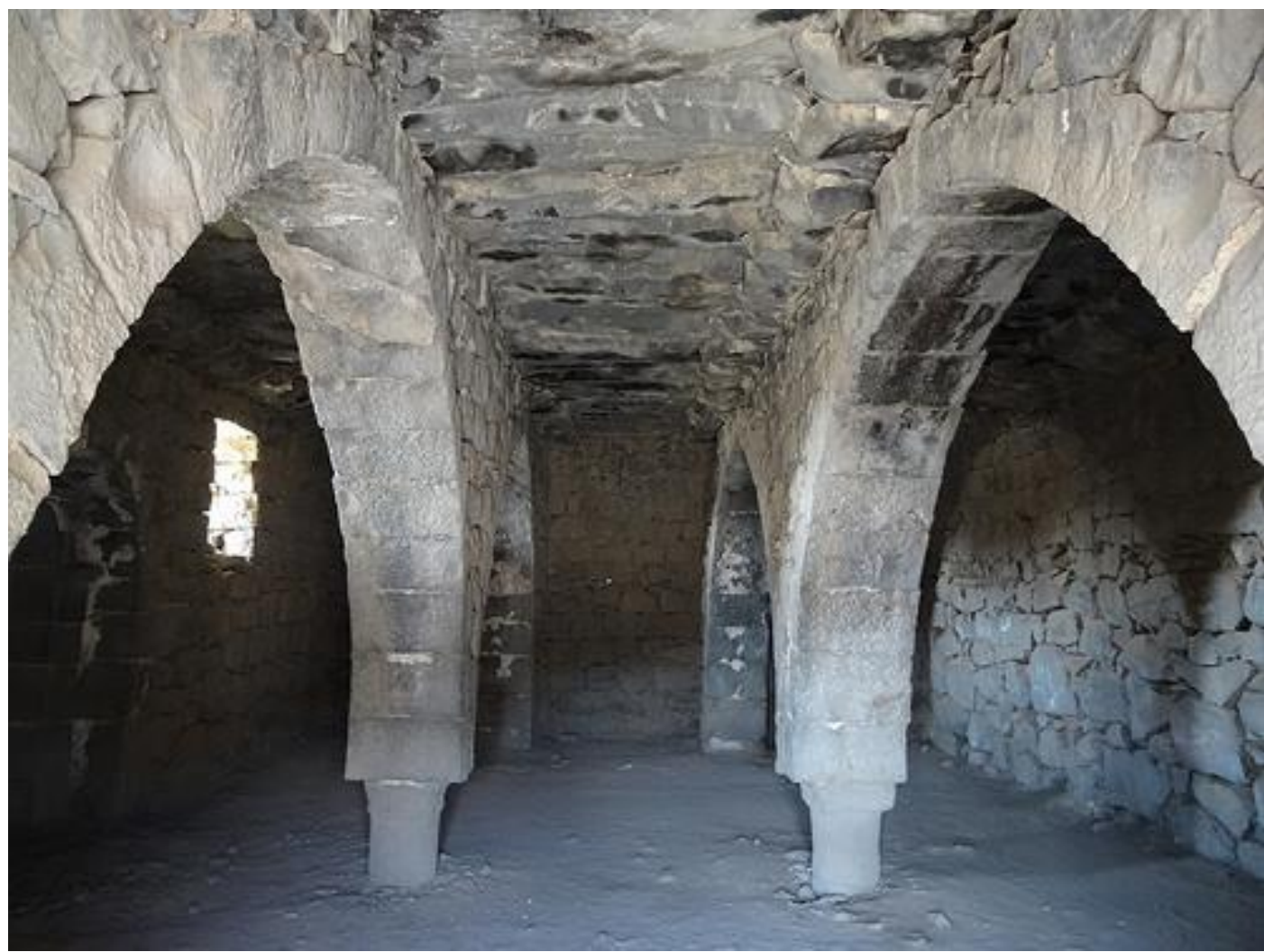

Figure 48: Qasr Al-Azraq, Interior of the mosque

Source: Daniel Demeter

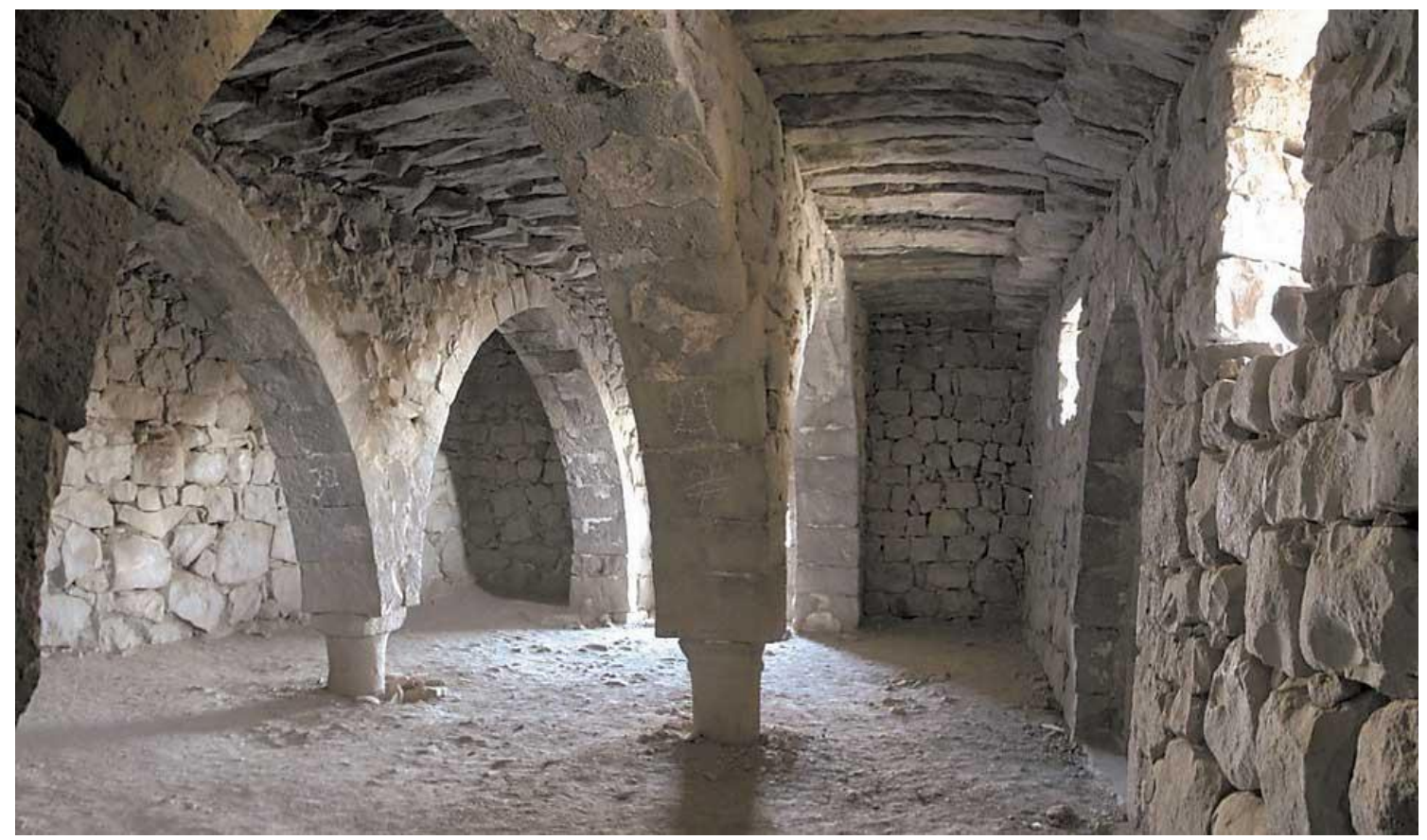

Figure 49: Qasr Al-Azraq, Interior

Photo by: Daniel Demeter 


\section{b. Qasr Harrana Vaults: 710 AD}

Harrana Castel was built in early Umayyad period by Caliph Al Walid I. The building is located $50 \mathrm{~km}$ East of Amman through Baghdad to Amman highway [Figure 50]. The Castle is two-storey square plan with small towers located in the corners and rounded entrance [Figure 54]. The Palace is made of rough limestone blocks set in mudbased mortar [Figure 53] [1].

Richard Ettinghausen, Oleg Grabarand Marilyn Jenkins mentioned in their book: Islamic Art and Architecture:

'Qasr Harrana combines different regional traditions with the influence of the new religion of Islam to create a new style. Syrian building traditions influenced the design of the castle, with the construction techniques applied in Sassanid.

The layout is influenced by Byzantine and Roman designs but the structural system of the castle is Sassanid Tradition, for the reason of the transverse arches supporting the barrel vaults. (Richard Ettinghausen, Oleg Grabar, Marilyn Jenkins-Madina, 2001) [2].

The discovery of various inscriptions in the construction shows two distinct phases of construction work: the first in the VIII Century and the second in the years 661 to $684 \mathrm{AD}$ [3]. According to scholar K.A.C Creswell the area was occupied by Persians for decades until the conflict with Byzantine Empire [4]. Qasr Harrana is an important example of early Islamic art and architecture. Two vaulted chambers that functioned as storage areas from the entrance hall of the Qasr at each side [5]. The corridor concludes to
[1] The best parallels for Kharana are to be found in early Islamic buildings in Iraq such as Khan' Atshan and Qasr Khubbaz which is built using the same materials (i.e. rough stone blocks set in mud mortar). (Petersen, 1996) p. 139

[2] Ettinghausen, Oleg Grabar, Marilyn Jenkins-Madina, 2001). P. 39

[3] (Michell, 1978)

[4] (K. A. C. Creswell, 1989)

[5] (Marciak, 2016 ) 
a central courtyard, which is bordered by three rooms on the ground level and five on the upper floor. Scholars had suggested that Qasr Harrana might have served a variety of defensive, agricultural and commercial agendas similar to other Umayyad palaces in greater Syria [1]. The main entrance facade covered with distinctive band of diagonal bricks up near the top of the walls. An arched portico originally ran round the courtyard, providing shade below. Virtually no direct sunlight could penetrate into the interior. All rooms surround the courtyard, including those upstairs, which typically Umayyad tradition, copied later on in Al Mushatta and Tuba Castles [2].

The upper floor had a semi-domed ceiling supported on squinches. One of the small, dark rooms on the south wall has a unique crossvaulted ceiling, restored later with decorated squares and diamonds not found elsewhere [Figure 59] [3]. Archnet scholars had suggested:

'New research posits that it could be a product of Saffarid rule where it's argued tribal political leadership prevailed. (Qasr al-Kharana, 2016)

Andrew Petersen had described the brick Method used at Qasr Harana in his book Islamic Architecture Dictionary by stating:

'The best-known Sassanid influenced building of the Eastern type is Qasr Kharana. The building includes in situ plasterwork on the upper floor which made out of roughly shaped blocks set in a mud-based mortar with decorative courses of flat stones placed in bands running around the outside of the building.' (Petersen, 1996) [1].

Internally the building is decorated with pilasters, blind niches and medallions finished in plaster. The whole appearance of the building is so different from other Umayyad structures in Jordan that scholars have tried to attribute it to the period of Sassanian
[1] (Marciak, 2016)

[2] (Ilayan, 2016)

[3] (Qasr al-Kharana, 2016)

[1] (Petersen, 1996)

P. 139 
occupation of the area despite an eighth-century inscription. (Petersen, 1996) [2].

Ignacio Arce described the Umayyad Architecture by stating:

[2] (Petersen, 1996)

'Umayyad architecture and construction techniques

P. 139 are, up to a point, the result of a successful eclectic merging of Late Roman traditions and ParthoSassanian ones, due to the need to establish new cities in the conquered territories and to create a new "aulic" imagery and an appropriate architectural framework for the new power. '

(Arce, 2000s) [3].

[3] (Arce, 2000s)

Such a hypothesis proposes that Qasr Harrana dates from the early Umayyad period. At its times, Qasr Harrana was considered one of the Umayyad potential palaces in the region as it is approximately one forth the size of many later examples. Scholars indicates that it could have represented a formal standard for new and developing Islamic typologies, as later Umayyad buildings had displayed alterative approach of architectural and decorative forms founded at Qasr Kharana [4].

[4] (Archnet, 2016)

'Harrana Castel was kind of rural conference center, used by the Umayyad caliphs as a comfortable and accessible place to meet with local Bedouin leaders, or even as a site where the Bedouin themselves could meet on neutral ground to iron out tribal differences. It was probably built in the late seventh century; a few lines of graffiti in an upper room were written on November 24, 710 $A D^{\prime}$. (Arce, 2000s) [5].

The central section of the cross arches built with rounded bricks of white limestone laid on a thick bed of mortar. Both mortar and stones are comprised by two lateral pre-cast gypsum ribs that work as a formwork and temporal centering that is left embedded in the arch afterwards. Pre-cast gypsum structural elements, such as [5] [6] (Arce, 2000s) these ribs, are purely Sassanian in origin [6]. 


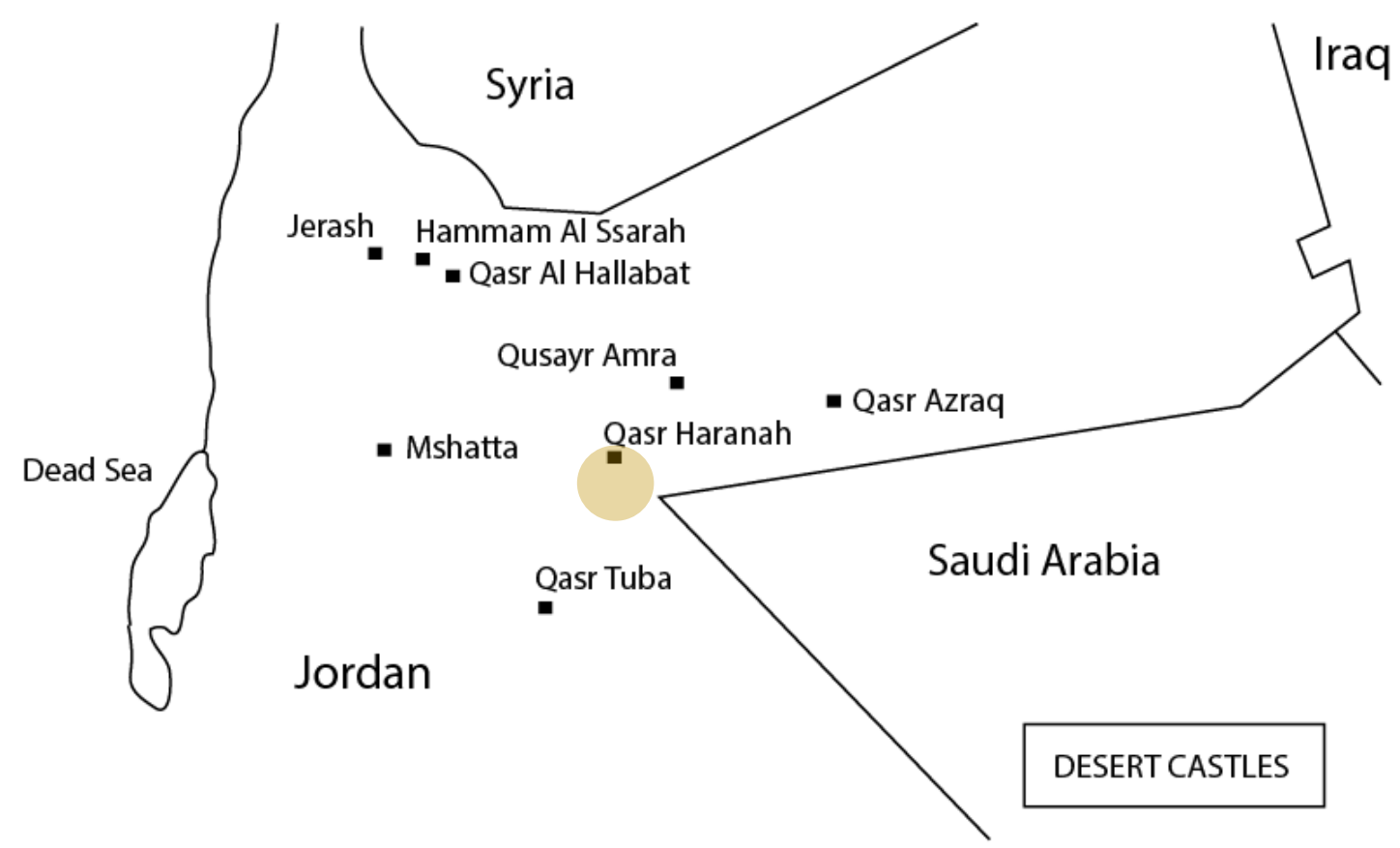

Figure 50: Qasr Haranah Location. 710 AD
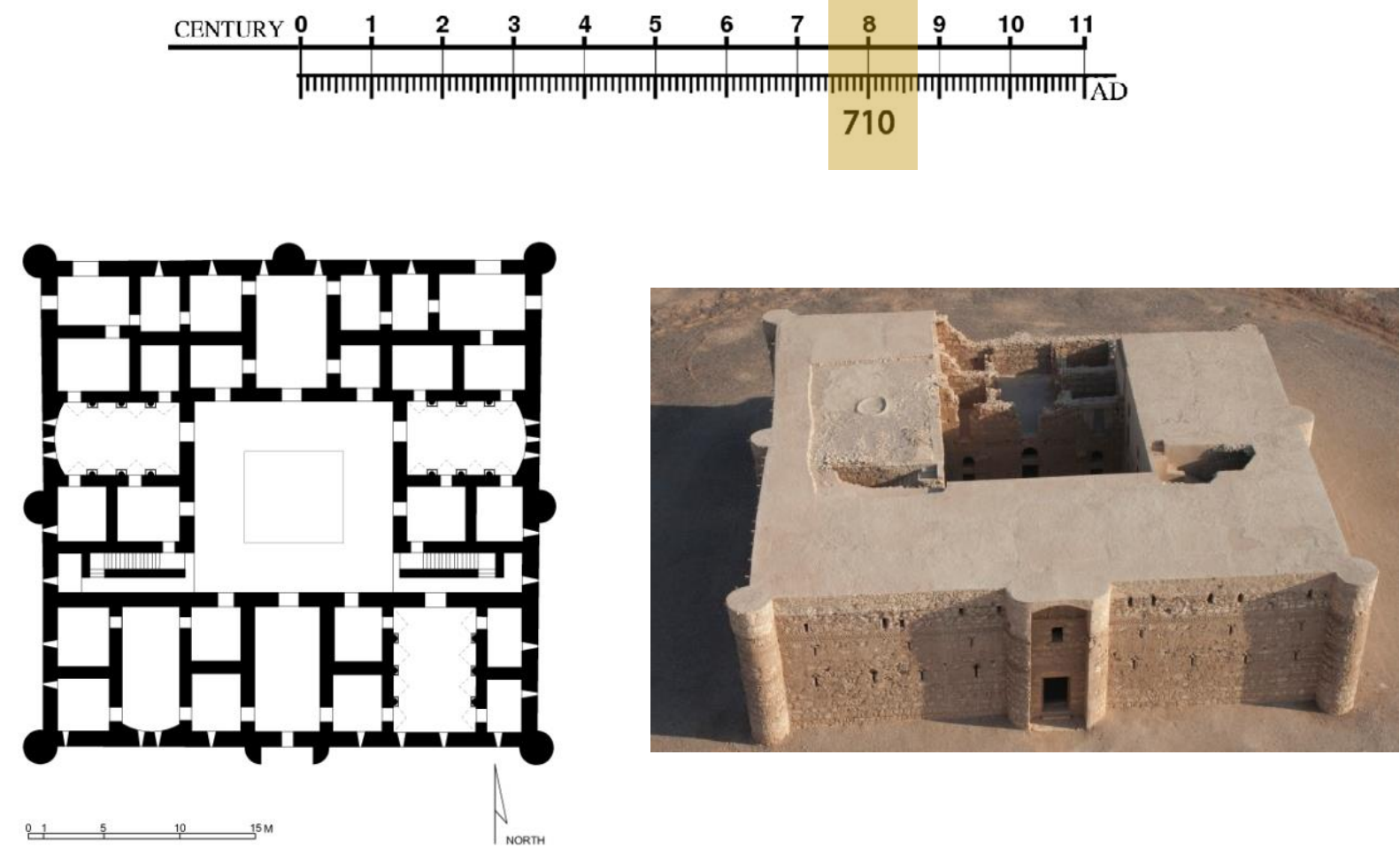

Figure 51: Qasr Haranah Plan,

Figure 52: Qasr Haranah Top View, 


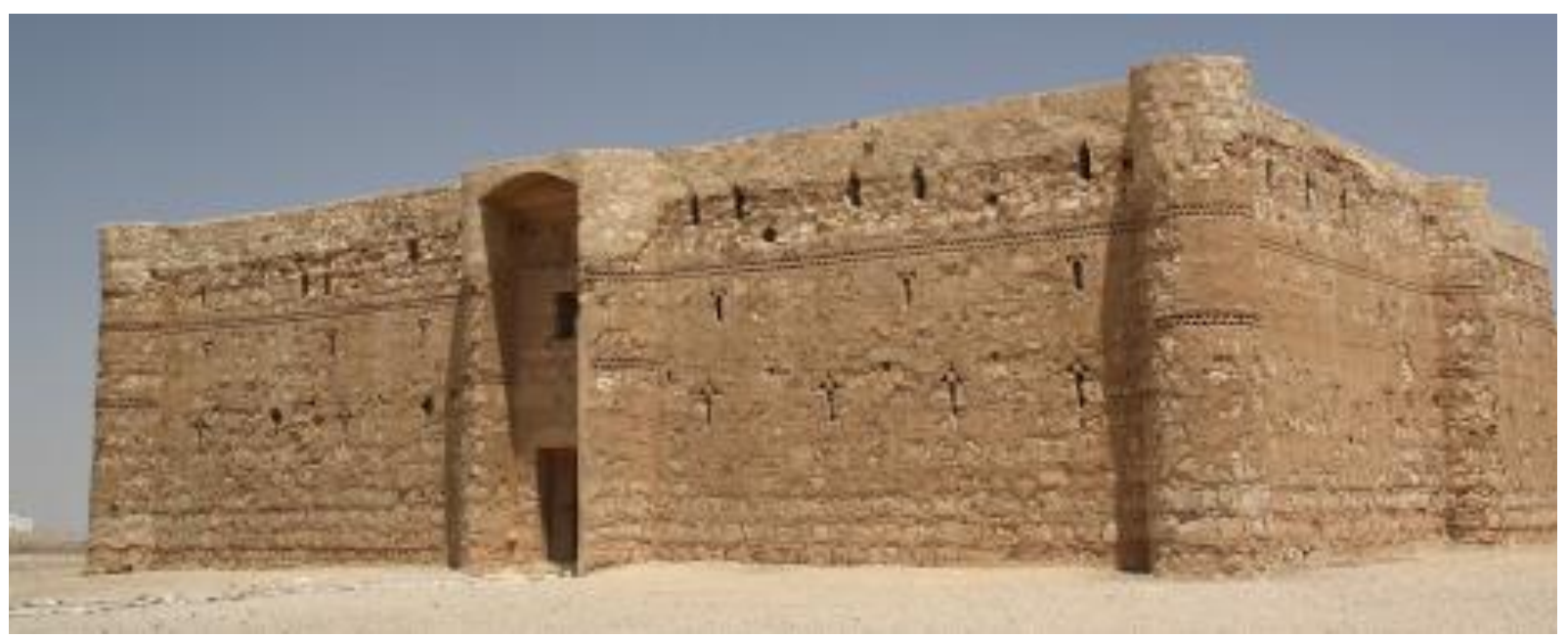

Figure 53: Qasr Harranah, Built 710 AD, Source: Army.arch

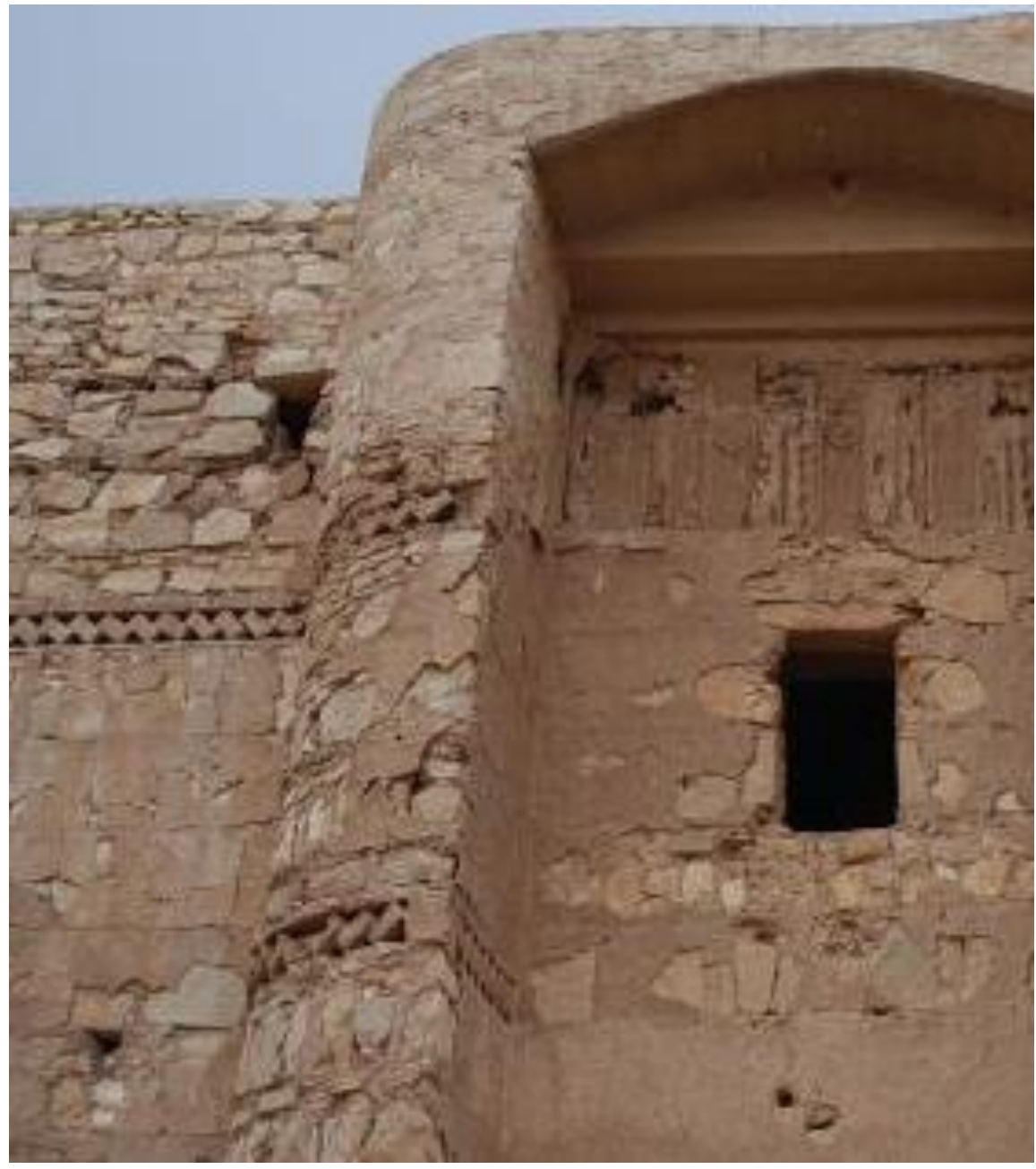

Figure 54: Qasr Harranah Entrance Brick Method, 710 AD

Source: Guide 


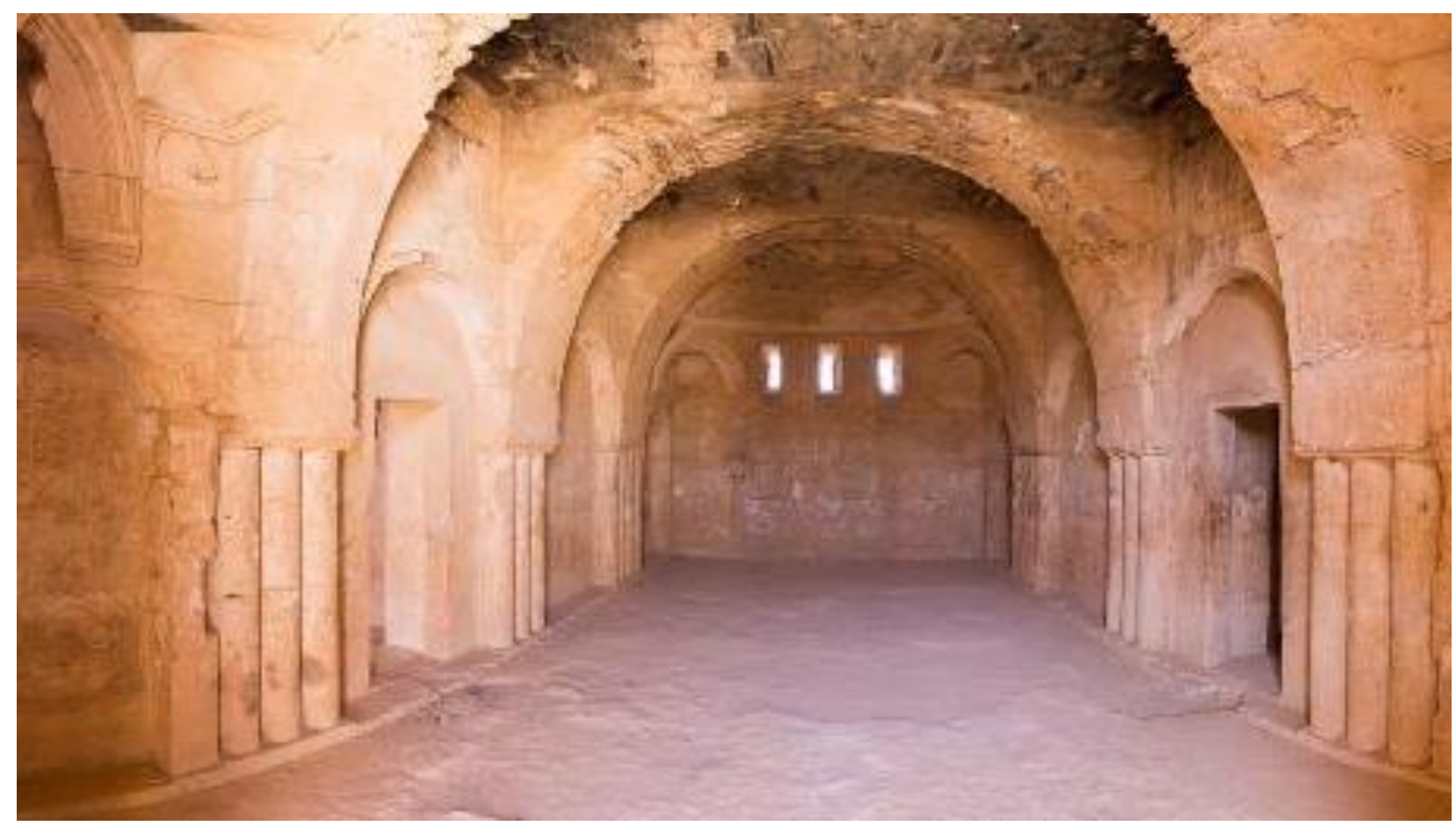

Figure 55: Barrel Vaults, Qasr Harranah Source: Trip Advisor

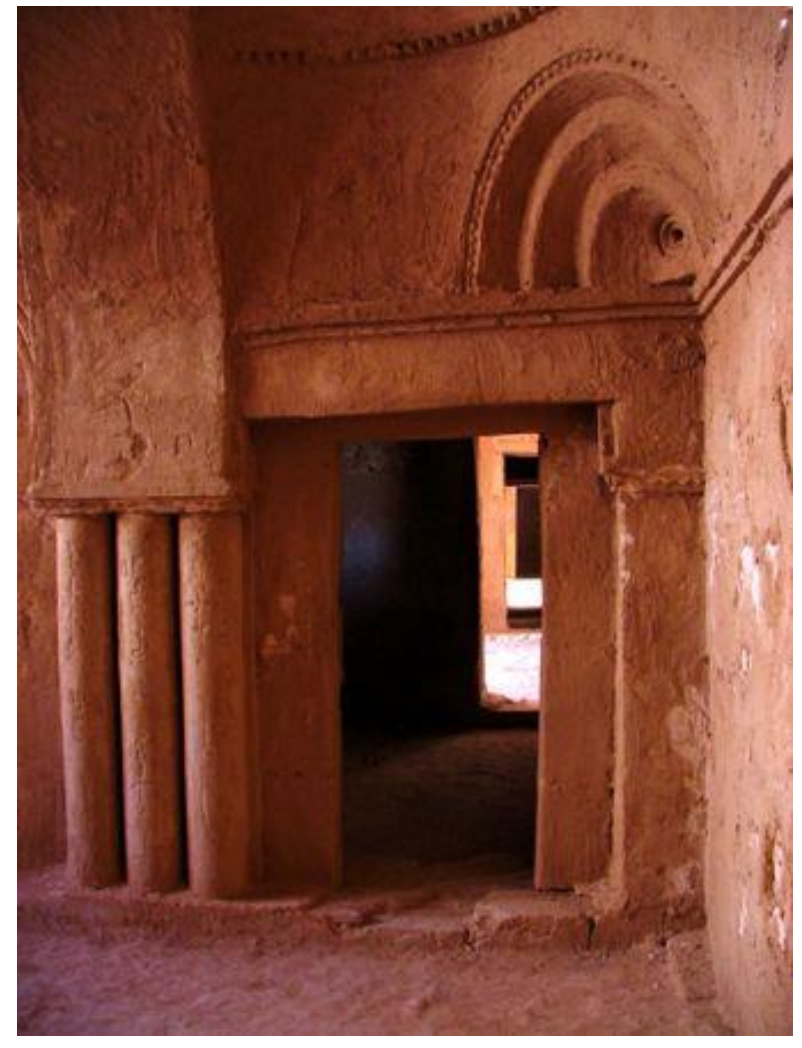

Figure 56: Barrel Vaults, Qasr Harranah Source: Army.arch

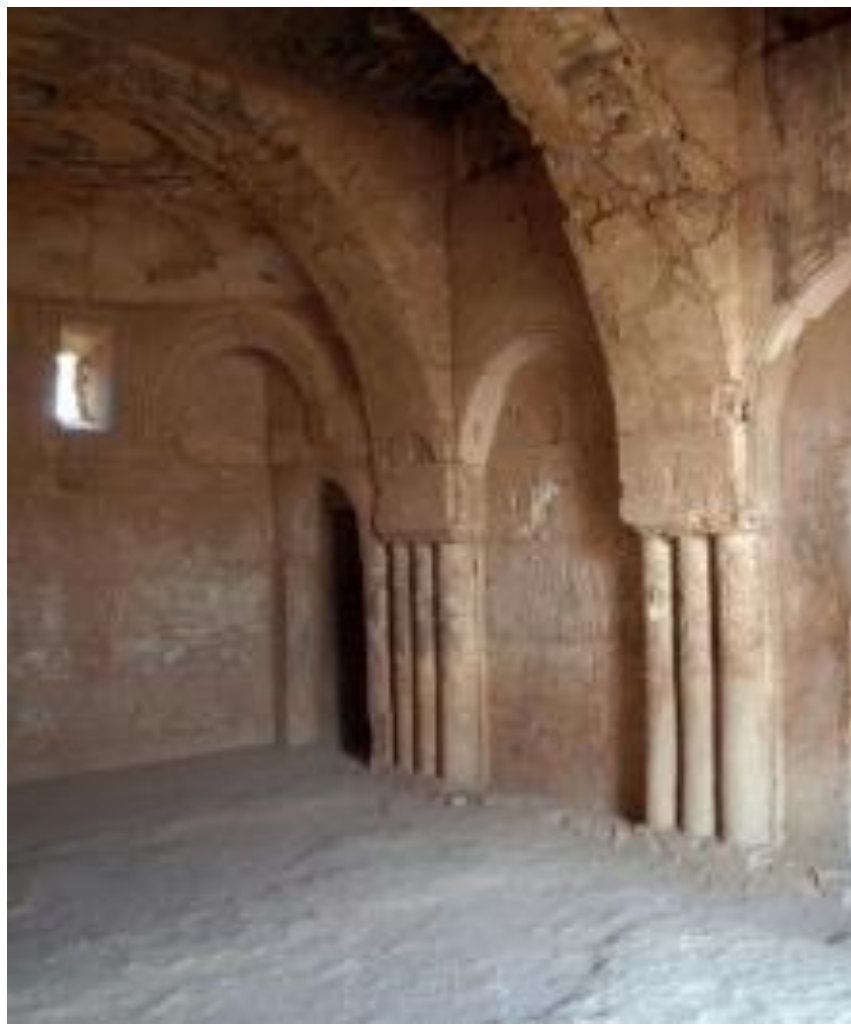

Figure 57: Barrel Vaults, Qasr Harranah Source: Army.arch 


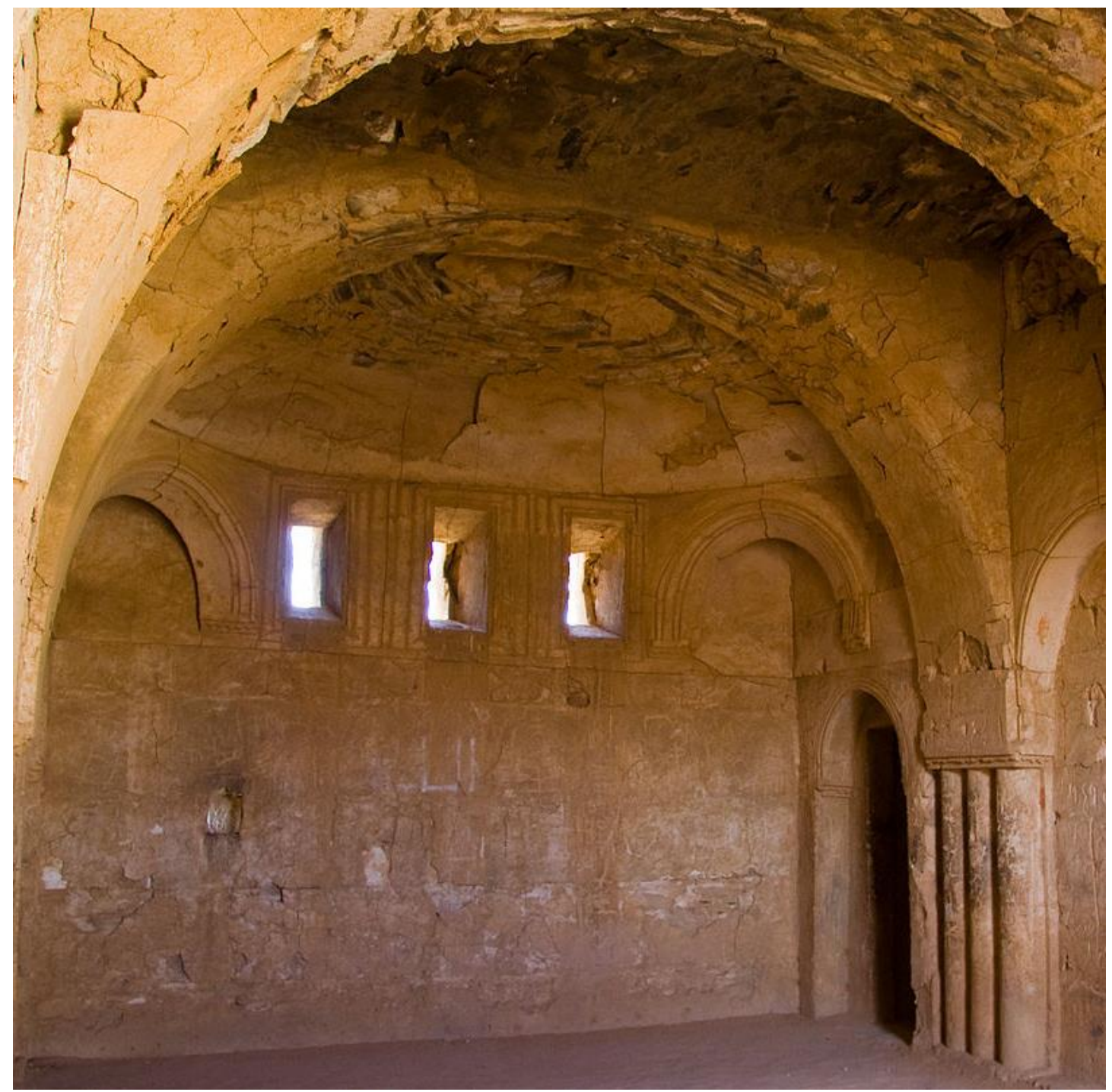

Figure 58: Flatted domes in Qasr Harranah, Source: Travelnas.com

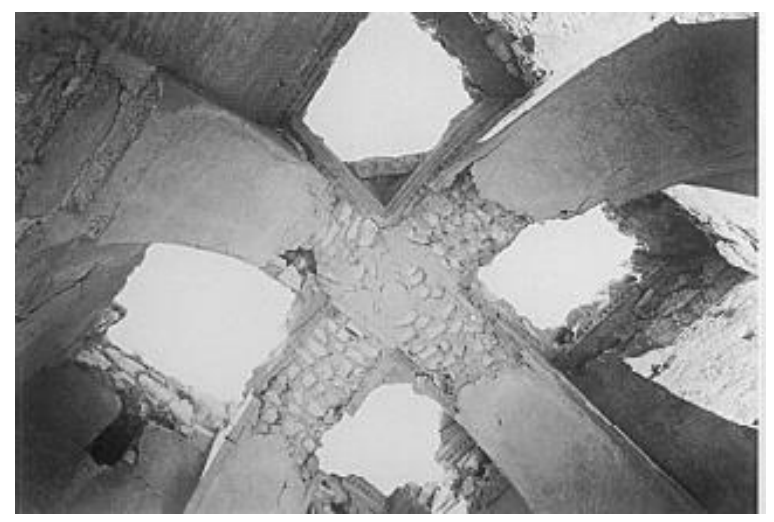

Figure 59: Cross Arches before restoration work.

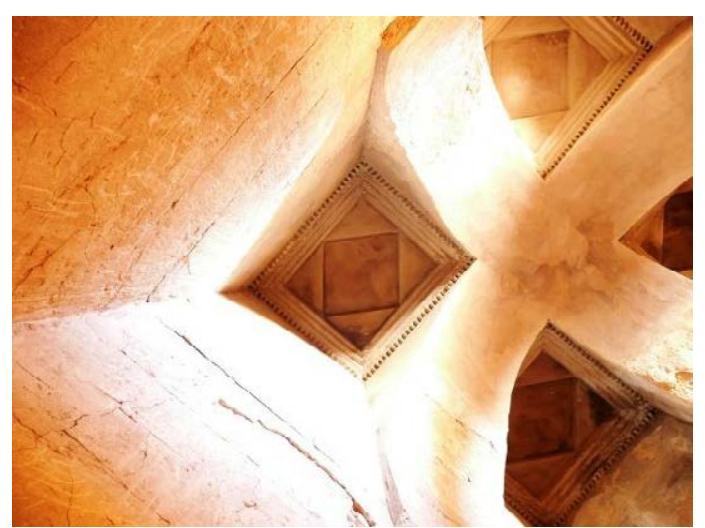

Figure 60: Cross Arches, After restoration work. Source: Army.arch 


\section{c. Qusayr Amra Vaults: 711-715 AD}

Quasar is an Arabic expression for a small Palace. The building was erected in the early eight century by Umayyad Caliph Al Walid I, Eastern Jordan [1]. It shows the influence of Roman-Byzantine Tradition in building [Figure 63]. It is an Umayyad bath complex famed for its painted frescoes. The complex contains several bath rooms with three parallel barrel vaults and a dome named as: "The dome of the sky". This Dome is laid out above the hot room of the castle bath [Figure 66]. It considered to have the oldest images painted on spherical Dome [Figure 69] [Figure 71]. Andrew Petersen in his book: 'Islamic Architecture Dictionary' mentioned describing:

The dome of the sky is painted with a representation of the zodiac. The zodiac representation is the earliest surviving example of a domed representation of the stars and is of fundamental importance to the history of science. (Petersen, 1996) [2].

He also explained the purpose of Qusayr Amra:

'Probably the most famous Islamic building in Jordan is the bath house of Qusayr Amra located west of Amman. The building stands alone apart from a small fort or caravanserai ${ }^{11}$ several kilometers to the north. Inside the building the walls and ceilings are decorated with a remarkable series of frescoes, including depictions of bathing women, a series of royal portraits, a hunting scene and the zodiac. Although the choice of pictures is certainly Umayyad the style of painting and the design of the bath house is purely Byzantine.' (Petersen, 1996) [3].
[1] AI Walid I, Is an Umayyad Caliph, who ruled from $705 A D$ until his death in $715 A D$
[2] (Petersen, 1996)

p. 138

[3] (Petersen, 1996) 


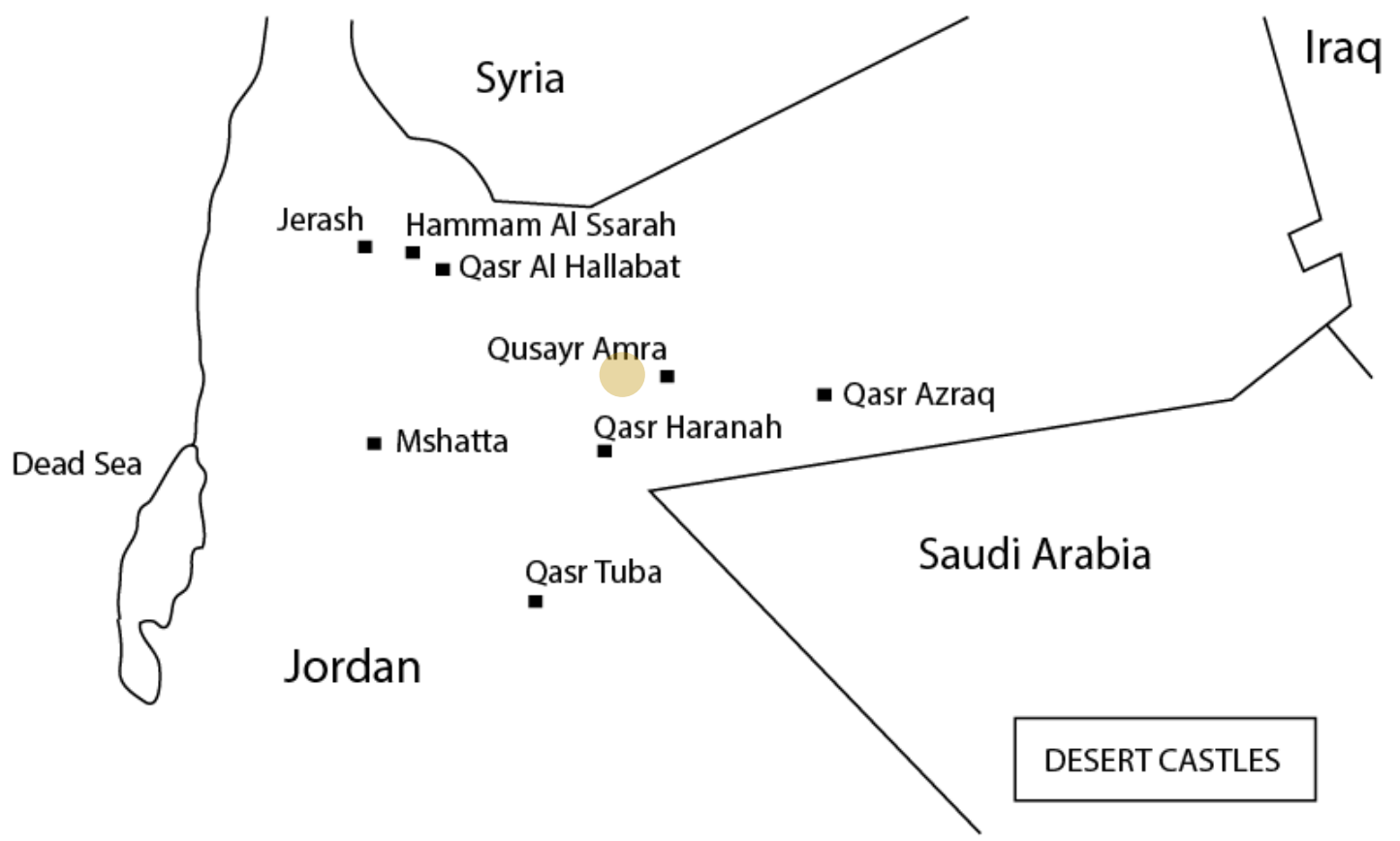

Figure 61: Qusayr Amra Location in Jordan , built during 711-715 AD
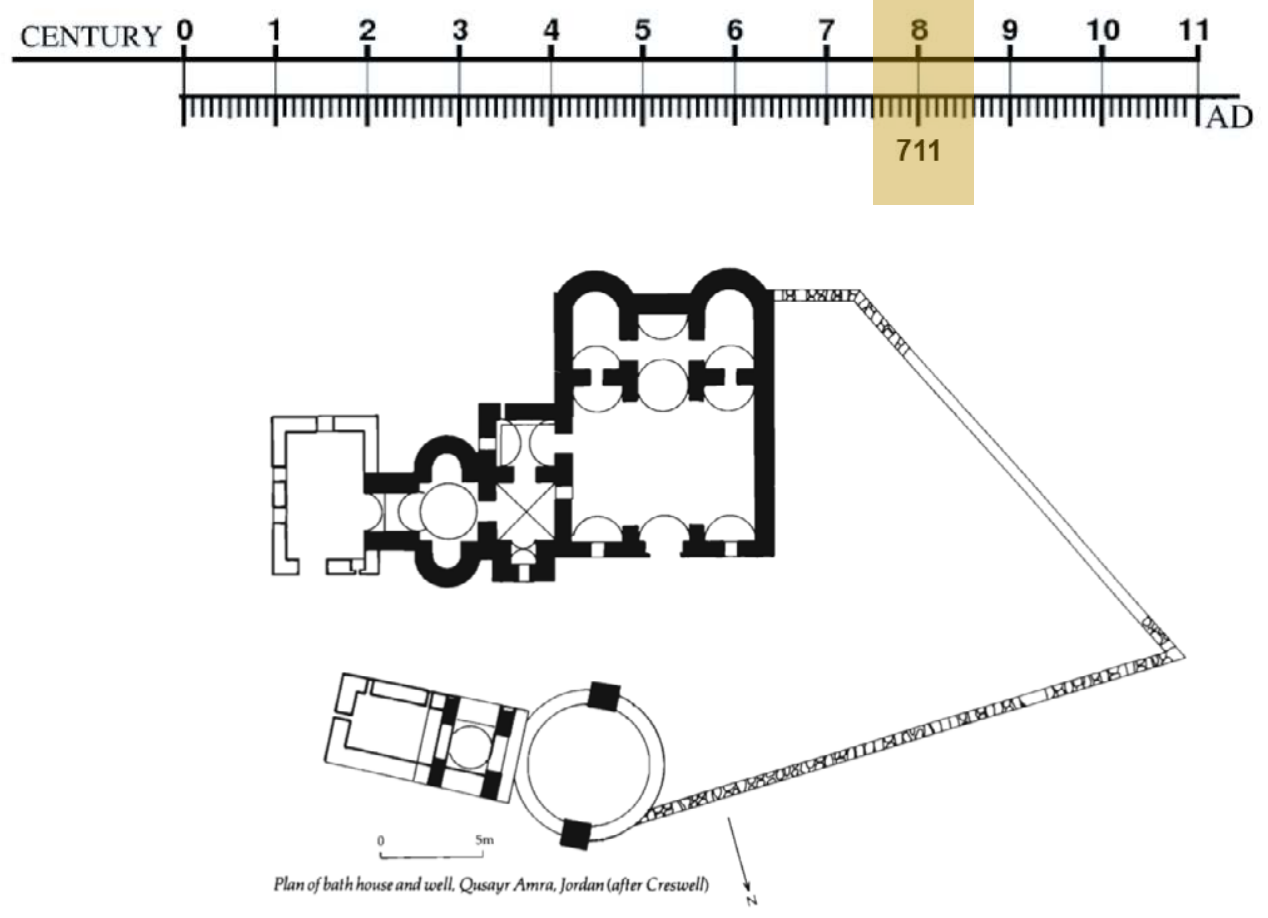

Figure 62: Plan of Qusayr Amra Bath House

Source: Archnet 


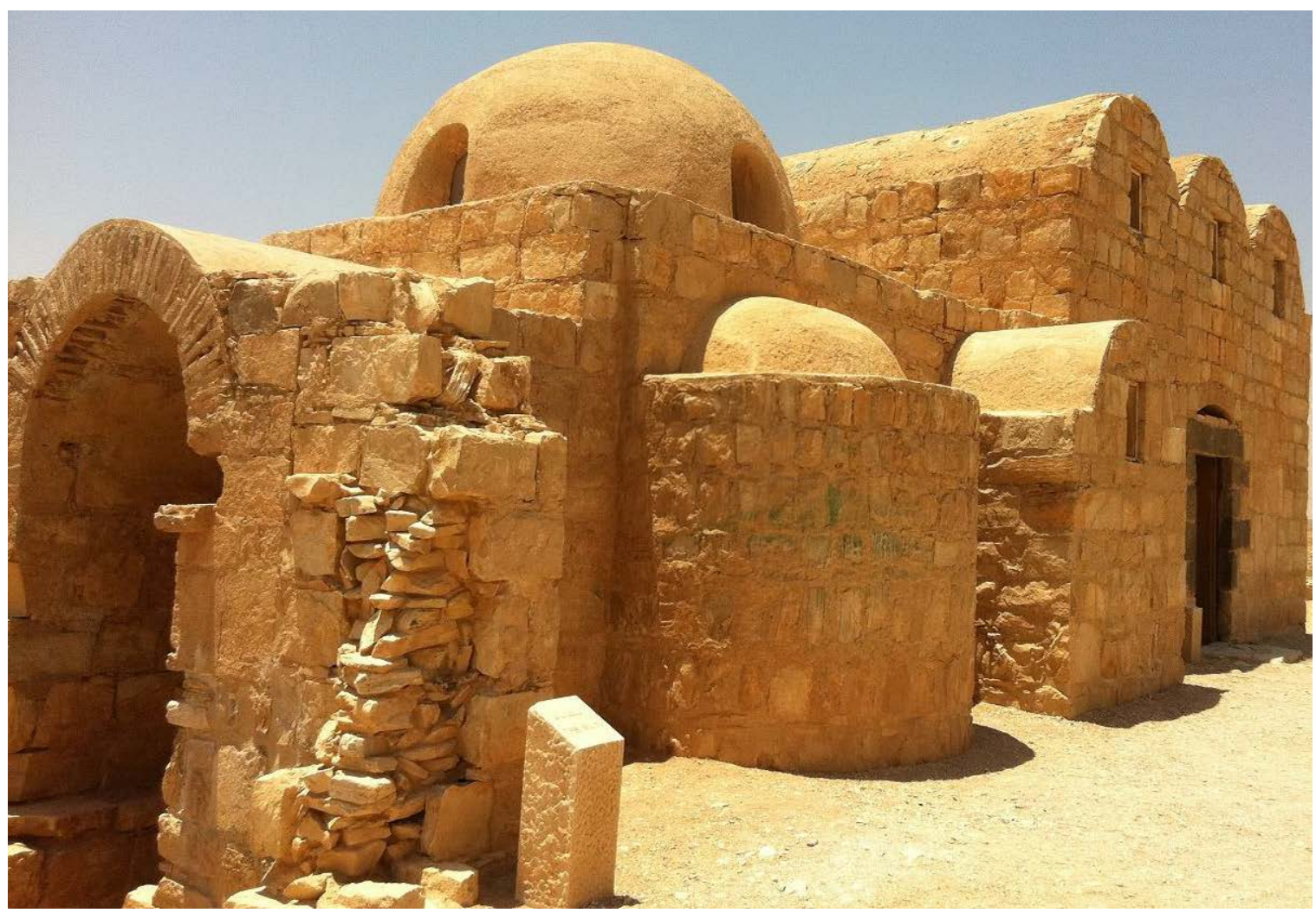

Figure 63: Qusayr Amra Vaults, Roman-Byzantine Tradition Source: By Rob

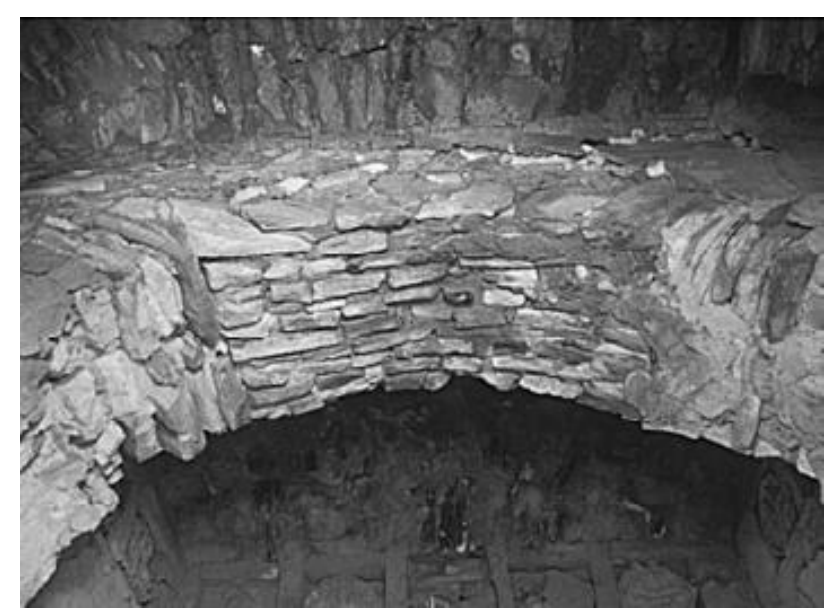

Figure 64: Qusayr Amra brick method Source: Arce

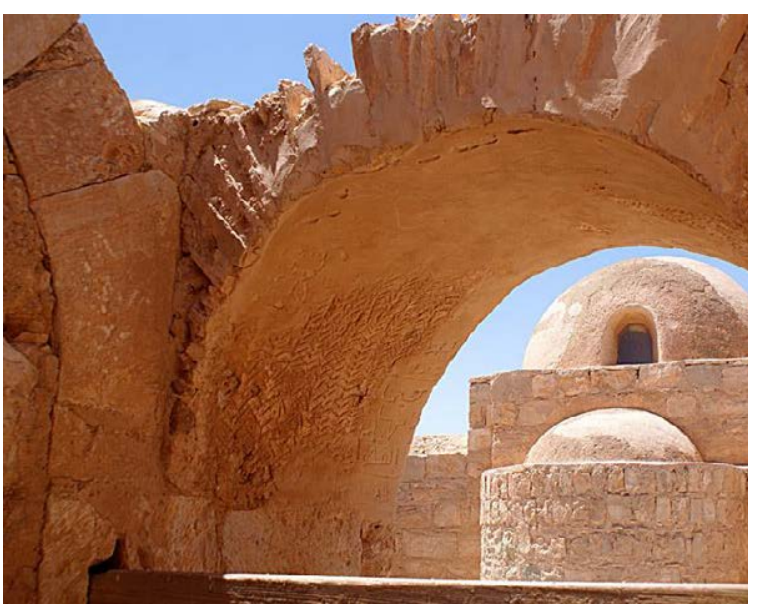

Figure 65: Qusayr Amra Brick Method Source: by Hadel Ramahi http://www.dpclick.com/en/Photos/Details/3067 


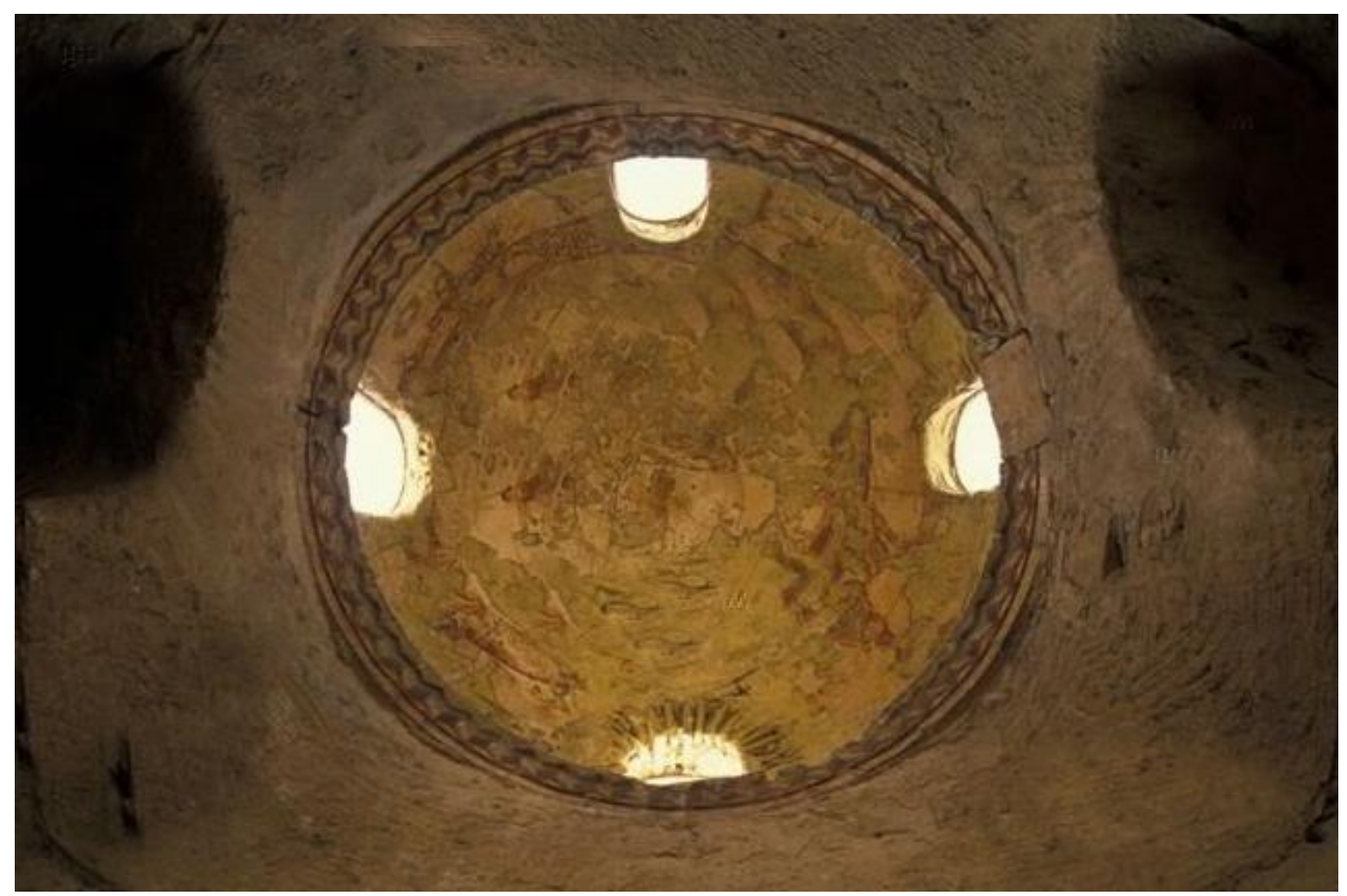

Figure 66: Qusayr Amra Vault, Dome of the sky or horoscope Dome.

Source: Almusafer

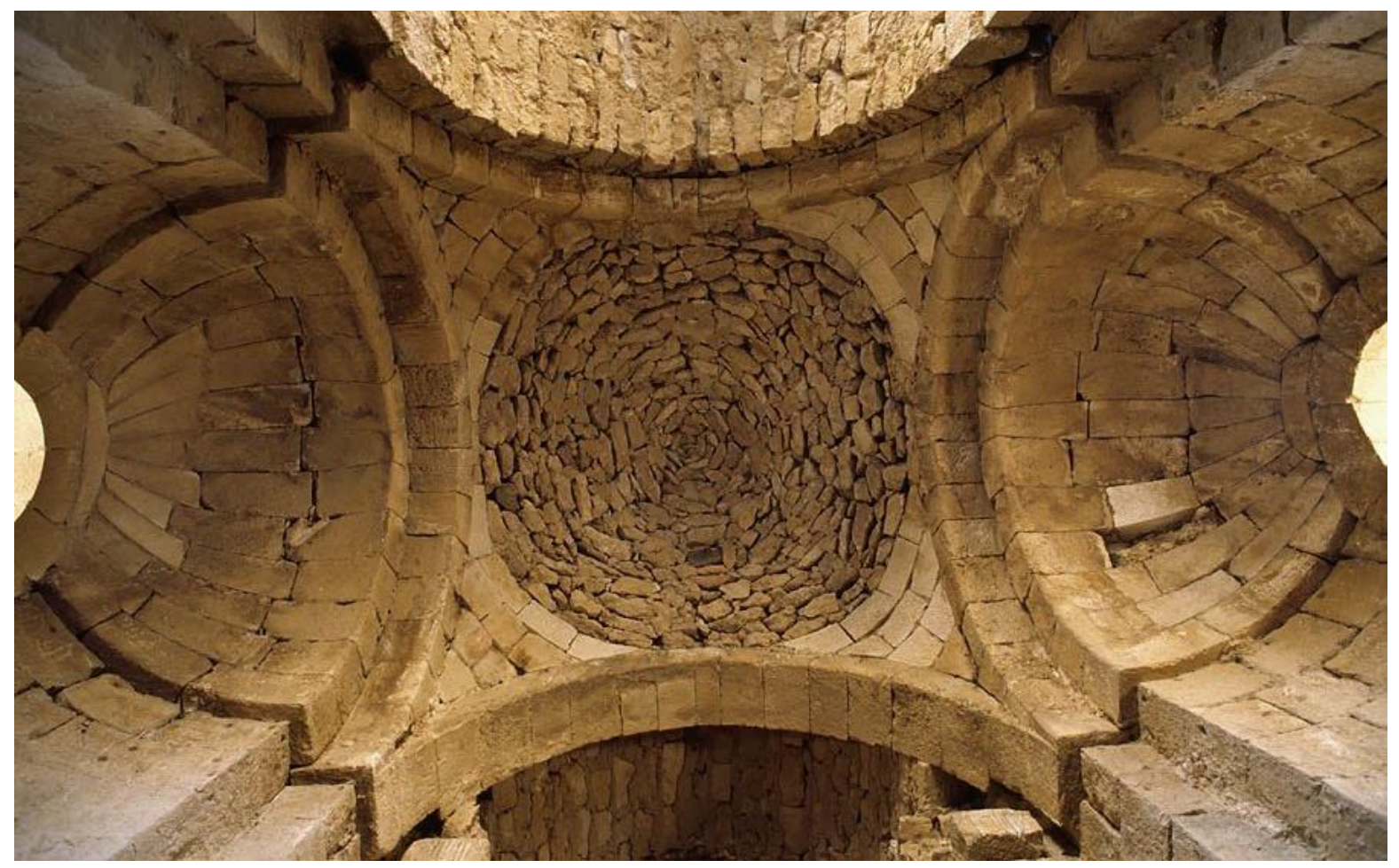

Figure 67: Qusayr Amra Vault,

Source: Stefan Sonntag 


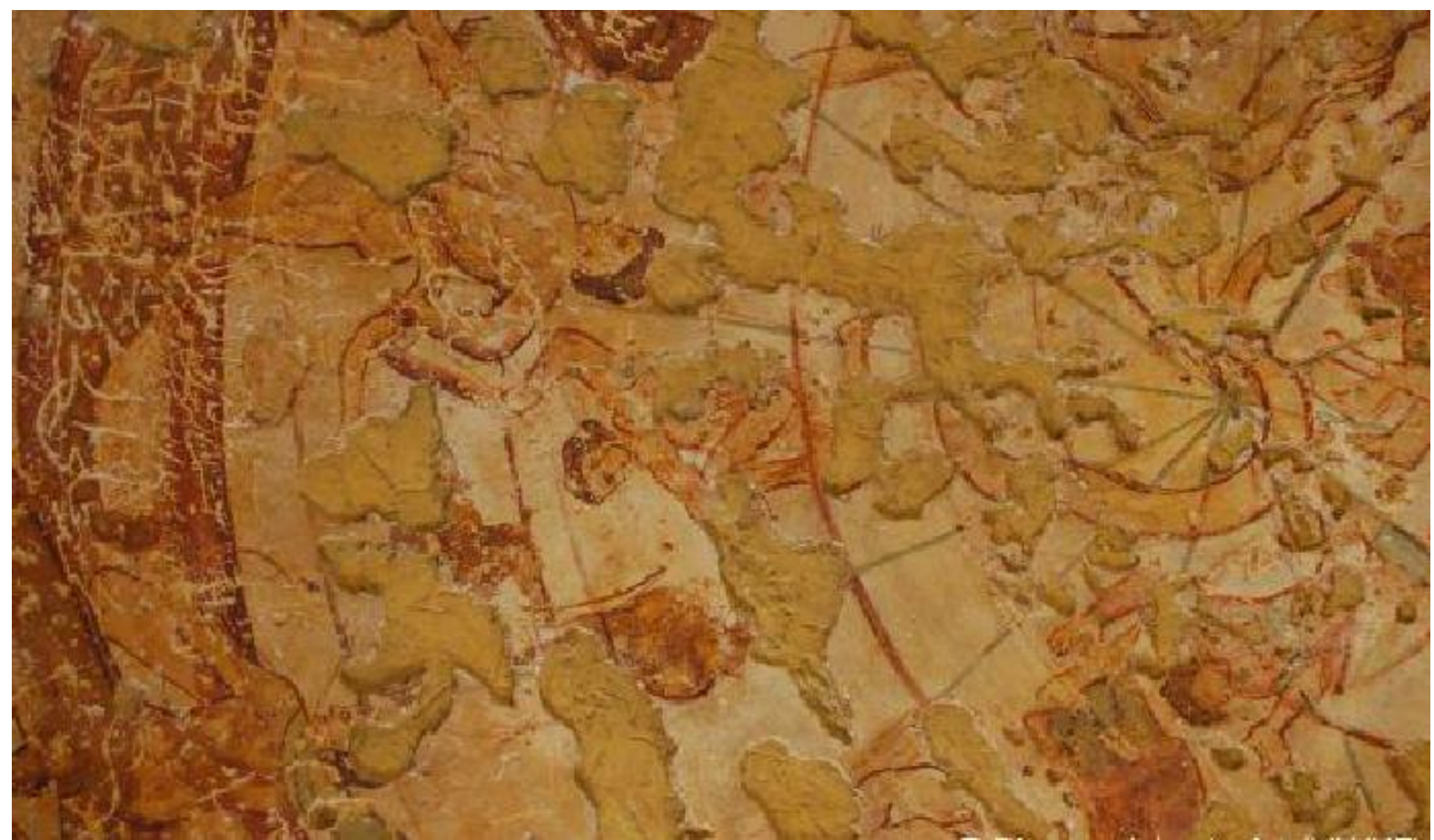

Figure 68: Close Shot Of Qusayr Amra Hot Room.

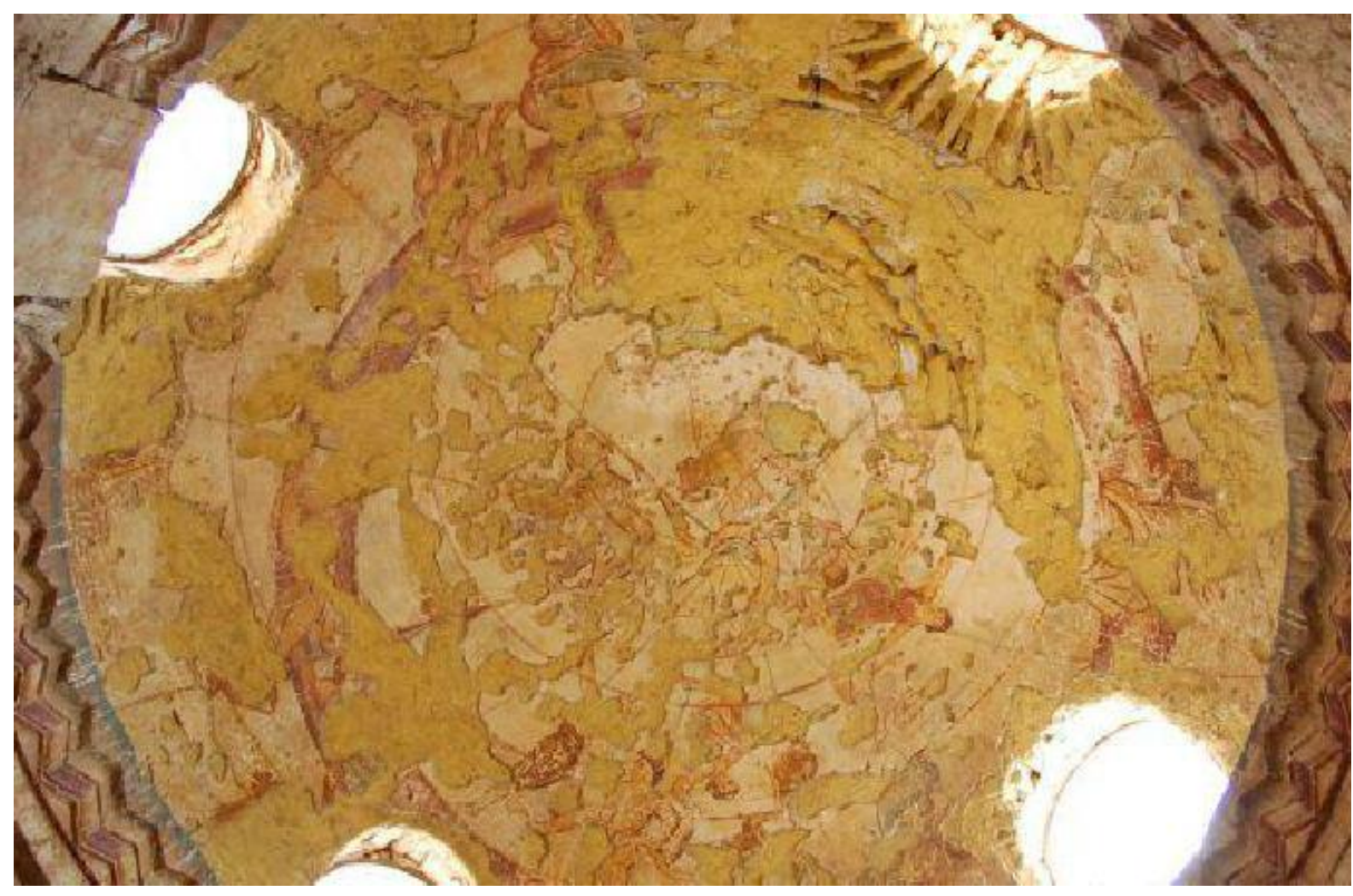

Figure 69: Qusayr Amra horoscope Dome or Sky Dome.

Resource: Discover Islamic Art 


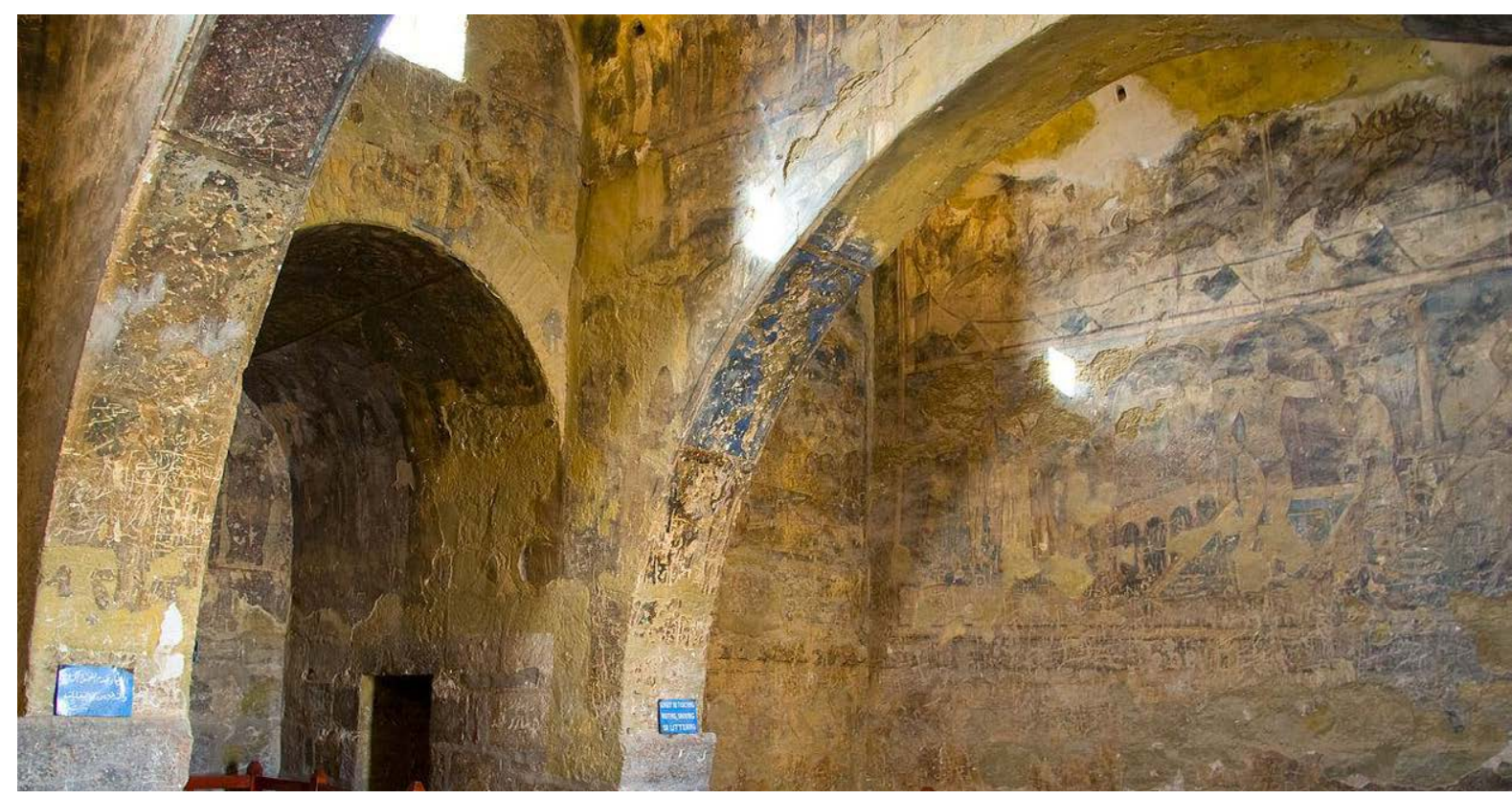

Figure 70: Qusayr Amra warm room, Source: by Source: Mohammad Abu Omar

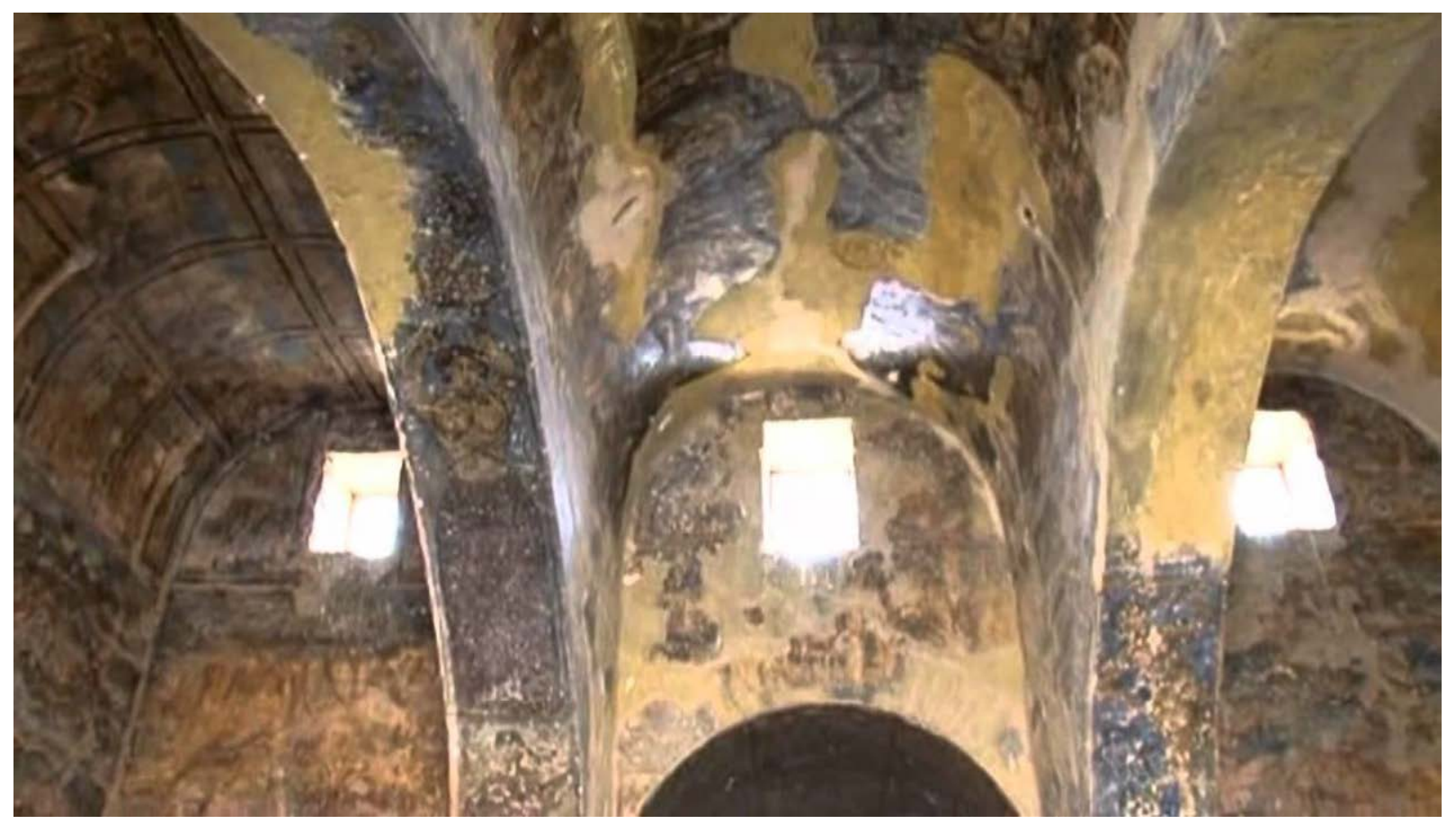

Figure 71: Qusayr Amra hall roof with three parallel barrel vaults Source: Mohammad Abu Omar 


\section{d. Qasr Al Mushatta Vaults: 744 AD}

Al Mushatta is one of the largest of all the Umayyad Palaces located in Southeast Amman [Figure 72]. The Complex was built during 743completed. Sources reported by Ibn Al Muqaffa' in 744 AD state that Caliph Al Walid II had collected workmen from all quarters for the construction of Al Mushatta [1] [2]. The outer enclosure is a square shaped building made of fine ashlar masonry with regularly spaced half-round buttresses and, on the south, a gate flanked by two semioctagonal towers [Figure 73]. The hall, of which the plan derives from the late Roman type, was flanked by four sets of four vaulted rooms around a court [Figure 74]. The walls, which rested on three courses of limestone masonry, were built of fired brick and supported slightly pointed pitched-brick vaults of Mesopotamian tradition [3]. The Mushatta was variously endorsed by the Ghassanid ${ }^{12}$ and the Lakhmid $^{13}$ dynasties in the VI century and then by the Sassanian occupation of Syria in the early seventh Century. Some scholars such as Creswell claimed that the adoption of such fortified buttressed enclosures for Muslim palaces is usually safe territory. Far from being an unstable frontier, is merely an imitation of the Roman limes or frontier forts which the Umayyads had occasionally occupied on the army route during their advance towards the East [4] [5]. Andrew Petersen analysed the Umayyads dessert castles influences describing them in his book 'Islamic Architecture Dictionary':

'Two buildings dated to the later Umayyad period [1](Ibn Al Muqaffa', 744)

[2] (Petersen, 2002). P. 140

[3] (Hillenbrand, 1999)

[4] (K. A. C. Creswell and James W. Allan, 1989)

[5] (Antiquities, 2001) (probably the reign of Walid II 743-4) represent a combination of eastern and western influences. The most obvious demonstration of these mixed influences is the use of baked brick for vaults and walls and

12 Group from the Southern Arabian Peninsula emerged to the Levant

13 Arab Christian kingdom which existed in Southern Iraq also called: Muntherids 
dressed stone masonry for foundations and architectural details. The most famous of these buildings is Qasr Mushatta.' (Petersen, 1996) [1].

The audience hall consists of triple combined rooms covered by large brick domes. The layout of the palace immediately recalls the Abbasid palace of Iraq, Al Ukhadir. Byzantine elements are also presented. The layout of the palace immediately recalls the Abbasid Palace of Iraq, Al Ukhadir. Byzantine elements are also present (Petersen, 1996).

'However, the most beautiful art in Mushatta Palace is the carved decoration in the limestone located in the entrance that resemble decorations Dome of the Rock [1] [2].'

\section{e. Qasr Tuba Vault: 774AD}

Qasr Tuba is located in Northern Amman [Figure 75]. The Palace is of Sassanid Influence built by using a combination of limestone and baked bricks [Figure 76]. The structure consists of two symmetrical enclosures joined through a long central corridor. The enclosure walls are supported by semi-round towers, except on the north side where the two gateways are flanked by two square rooms. The north-western section is nearly intact and several lengths of curtain-wall exist on the western side.
[1] (Petersen, 1996) P. 140.

[2] These pieces had been transferred to the Department of Islamic Art in Berlin Museum. The Ottoman Sultan Abdul Hamid in 1903 AD decorations donated the palace to the Kaiser William II of Germany, and this is why there are motifs facade in Germany. 


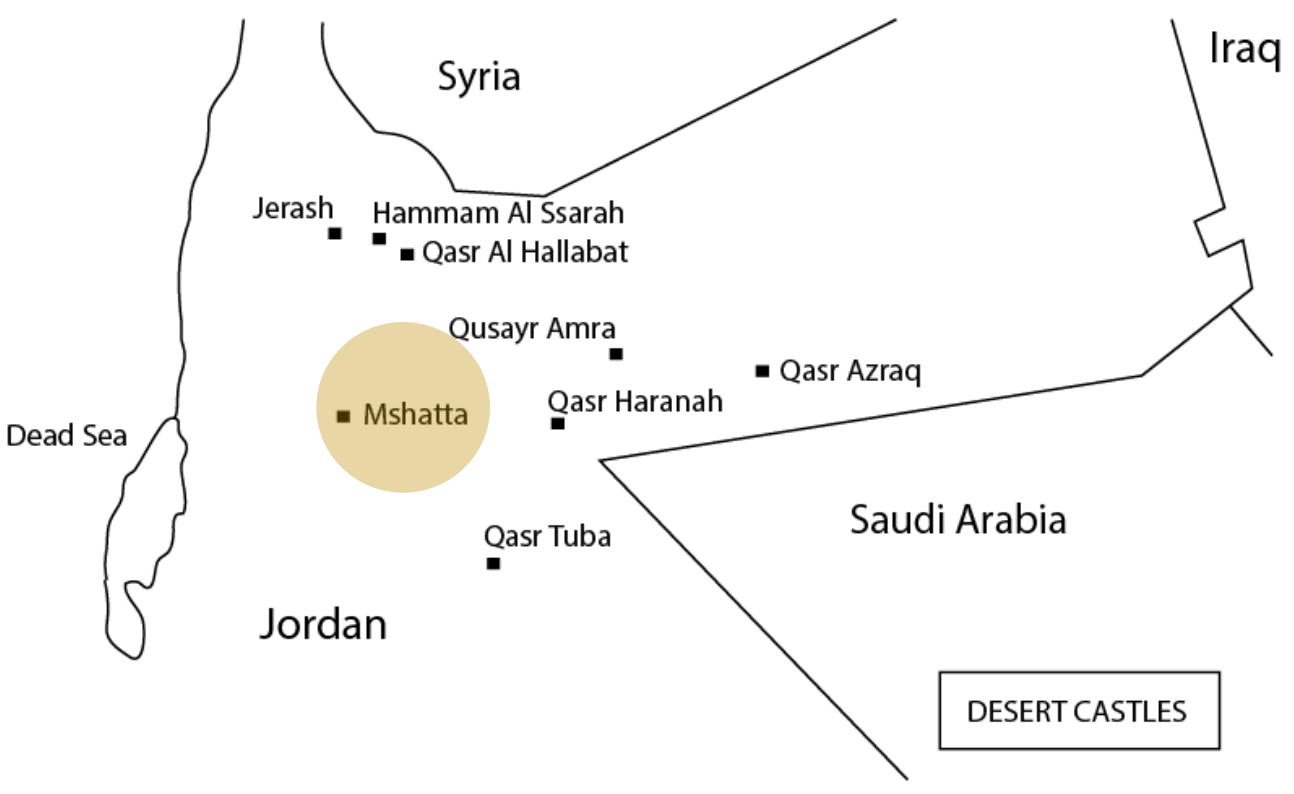

Figure 72: Qasr Al Mashtta Location

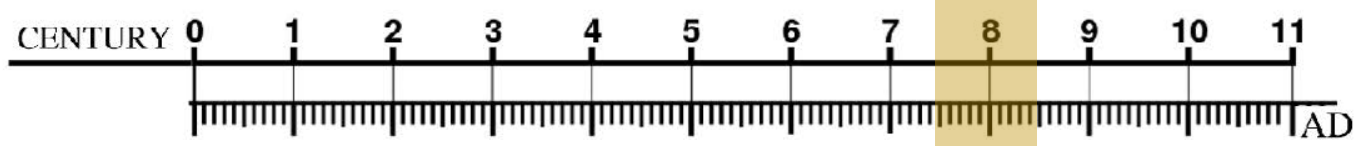

744

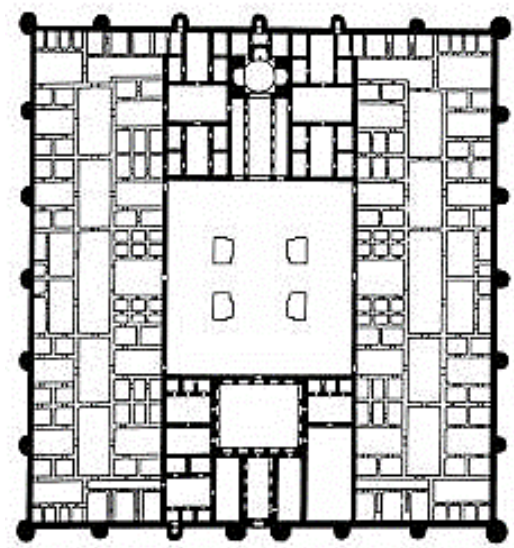

Figure 73: Qasr Al Mshatta Plan, 744 AD

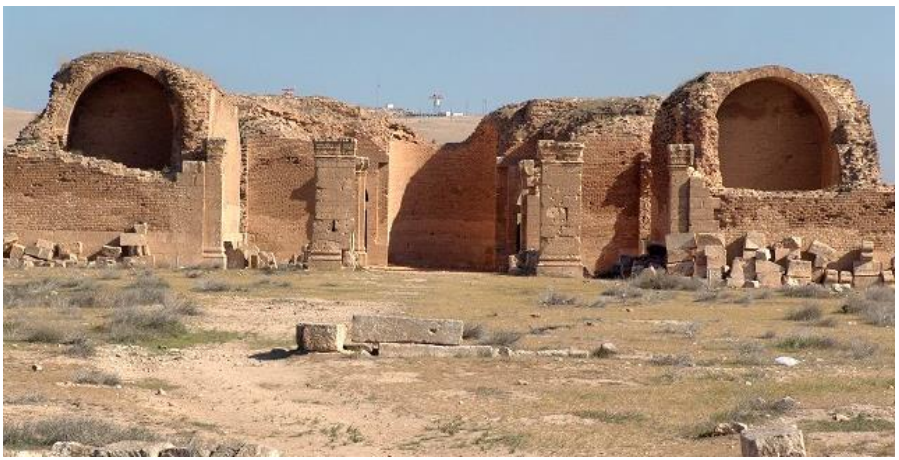

Figure 74: Qasr Al Mshatta, Sassanid Influence, 744AD

Source: Archnet 


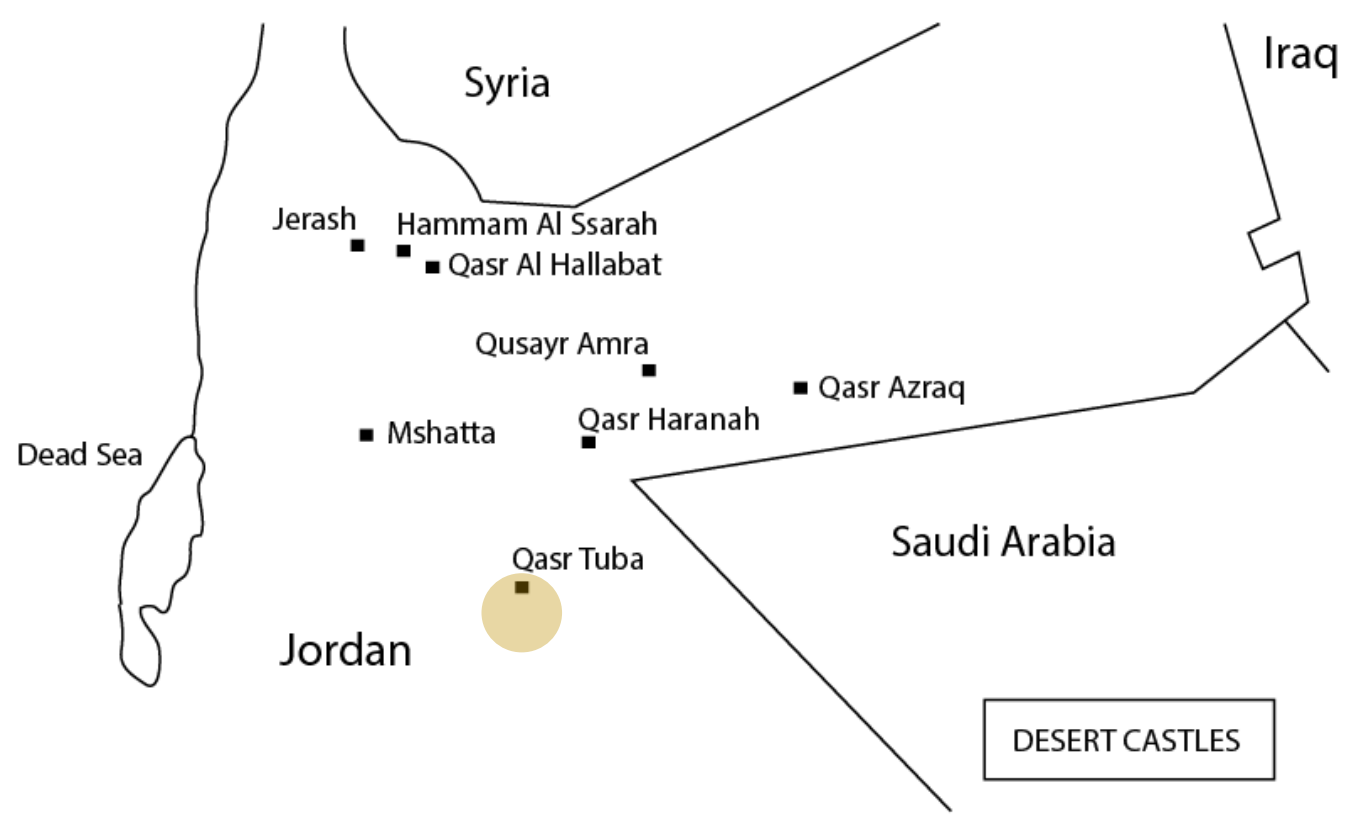

Figure 75: Qasr Tuba Location
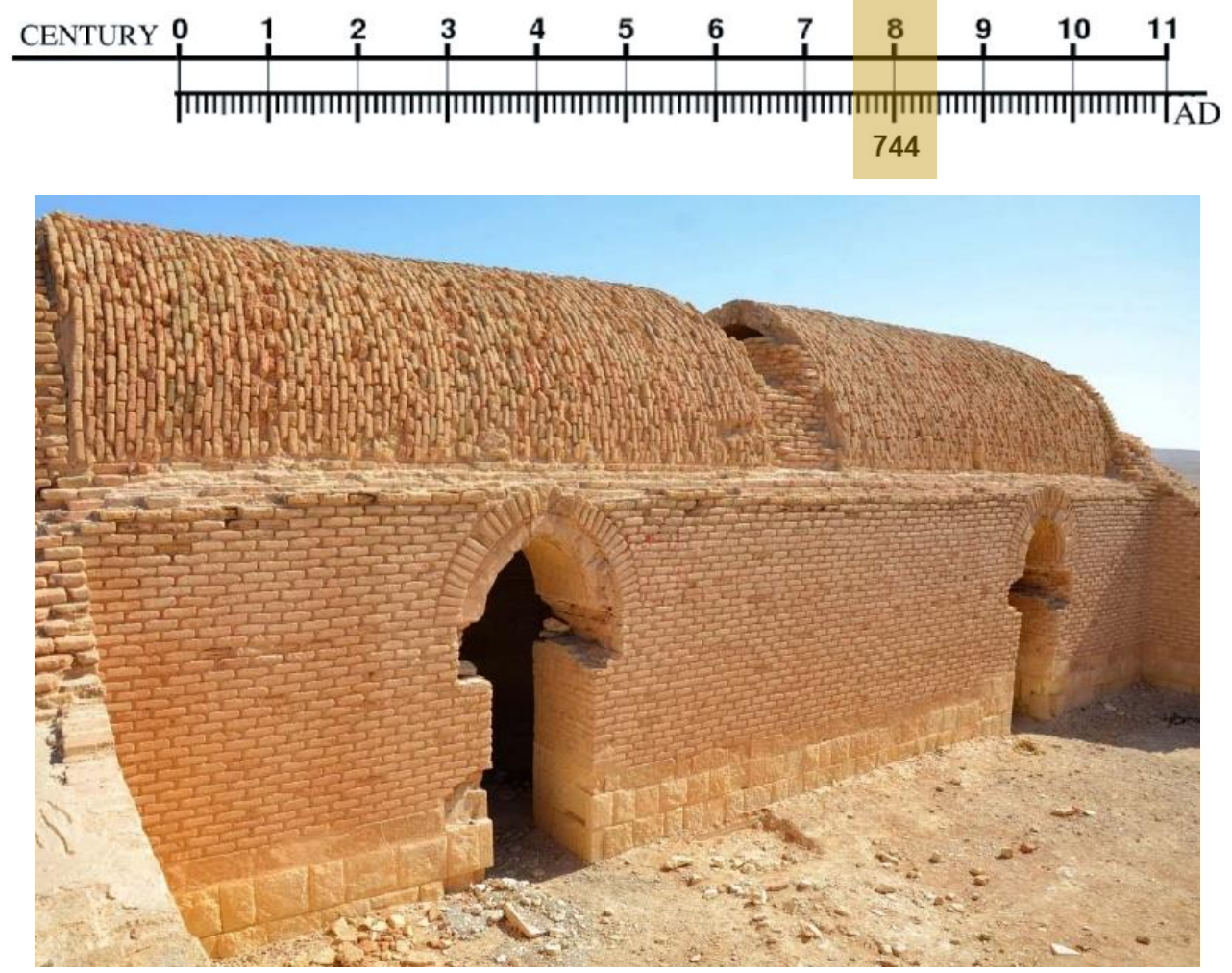

Figure 76: Qasr Tuba Vault, source: Belal Natoor 


\section{f. Qasr Hallabat Complex Vaults: III century}

In North Western Jordan, a Roman tradition complex was built and restored in 529 AD. Several complexes were located in the same area [Figure 77] [Figure 78]. Arab Scholars refer the building to The Nabataean period while western historians define it as a Roman fortress [1] [2]. Nevertheless, by the VIII Century, Umayyad Caliph, Hisham Ibn Abdul Al Malik, made an order to demolish the Roman fortress and redevelop a military site for Umayyads to become one of the biggest Umayyad Desert complexes. Guided by the existing plan, he incorporated a mosque. Qasr Al Hallabat was originally built in the II century $A D$ and later restored in $529 A D$. During the Umayyad residence the mosaics, painted plaster, frescoes, carved, painted wood, floral, animal motifs and finely carved stucco with geometry were added [3]. To the east of the castle was a rectangular roofless mosque with three entrances and Mihrab in the south wall [Figure 80] [Figure 81]. The Mosque was decorated with stucco work. Located approximately three $\mathrm{km}$ to the south of Hallabat is a bath house similar to Qusayr Amra in design.

In 1996, Andrew Peterson had described:

'Whilst the particular combination of structures and design is characteristic of Umayyad period, the individual elements and building style at Hallabat are all Byzantine.' (Petersen, 1996) [4].

And added:

'The main palace is constructed of black basalt and limestone. Full-stone masonry barrel vaults of Late Roman tradition were part of the construction [5].'
[1] Although there is trace evidence of Nabatean presence at the site. It was one fort of many on the Roman highway, Via Nova Traiana, a route that connected Damascus to Aila (modern-day Aqaba) by way of Petra and Philadelphia (modernday Amman). (Wikiwand, 2016)

[2] A Latin inscription founded refers to the construction of years 212-213 AD at the time of the Emperor, Krakla. Another inscription refers to the year $529 A D$ during the Byzantine period. It is believed that the dates refers to the restoration of the palace during the Byzantine period. (Holland and Urban, 1992).

[3] (Holland and Urban, 1992).

[4] [5] (Petersen, 1996) p. 138 


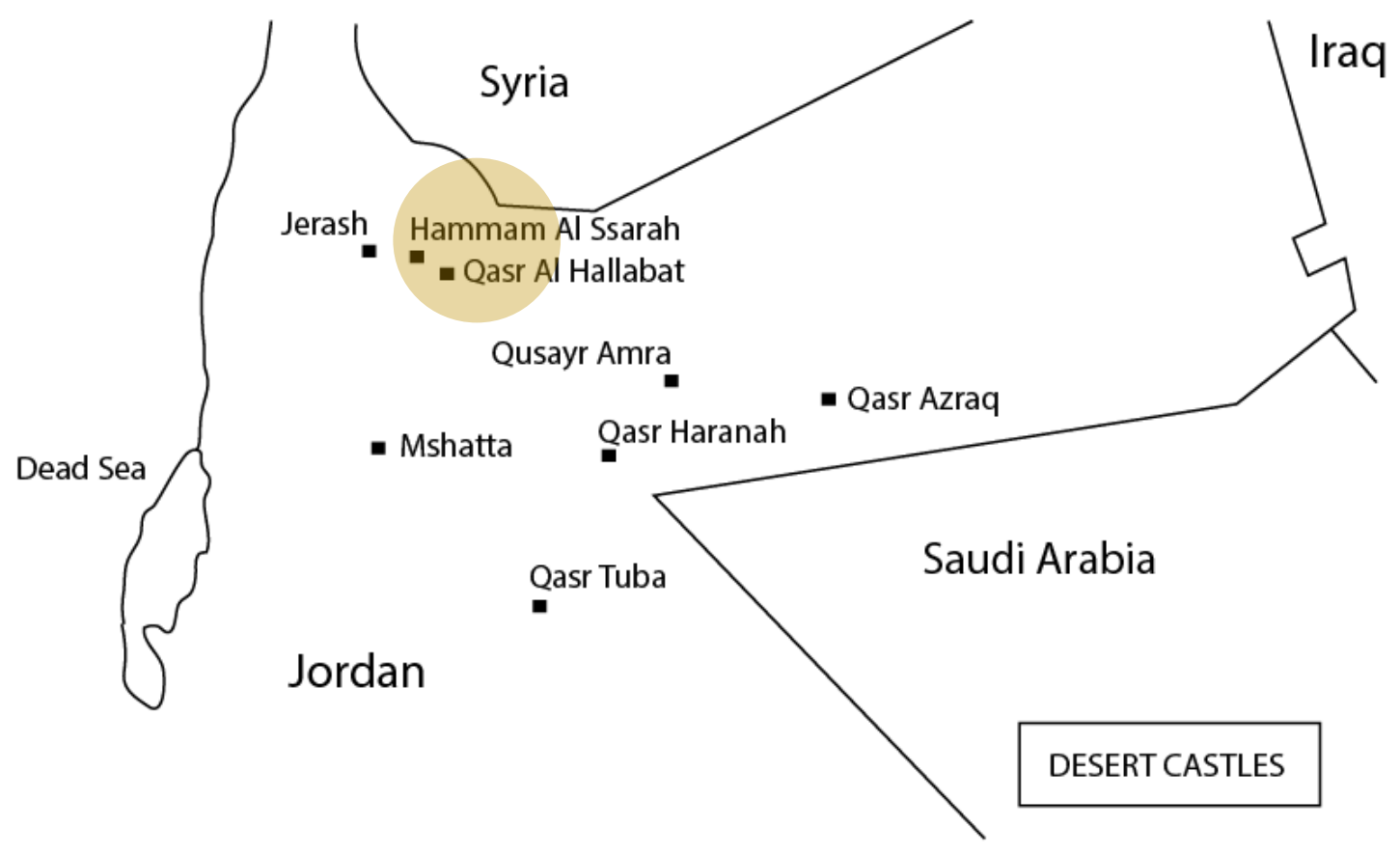

Figure 77: Hallabat Complex and Hammam AISarah Location
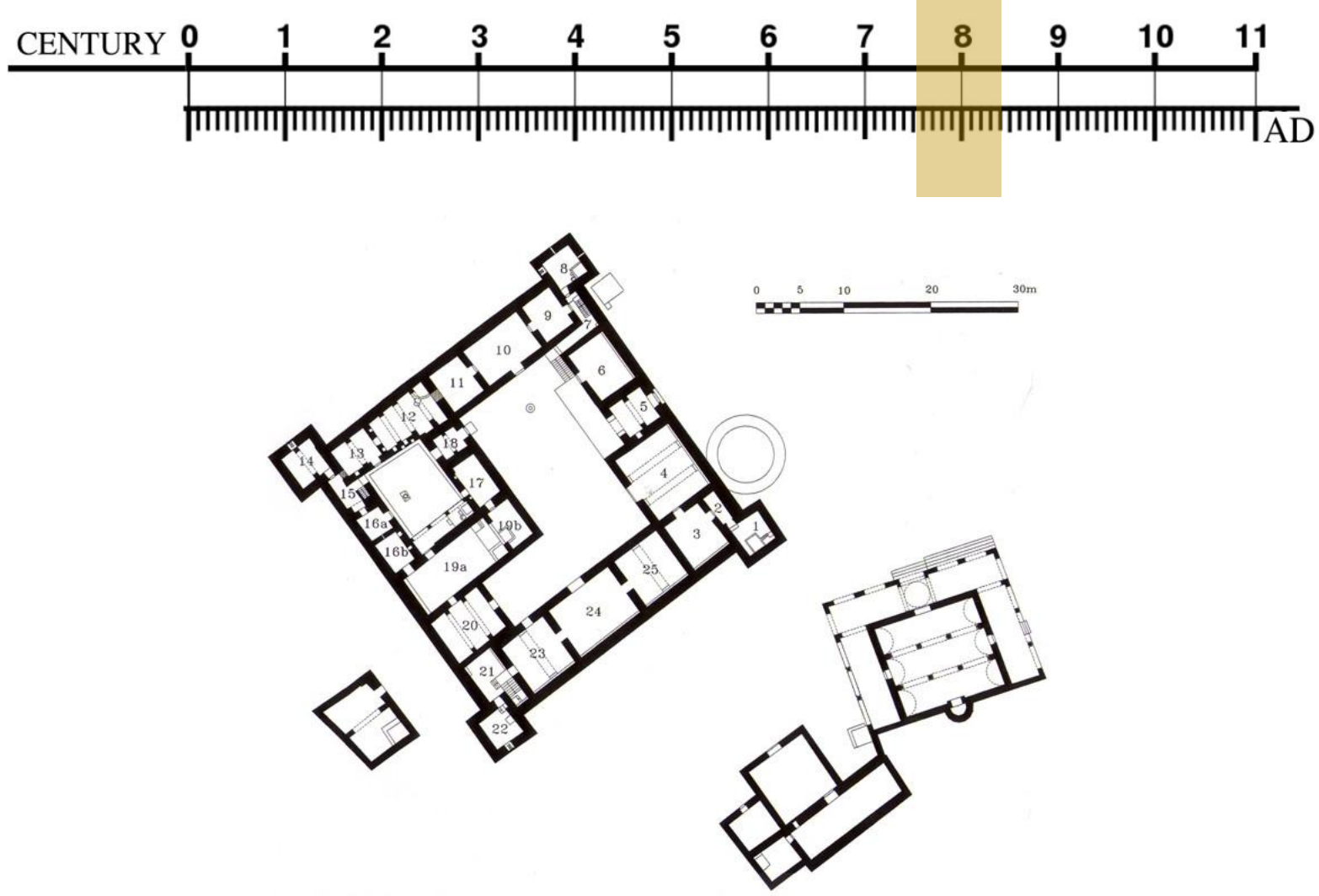

Figure 78: Hallabat Complex Plan, Mosque and Hammam

Source: Archnet 


\section{g. Hammam Al Sarah Vault}

An Umayyad bathhouse connected to Qasr Al- Hallabat complex named as Al Sarah

Bathhouse was located 2 kilometres to the West. Its design shows similarities to the design of Qusayr Amra. The baths comprise of an Apodyterium, which means the undressing room. a Tepidarium, which means warm room and the caldarium, which is the hot room.

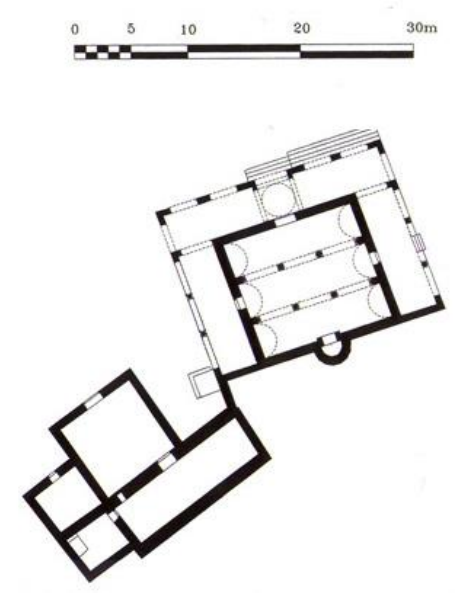

Figure 79: Hammam Al Sarah Plan

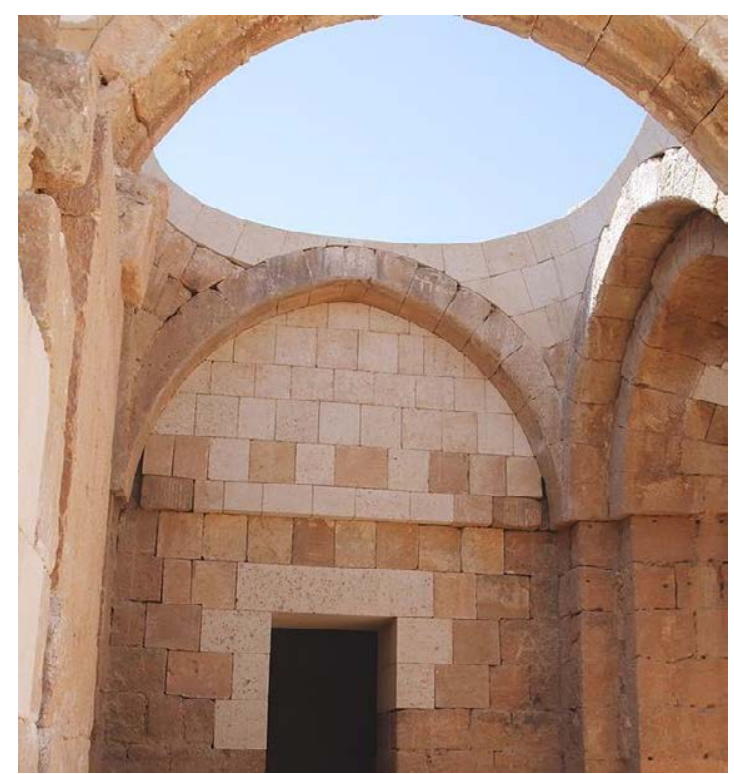

Figure 80: Hammam Al Sarah while restoration

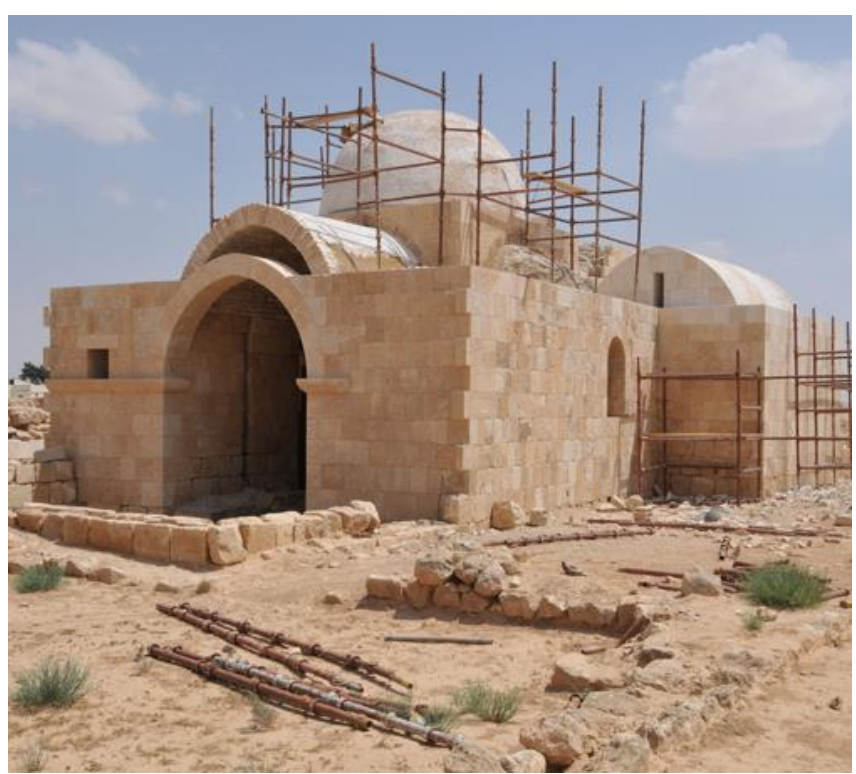

Figure 81: Hammam Al Sarah, after restoration

Source: Archnet 


\section{h. Khirbat Al Mafjar Vault: 724 - 743 AD}

Khirbat Al Mafjar is located near Jericho in the Jordan Valley [Figure 82]. It remains one of the most sophisticated Umayyad Palaces that is listed among the last of the surviving antiquities of both The Romans and Byzantines. It was built by Walid Ibn Yazid in 734 AD during the Caliph Hisham Ibn Abdul Malik Period who ruled between 724-743AD. It is famed for its decorations that represented the illustrations of the early Islamic classical art. Al Mafjar was built mainly of sandstone highlighted at times with baked-brick. The complex encompasses three main areas including a two-storied Palace a mosque accompanied by a small courtyard, a bath and an audience hall. The significance of this building can be seen in various levels. The geometrical pattern of both plan and elevation reflected a new approach to the Umayyad Era. The main gate of the complex is centrally located on the southern facade of the Palace and is flanked by two buttress towers at each edge of the front of the structure. The structural aspects of Khirbet Al Mafjar reveal an elaborate use of the vaulting system involving the dome and barrel vaults [Figure 84] [1] [2].

[1] (FSTC, 2016)

[2] (Archnet, 2016)

Khirbat Al Mafjar is an evidence of Byzantine and Sassanian influence respectively, that adorn the audience hall and bathhouse. At Khirbat al Mafjar there are examples of cross vaults and domes on pendentives built in this mixed brick-stone masonry (Hamilton 1959) [3].

The Palace itself features a central courtyard. This court faces the Hammam to the north and a small mosque to the East. Khirbat Al Mafjar is renowned for the mosaics and stucco carvings, evidence [4] (Blooms, 1995) of Byzantine and Sassanian influence [4]. During this period Syria widely respected local tradition of mosaic production, stucco and introduced it to the Sassanian Traditions. 


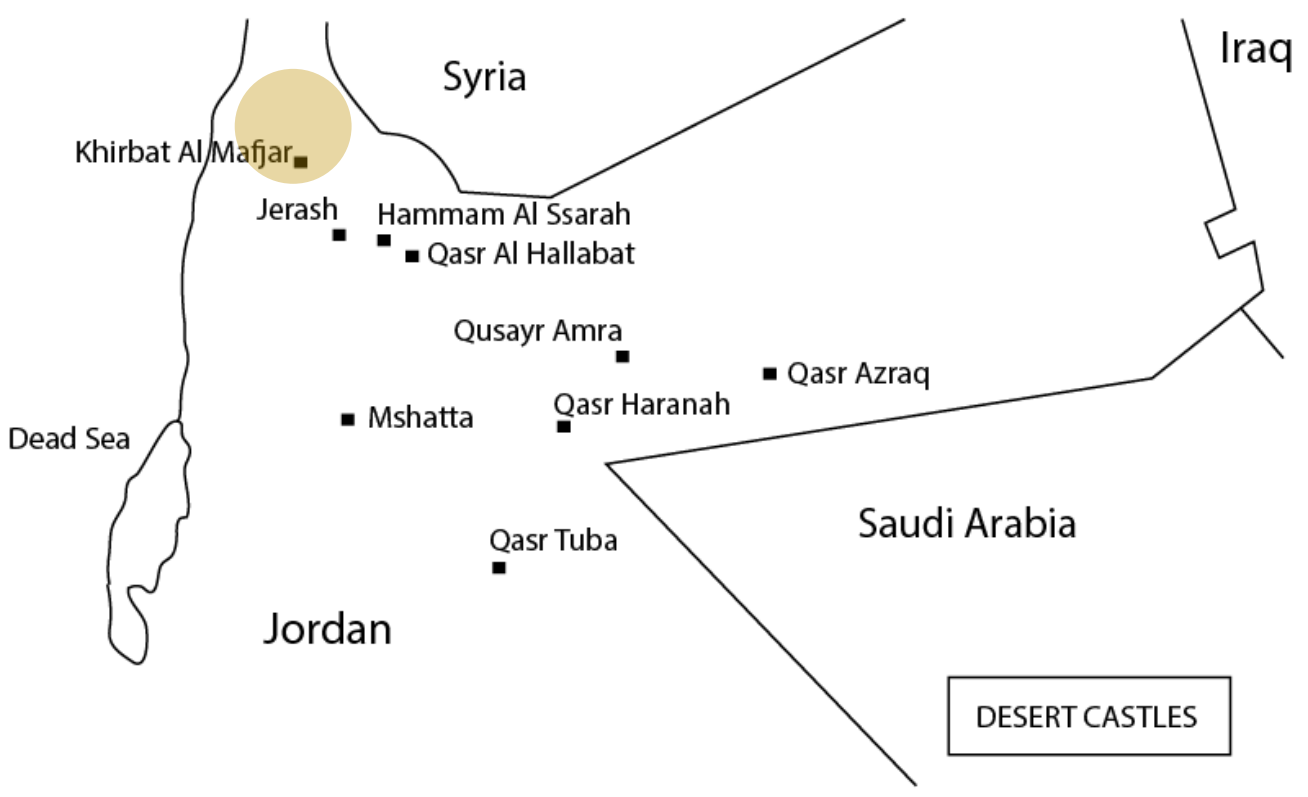

Figure 82: Khirbat Al Mafjar Location, Built 734 - 744 AD

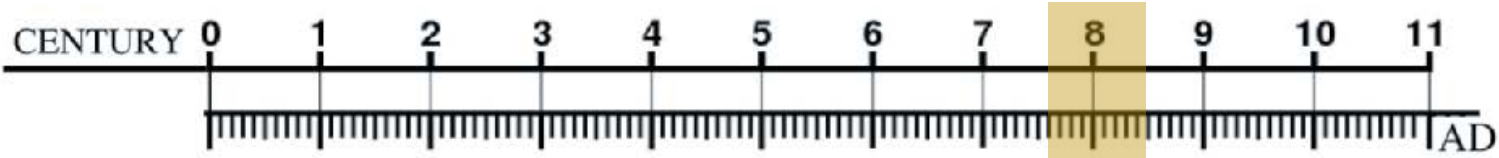

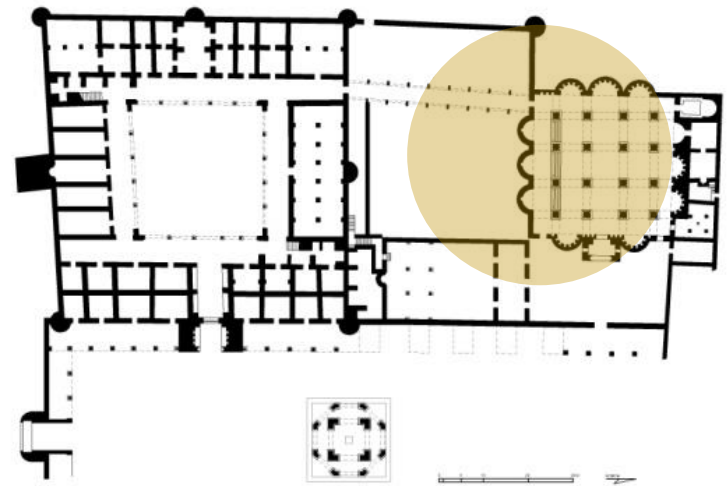

Figure 83: Khirbat Al Mafjar Plan

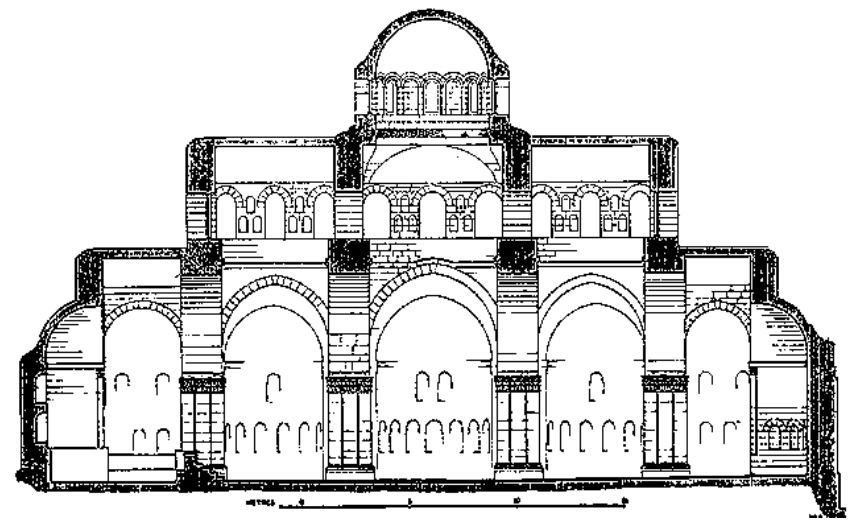

Figure 84: Khirbat Al Mafjar

Source: FSTC 


\subsubsection{List of Umayyad Dessert Castles}

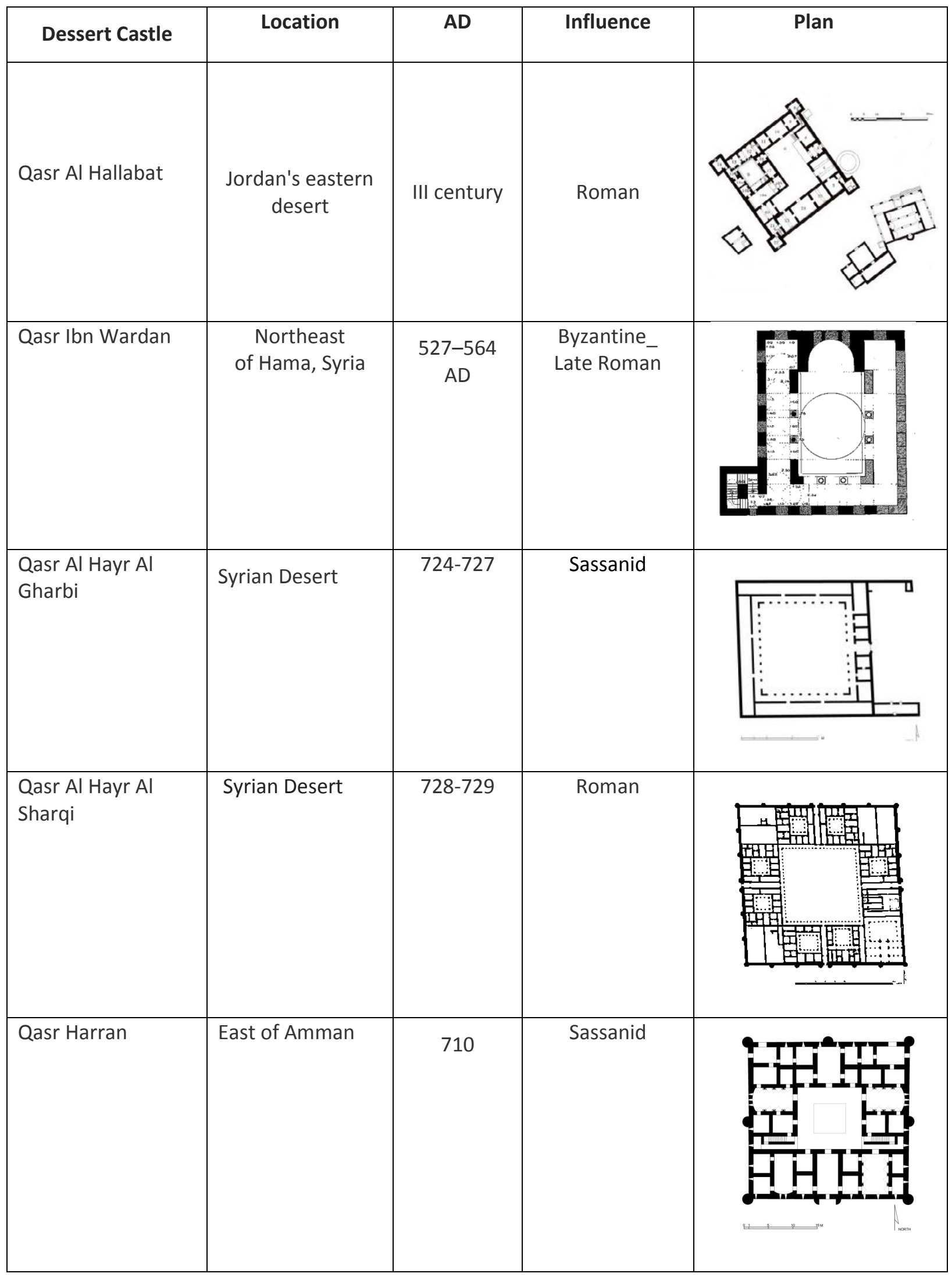




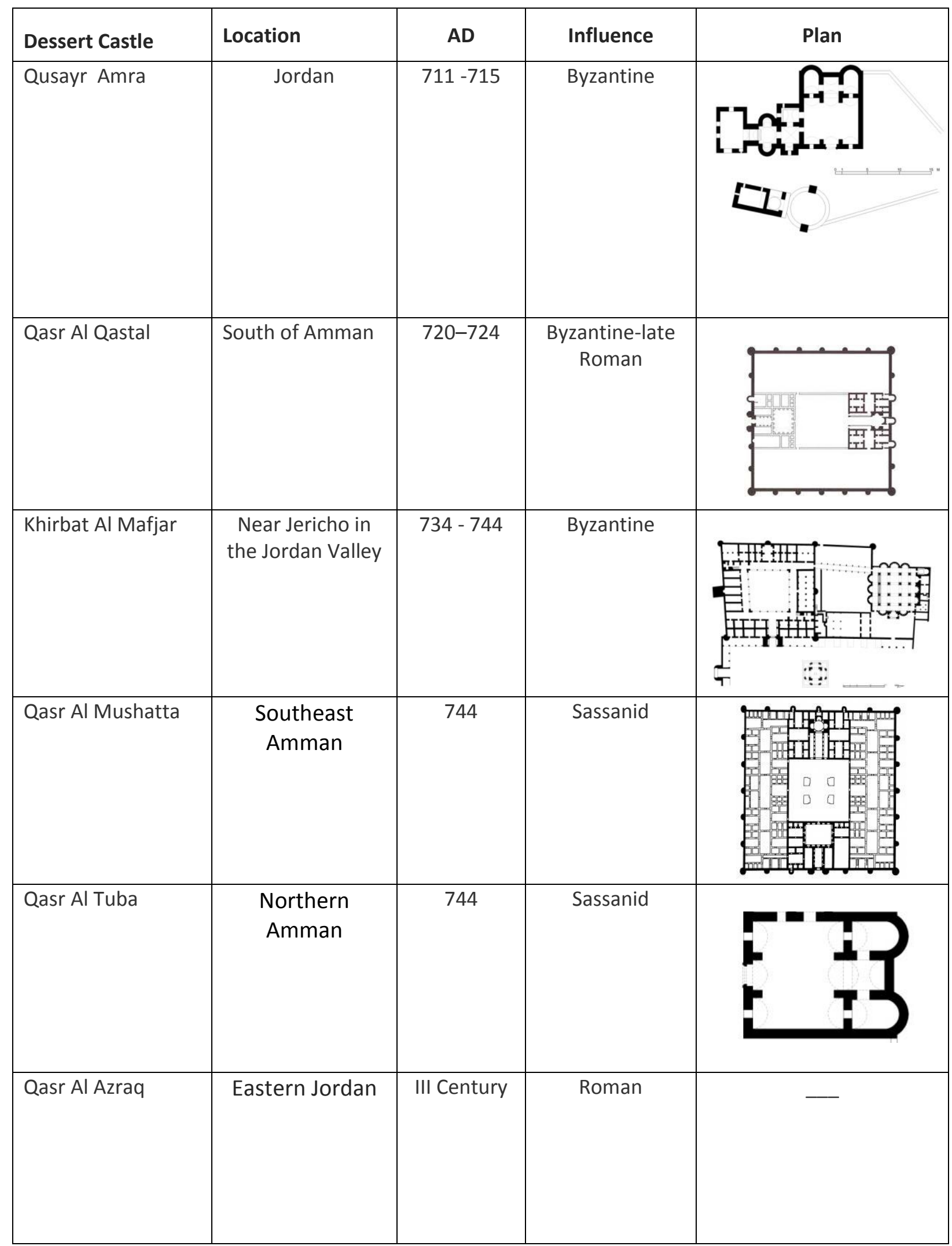

Table 2: Umayyad Dessert Castle Plans 


\subsubsection{Type of Vaults in Umayyad Dessert Castles}

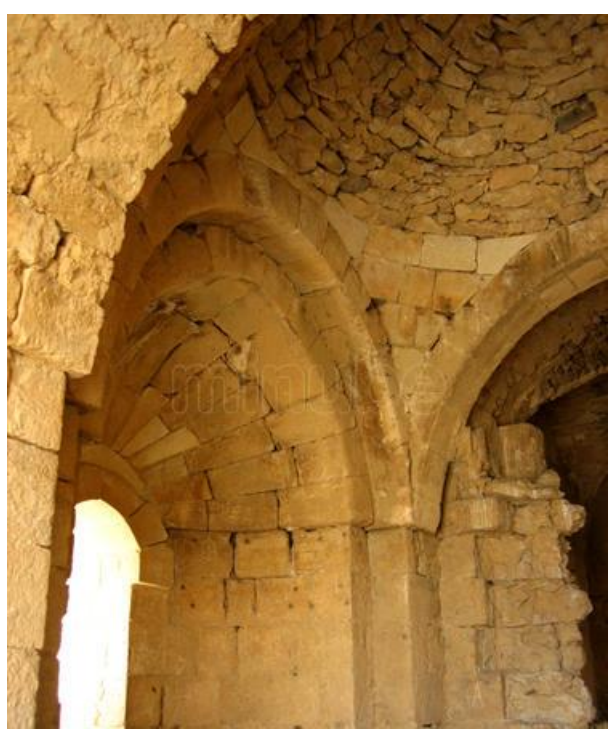

Figure 85: Byzantine Tradition

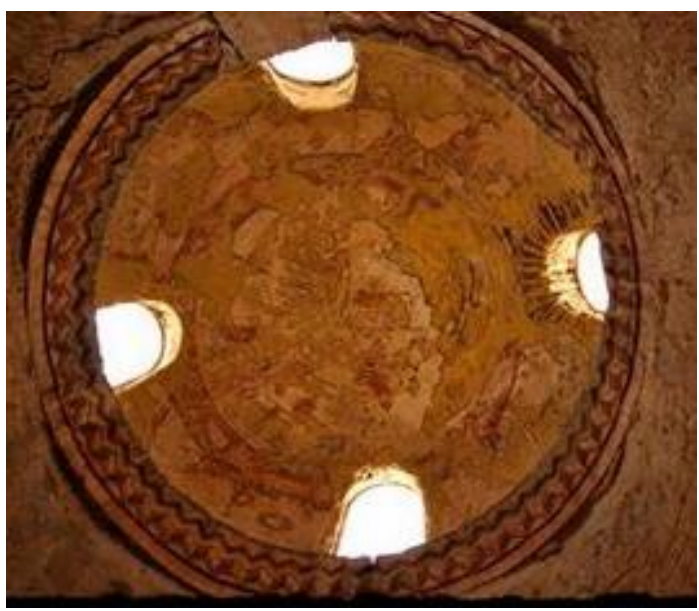

Figure 87 :Byzantine Tradition

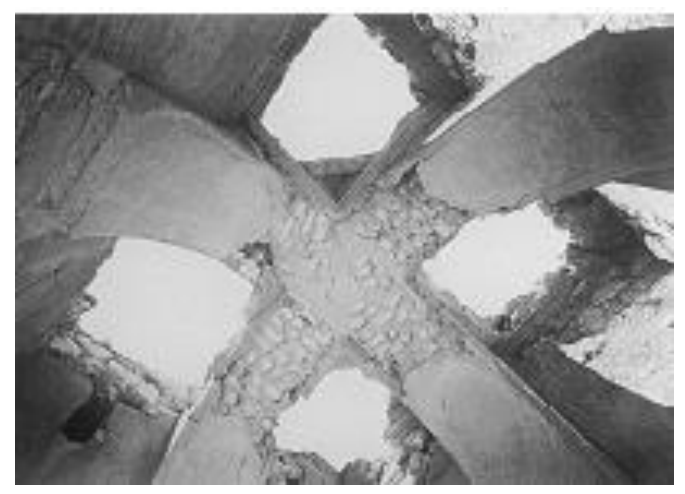

Figure 89: Umayyads Tradition

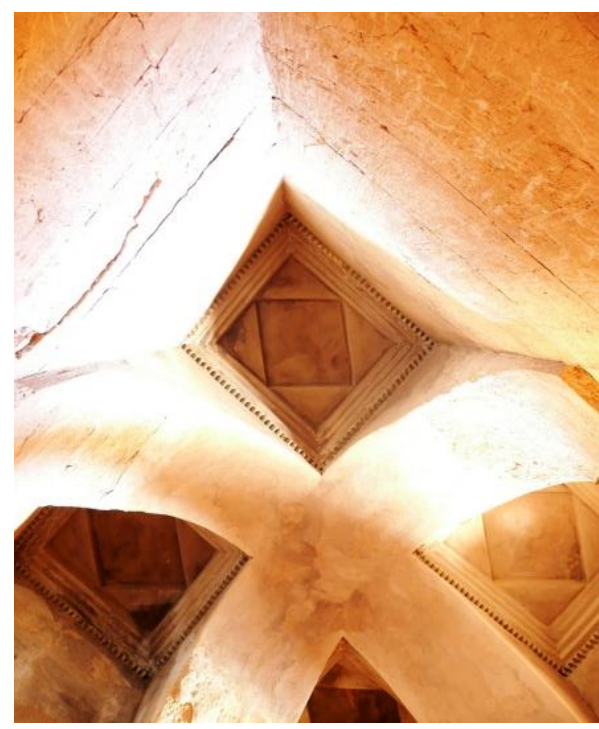

Figure 86: Umayyad Tradition

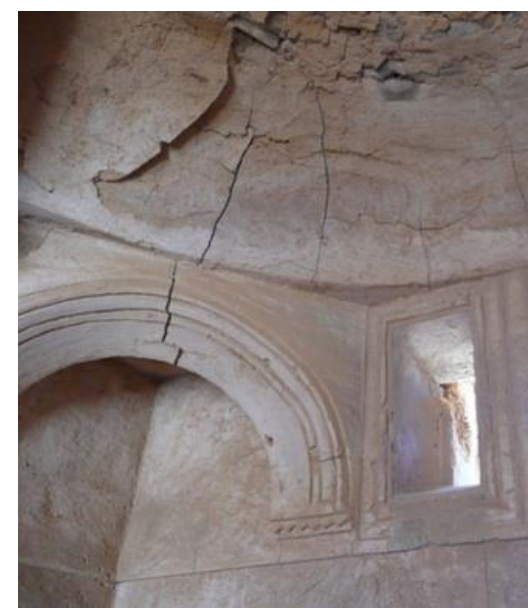

Figure 88: Roman Mesopotamian Tradition

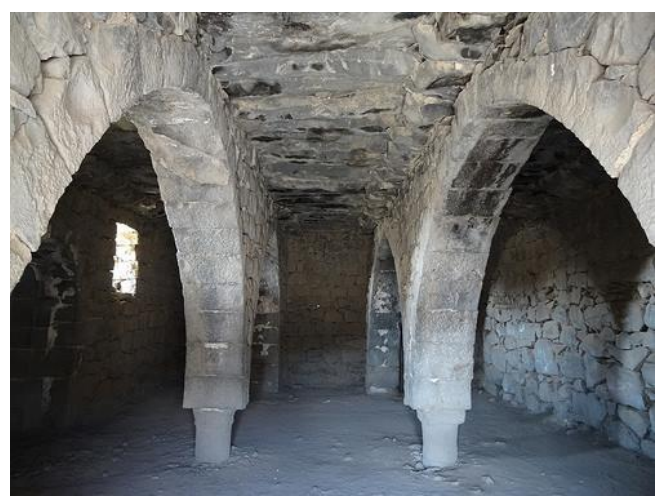

Figure 90: Roman Tradition 


\subsubsection{Umayyad Emirates Domes in Islamic Iberia: 711-899 AD}

Islamic Iberia is divided into different periods: starting from the conquest by Islam, Emirate, Caliphate, Taifa Kingdoms, Moravids, Mohads and Nazari Kingdoms. The Umayyad conquest of Islamic Iberia in $711 \mathrm{AD}$ was the initial expansion of the Umayyad Caliphate over Hispania ${ }^{14}$. During 661 and 750 AD, The Umayyad Caliphates in Damascus went through three civil wars. The Last one resulted in demolishing the Umayyad Caliphate by Abbasids in 750 AD. A branch of the Royal Umayyad family, Abdul Al Rahmanl, escaped across North Africa to Islamic Iberia ${ }^{15}$ and became the independent Emir of Cordoba in 756 AD till 788 AD. Abdul Rahman I, made Cordoba the capital of Al Andalus ${ }^{i}$ and laid out a Mosque to his providence by converting the Basilica of San Vicente Martyr ${ }^{16}$ to The Great Mosque of Cordoba [1] [2]. In 784-786AD, an expansion to the mosque occurred. The architects had obtained many columns from Ancient Roman Temples and rebuilt the Mosque with different columns of different Temples. It was more efficient to use the Spolia approach during the Islamic period which is by reusing columns from previous Roman complexes to decrease the time needed in building a new structure [3] [4]. Umayyad had used the Spolia approach when building the Dome of the Rock in 691 AD.

Reusing previous architectural elements in building reflects the power of the Dynasty by destroying the previous complexes. It also

[3] (Lapunzina, 2005)

[4] (Dodds, Jerrilynn Denise, Maria Rosa Menocal, and Abigail Krasner Balbale , 2008) save time and cost. This Building approach occurred in several Islamic monuments and complexes as it was applied in Dessert castles built during the Umayyad period in Syria, Jordan and Palestine dessert as

\footnotetext{
14 The Roman name for the Iberian Peninsula

${ }^{15}$ Al Andalus

16 Basílica de San Vicente
} 
well as in North Africa in The Great Mosque of Kairouan and Zaytuna Mosque in Tunis. This approach was the initial practice that Islamic Architecture had adopted in their architectural building methods [1]. In VI century, Cordoba was an important place in the Provincial Hispanic of the Byzantine Empire in 552-572 AD. Later, the Visigoths had exposed their art to the province. The art produced during the Visigoth era was the result of local Roman traditions combined with Byzantine influences [2]. In the VII century, Iberia was ruled by the Visigoths, and the oldest Church was built by the Visigoths within the year $661 \mathrm{AD}$. It is built of dry-stacked ashlar stone, and is a simple basilica of three aisles which is different than the Islamic hypostyle layout. The prayer hall or sanctuary is supported by rows of columns and there is an open courtyard, which a typical characteristic of a simple hypostyle Arab Plan. The Great Mosque of Cordoba comprised a large hypostyle ${ }^{17}$ Prayer Hall. The hypostyle comes from the Ancient Greek and means "Under Columns" with a combination of columns and arches [3]. This design was adopted by Arabs in their Mosque building designs.

Shadieh Mirmobiny, a Professor in Art History at Sierra College at Rocklin in CA cited:

'Historians believe that this site was a temple to the Roman God, Janus. The temple was converted into a Church by invading Visigoths who seized Cordoba in 572AD. Next, the Church was converted into a Mosque and then completely rebuilt by the descendants of the exiled Umayyads - the first Islamic dynasty who had originally ruled from their capital Damascus from 661 until 750AD. ' [4]
[1] (Achour, 1991)

[2] (Creswell,

K.A.C.1989)

[3] (Dodds, 1992)

[4] (Mirmobiny, XX)

${ }^{17}$ Filled with colums 
According to history, the Great Mosque of Cordoba had been

initiated under the reign of the first Emir Umayyad, Abdul Rahman

I, between 780 and 785 AD on the grounds of Basilica of San

Vicente Martyr, which resulted into changing the direction of its

axis [ Figure 100] [2 [3].

The Mosque went through an additional expansion during Abdulrahman // in 848 AD and later, in 961-966 AD during Al Hakam II and it was the most important expansion to the Mosque as the Cross Ribbed Vaults were added in Al Maqsura area of the Mosque [Figure 99].

Andrew Petersen in his book: 'Islamic Architecture Dictionary' mentioned:

'The earlier, ninth-century Al Mihrab roofed by a large dome supported on ribs resting on cusped arches. Next to this Mihrab is the Maqsura or royal enclosure which is equally grand with carved stucco decoration and interlaced cusped horseshoe arches. The tenth-century Mihrab consists of an octagonal chamber set into the wall with a massive ribbed dome supported on flying arches. The interior of the dome is decorated with polychrome gold and glass mosaics which may $b$ a gift of the Byzantine emperor. This mihrab suggests the change in status of the Umayyad rulers from amirs to caliphs'. (Petersen, 1996). [4]
[2] (Ettinghausen, and Oleg, 1987)

[3] [5] (Khoury, 1996)
[4](Petersen, 1996)

P. 56

This addition is considered the evolution period in construction at that time. The equally incredible vault built in the $X$ century is one of the sparkling art pieces in the Islamic Iberia history [5]. 
Shadieh Mirmobiny Assistant Professor in Art History at Sierra Community College mentioned in her academic article:

'The Great Mosque of Cordoba is a prime example of the Muslim world's ability to brilliantly develop architectural styles based on pre-existing regional traditions. An extraordinary combination of the familiar and the innovative, a formal stylistic vocabulary that can be recognized as "Islamic" even today.' [1]

And added:

'This astonishing building technique anticipates later Gothic rib vaulting, though on a more modest scale.' [2].

Ruben Gomez a Spanish Scholar mentioned in his research paper: The civilization of Islam stated:

'Al Hakam II had asked the emperor of Constantinople to send him an artist able to perform the work with the necessary materials. The craftsman came and trained students soon match his teacher [3].'

The Dome centering Al Mihrab Space is intersected by two other Vaults

[3] (Gomez, xx) on the sides. The cross arches that create the vault link the hemispheric spaces [4]. Intersecting vaults is a method originated from Persian traditions that were practically famed in the Sassanid era. These vaults [4] (Cahen, 1995) feature arches that do not cross in the center, but they draw a polygon or a star which famed initially in Spain [5]. Cress-cross arches were technically an advanced Method in the tenth Century. There are three [5] (Gomez, XX) P. 118 Domes located in the Maqsura and a small vault in the Mihrab area, which is known as the Qibla wall as it indicates the Qibla ${ }^{18}$ direction. The Mihrab Central Domes was constructed during Abdul Rahman I but the ribbed cross vaults were added to Al Maqsura during Al Hakam II.

\footnotetext{
${ }^{18}$ The direction of Mecca
} 
Al Hakam II the vaults addition were considered the peak of the tenth century architectural art during the Umayyad Caliph Period. The golden section appears repeatedly in some part of the Great Mosque measurements. It is found in the overall proportion of the plan and in the dimensioning of the prayer space, the court and the minaret. The existence of the golden section in some parts of Kairouan mosque indicates that the elements designed and generated with this principle may have been realised at the same period. This suggests and opens the possibility for further inquiry into the dating of the transformations that took place in this mosque. Authors Kenza Boussora and Said Mazouz examine earlier archaeological theories about the mosque and demonstrate the geometric constructions for the golden section, and apply these constructions to the plan of the mosque to test their hypothesis [1].
[1] (Kenza Boussora and Said Mazouz, XX)

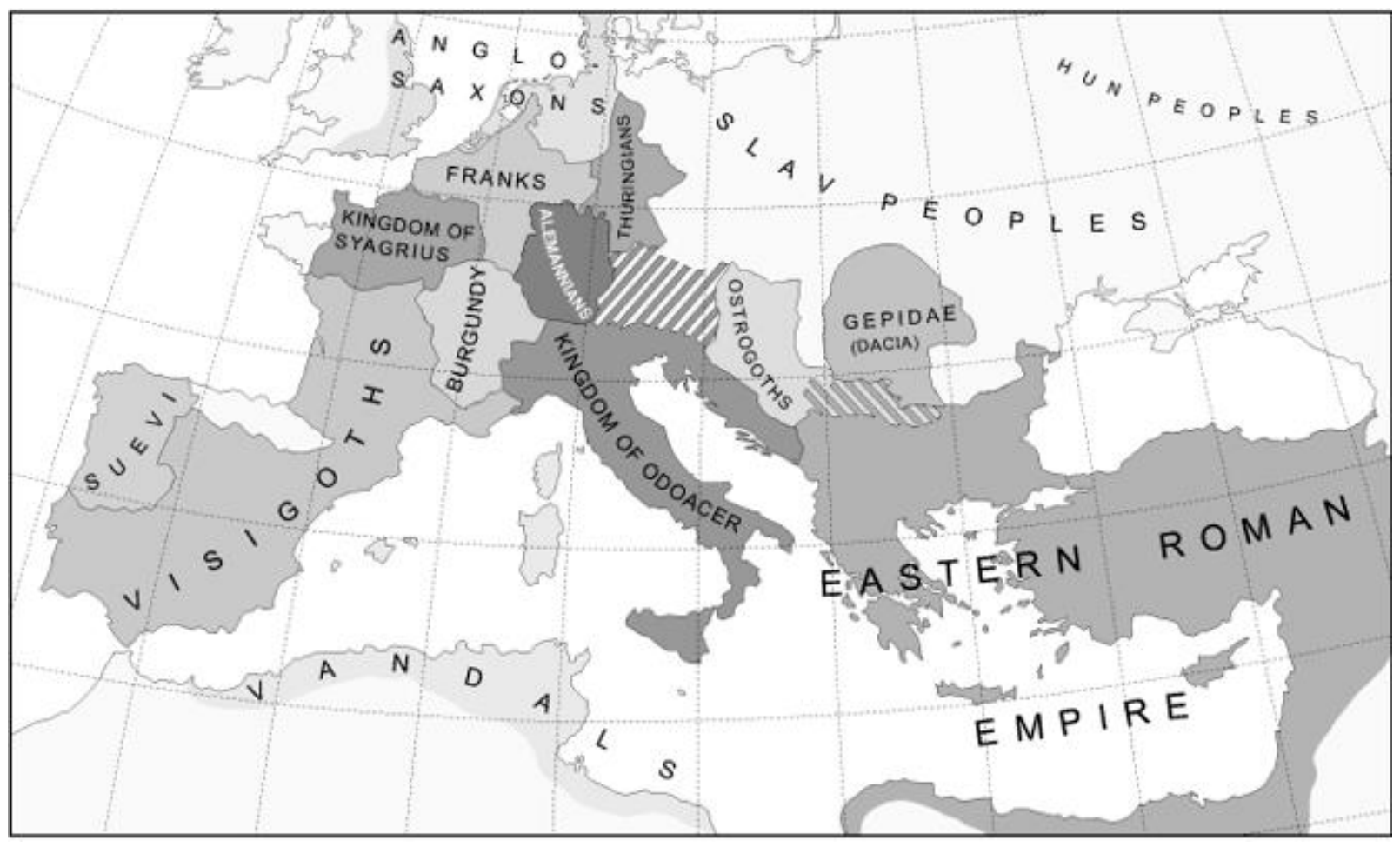

Figure 91: Visigoths Location 


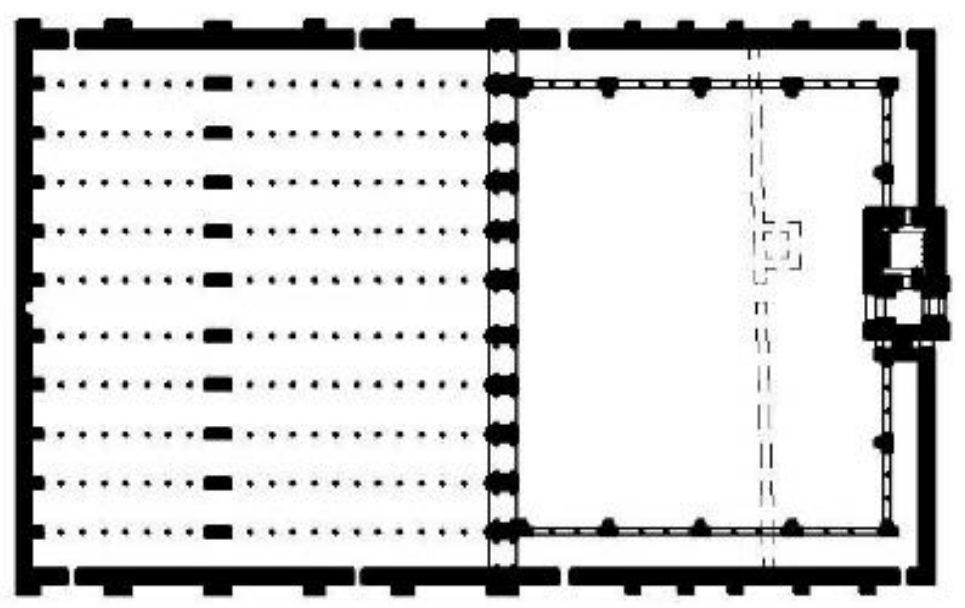

Figure 92: Great Mosque of Cordoba, in 572AD

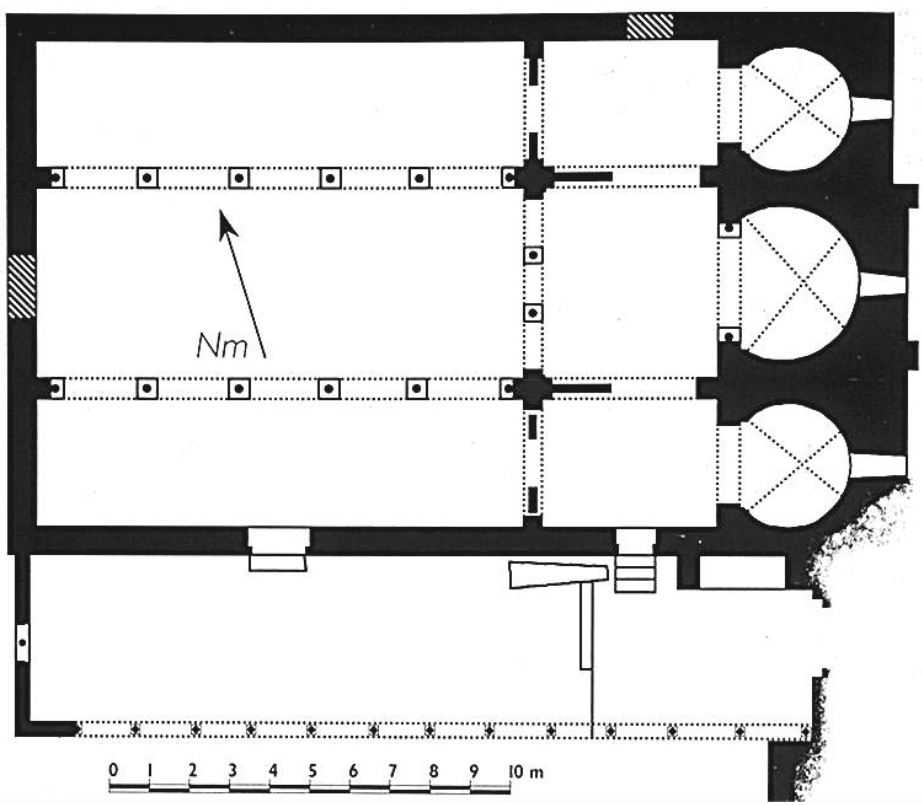

Figure 93: Basilica of San Vicente Martyr Plan

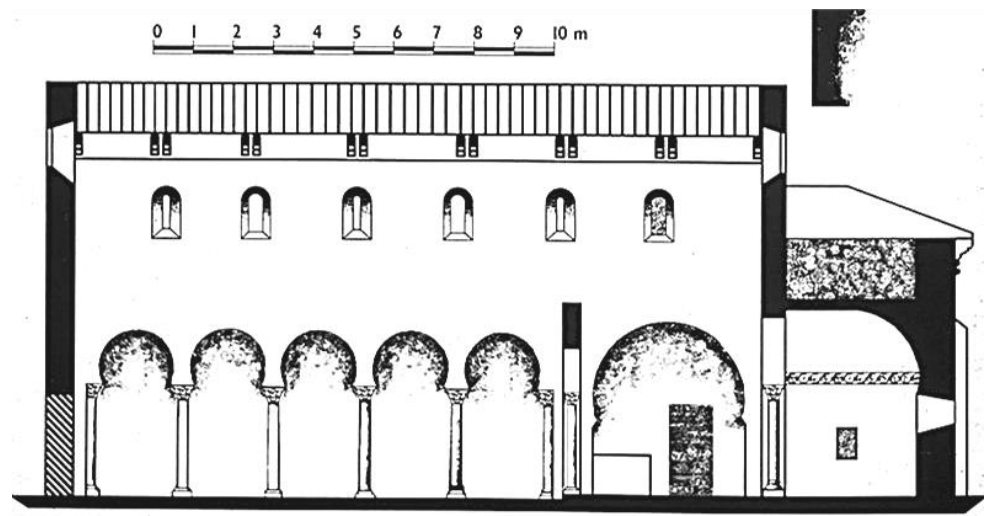

Figure 94: Basilica of San Vicente Martyr Section

Source: After Huerta 


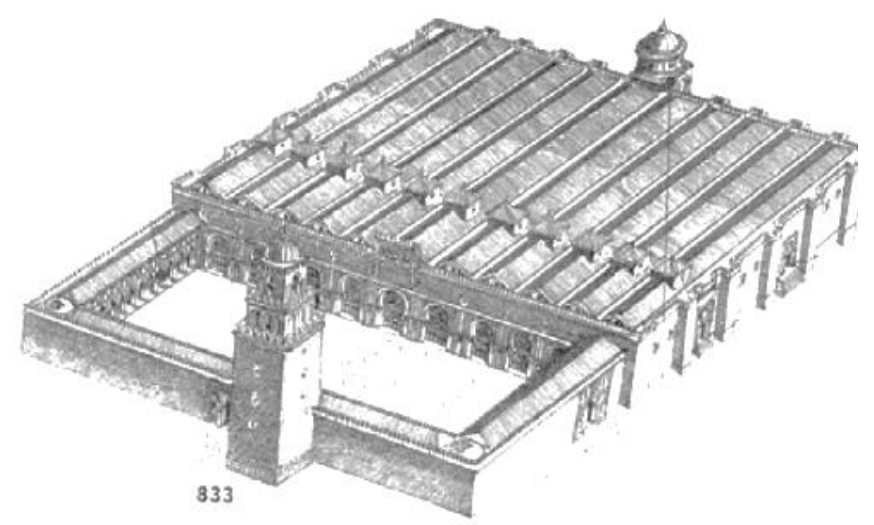

Figure 95: Cordoba Mosque in IX century, 833AD

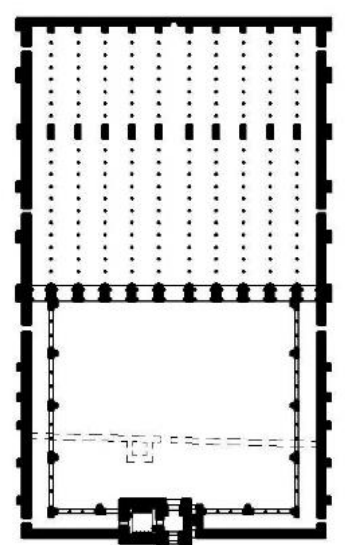

Figure 96: Cordoba Mosque Plan , 833AD

Source: After: Carlos Mas Arrondo

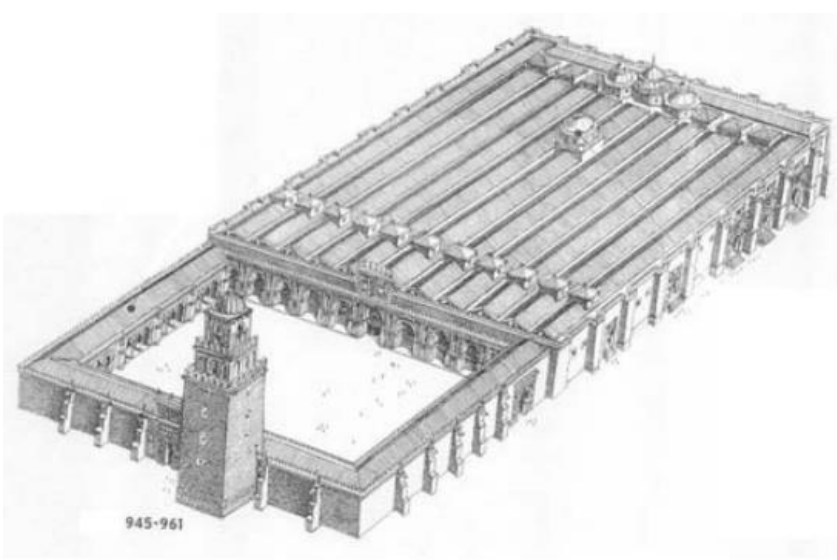

Figure 97: Cordoba Mosque in X century, 945- 961AD

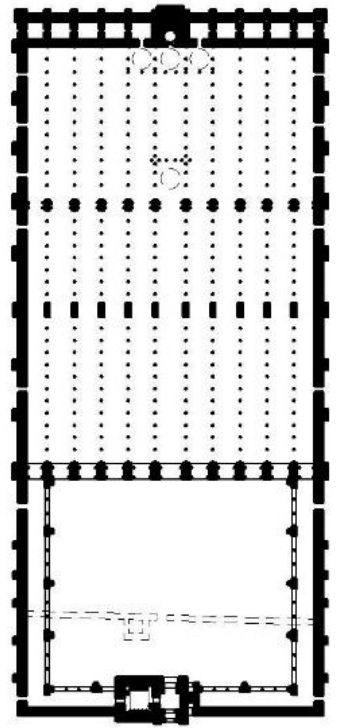

Figure 98: Cordoba Mosque Plan, 945- 961AD 


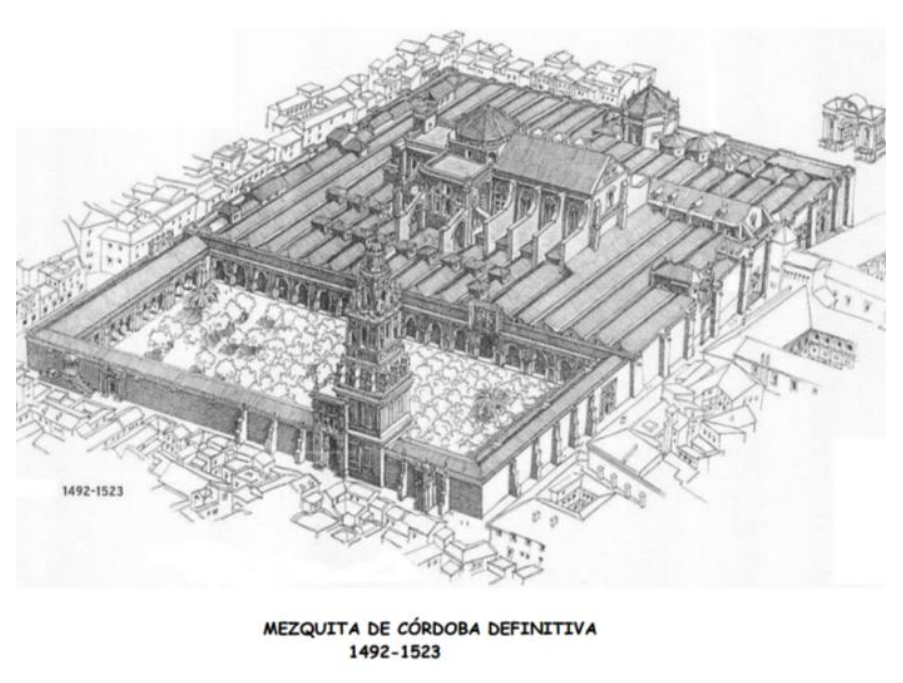

Figure 92: Current Vasilica, Cordoba

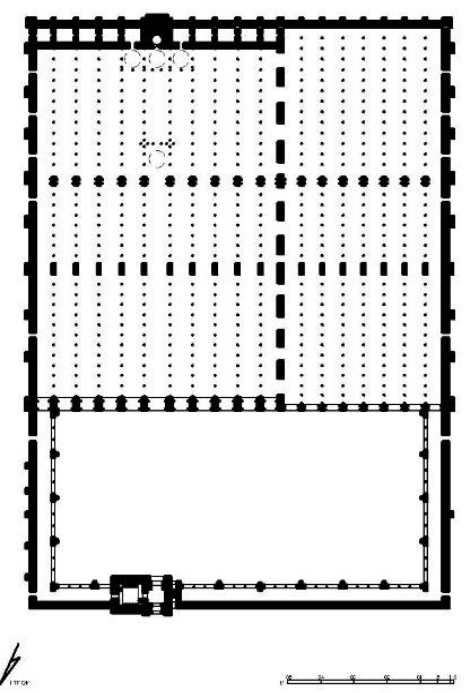

Figure 99: Cordoba Mosque Plan, 14921523AD

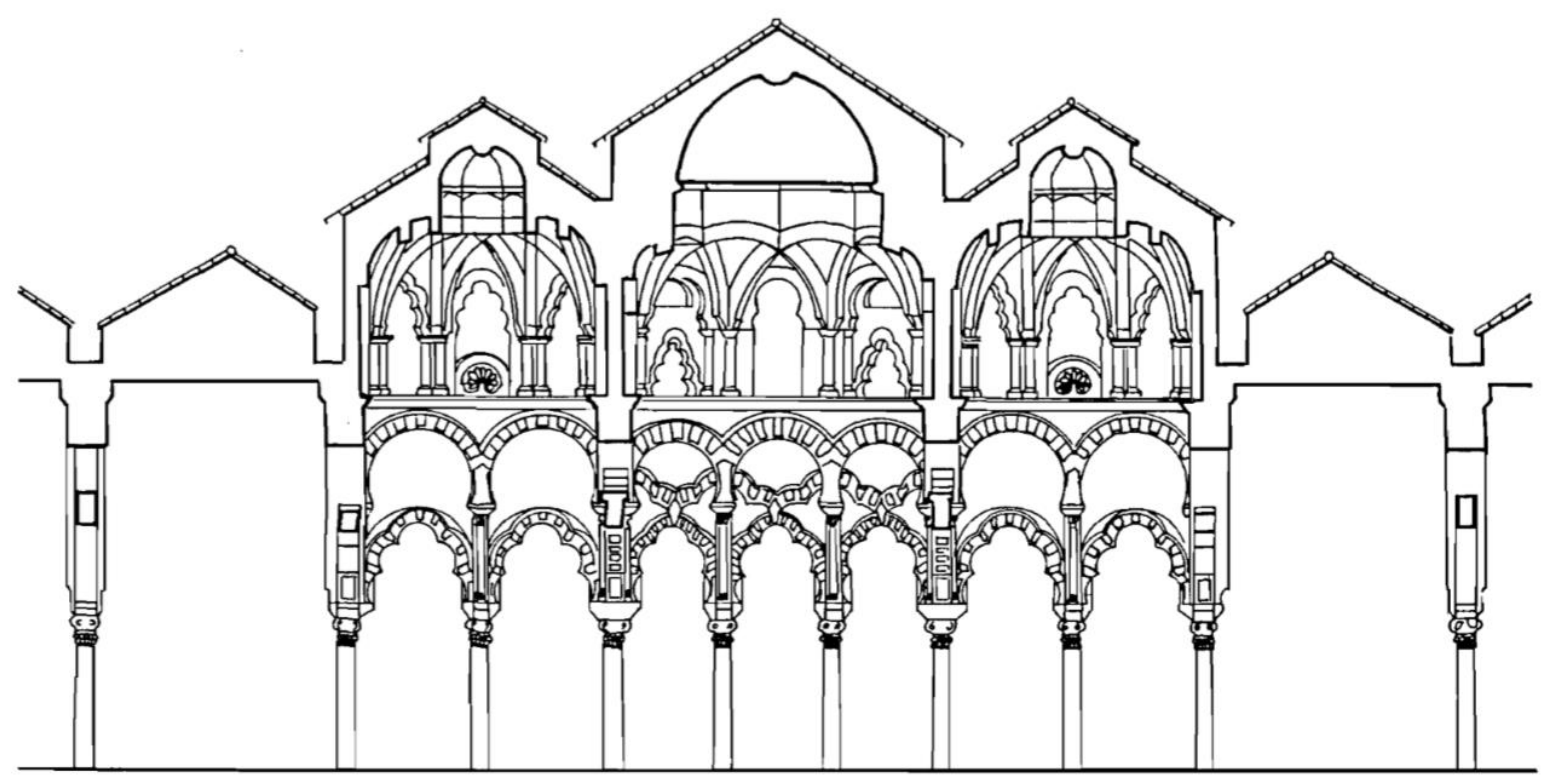

Figure 100: Section trough The Great Mosque of Cordoba Source: after Barucartd 
In 670 AD, Uqba bin Nafi' had conquered North Africa and settled in Kairouan City and constructed a Friday Mosque Known as the Great Mosque of Kairouan, which was an example of an early Hypostyle Mosque $^{19}$.

Dr. Colette Apelian, a professor in Berkely City Collage had mentioned in his academic article named as The Great Mosque of Kairouan:

'The aesthetics signified the Great Mosque and Kairouan, and, thus, its patrons, were just as important as the religious structures, cities, and rulers of other empires in this region, and that [1] (Apelian, 2014) Kairouan was part of the burgeoning Islamic empire.' [1] (Apelian, 2014).

The Great Mosque of Kairouan, which also famed as Jami' Uqba Ibn Nafi' was rebuilt in the ninth century by Ziyadat Allah, the third ruler of the Aghlabid dynasty, a branch of the Abbasid Empire. A large rectangular stone mosque with a hypostyle hall and a large inner Sahn ${ }^{20}$. The hypostyle plan was used widely in Islamic lands prior to the introduction of other Islamic plans. The Great mosque of Kairouan Mosque is the hypostyle plan example with the location of the two domes on one axis from the entrance to al [2] (Uthman, 2000) Mihrab ${ }^{21}[2]$.

\footnotetext{
19 supported by columns

${ }^{20}$ courtyard

${ }^{21}$ The location of Mecca Direction
} 


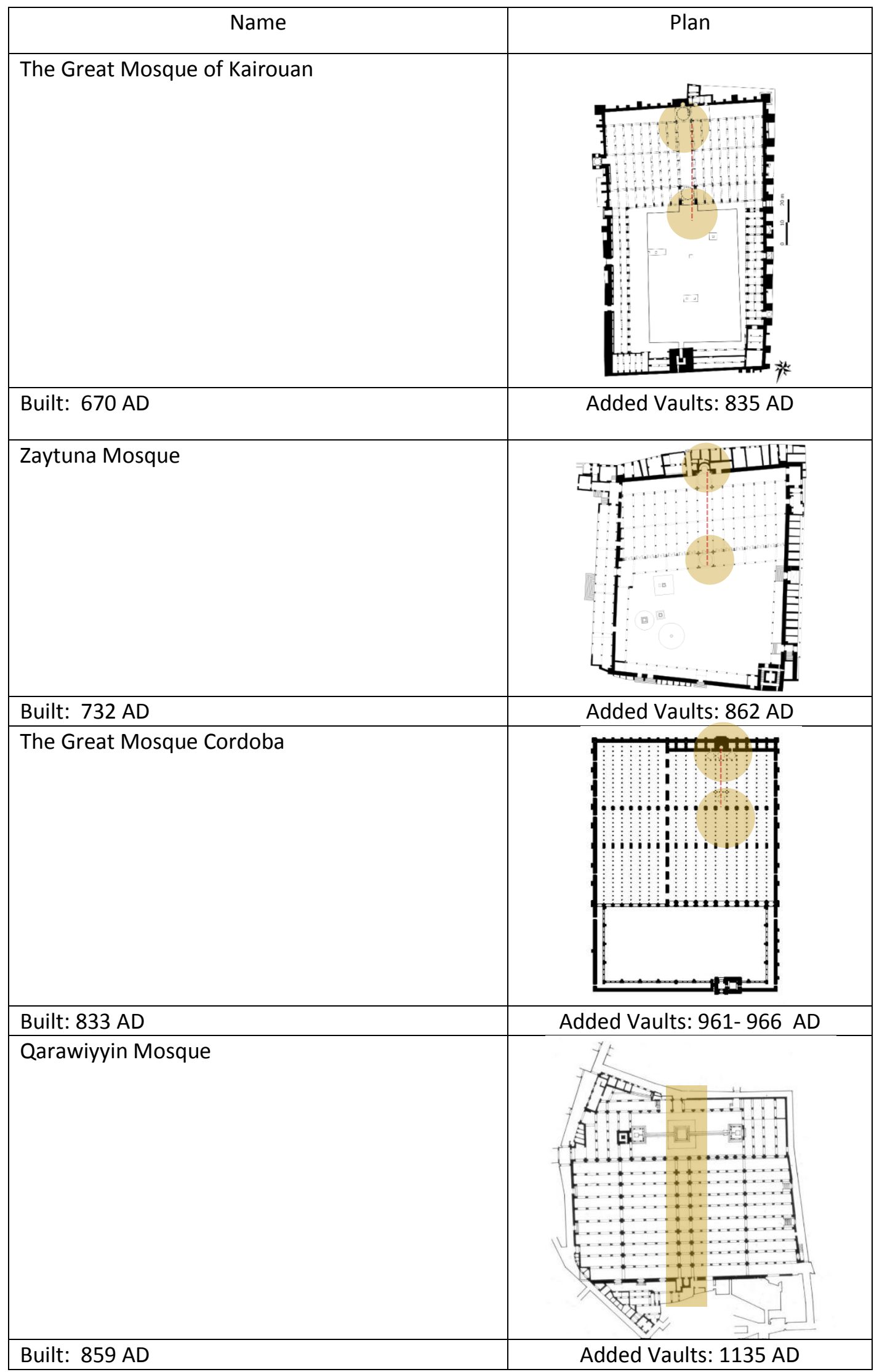

Table 3: North Africa and Spain Domes during VIII -X Centuries 


\subsubsection{Umayyad Caliphates Domes in Islamic Iberia: 912- 999 AD}

Soon after Abdul Rahman III the son of Al Hakam II, he added the Mihrab vault in the Great Mosque of Almeria during 912-961 AD [1]. Almeria Great Mosque which was converted later to San Juan Church, contains a Mihrab of lobbed dome structure [Figure 103] [2]. The Mihrab of the mosque is rebuilt in Al Mohad period.

During the tenth century, a small mosque of Bab Al Mardum in Toledo was built, which had been converted later to Cristo de la Luz Church. The Islamic side of the Mosque is a square plan includes three naves covered with nine domes of varied criss-cross arches copying the developed construction method in the Great Mosque of Cordoba. Toledo was the capital of the Spanish Visigothic kingdom from $554 A D$ until the Muslim conquest in $711 \mathrm{AD}$ and made it part of Islamic Iberia [3]. The mosque of Bab Al Mardum was built around 999 AD. The square plan of The Mosque composed of nine bays copying Afghanistan Method called: No Gumbad Plan [4]. Instead each of these bays is covered with a cross vault with distinctive vault design. The central vault is higher than the others performing a cupola for the whole structure [5]. The cupola is a small structure on top of a building, most often dome, used to provide light and air inside the building. The Ribbed Vaults typically do not cross the center a star created in the center formed by the crossing arches intersections. This approach started initially in Islamic Iberia [6] [7] [8].
[1] The most famous member of this dynasty was Abdul Rahman III who reigned for fifty years between 912 and 961. (Petersen, 1996) P. 263

[3] The Arab conquest was carried out by Musa the commander of North Africa with Tariq. Within a year Toledo, the Visigothic capital, had been captured. (Petersen, 1996) P. 263

[4] (Marcais, 1954) P.151-152.

[5] (Turismo, 2014)

[6] (Moreno, 1951)

[7] (Balbás, 1935) P.398-410.

[8] (Fuentes and Huerta, 2010) 


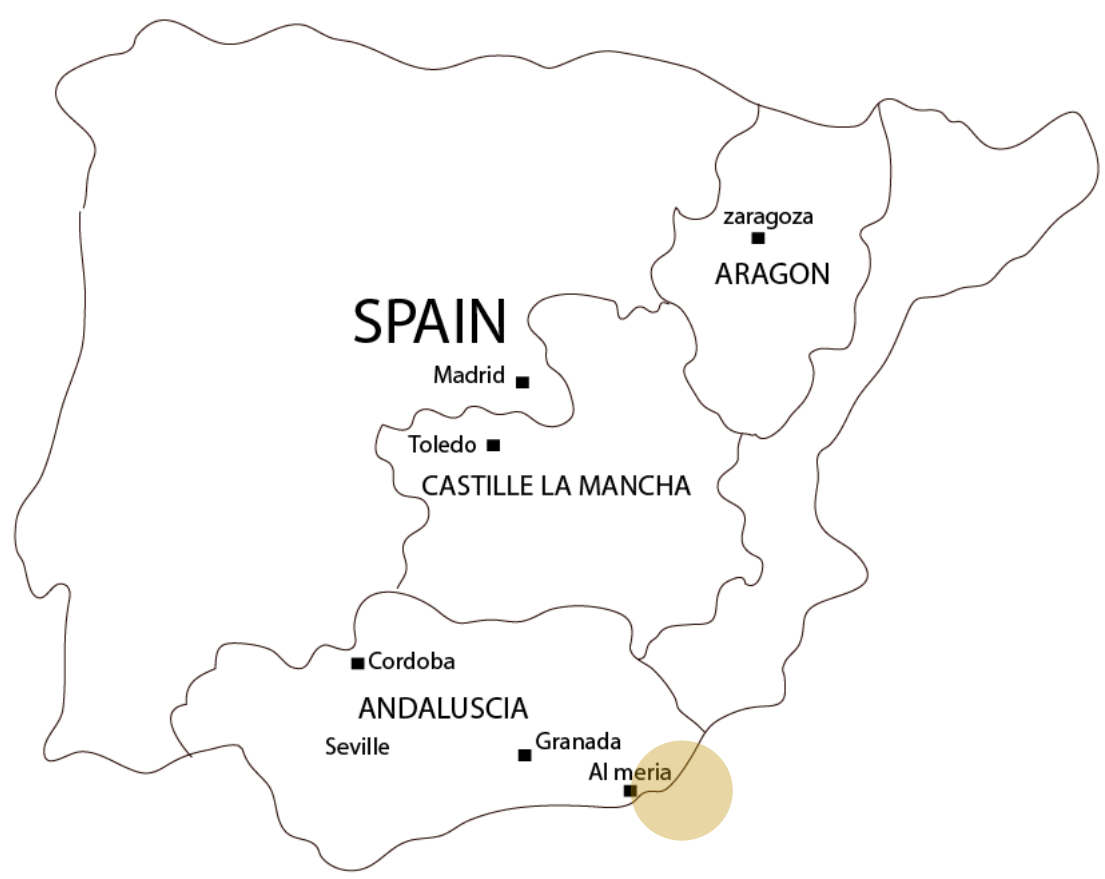

Figure 101: Great Mosque of Almeria Location, Built during 912-961 AD

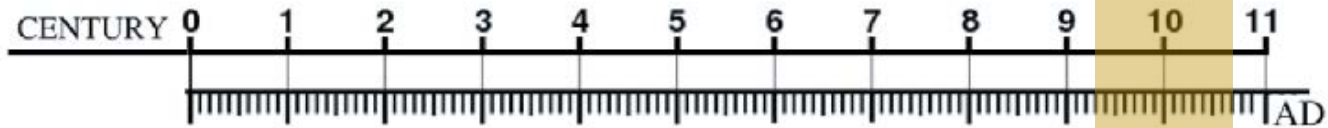

912-961
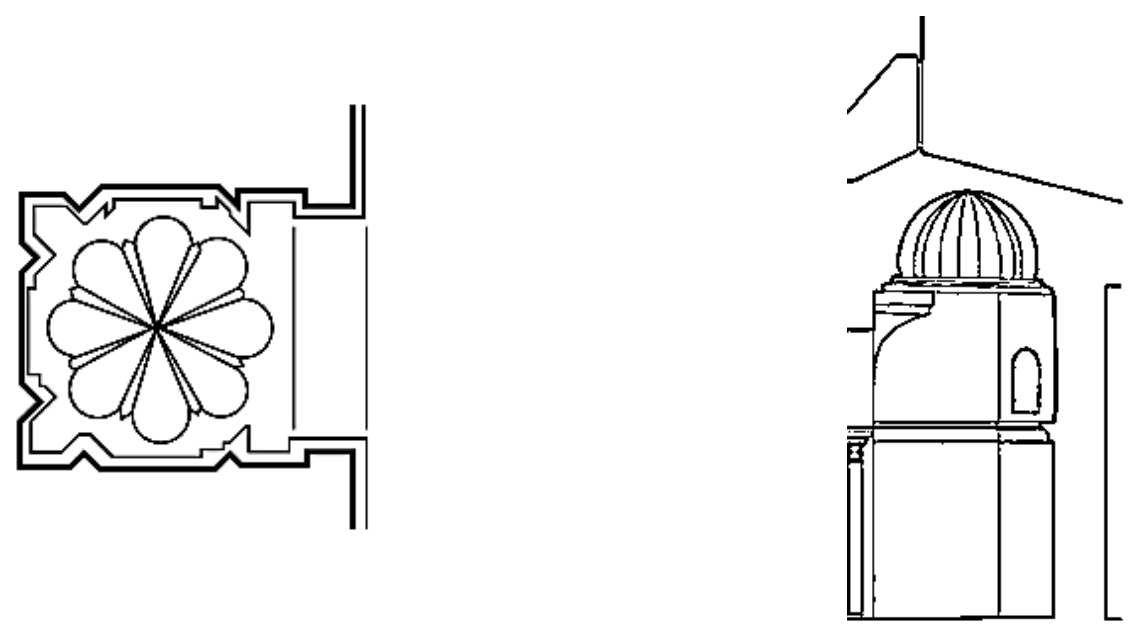

Figure 102: The Great Mosque of Almeria Vault Plan

Figure 103: Mihrab Almeria Section Illustrations by the Author 


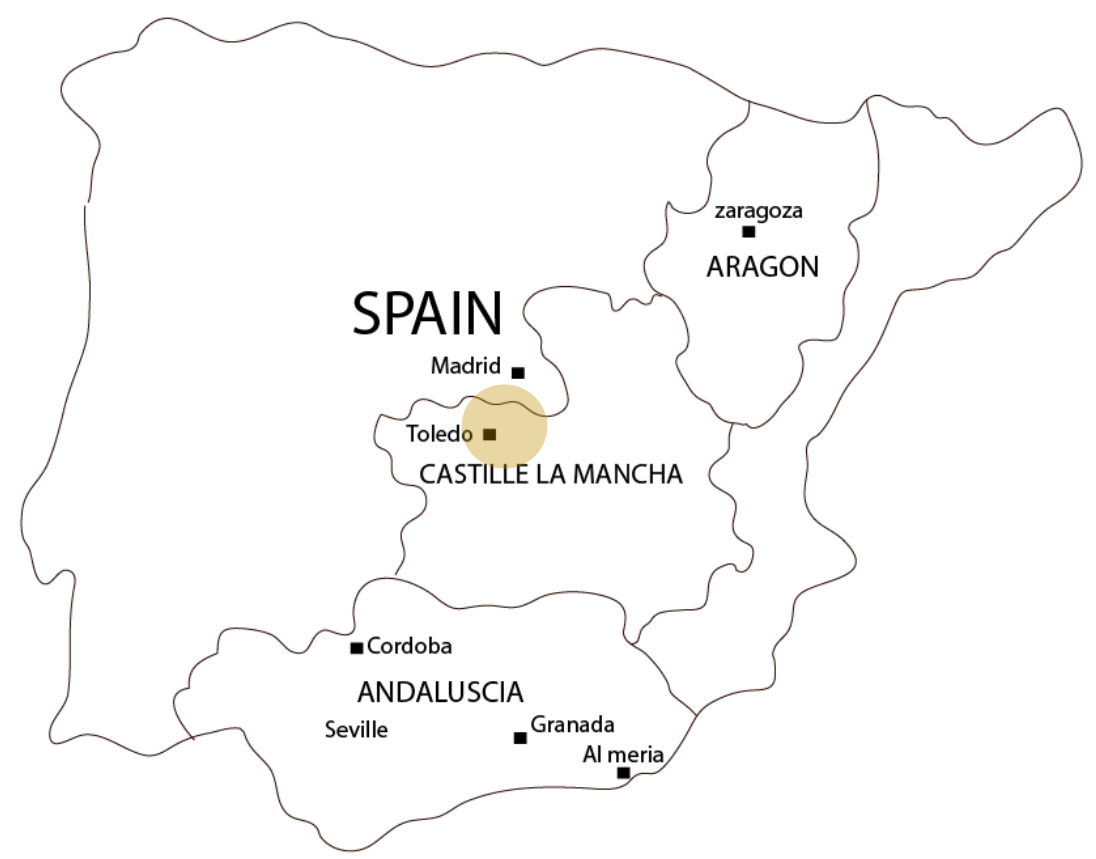

Figure 104: Bab Al Mardum Location, Spain

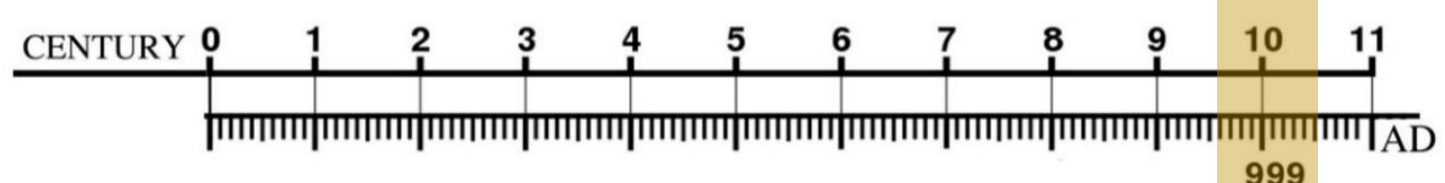

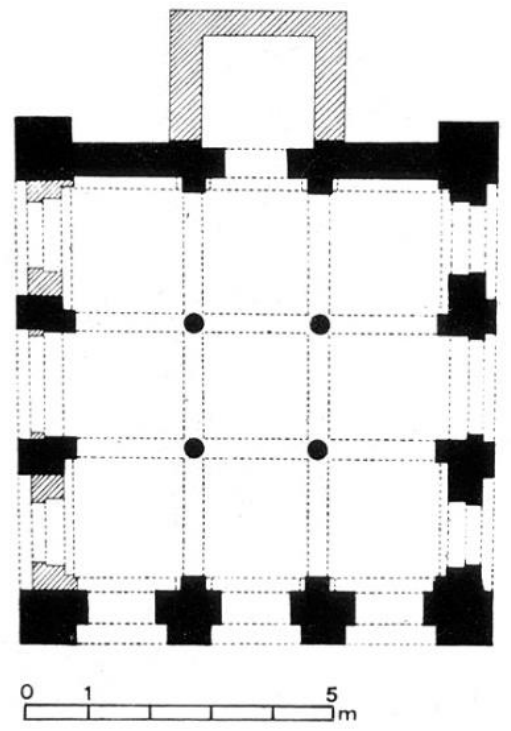

Figure 105: Bab Al Mardum Plan Source: After Archnet

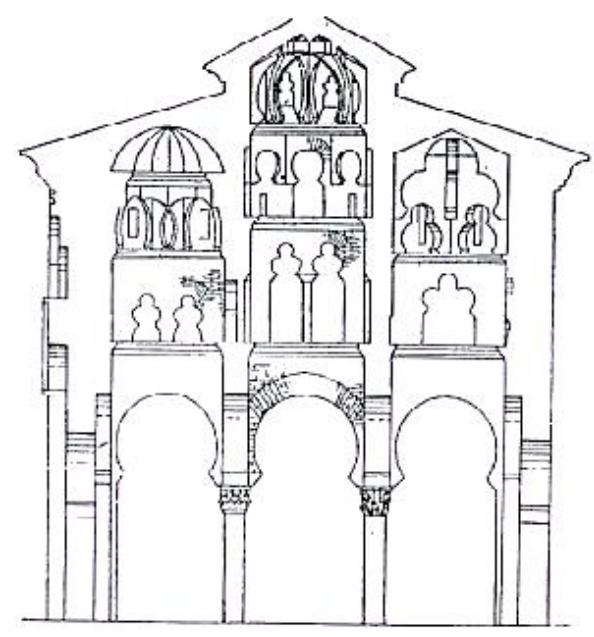

Figure 106: Section of Cristo de la Luz Source: After editorial DCA 


\subsection{Islamic Iberia Introduction: 1031 AD}

In the history of the Iberian Peninsula, after the final collapse of the Umayyad Caliphate of Cordoba in 1031 AD an independent Muslim Taifa Emirs started ruling Al Andalus, famed as Moorish Iberia which created kingdoms [1] [2].

\subsubsection{Taifa Kingdom: 1031 AD}

The fall of Umayyad Caliphates of Cordoba in 1031 AD, resulted into developing thirty three independent Taifa famed as: Muluk Al Tawaif. The strongest and largest Taifa in the initial period were Taifa of Zaragoza, Taifa of Toledo, Taifa of Badajoz and the Taifa of Seville which rose in the eleventh century. The only Taifa which conquered most of the weak neighbours was Taifa of Seville. Hansh ibn Abdallah Al San'ani, built the main mosque of Zaragoza famed as: The White Mosque. The Mosque consist of cross arched dome located in The Maqsura area [Figure 107] [Figure 109] [3]. This mosque was built after the fall of the Umayyad Caliphates in Cordoba [Figure 108]. At the same period, Hammadid Berber dynasty arose and ruled the Taifa Kingdom of Malaga and Algeciras. The dynasty was named after Hammud, a descendant of Idris ibn Abdallah. The Hammudids were part of Shi'ite Berber branch of Chorfa ${ }^{22}$ origin. Thus their Berber heritage gave them the nominal support of the Berber emirs and for being part of the Chorfa heritage, which made the Caliphal claim acceptable to many Arab and Andalusian groups. The last Hammudid Caliph was dethroned by the Zirids of Granada [4] [5] $[6]$.
[1]The term Moors
refers to the

Muslim inhabitants of the Maghreb, North

Africa and the Iberian Peninsula, Sicily and Malta during

the Middle Ages, who initially were of Berber and Arab peoples of North African descent. Medieval and early modern Europeans vari ously applied the name to Arabs, Berber North Africans and Muslim Europeans.

[2] (Fletcher, 2006)

[3] (William Montgomery Watt and Pierre Cachia , 2001)

[4] (Moreno, 1951)

[5] (Balbás, 1935)

P.398-410.

[6] (Scales, 1994)

\footnotetext{
22 Noble
} 
a. Zaragoza Mosque

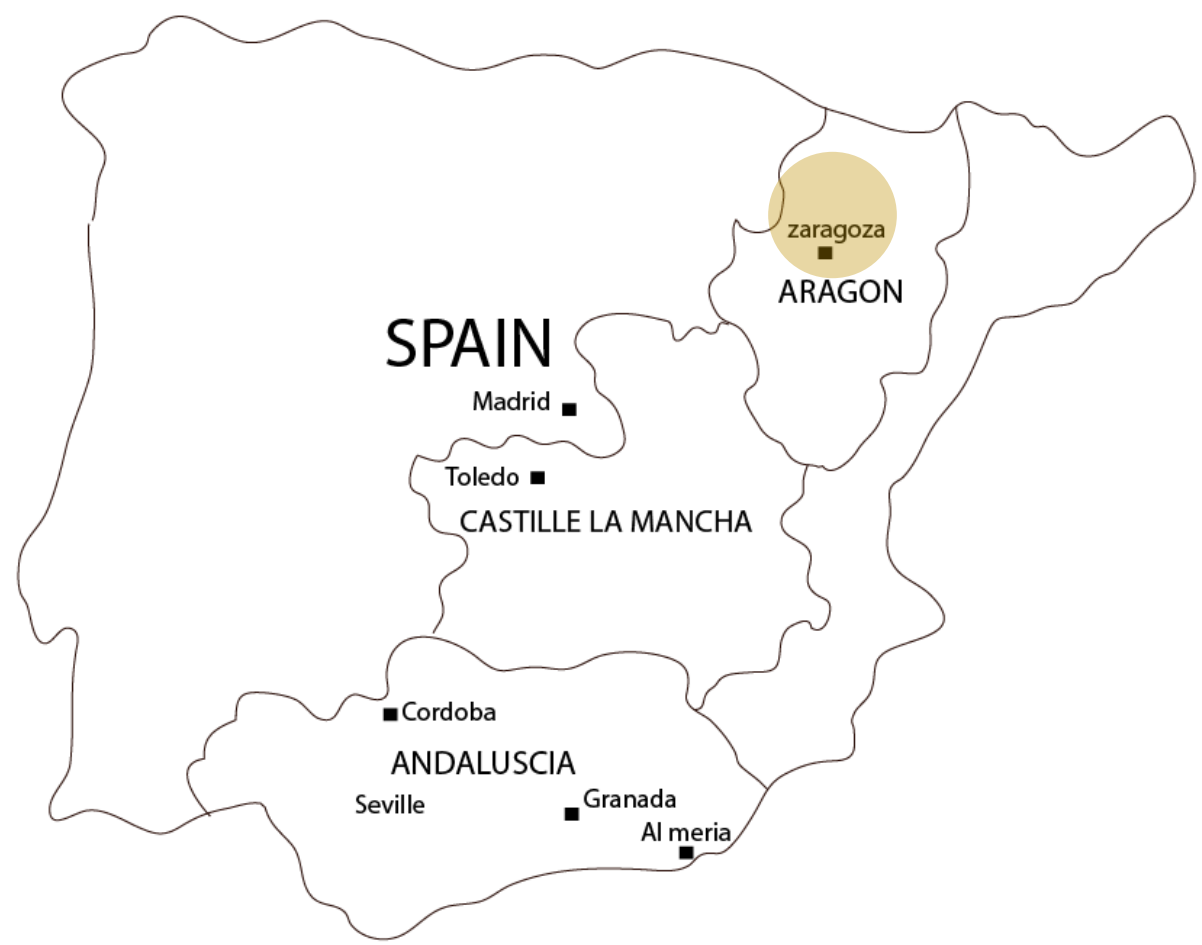

Figure 107: Zaragoza Mosque Location, Spain

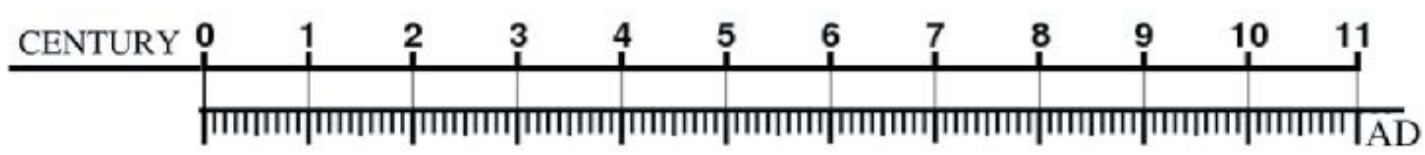

$1049-1082$
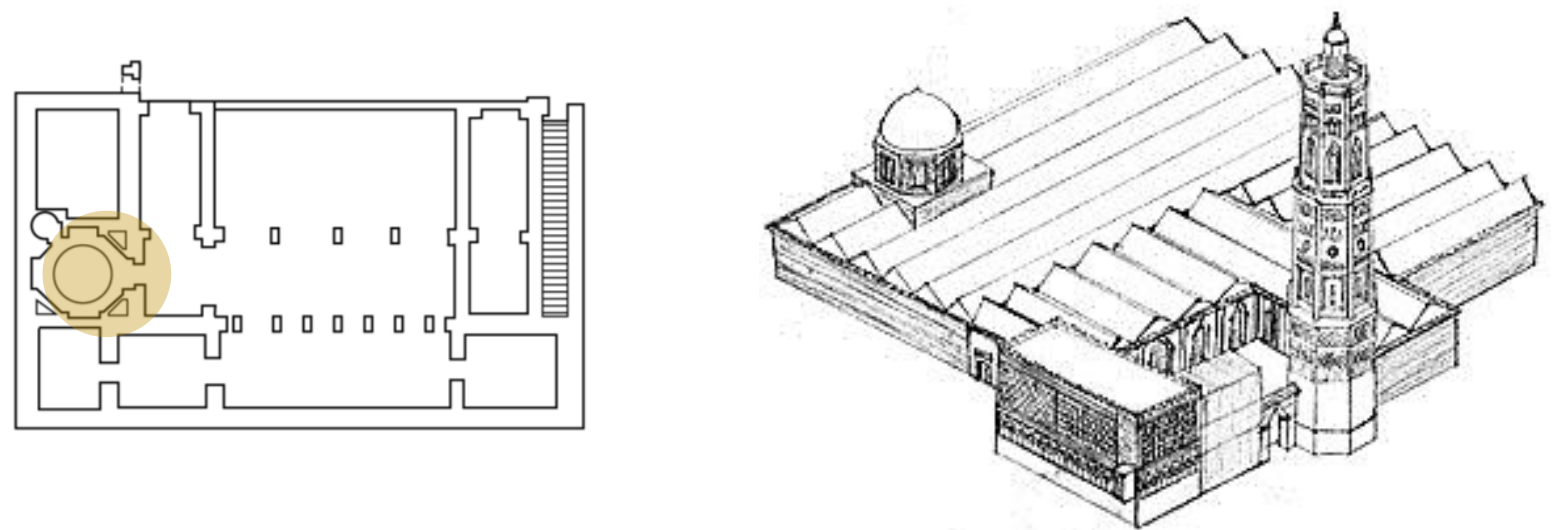

Figure 108: Aljaferia Palace Plan , 1065-1081 AD Source: Illustration by the Author
Figure 109: Aljaferia Palace and Mosque, 1065-1081 $A D$ 


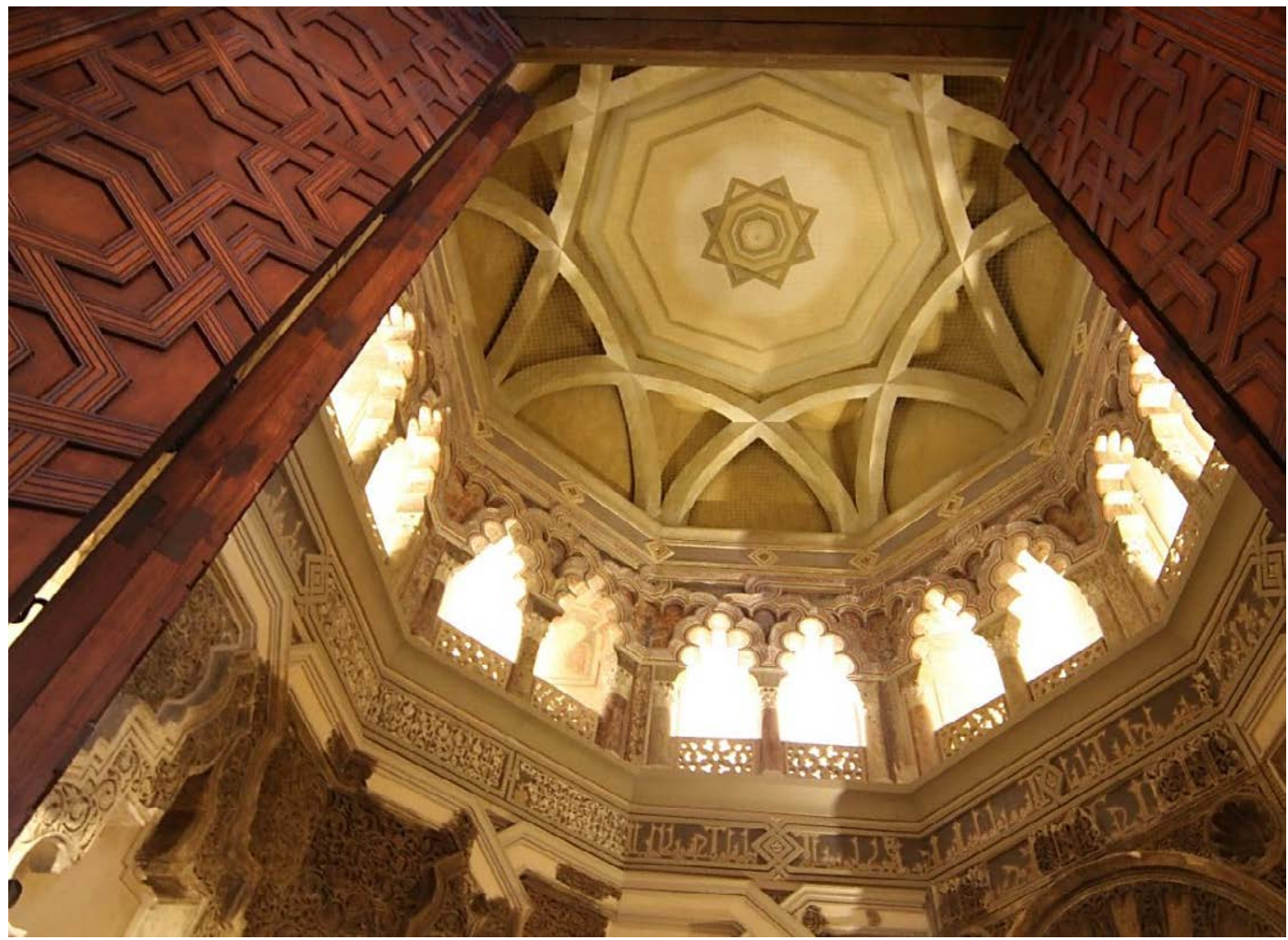

Figure 110: Maqsura Cross Arch Vault in Zaragoza Mosque

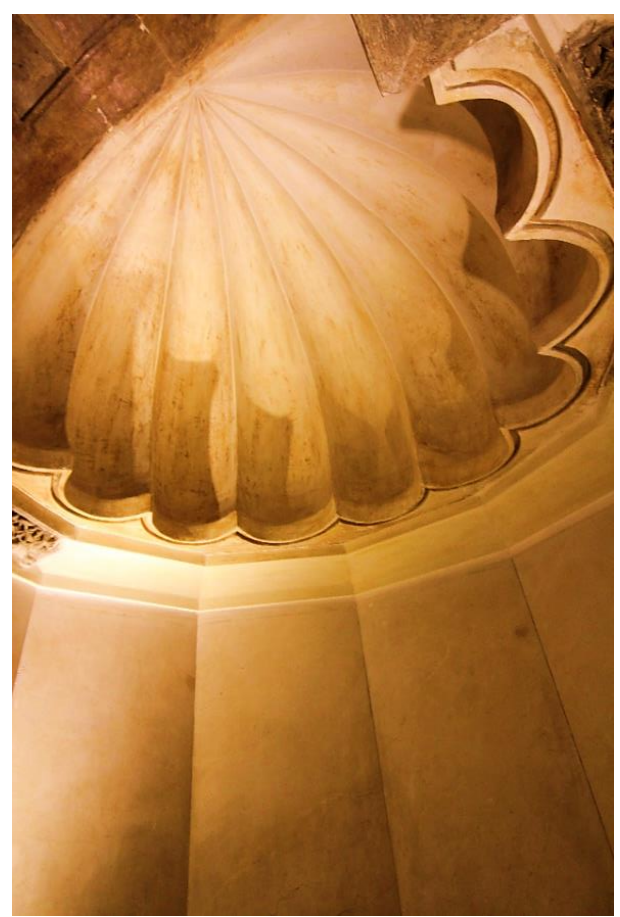

Figure 111: Close shot of Al Mihrab Dome

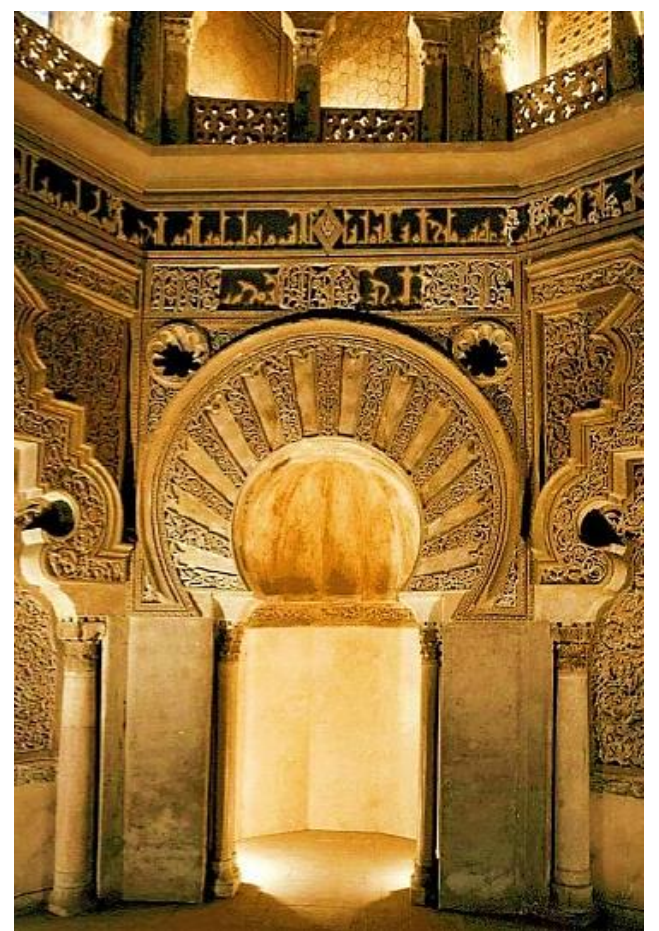

Figure 112: Al Mihrab, Zaragoza

Sourcee: Photos by the Author 


\subsubsection{Moravid Introduction: 1056- 1091 until 1146 AD}

Moravids in Islamic Iberia where expansion of local Moravids in North Africa. After the throw of the Taif Kingdom. The Berber dynasty of Morocco replaced the Taif Kingdom in Islamic Ibera by Emir Moravids who took over in 1056 AD. The Moravids had stretched a large dynasty over the western Maghreb and Al Andalus from their newly established capital in Marrakesh under Abdallah ibn Yassin in 1062 AD. Which later, Al Andalus became a Province of Moravid, a Berber Muslim empire [1] [2]. During this period a huge area from Senegal to Spain were ruled by Moravids. Ahmad mentioned in book Al Murabitoun stating:

'Yosef ibn Ali benefited from the talents of the enemy engineers to build a bridge. These Sahrawi invaders impose Andalusian art masterpieces on Islamic Maghreb [3].' (Translated)

Three Mosques were built in North Africa during Moravids Period. The Great Mosque of Algiers in 1006 AD built in 1097AD. It is one of the few remaining examples of Moravid architecture and considered the oldest mosque after Uqba in Nafi' Mosque. Later, Nedroma Mosque was built in 1145 AD. The Moravids evolution in Architecture started in 1082 AD when building The Great Mosque of Tlemcen in 1082 AD, which is considered the most important Moravid contribution to the history of Architecture [ Figure 115]. An imitation of the Great Mosque of Cordoba built under sultan Yusuf ibn Tashfin, but substantially reconstructed and enlarged by his son Ali ibn Yusuf. An inscription dates the reconstruction was to $1136 \mathrm{AD}[4]$. The most astonishing feature of the mosque is the Maqsura area in front of the Mihrab, a magnificent perforated dome carried on sixteen brick ribs and four small squinches. Between the ribs there is an intricate stucco latticework of stylized
[1] (Tubba, 2008)

[2] Christians of the north-west were able to exploit divisions amongst the Muslims to conquer extensive territories. The capture of Toledo by Alfonso VI of Castile in 1085 showed the weakness of these principalities and encouraged the conquest of Moravids in 1090AD. (Petersen, 1996) P. 264

[3] (Ashor, xxx) . P.23

[4] (Petersen, 1996) P.284 
floral motifs whilst at the apex of the dome is a small Muqarnas cupola. The entire dome is covered by a tiled roof on the exterior [Figure 122].

\section{a. Tlemcen Mosque}

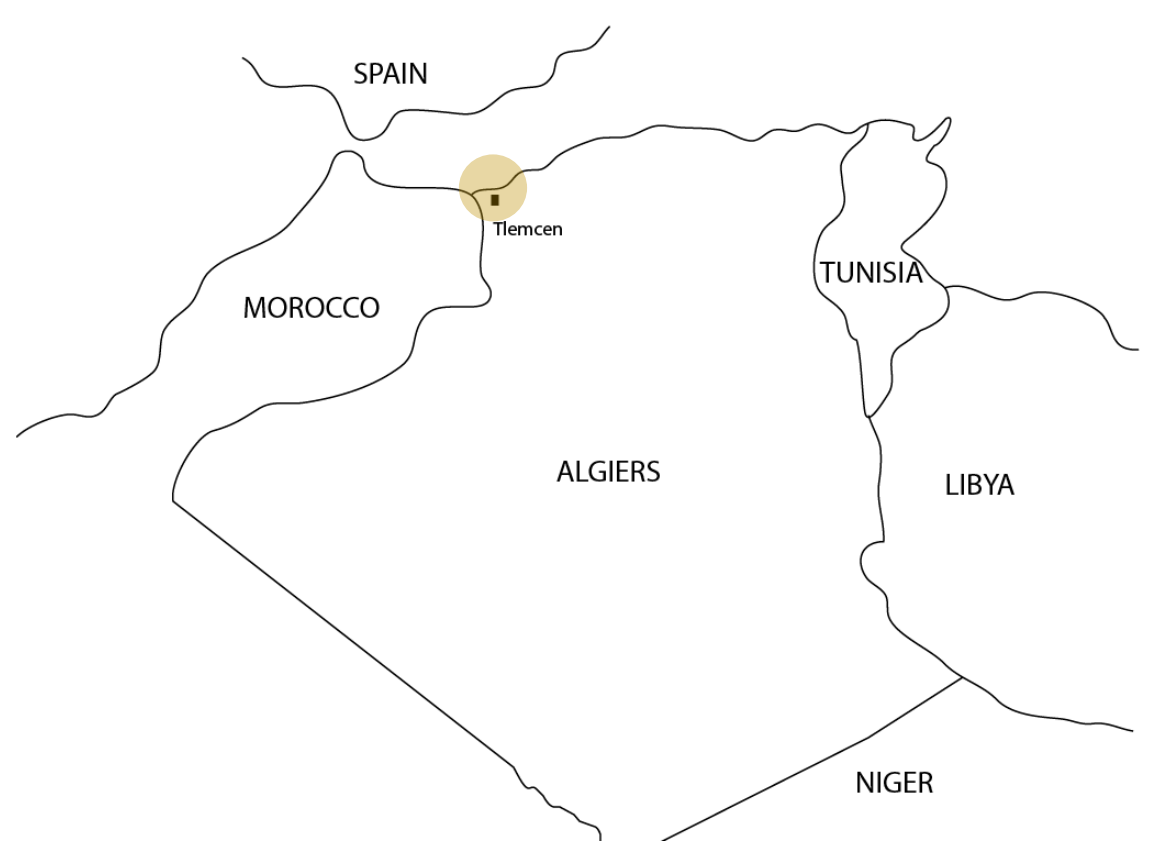

Figure 113: Tlemcen Mosque Location, Algeria
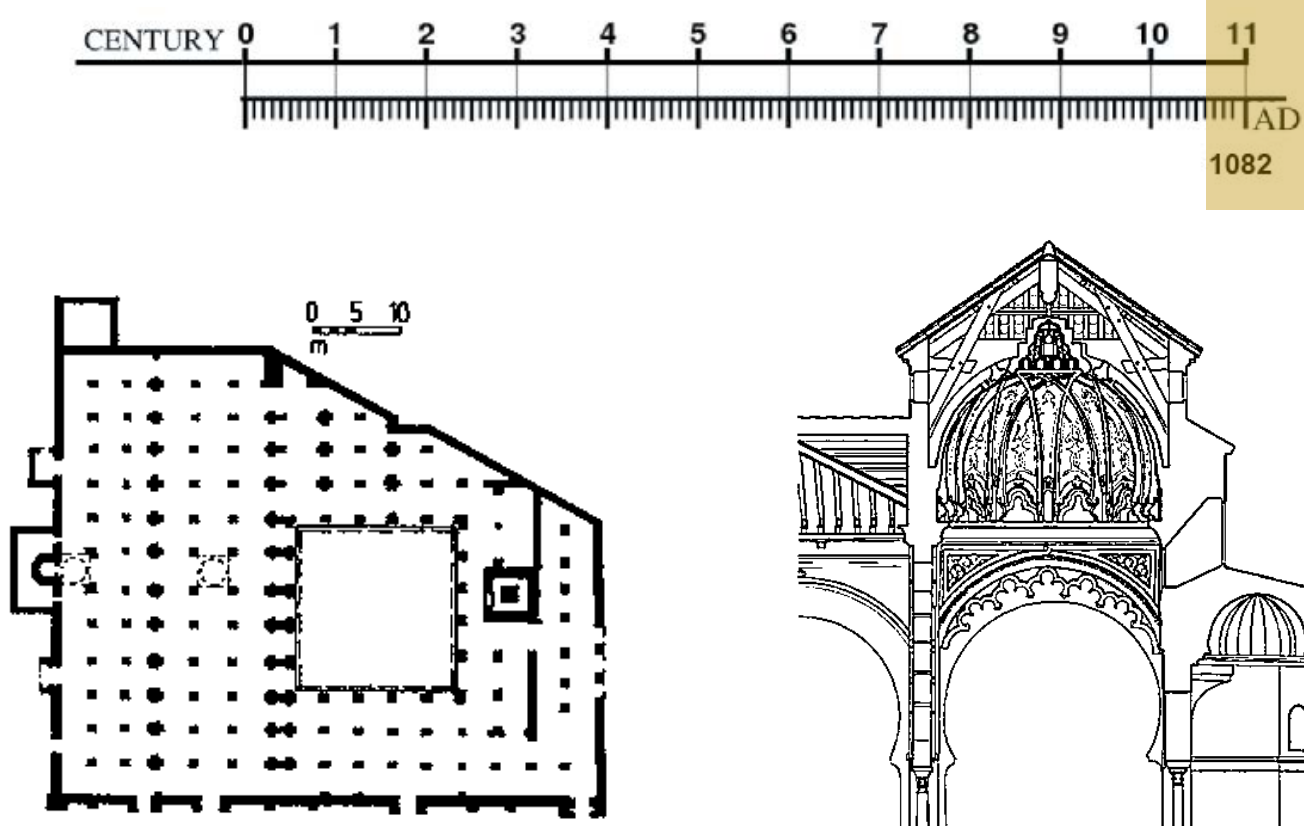

Figure 114: Tlemcen Mosque Plan, 1082AD,

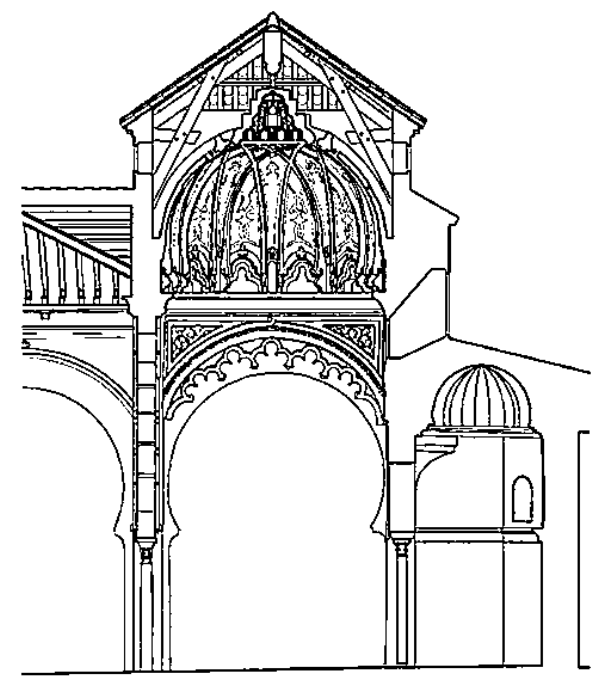

Figure 115: Tlemcen Mihrab Section

Source: Al-Qantara XXXVI 1, 2015, pp. 199-257 ISSN 0211-3589 doi: 10.3989/alqantara.2015.007 


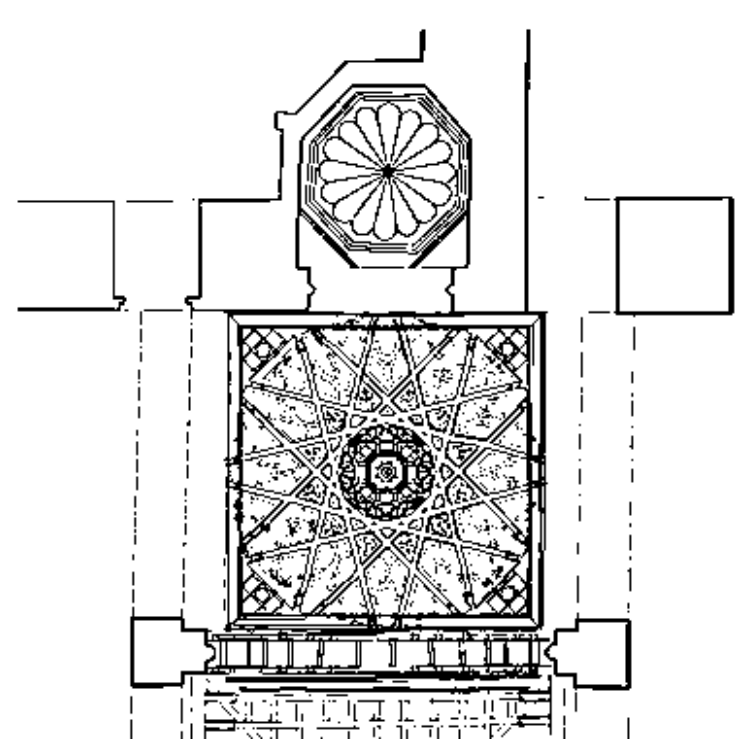

Figure 116: Mihrab Dome Plan, 1082AD

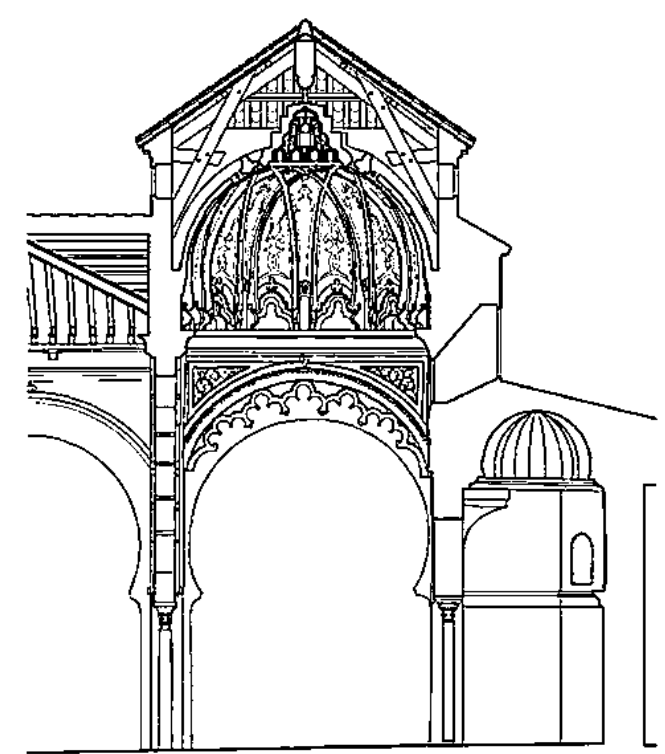

Figure 117: Mihrab Section, 1082AD

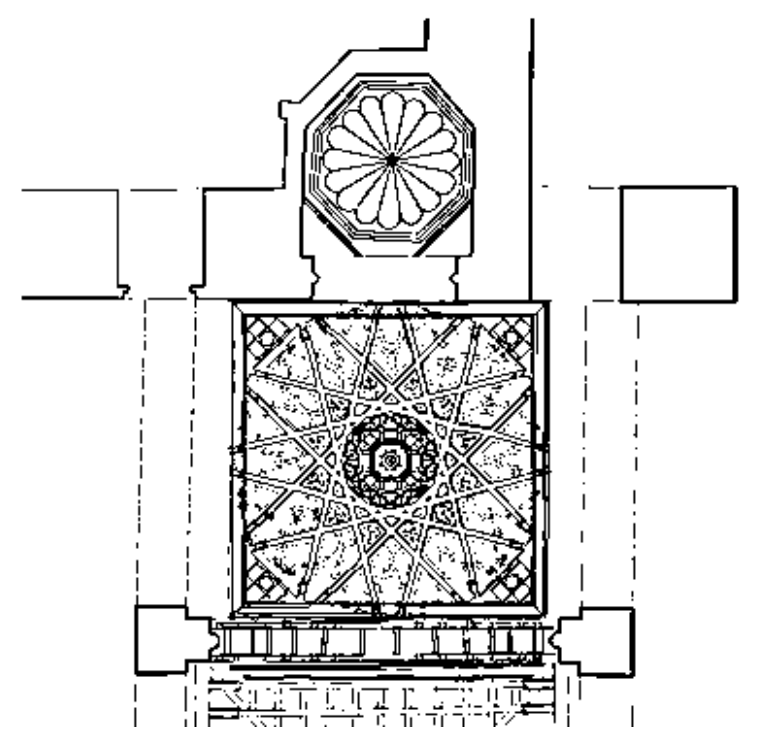

Figure 118: Tlemcen Domes Plan

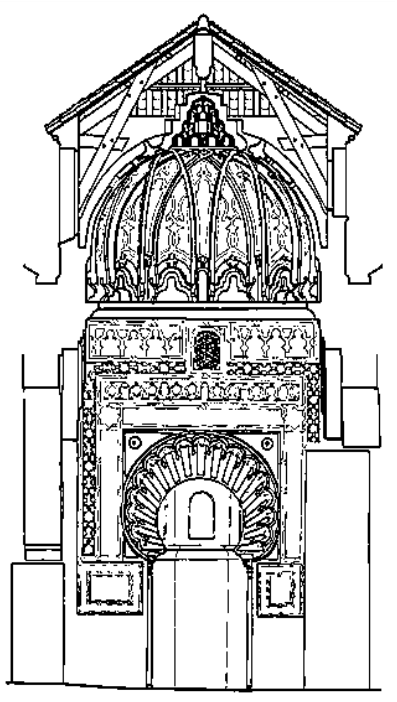

Figure 119: Tlemcen Mosque Section 
Figure 120: Al Maqsura Dome, 1082AD

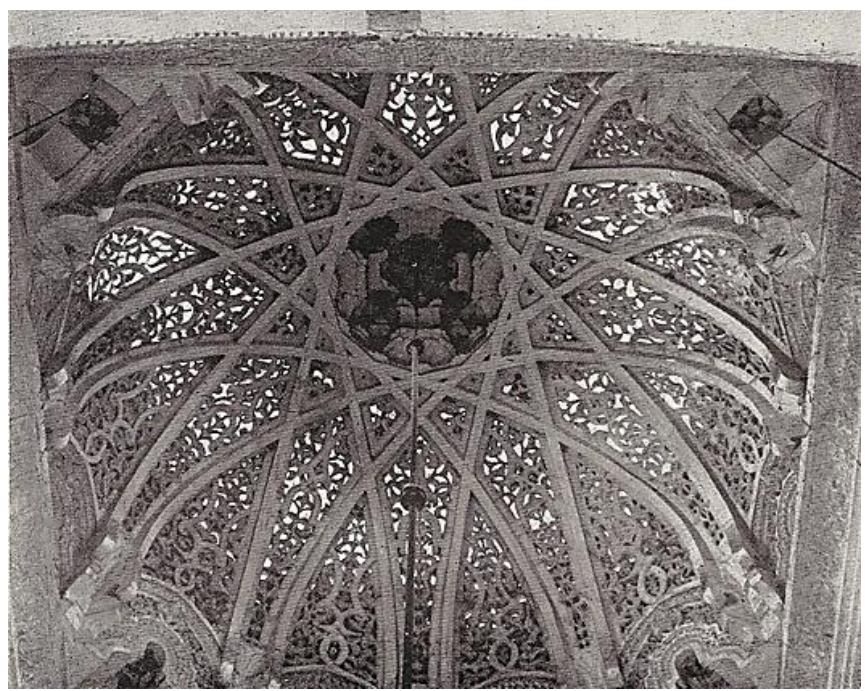

Figure 121: Al Maqsura Dome, 1082AD

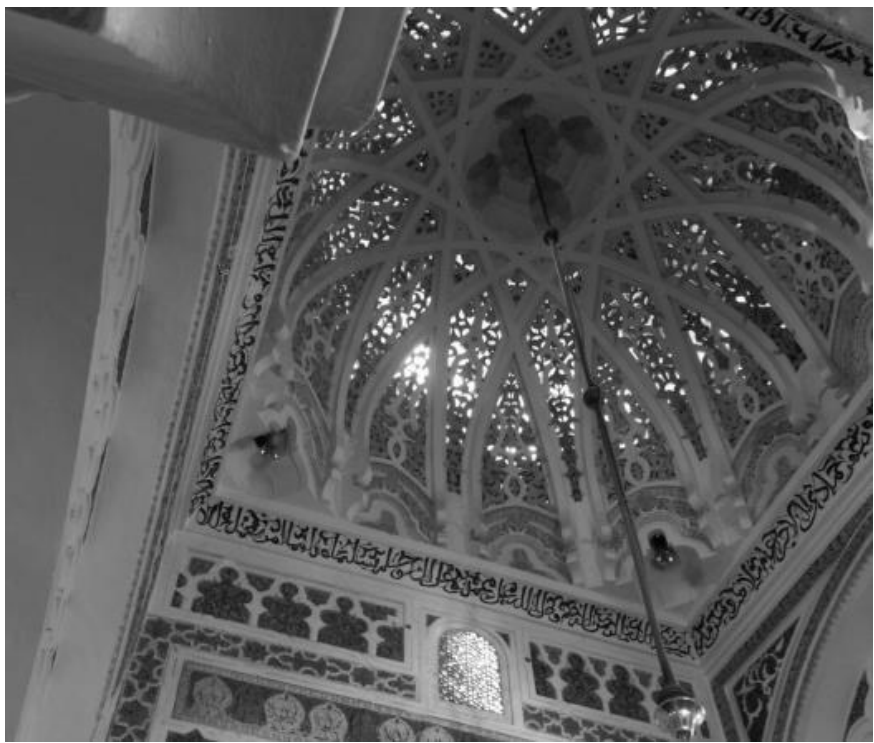

Figure 122: Tlemcen Mosque exterior dome, 1082AD- 1136AD

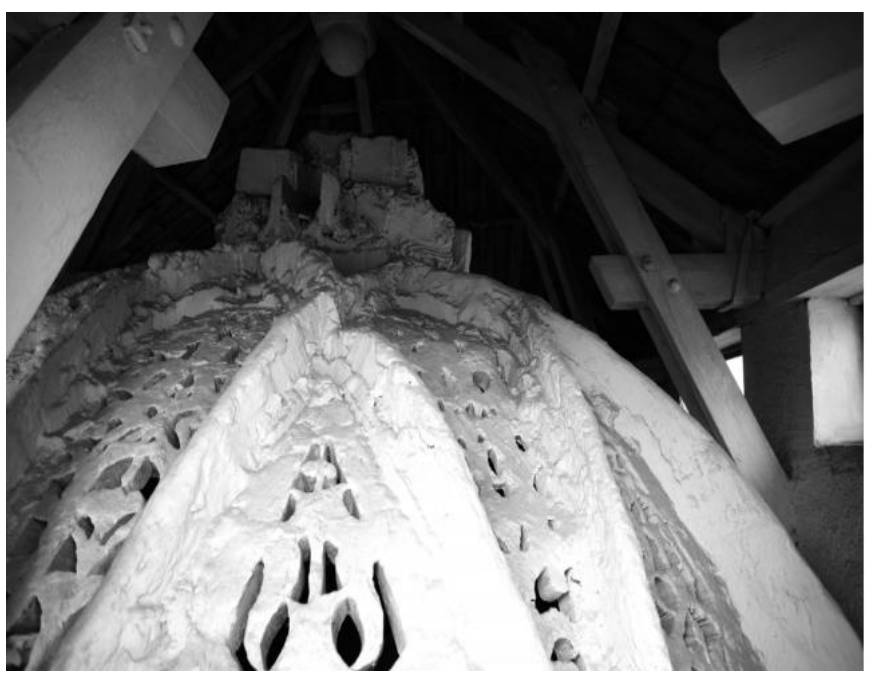

Source: Al-Qantara XXXVI 1, 2015, pp. 199-257 ISSN 0211-3589 doi: 10.3989/alqantara.2015.007 


\subsubsection{Marrakesh Introduction 1120 until 1184 AD}

Qubbat $^{23}$ Albarudiyyin is two-storey kiosk ${ }^{24}$, a separated pavilion open from all sides. This type of architecture [1] [3] (Tabbaa, 2008) famed in Persia named as Cahartaq ${ }^{25}$. The Dome was built in 1120 AD as an ablution fountain for the Moravid Palace, Qasr Al Hajar, when the time Ali bin Yusuf was Emir of the Moravids. Qubbat Albarudiyyin is the square structure with a star-shaped octagon on the inside, which is itself repeated at each of its corners [Figure 125]. The openings of each sides are classic shapes of Al Mohads Architecture and Marinid designs which have outside ribbed arches forming the dome [2]. Later,

The Koutoubia Mosque was built and completed under the reign of the Berber Al Mohad Caliph Ya'qub Al Mansur during 1184 to 1199 AD. It is considered the largest mosque in Marrakesh. It is located in the southwest medina quarter of Marrakesh. The mosque is ornamented with curved windows, a band of ceramic inlay and decorative arches; it has a large court with gardens [3]. The minaret is 77 metres in height, includes a ribbed vault [Figure 130] [Figure 131].

\footnotetext{
${ }^{23}$ Dome

${ }^{24}$ A structure opened from all sides

${ }^{25}$ Four arch building
} [2] (Meunié and

Henry, 1957)

P. 133-146. 


\section{a. Qubbat Albarudiyyin}

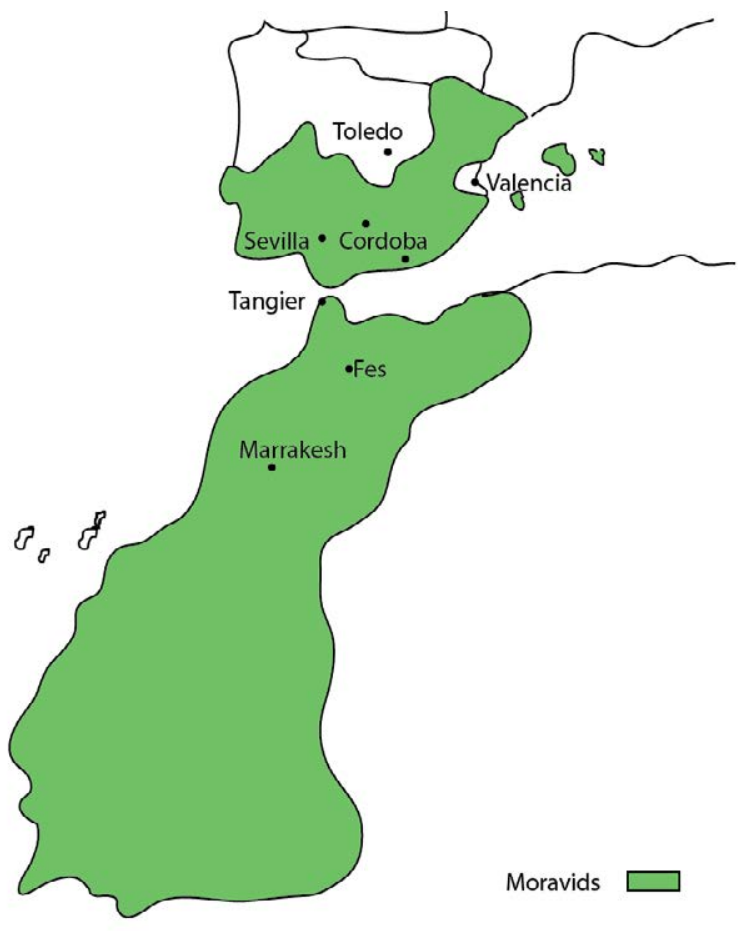

Figure 123: Moravids Dynasty

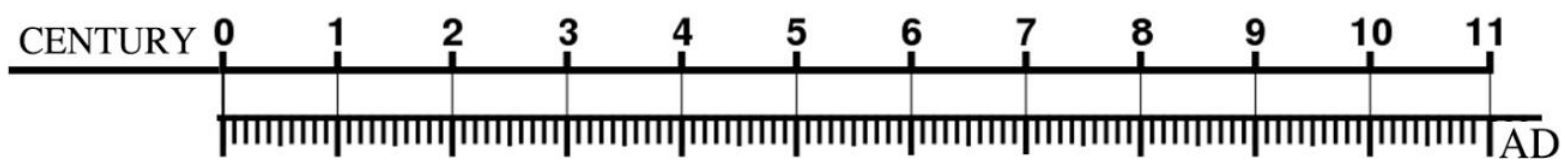

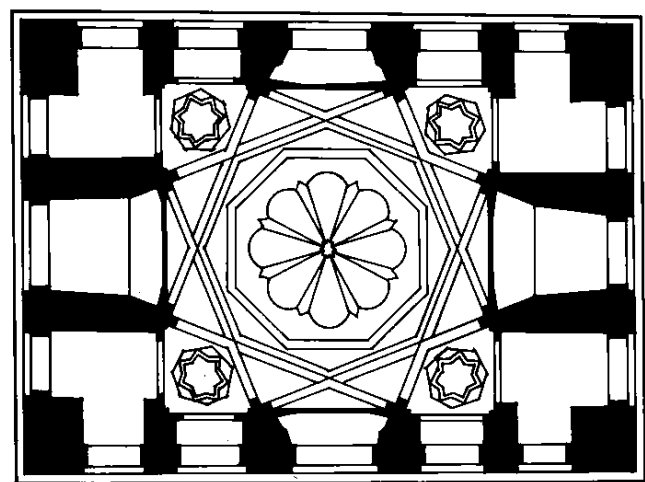

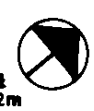

Figure 124: Qubbat Albarudiyyin Plan Source: After Archnet

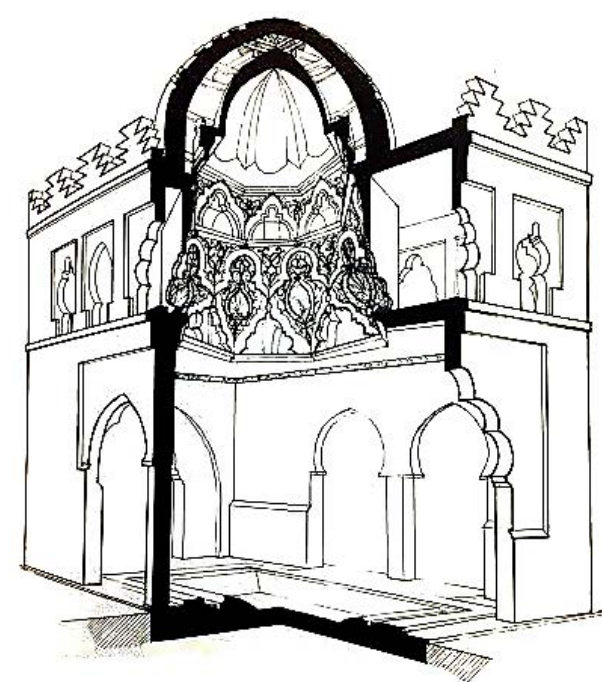

Figure 125: Qubbat Albarudiyyin Perspective Source: After Creswll 


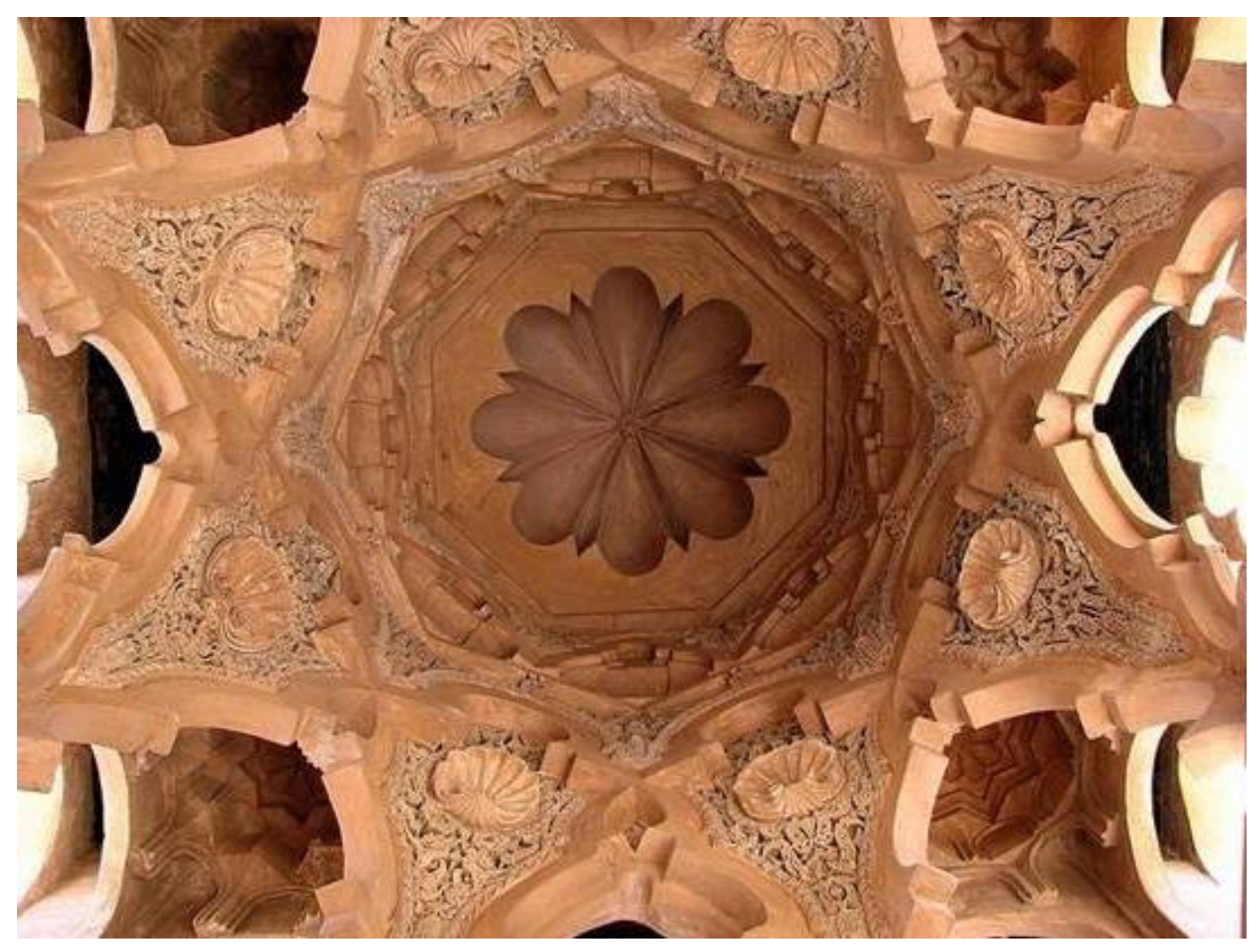

Figure 126: Qubbat Albarudiyyin, 1120 AD

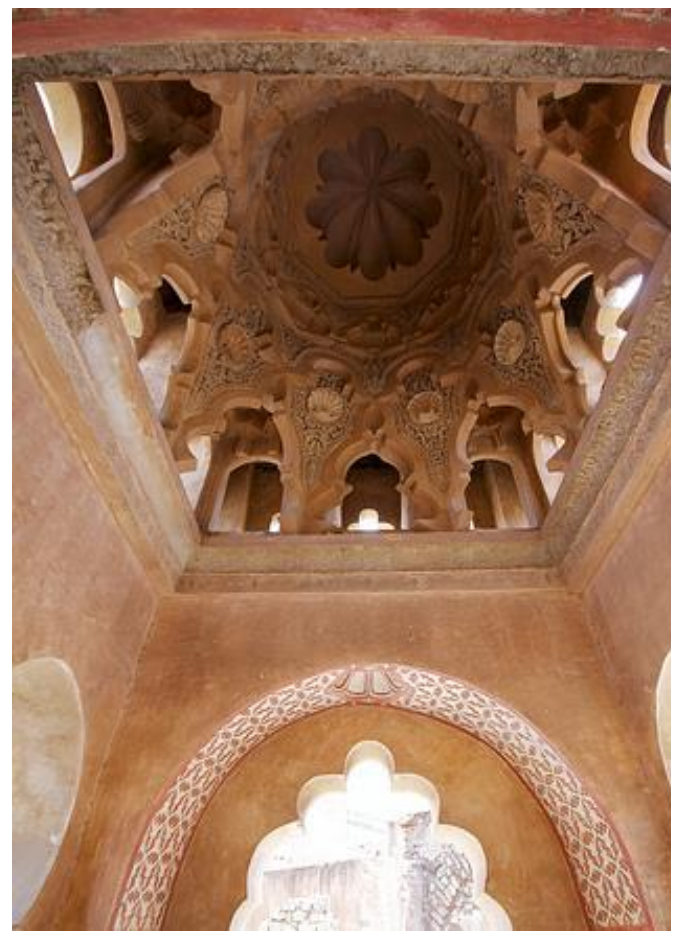

Figure 127: Albarudiyyin View

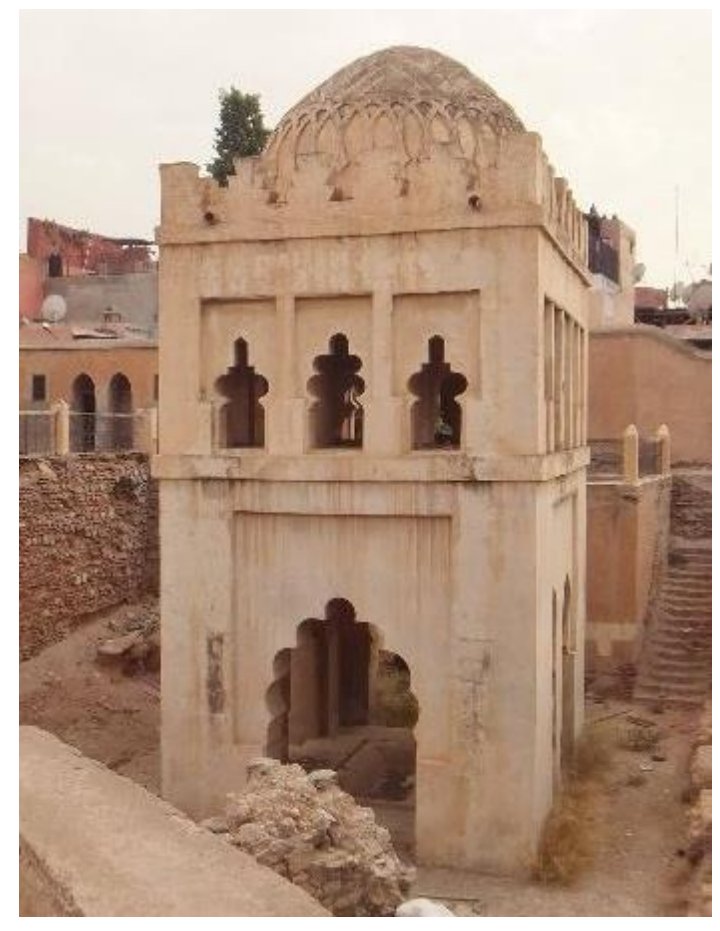

Figure 128: Albarudiyyin Exterior View

Source by: Mike Prince 


\section{b. Kutubia Mosque}

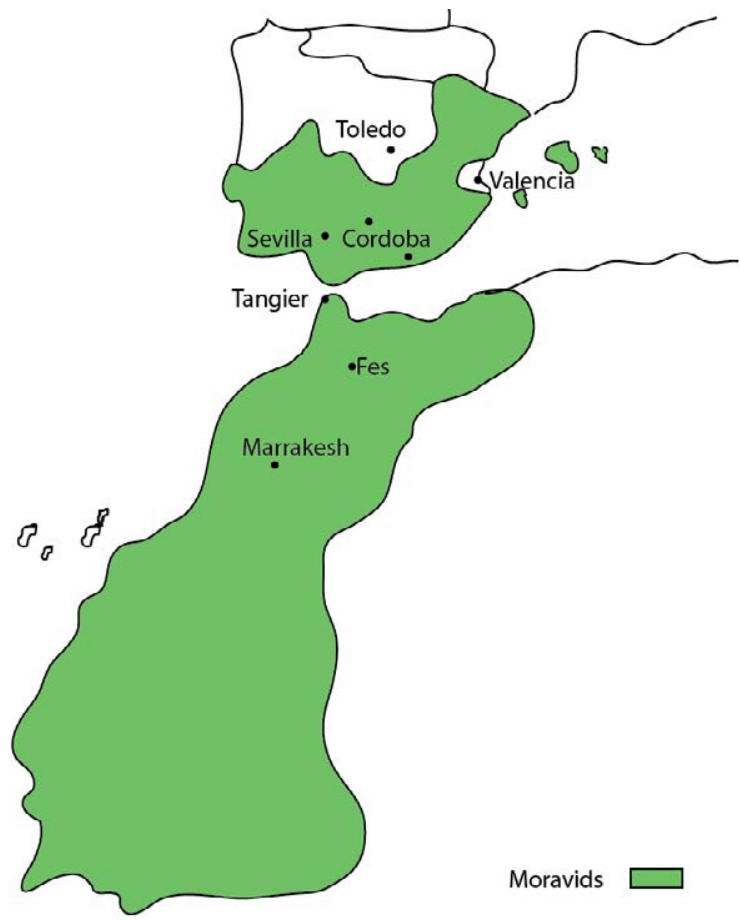

Figure 129: Mohads Dynasty

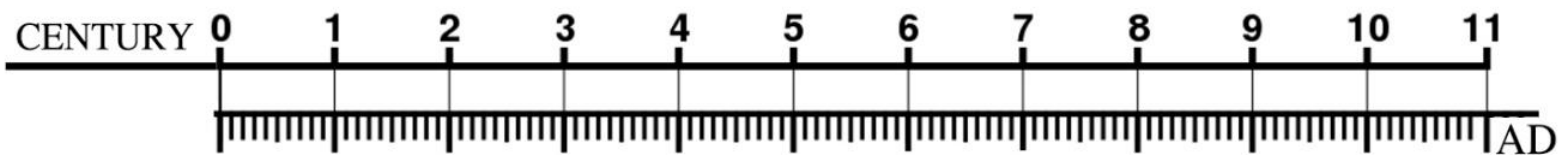

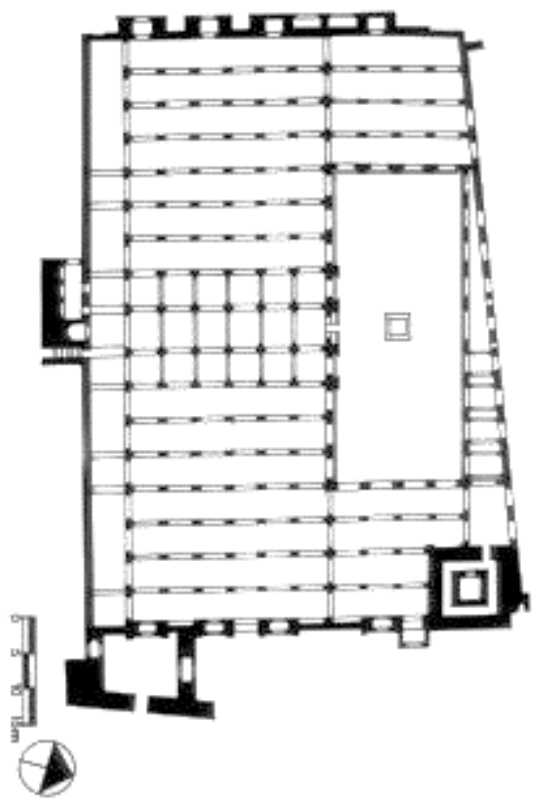

Figure 130: Kutubia Mosque Plan Bult 1184 AD Source: After Archnet

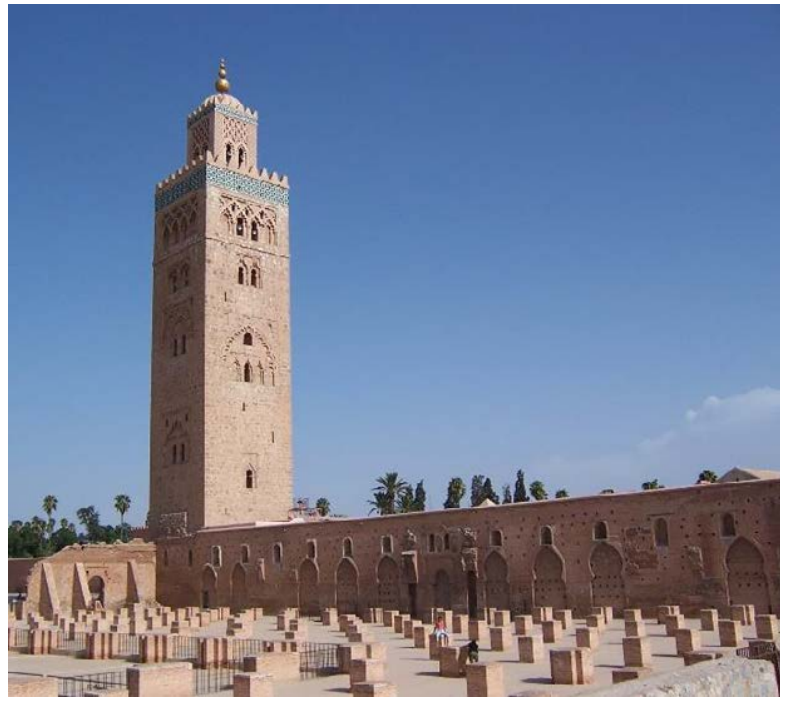

Figure 131: Kutubia Mosque Minartite, Source: After Wikipedia 


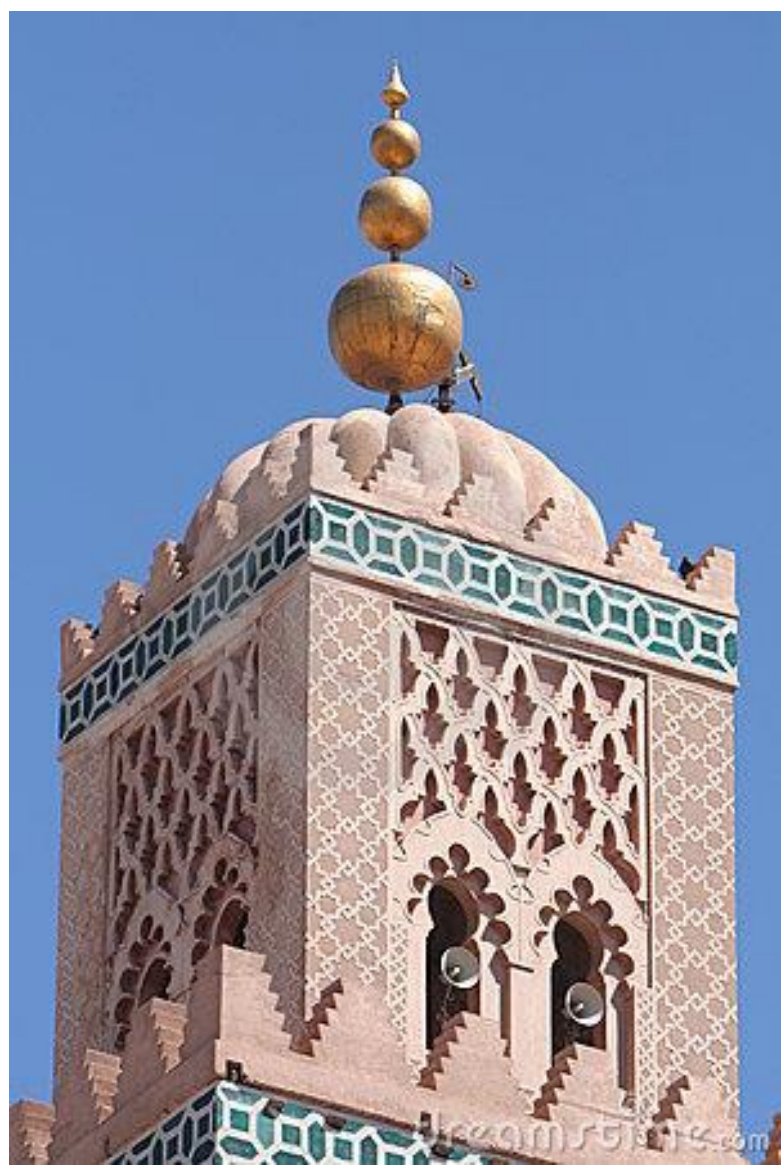

Figure 132: Kutubia Minarte Bult 1184 AD Source: Dreams

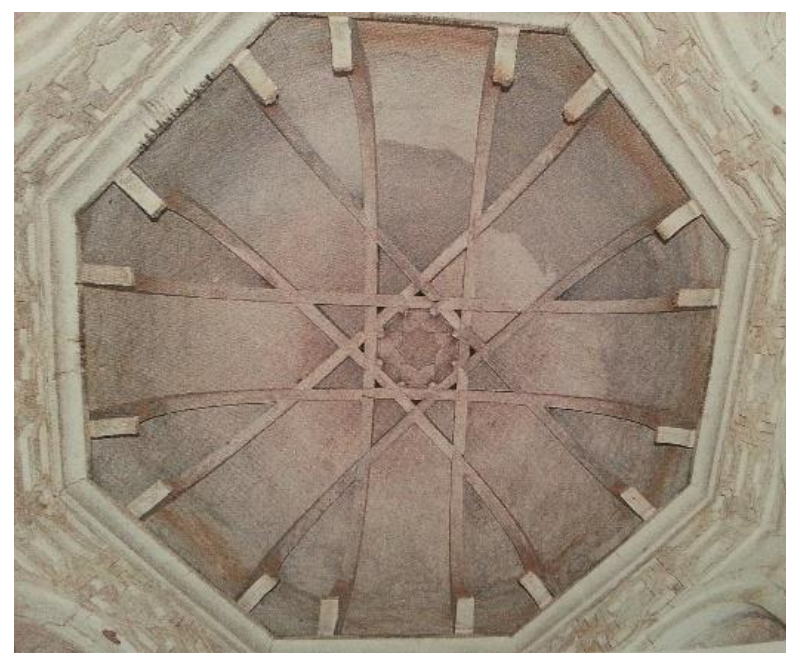

Figure 133: Kutubia Minarite Dome.

Source: After Archnet 


\subsection{Abbasid Era Introduction}

In $747 \mathrm{AD}$, a revolution against the Umayyads Caliphates began in Khorasan then spread until it reached Damascus and demolished the whole dynasty. One of the Umayyad's Emir had escaped to North Africa then Spain where Umayyads continued to rule until 1051 AD [1]. The first three centuries of the Abbasid caliphate considered historically the Golden Age of Muslim civilizations in which Baghdad and Samarra functioned as cultural and commercial capitals of the Islamic world. During this period, a distinctive styles emerged from ancient civilizations and the new Islamic civilization named as: Samara Style [2] [3]. This design method had developed and speared throughout the Islamic expansions. Going back to 750 AD, Abul Abbas, the first Caliph of the Abbasid dynasty had relocated the Islamic capital from Damascus to the heartland of Mesopotamia, Bagdad which is located on the Tigris River side. During which the Umayyads headed west toward North Africa reaching the Mediterranean and Southern Europe, the Abbasids expanded toward the East to Central Asia and got influenced by their culture [4]. In fact, The Abbasid relocation had introduced the Mesopotamian methodologies to Islamic Architecture and eventually developed new Islamic elements to the history of Islamic art by embedding the Sassanids into the Islamic Methods. By the second half of the eight century, new dynasties had been developed in North Africa: The Idrisid, Aghlabids, Rustamid, and Fatimid independent dynasties [5]. All of these dynasties' land were previously Province of the Roman Empire. The massive expansion of the Abbasid Empire resulted into losing the political control of far distant regions, particularly, North Africa and Khorasan in the East. [6]
[1] (Hoag, 1985)

[2] Samarra is located on the east bank of the middle Tigris in Iraq, $125 \mathrm{~km}$ north of Baghdad, Between 836 (221 H) and $892(279 H)$ it was the capital of the Abbasid Caliphs. Samarra expanded to an occupied area of $57 \mathrm{~km}^{2}$, one of the largest cities of ancient times, whose remains of collapsed pisé and brick walls are still largely visible. Samarra is now one of the largest archaeological sites in the world. (Northedge, 2003)

[3] (Gordad,)

[4] (Hillenbrand, 1994)

[5] (Kennedy, 2004)

[6] (Bosworth, 1967) 
Pointing a leader to lead the Islamic caliphates in distant zones consequently developed local independent dynasties.

Each of those Dynasties had developed their own architectural elements. Some were influenced by the region and some were influenced by previous civilizations which invented new arts added to the Islamic context [1].

\subsubsection{The Birth of Abbasid Domes: 755 AD}

A new introduction techniques had been adopted in the Abbasid early architecture. A mixture of mortar and small stones. This method had eased the building method in Islamic Architecture. Al Ukhadir Fortress built in Karbala located in Iraq was the first introduction to the brick vaults in the Abbasids era [Figure 134] [2] [3]. The Ukhadir or Abbasid Palace of Ukhadir erected in 775 AD by Isa ibn Musa. Andrew Petersen had described the Ukhadir Palace in his book: The Dictionary of Islamic Architecture describing:

'It is a common feature of Sassanian and Umayyad architecture in Iraq. The layout of the palace was huge with at least twelve courtyards arranged on a linear plan. At the opposite end of the complex from the kiosk ${ }^{26}$ was a large iwan leading to a cruciformplan audience hall. All of these features are reminiscent of Mesopotamian palace architecture, where palaces are like small cities, containing both administrative and residential areas.' (Petersen, 1996) [4].

The Palace had a great impact on the development of architecture far to North Africa. The architects and masons of Ukhadir introduced a new elaborate technique in the field of vaults building methods called: Fluted Domes [Figure 139]. The old tradition based on the use
[1] (Kennedy, 2001)

[2] El-Hibri, 1999)

[3] (Sicker, 2000)

[4] (Petersen, 1996) P. 140

[5] (K. Hitti, 1956)

\footnotetext{
${ }^{26}$ Four Arched Building
} 
of a mixture of mortar and small stones and rubble lay on wooden base [5]. This old tradition method required wood which is not obtainable easily in the region of Mesopotamia [6] [7]. For this, the initial start of using non- centring vaults were established. This new technique to the Islamic Architecture, likely to have been introduced through Persian and Mesopotamian, which have provided adequate solutions in building vaults.

Rafique Ali Jairazbhoy in his book: Outline of Islamic Architecture described the vaulting construction methods as:

'Further elaboration of the vault construction technique was made in the Palace's mosque, through the use of fluted arches to support the brick vault, a technique which became known as ribbed vaulting.' (Jairazbhoy, 1972)

According to Marcais in 1954, he clarified that the ribbed vault

[1] (Jairazbhoy, 1972). achievement was the foundations for the rise of Gothic Vault architecture in Europe [2].

[2] (Marcais , 1883) 


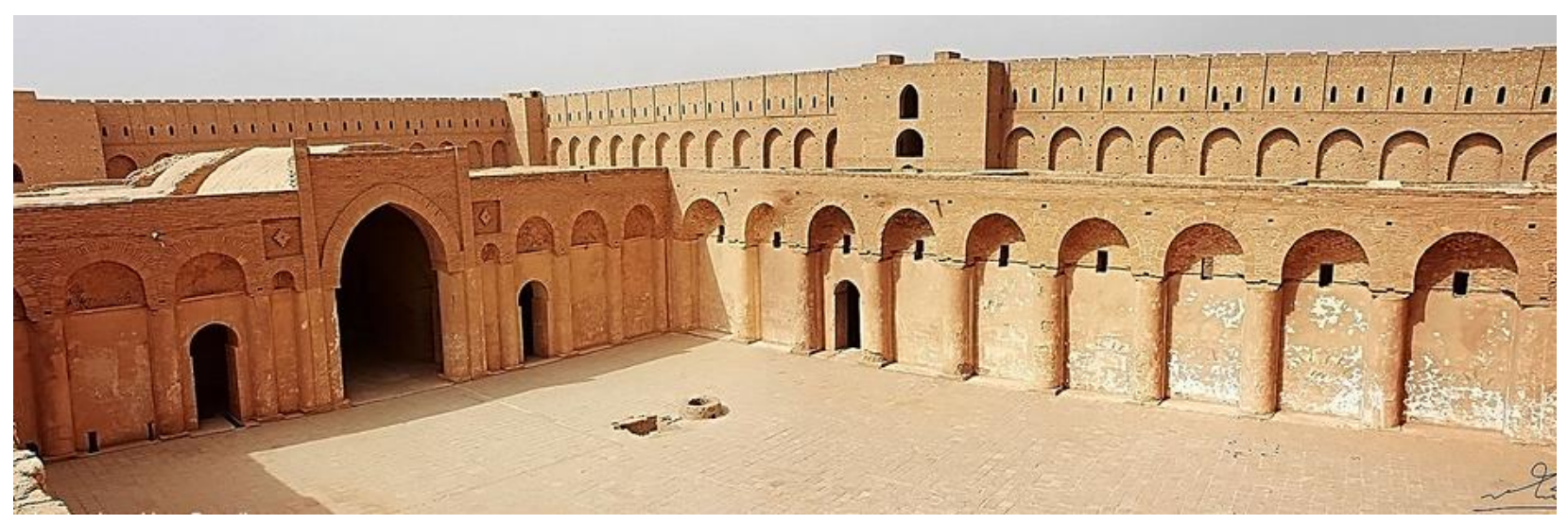

Figure 134: Ukhadir Fortress, Karbala in 775 AD

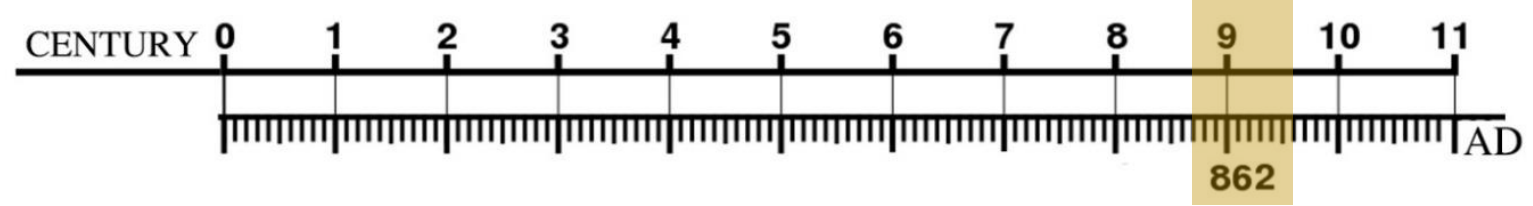

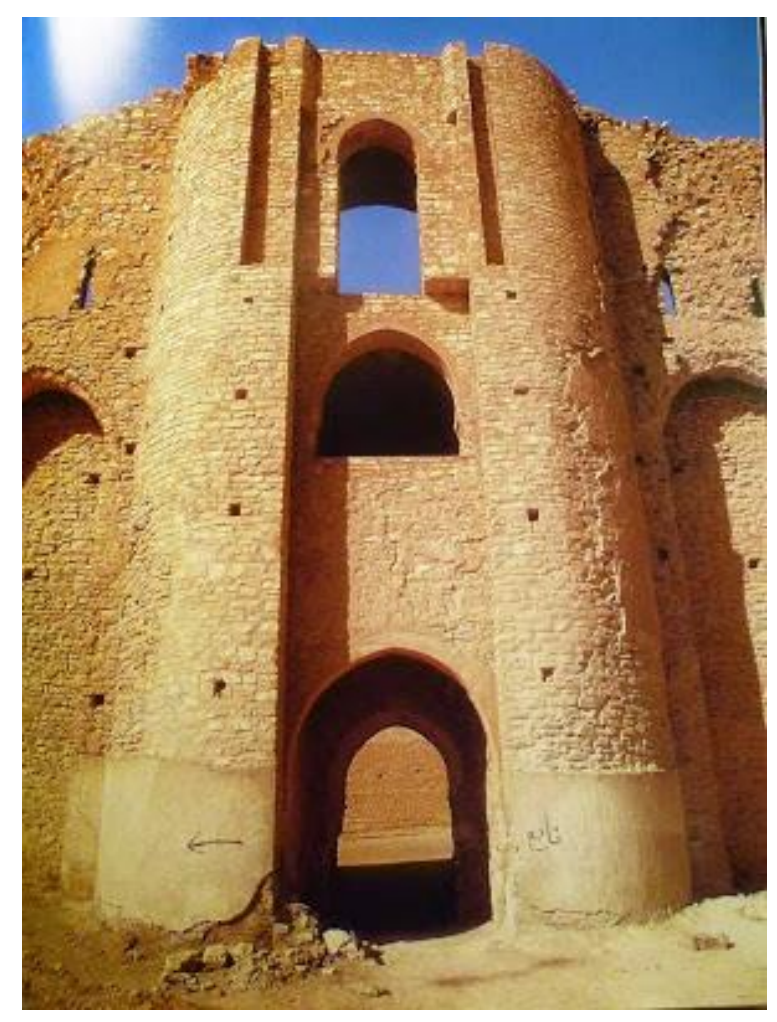

Figure 135: Ukhadir Entrance

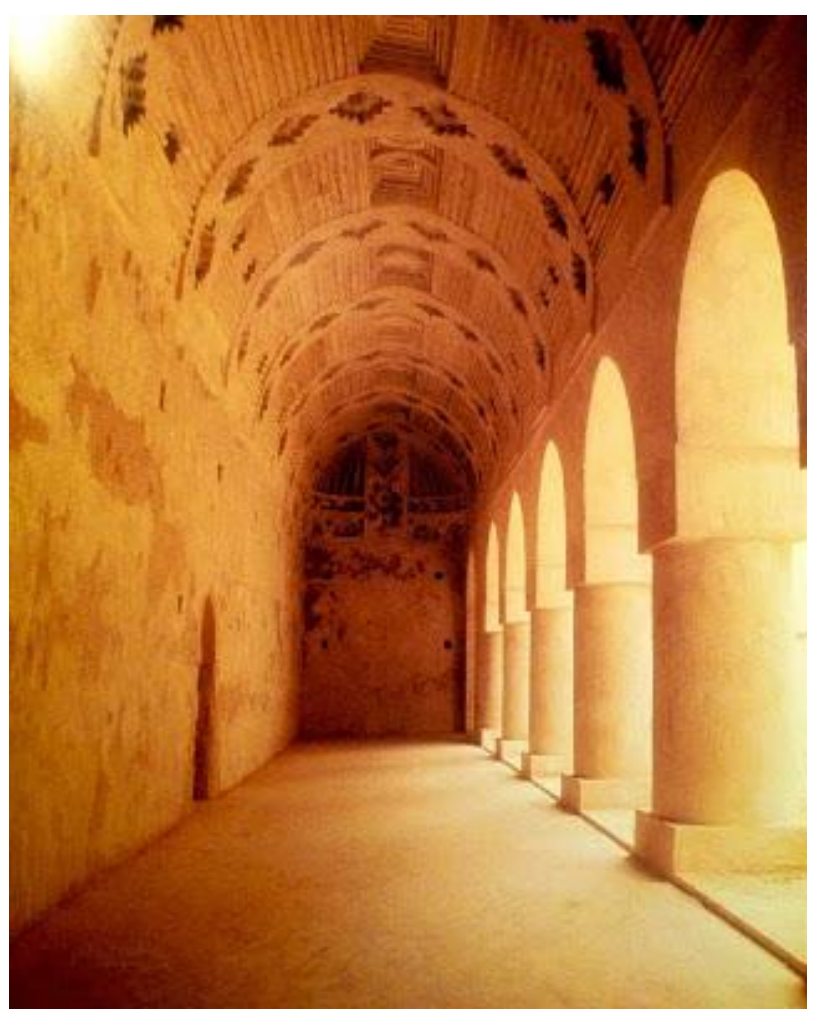

Figure 136: Ukhadir barrel Vault 


\subsubsection{Abbasid Domes in Iraq}

a. Ukhadir Fortress, Karbala: 762 AD

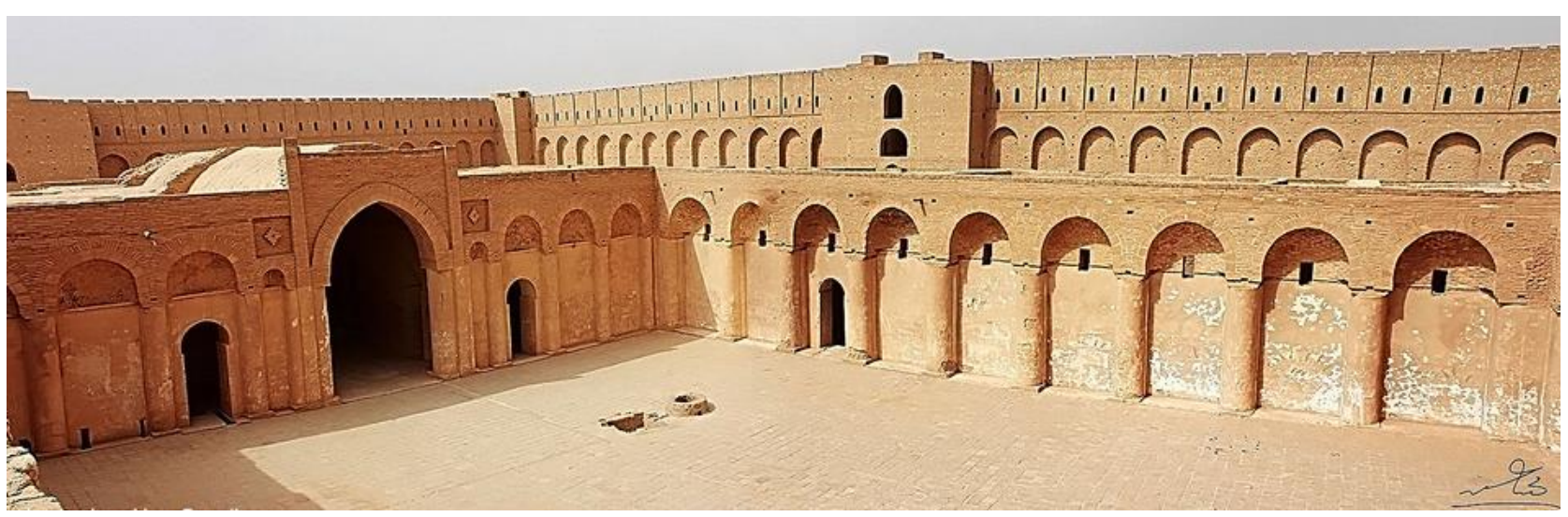

Figure 137: Ukhadir Fortress

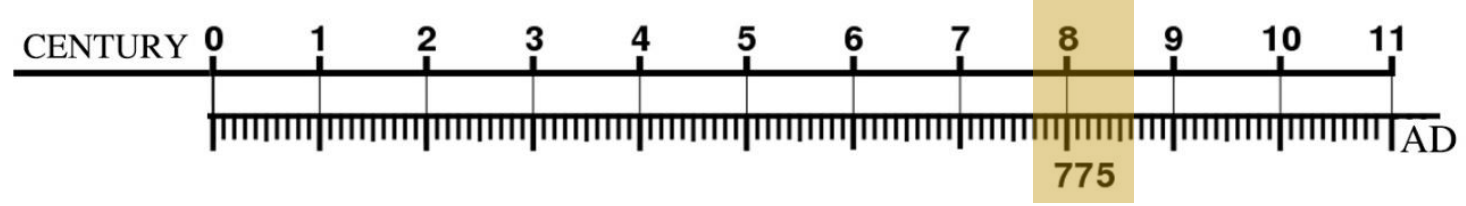

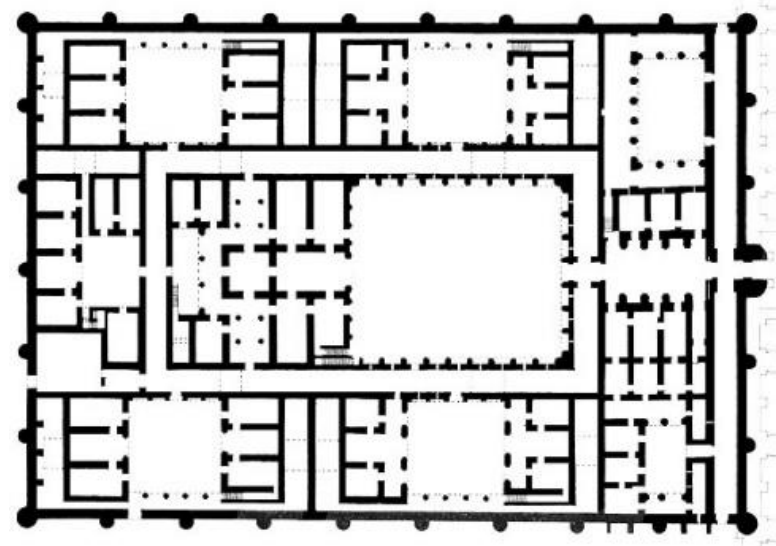

Figure 138: Ukhadir Fortress Plan, 775 AD, Source: Archnet

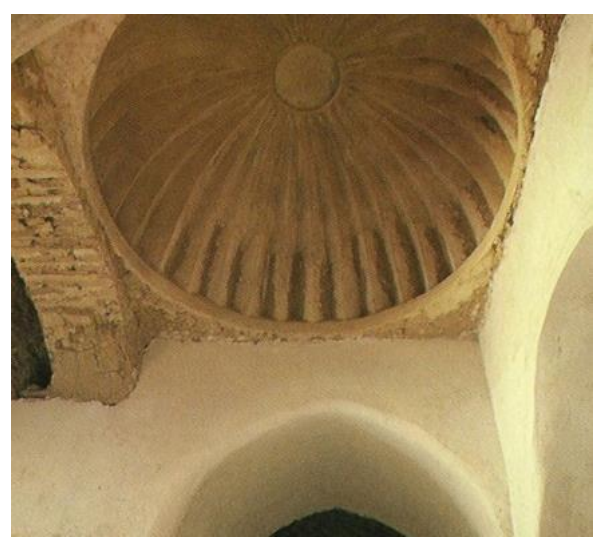

Figure 139: Ukhadir Zigzag Dome

Source: Hattstein and Delius (2000), p. 100. 
By the expansion of the Abbasid Caliphates, new architectural structures were added to the Abbasid culture to honer Abbasid Caliphates by building Mausoleum. Al Sulaybiyya Mausoleums considered the first Islamic Mausoleum structure [Figure 141]. It was built over a hill site on the western shore of the Tigris River to honour the death of the Abbasid Caliph, Al Muntasir, who ruled during: 861 until $862 A D$. In 862 AD, his Mausoleum was erected in Samarra, Iraq [Figure 140]. An octagonal structure with a central egg dome settled on a drum with squinches [Figure 142]. The center of the structure is a square room contains the tomb of Al Muntasir and later other succeeding caliphs, Al Mu'tazz and Al Muhtadi, were also buried in the same site.

The octagonal shape has three zones: an outer octagon, an inner octagon, and a central square chamber. A vaulted walkway with sixteen transverse arches runs between the two outer octagons [Figure 143]. Each facade of the outer walls feature an arched doorway. There are only four entrances to the Tombs. It is the first Abbasid building of its type to use an octagonal hallway. Such a building tradition was previously known in Umayyad's periods only [1] [2].

[1] (Creswell, 1989)

[2](Richard Ettinghausen, Grabar Oleg, and Blair Sheila, 1987) P.148-150 


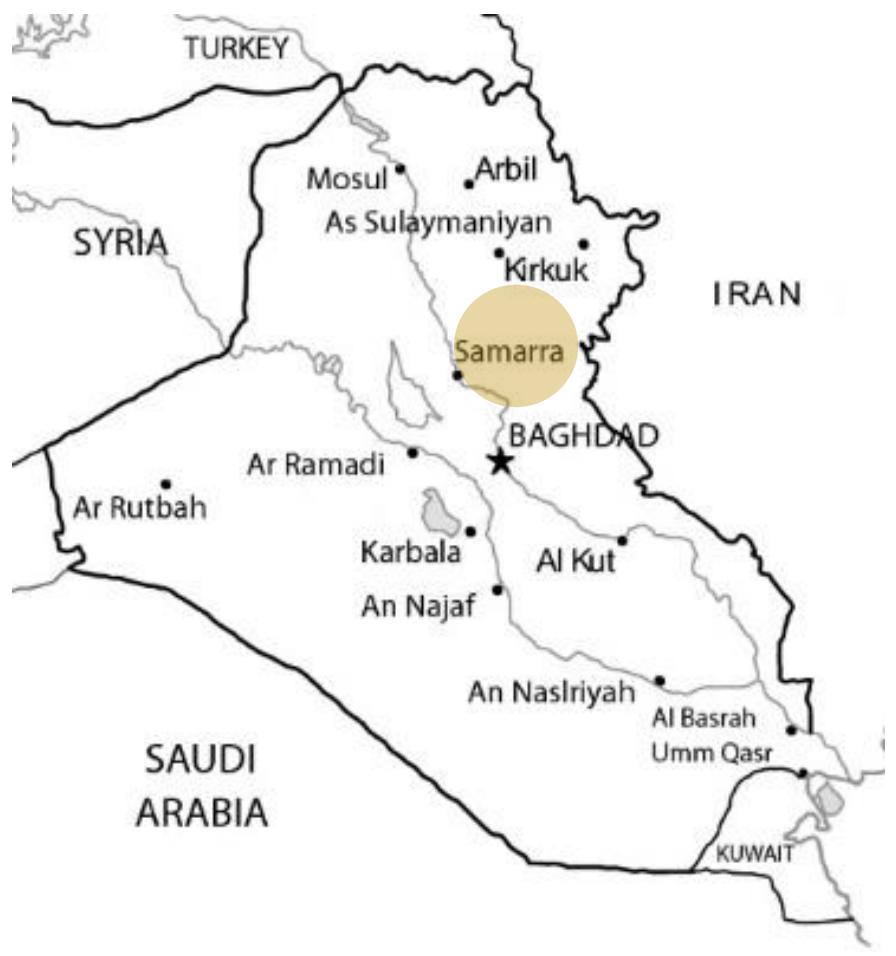

Figure 140: Qubbat Al Sulaibiya Location, Iraq

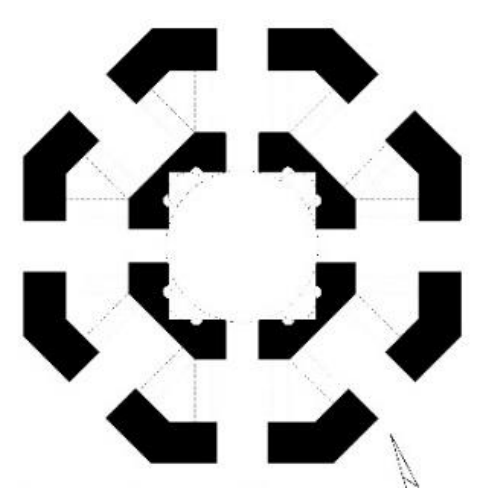

Figure 141: Qubbat Al Sulaibiya Plan , 862 AD

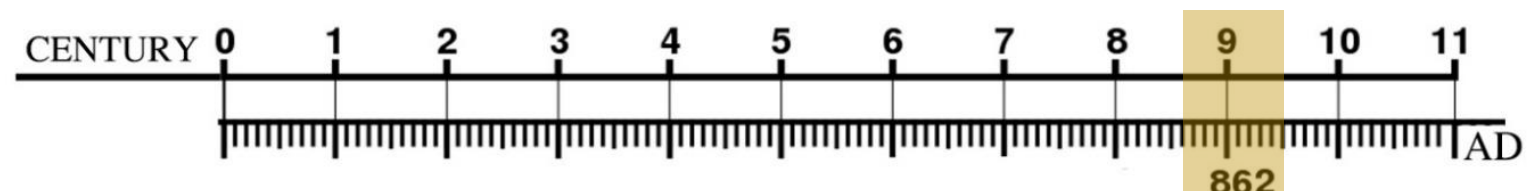

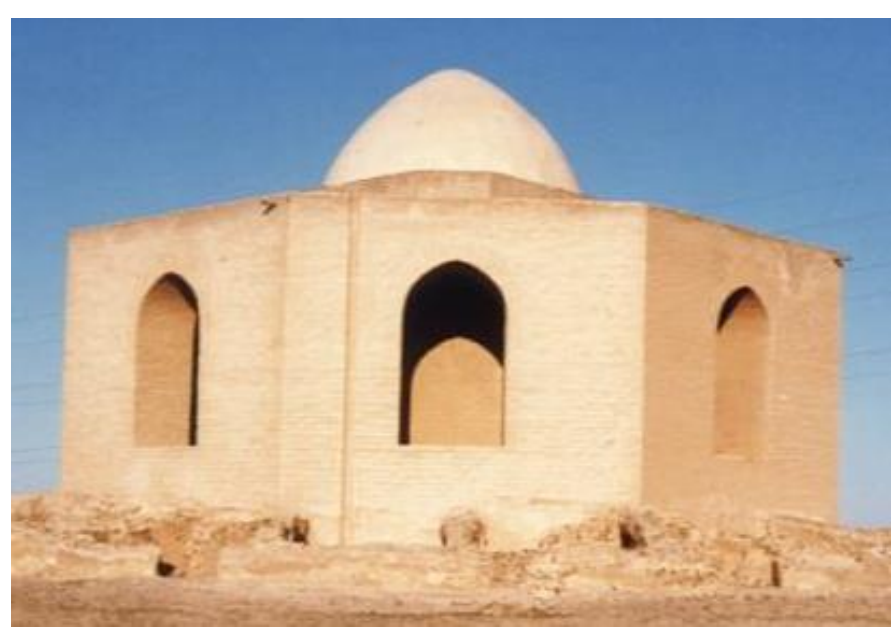

Figure 142: Qubbat Al Sulaibiya, 862 AD

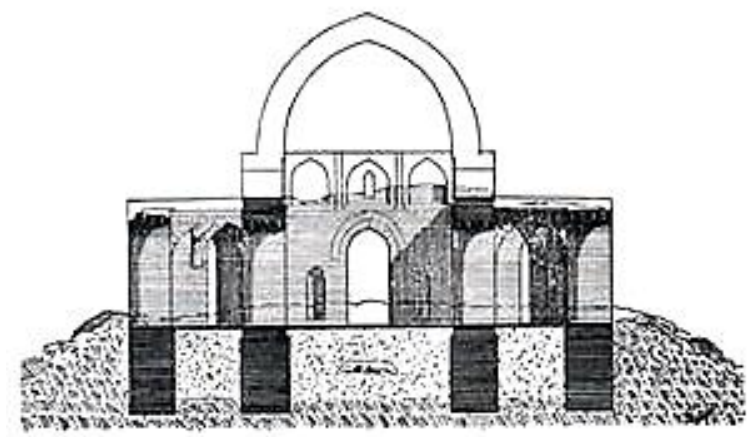

Figure 143: Qubbat Al Sulaibiya, 862 AD

Source: Archnet 


\subsubsection{Abbasid Introduction in North Africa}

In North Africa, Idrisid, Aghlabids then Fatimid caliphates arose during the Abbasid period. Some resisted rule by Arabs and established their own, and some did not except Arabs to rule their dynasties and remained independent.
i. Idrisid in Fes: 788-974 AD
ii. Aghlabid governor of Kairouan: 800-901 AD
iii. Rustamid: 767-788 AD
iv. Fatimids Zirids: 973
v. Independent Zirids: 1048 - 1146 AD
vi. Fatimids : 909- $1171 \mathrm{AD}$

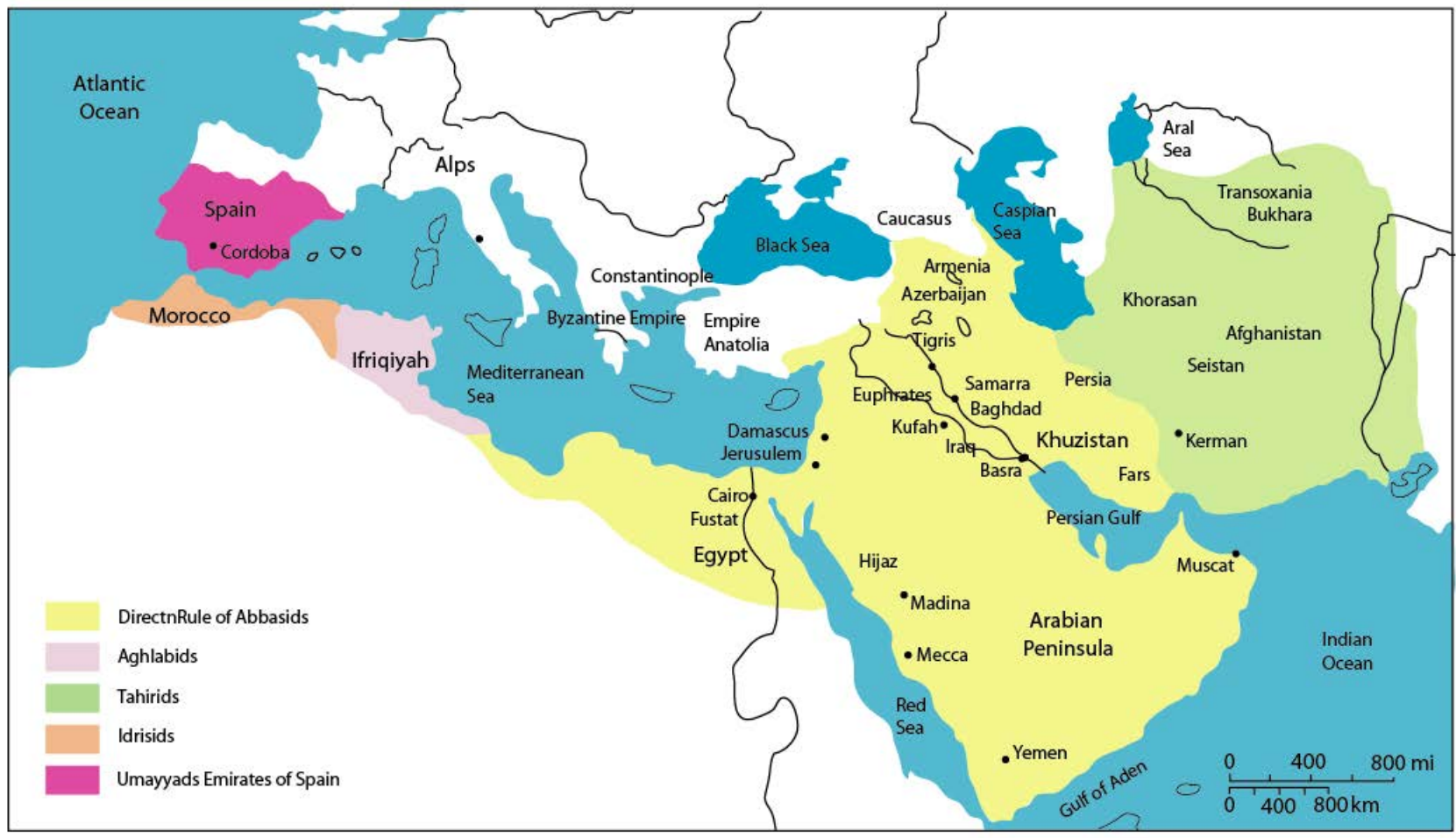

Figure 144: Islamic Dynasties, Abbasid Era 
In certain Period, North Africa served as a transit region for people moving towards Europe or the Middle East. The region was influenced by previous Civilizations from other centuries including Carthaginians, Romans, and Vandals. The massive expansion of the Abbasids Empire resulted into losing the political control of far distant regions, particularly North Africa, Egypt. Therefore, local dynasties claimed new dynasties and created their own art.

Previous Civilizations in North Africa

\begin{tabular}{|l|l|c|c|c|c|c|}
\hline $\mathbf{C .}$ & $\begin{array}{l}\text { North } \\
\text { Morocco }\end{array}$ & Tunisia & Egypt & Spain & Central Asia & Persia \\
\hline $\mathbf{6}^{\text {th }}$ & Byzantine & Byzantine & Egypt & Goth & Zoroaster & Sassanids \\
\hline $\mathbf{7}^{\text {th }}$ & Umayyad & Umayyad & Roman & Goth & Umayyads & Sassanids \\
\hline $\mathbf{8}^{\text {th }}$ & Idrisid & Abbasid & Umayyad & Umayyad & Abbasids & Abbasids \\
\hline $\mathbf{9}^{\text {th }}$ & Idrisid & Aghlabid & Abbasid & Umayyad & Tahirids & Buyids \\
\hline $\mathbf{1 0}^{\text {th }}$ & Barber & Fatimid & Tulunid & Umayyad & Seljuk & Seljuk \\
\hline
\end{tabular}

Table 4: Previous civilizations in North Africa 


\begin{tabular}{|c|c|c|c|c|c|}
\hline Capital & Western Magrib & Year & Capital & Eastern Magrib & Year \\
\hline Fes & Idrisid & $789-926$ & Kairouan & Aghlabid & $800-909$ \\
\hline North Algeria & Rustamid & $777-909$ & Mahdiya & Fatimid & $909-1171$ \\
\hline Marrakesh & Moravid & $1056-1147$ & Tunis & Zirid & $972-1148$ \\
\hline Marrakesh & Almohad & $1130-1269$ & $\begin{array}{c}\text { Beni Hammad } \\
\text { Algeria }\end{array}$ & Hammadid & $1015-1152$ \\
& & & Tunis & Hafsid & $1228-1574$ \\
\hline Fes & Marinid & $1196-1465$ & A & & \\
\hline
\end{tabular}

Table 5: West and East Islamic Dynasties in North Africa

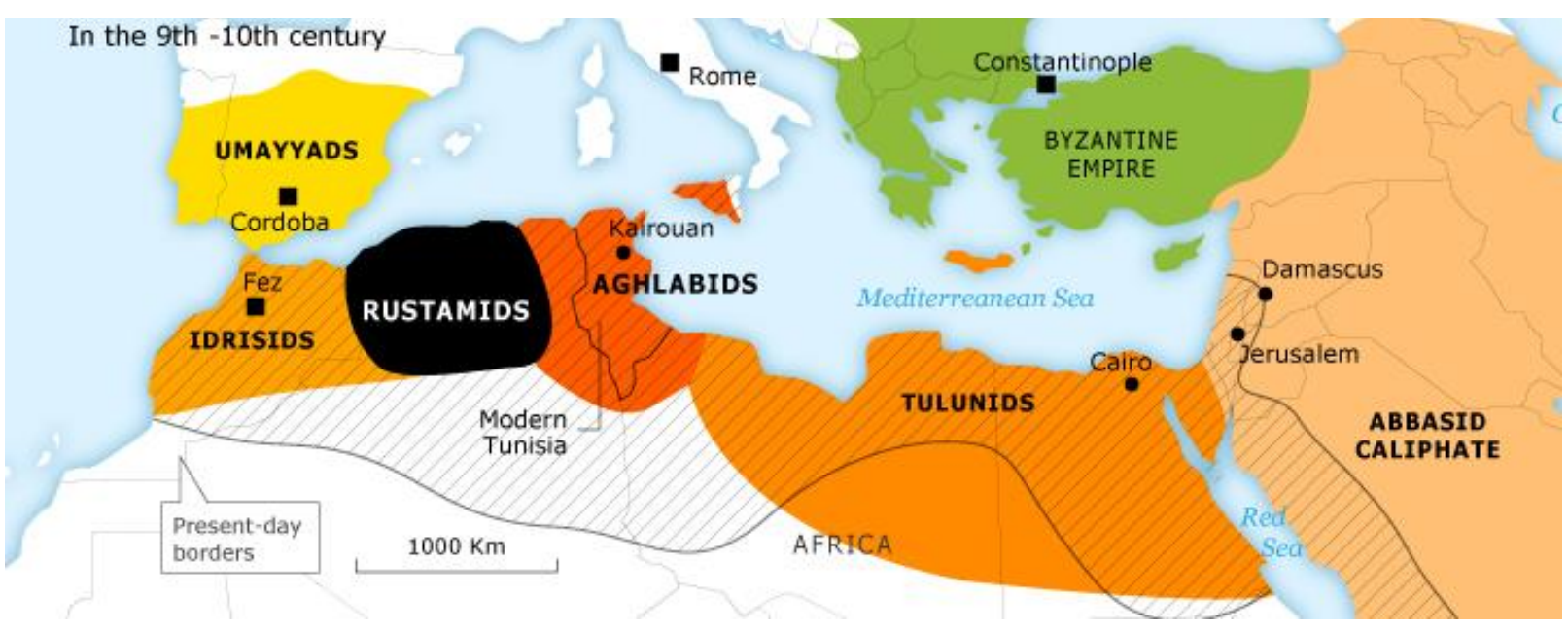

Figure 145: Islamic Dynasties during, 9th- 10th Centuries, After

Source: Attwiw

\begin{tabular}{|c|c|c|}
\hline Capital & Egypt & Year \\
\hline Fustat & Tulunid & $868-905$ \\
\hline Cairo & Ikhshidid & $935-969$ \\
\hline Cairo & Fatimid & $969-1171$ \\
\hline Cairo & Ayyubid & $1171-1250$ \\
\hline Cairo & Mamluk & $1250-1517$ \\
\hline
\end{tabular}

Table 6: Dynasties during, 9th- 10th Centuries in Egypt 


\subsection{Idrisid Introduction: 788-791 AD}

The Idrisid of Arab origin, historically considered the founders of Moroccan State. Idrisid belong to Zaydi Branch of Shiite ${ }^{27}$. They are considered the oldest and largest group among Shiite. Idris Ibn Abdallah, the founder of Idrisid Dynasty was from Ali ibn Abi Talib ${ }^{28}$ origin, the cousin and son-in-law of the Prophet of Islam Mohammad. After the battle between Abbasids and Shiite party, Idris had escaped to Maghreb ${ }^{29}$ arriving to Tanga then moved to Volubilis, which was an excavated Roman city located between Fes and Rabat in Morocco. By then, $A w r a b a^{30}$ Berber tribe made Idris I their Imam ${ }^{31}$. He managed to expand his Dynasty until Tlemcen City located in North-Western Algeria. Then started forming Fes City but he got poisoned by ab Abbasid agent assigned by Haroun Al Rashid in 791 AD [Figure 146]. His son, Idris II, had unified Morocco under Islam and developed the city of Fes during 791 and until $828 A D$, which resulted into the need of building a mosque for the city named by, Mosque Al Ashyach, which was converted in to a Mausoleum for Idris I.

Fes City is divided into two quarters. The first quarter called: $A$ I Andalusian, which was named by the name of the refuges from Cordoba to Fes after the revolution against the Umayyad Emir of Cordoba, Al Hakam bin Hisham who was famed as Al Hakm I [1]. This revolution resulted into the immigration of eight hundred Andalusian families to Fes including some Berber descent during the period of 817-818 AD [2].
[1] Al Hakm I had ruled from 796 until 822 AD While

Al Hakam II had ruled from 961 to $976 A D$

[2] (Mohammad, xxx)

\footnotetext{
${ }^{27}$ Islamic movement supporting Ali, the cousin and son-in-law of Muhammad

${ }^{28}$ The cousin and son-in-law of the prophet of Islam, Muhammad

29 The region of Northwest Africa, or west of Egypt

30 Tribe were originally from Tlemcen City located in North-Western Algeria

${ }^{31}$ Religious leader
} 
The second quarter of the City called Al Qarawiyyin: where Idris had settled at first. A rebellion occurred in Kairouan City in Tunis and resulted into the emigration of two thousand Arab families to the Qarawiyyin quarter in Fes during 824 AD. This requested a need for another mosque in the area named as, Al Ashraf ${ }^{32}$. The majority population in Fes City were of Arab descent, and the minority were of North African Berber descent, with rural Berbers from the surrounding countryside settling mainly in the Andalusian quarter of Fes City. During the immigration of the Kairouan inhabitant to Fes, a wealthy family named Al Fheri, consists of a father and two daughters named: Fatima and Maryam. When their father died, he left behind a massive amount of money. Fatima decided to build a mosque in Qarawiyyin Quarter and her sister Maryam constructed another one in the Andalusian Quarter [Figure 147]. Al Qarawiyyin Mosque was built and associated with University, founded in 859 AD. While the new Andalusian inhabitants participated in constructing Maryam's Mosque in The Andalusian Quarter in 859 AD [1] [2]. Mohammed in his book Fes City mentioned:

'The Dome of al Mihrab in The Qarawiyyin Mosque was built 778AD but rebuilt again in 899 AD.'

And added

'With the arrival of the Mohads, Caliph Muhammad Al Nasir in 1199-1213 AD, who had a particular interest to Fes City. He had built the north facade crowned with two domes, one in sculpted plaster and the other in cedar wood.' [4]
'There were extensive renovations in $956 \mathrm{AD}$ by the Umayyad caliph of Spain who also added the minaret.' (Petersen, 1996) P. 87

[1] (Hillenbrand, 1994)

P. 240-251.

[2] (Hoag, 1987)

P. 57-59

[4] (Mohammad, xxx)

[5] (Marcais, 1955)

P. 197-200.

\footnotetext{
${ }^{32}$ means the glory of the honourable
} 
At the end of the tenth century, specifically in the year 899 AD. A dome was built at the entrance to the central nave of the mosque.

Although there is no clear text describes the dome, but the simplicity [1] (Hillenbrand, 1994) of the architecture of this period allows to say there were no cross vaults carried out. Without a doubt, Al Qarawiyyin Mosque was the P. 240-251.

[2] (Hoag, 1987)

P. 57-59

first mosque to use domes on the central naves to emphases the accesses to Mihrab, covered with different type of domes along the [3] (Marcais, 1955) P. 197-200. direction of Qibla [ Figure 152] [1] [2] [3] [4].

[4] (Michell, 1996)

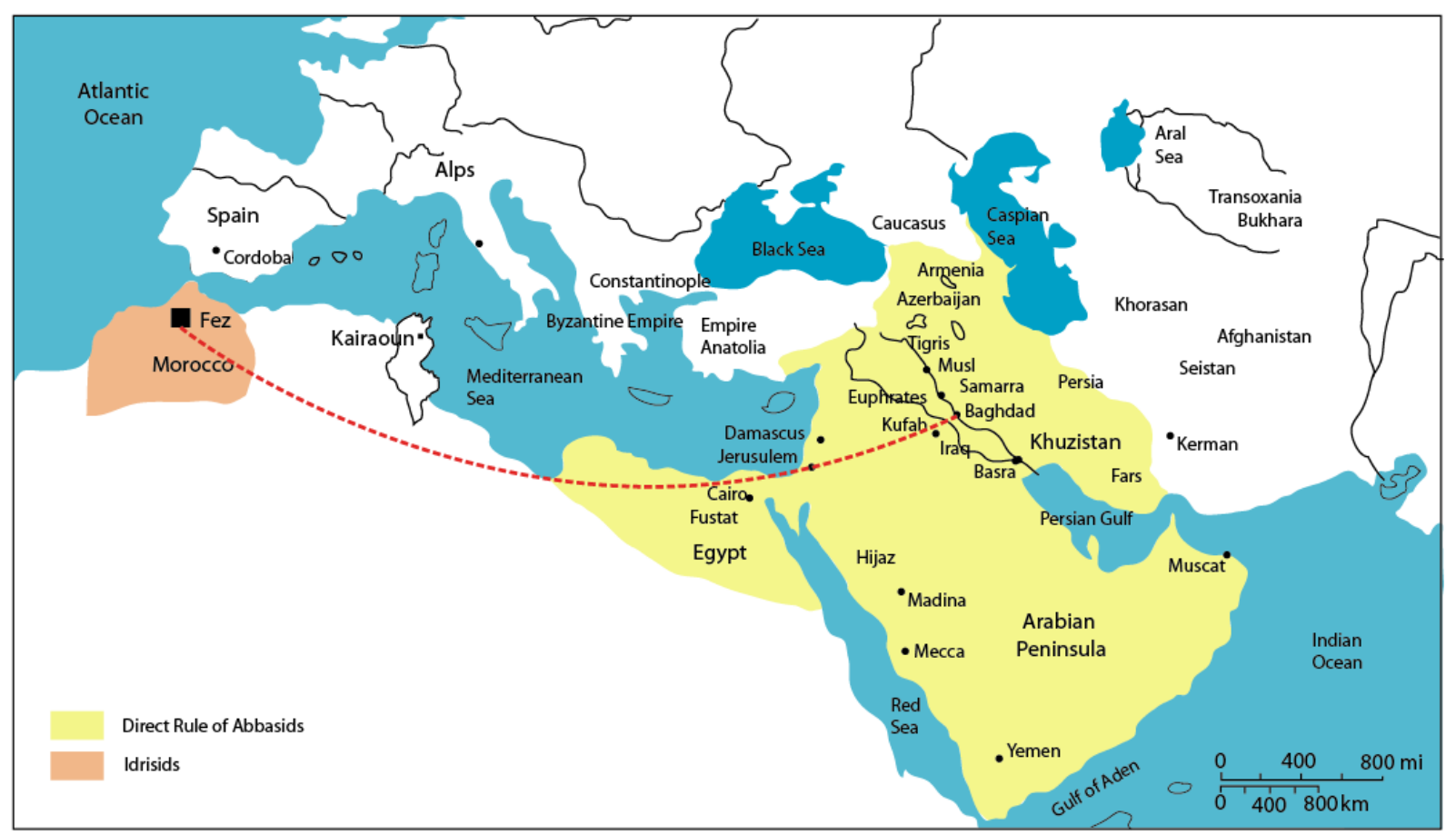

Figure 146: Idrisid Dynasty, 788-791AD 
a. Al Andalus Mosque

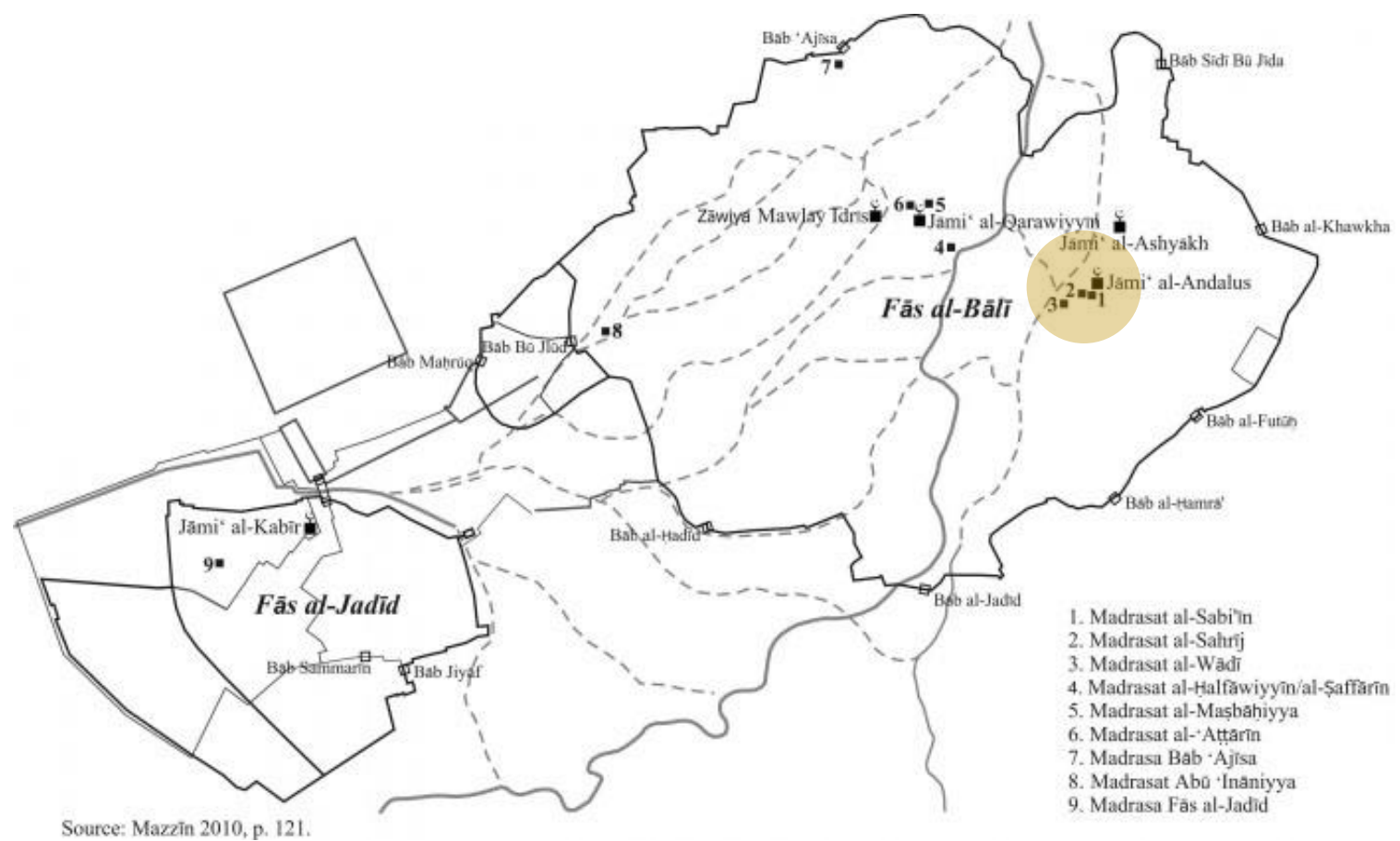

Figure 147: Andalus Quarter

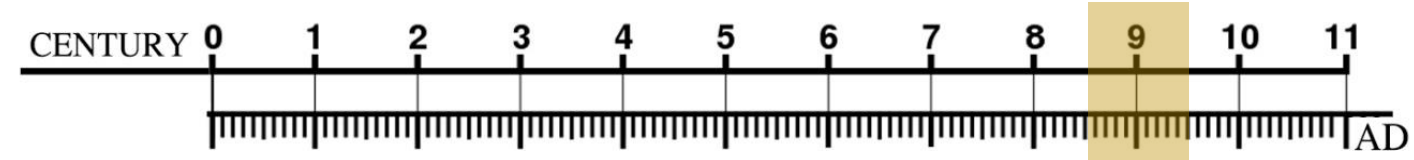

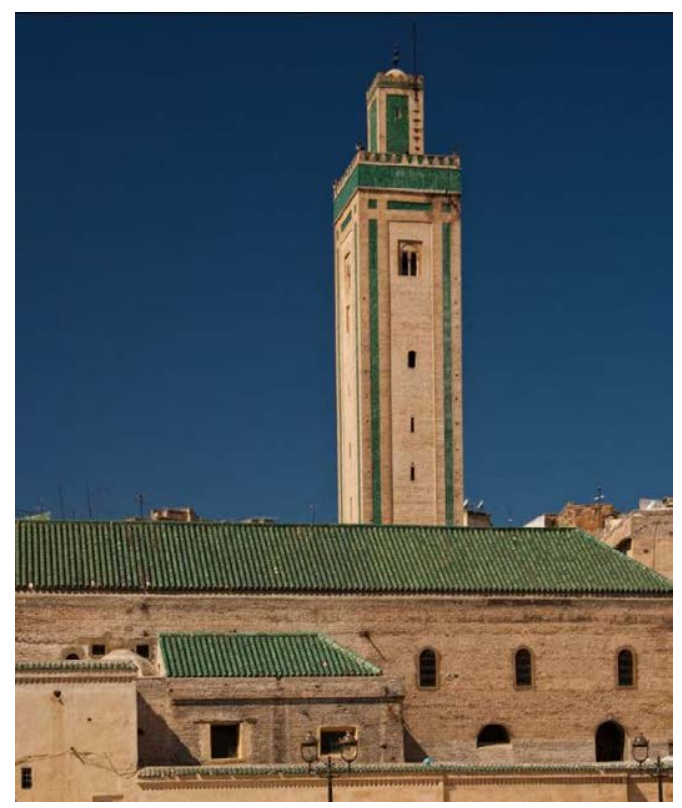

Figure 148: Al Andalus Mosque

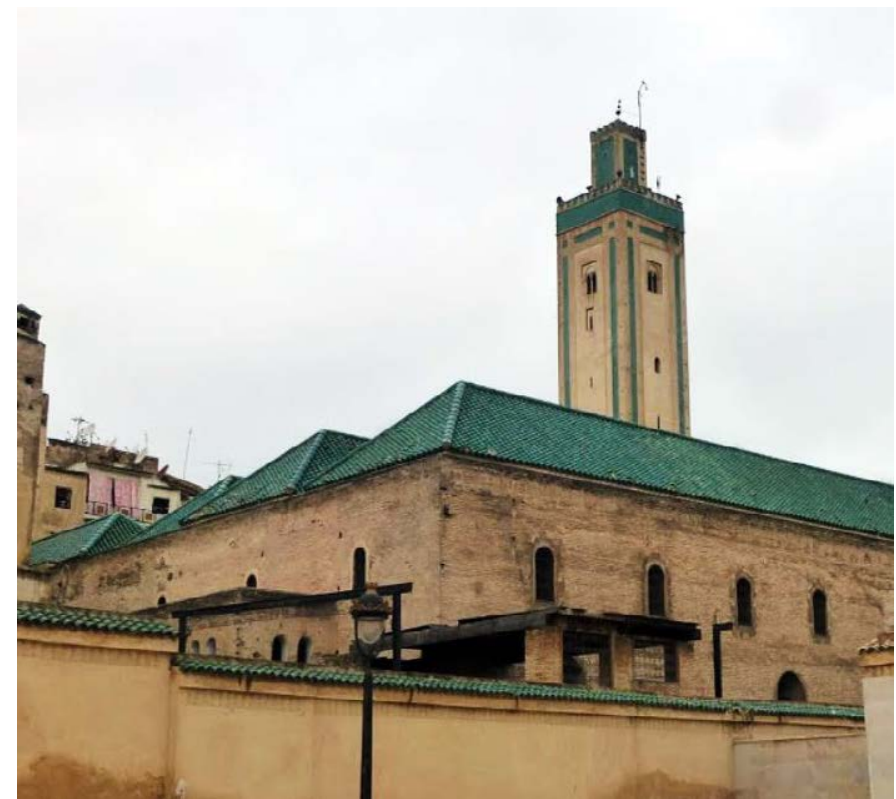

Figure 149: Al Andalus Mosque top view 


\section{b. Qarawiyyin Mosque}

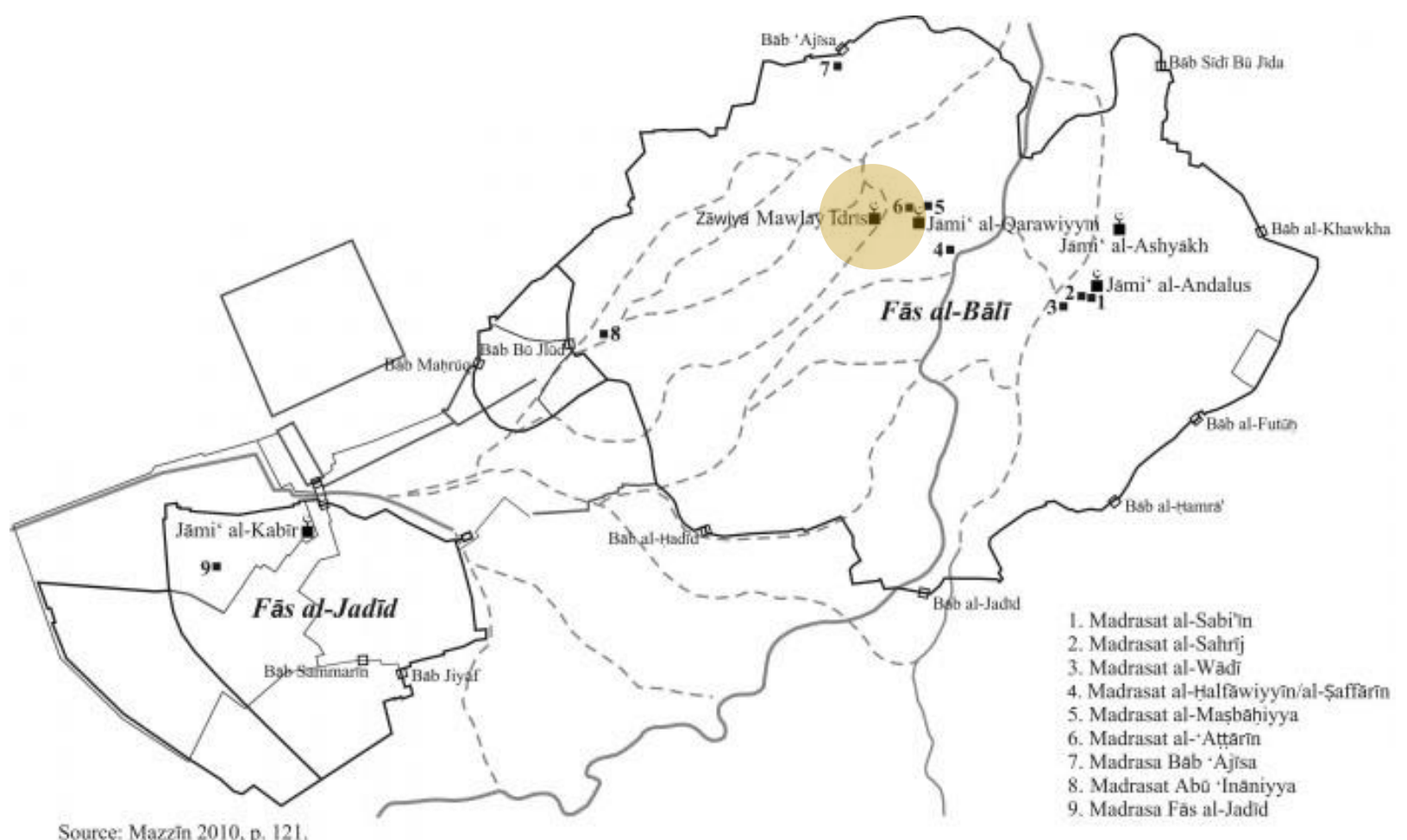

Figure 150: Al Qarawiyyin Quarters in Fes

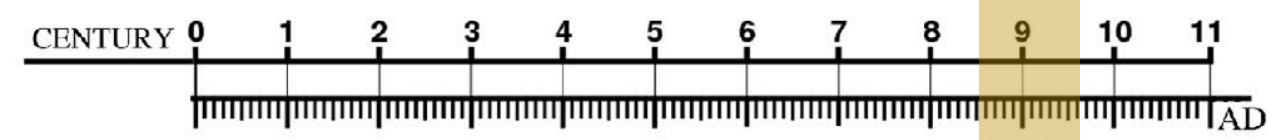

859

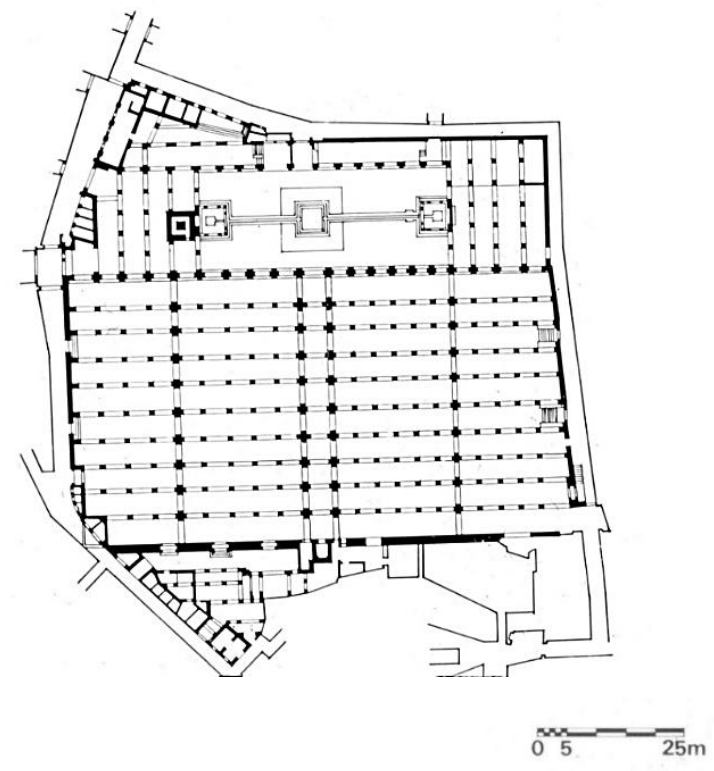

Figure 151: Qarawiyyin Mosque Plan, After Archnet

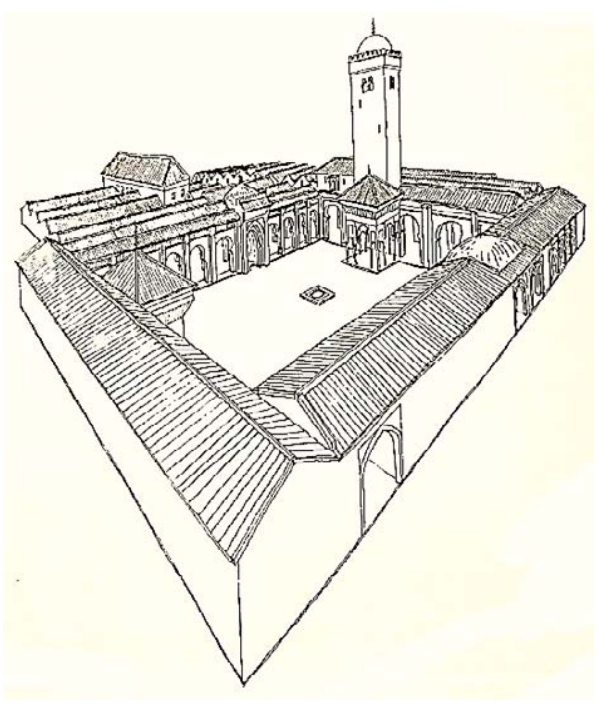

Figure 152: Qarawiyyin Mosque, 859 AD Source: After Creswell 


\subsubsection{Types of Vaults in Fes}

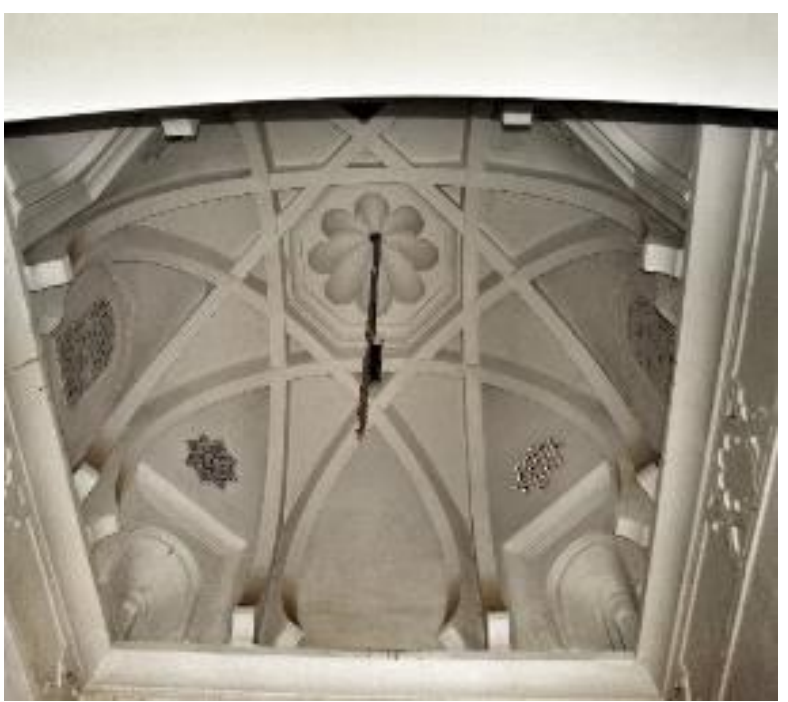

Figure 153: Kashan Vault

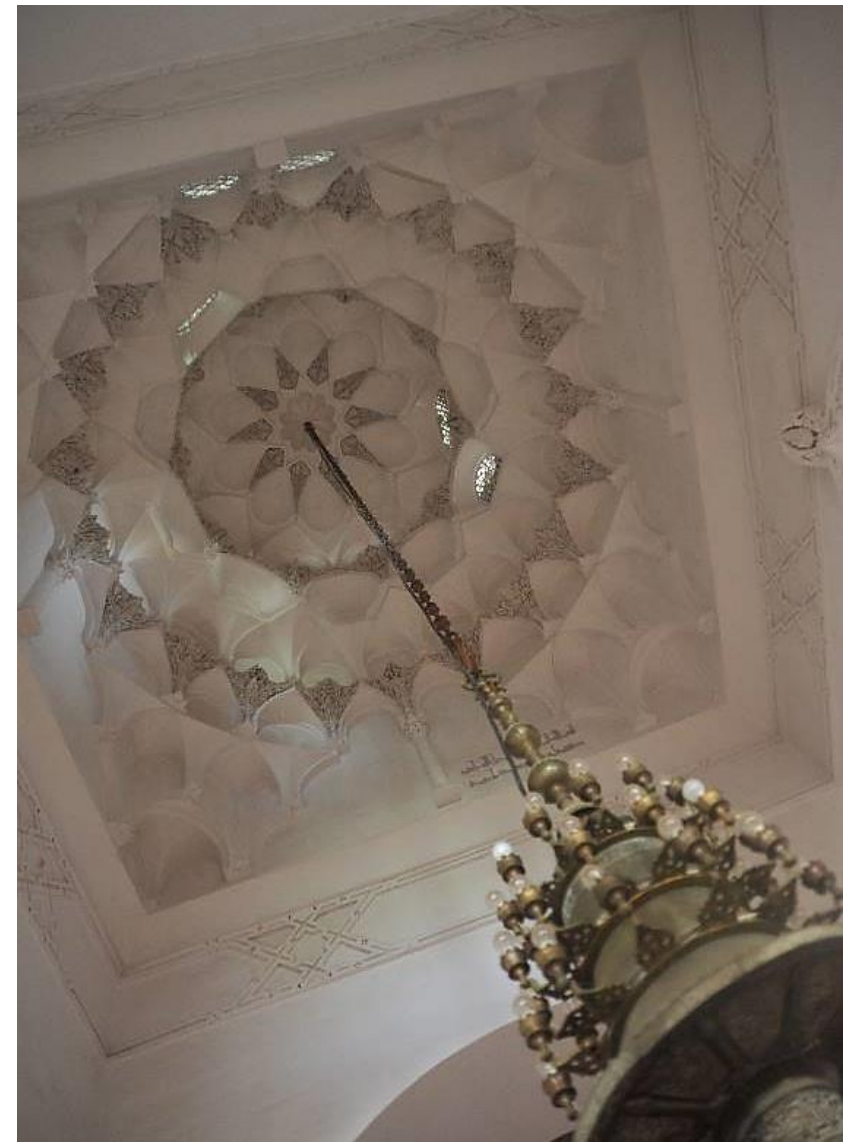

Figure 155: Cress Cross Vault

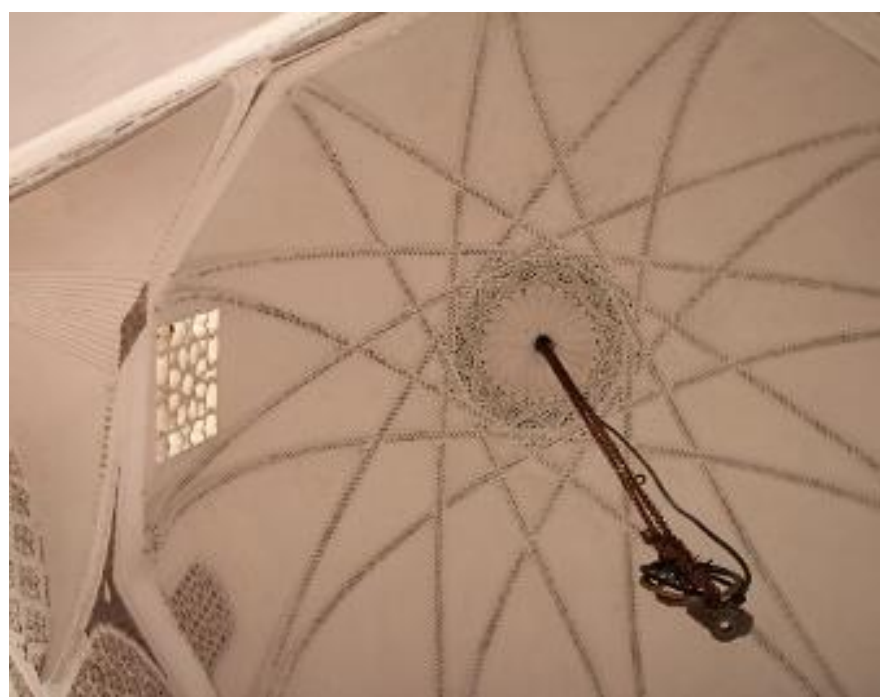

Figure 154: Cross Ribbed Vaults

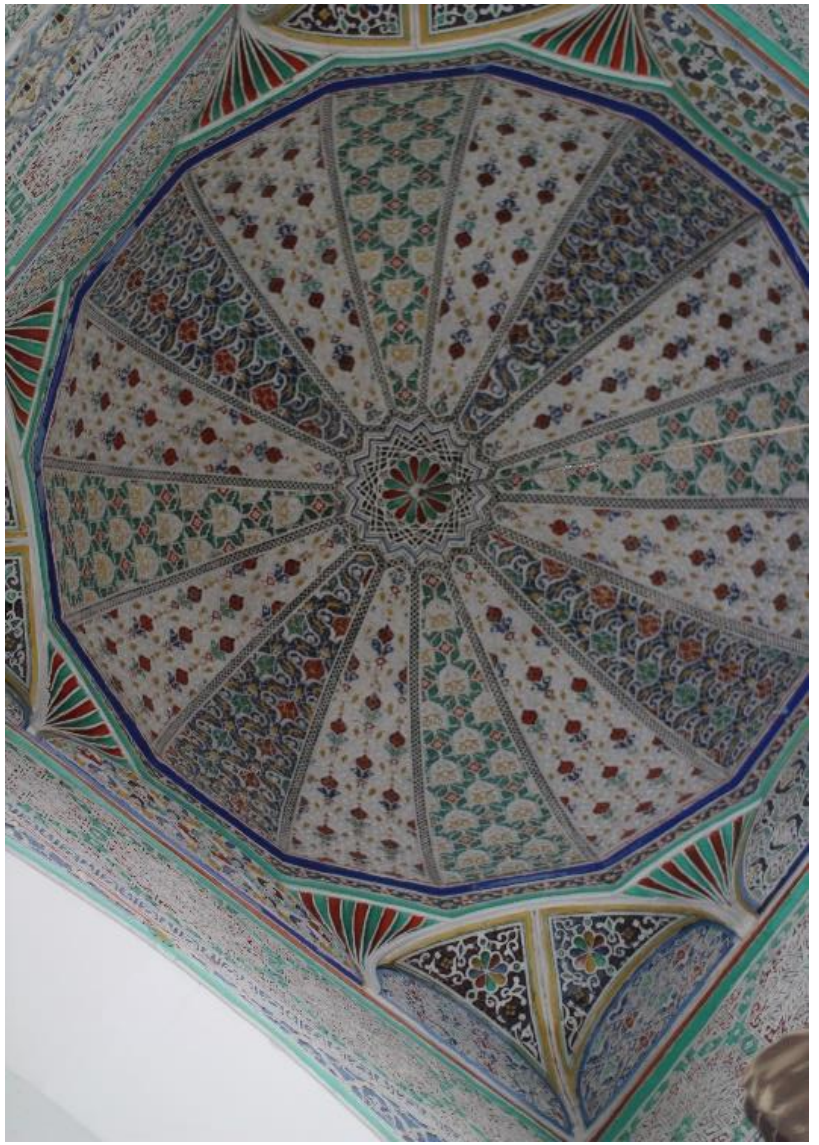

Figure 156: Muqarnad Dome

Source: Photos by the Auther 


\subsection{Aghlabid Introduction: 817- 836 AD}

An Arab commander from Khorasan was assigned to rule the Aghlabid dynasty on behalf of Abbasid Caliphate Haroun Al Rashid. The Dynasty lasted for about a century until their overthrown by the power of Fatimids [Figure 157]. Before the arrival of Ibrahim Ibn Al Aghlabid, Muhallabids ${ }^{33}$ had maintained the Arab rule against the revolution of Berbers in the area. They have ruled continuous succession from 768 until 795 AD. In 800 AD, Aghlabid had ruled after Muhallabids ${ }^{34}$ and became semi-independent rulering much of North Africa [Figure 157]. They imposed their art to the surroundings regions, which had added architectural elements and methodologies to the context of Islamic Architecture [1] [2]. Andrew Petersen had described the Aghlabids period stating in his book: Islamic Architecture Dictionary:

'Tunisian coastal city noted for its ninth-century Aghlabid buildings. Under the Byzantines the city was known as Justinianopolis in honour of Justinian who rebuilt it after the Vandal destruction. In 689 CE it was captured by the Arabs and became one of the principal ports for the Aghlabid conquest of Sicily. In 827 the city was refortified with ramparts and walls built in the Byzantine style. Important Aghlabid buildings within the city include the ribat built or restored by Ziyadat Allah in 821, the BuFatata Mosque built in 840 and the Great Mosque established in 859.' [3]
[1] (Clifford Edmund, 1996)

[2] (Farrar, 2016)

[3] (Petersen, 1996)

The Great Mosque of Kairouan was extended twice. In 836AD, Ziyadat Allah I, tore down most of the Mosque earlier mud bricks

\footnotetext{
${ }^{33}$ Governor of Khorasan and Iraq during Umayyads Caliphates Period.

${ }^{34}$ The previous rulers of Umayyads in Khorasan and Iraq before Abbasids.
} 
and rebuilt it with stone, brick and wood. In the ninth century, a dome was added to the entrance Hall of the Mosque, which is located at the same central axis of Al Mihrab Dome. A Lobbed Dome was added to Al Mihrab during Aghlabids Period in 836 AD [Figure 159] [1].

Historians had different studies and debates in Islamic Domes:

Dr. Colette Apelian mentioned in the Art History and Cultural

Studies Program in his academic article:

'The dome is an architectural element borrowed from Roman and Byzantine architecture. The small windows in the drum of the dome above the Mihrab space let natural light into what was an otherwise dim interior. The drum rests on squinches, small arches decorated with shell over rosette designs similar to examples in Roman, Byzantine, and Umayyad Islamic art. The stone dome is constructed of twenty four ribs that each has a small corbel at their base, so the dome looks like a cut cantaloupe [2].'

Georges Marcais in his book: Muslims Art Published in 1983 had mentioned:

Translated: 'The architecture of Ifriqiya, transmission point domes and disposal had Similarity to Samarra'. [3]

On the other Hand he mentioned in his book: The Architecture of the Mosque:

'The domes appear to have taken their architectural elements of Iraq. Outside, it rises like a dome "with melon slices" on a solid eight concave banks seated on a square pierced solid niche.' [4] (Translated)
[1] (Farrar, 2016)

[2] (Apelian,

\section{[4] (Marcais, xx)}

[Figure 160 ] [Figure 161] 
a. The Great Mosque of Kairouan

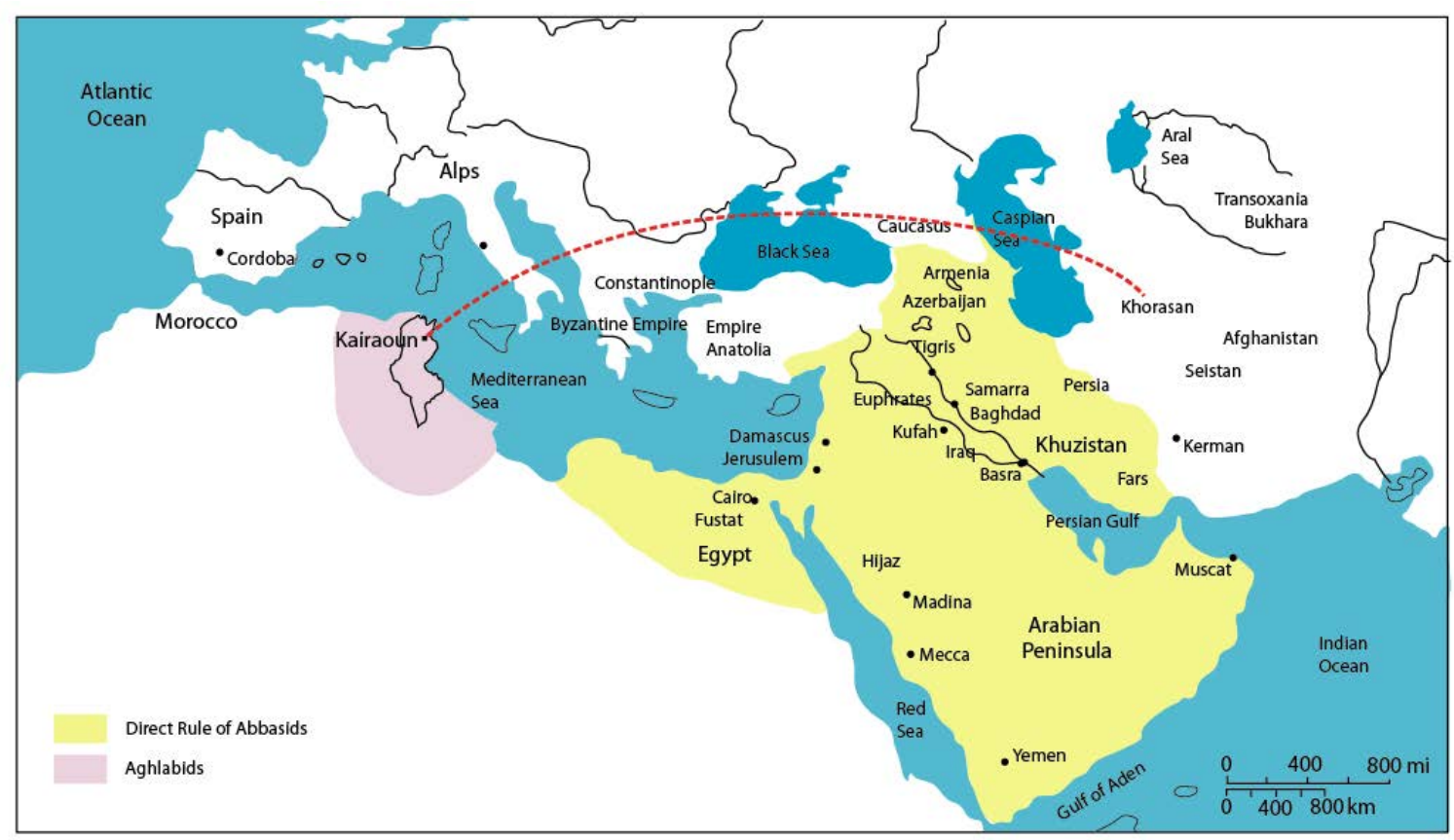

Figure 157: Aghlabids Dynasty during the IX: 817- 836AD

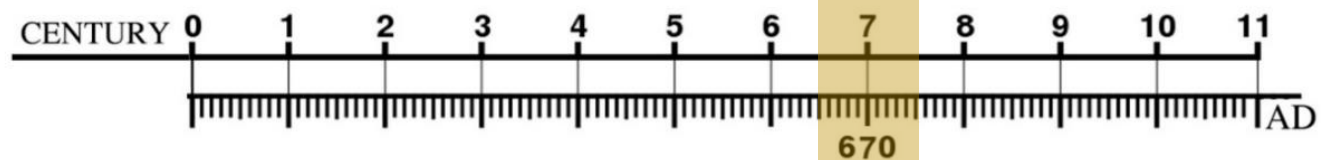

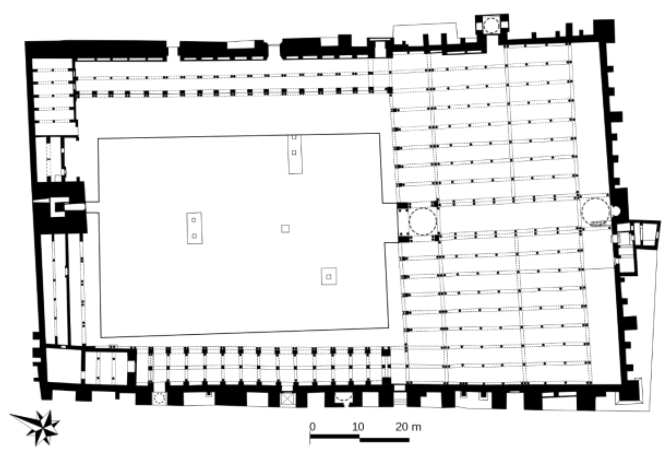

Figure 158: Great Mosque of Kairouan Plan

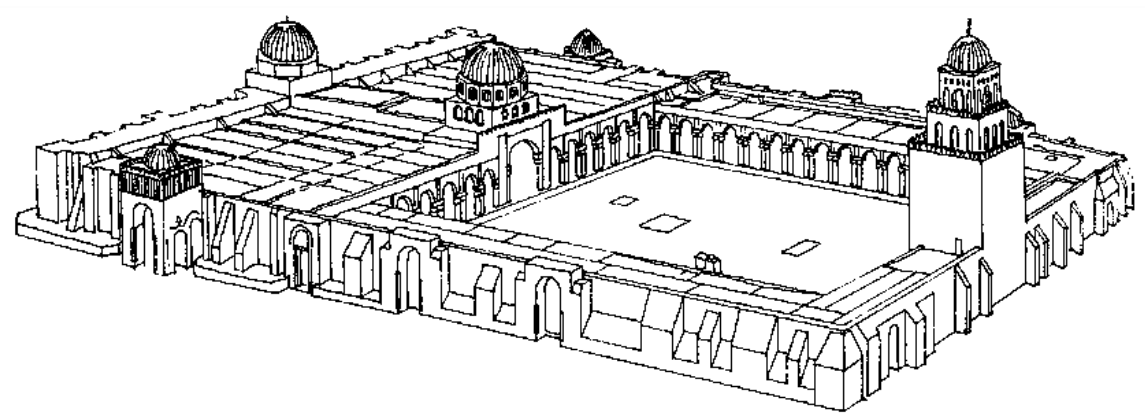

Figure 159: The Great Mosque of Kairouan 
Figure 160: Aghlabids Domes

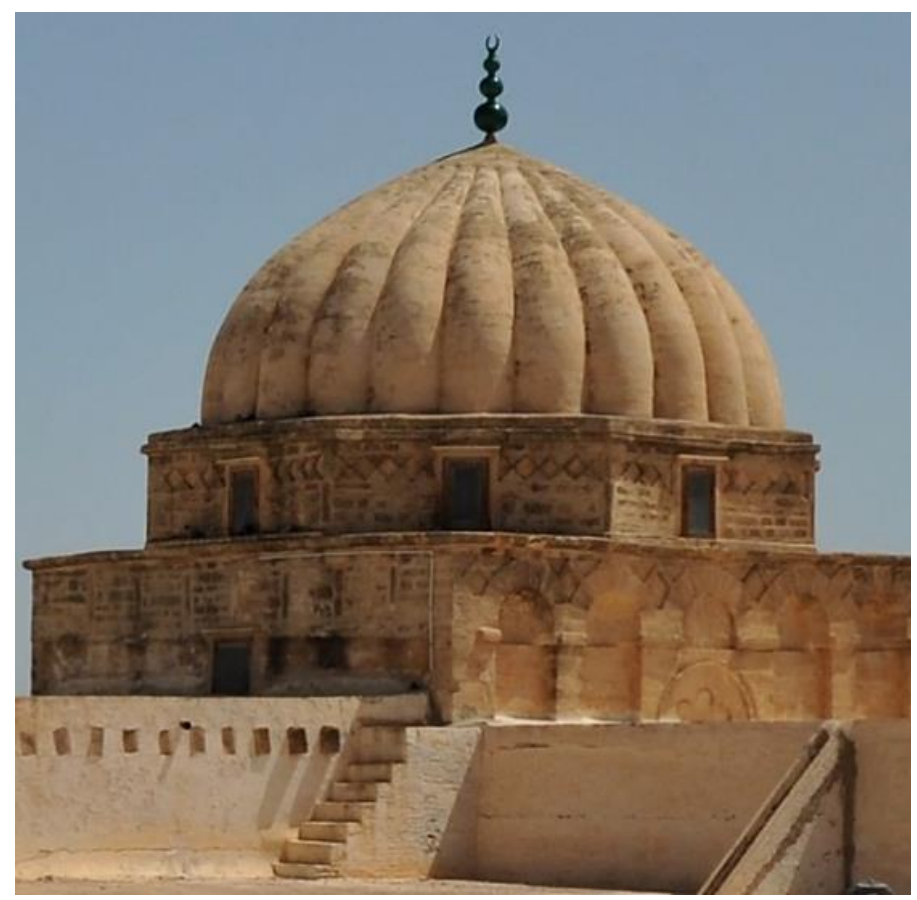

Figure 161: Zrids Dome

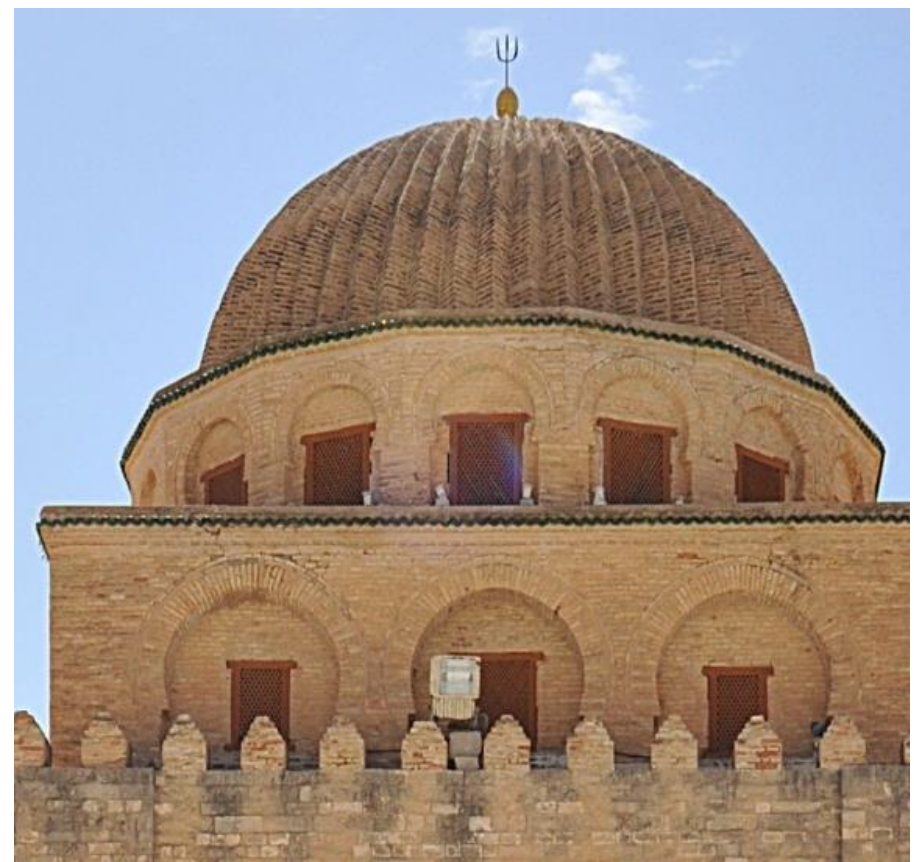

Photos by the Author 
Zaytuna Mosque as well remains one of the most significant examples of Aghlabid and early Hafsid monumental architecture in northern Africa [2]. It famed with its dome that precedes the Mihrab, named as Aghlabid style, while in Sussa the Great Mosque was covered by barrel vaults erected in $850 \mathrm{AD}$. The Mosque contains one of the oldest universities. The mosque was built around $703 A D$ while the University was founded in $737 \mathrm{AD}$ and is considered to be the oldest teaching establishment in Tunis [Figure 163]. This Mosque has great similarities to the Great Mosque of Kairouan rebuilt in $732 \mathrm{AD}$, which was originally erected in 670AD. Zaytuna was built on an old Roman basilica although the original structure no longer exists, but sources point to its construction to Hassan ibn Nu'man. A century after its construction, the mosque was completely rebuilt by Aghlabid Amir, Abu Ibrahim Ahmed. During Abbasid Caliph, Al Musta'in, an inscription at the base of Mihrab indicates that the reconstruction of Zaytuna Mosque was by Fathallah in the night century. The prayer hall is the oldest portion of the surviving mosque, which was constructed under Abu Ibrahim Ahmed, in the night century as well. This hypostyle mosque consist of fifteen aisles wide and eight bays. At the intersection of the central aisle and the transverse bay along the Qibla wall cover with a cupola, immediately before the Mihrab niche. This ornate, four-meter-wide cupola was constructed in 991 AD during the Zirid period [Figure 164] [3] [4] [5] [6]. The location of the dome within the hall also highlights the T-shaped plan famed in Cordoba, which considered a formal traditional design of the medieval period in North Africa and Spain. The cupola over the Mihrab niche was constructed the same time as the Great Mosque of Kairouan, yet the two domes differ in shape; the Mihrab dome at Kairouan rises from an octagonal base and tambour, while the base of the lobbed dome at Zaytuna is square with an octagonal tambour, and its decoration more lavish. At
[2] (Clifford Edmund, 1996)

[3] (Michell, 1978)

P. 221

[4] Hillenbrand, Robert. 1994.

[5] (Mami, 2011)

[6] (Achour, 1991) 
the northern end of the central aisle is a second cupola, which marks the principal entrance to the prayer hall. [1] [2]

\section{c. The Great Mosque of Sussa}

Sussa Mosque comprises a prayer hall preceded by a courtyard. The courtyard is wider than it is deep and has porticoes lining three sides. The fourth portico at the front of the prayer hall is an addition which probably dates from the AH 5th century (AD 11th). As the Sousse Mosque has no minaret, the call to prayer was proclaimed from the top of the northeast corner tower, which has a domed kiosk and is accessible by a staircase giving onto the courtyard. The prayer hall is quadrilateral in shape (59 $\mathrm{m} \times 51 \mathrm{~m}$ ) and is divided into 13 naves and 6 bays. The central nave is wider than the others and is crowned with two domes. The dome of the Mihrab is semi-spherical and rests on a tambour with eight concave facets. The massive stone base is decorated with denticles. Internally, the dome rests on angled squinches. The prayer hall is covered with barrel vaults reinforced by semi-circular beam-arches. The vaults are supported by stone cruciform pillars. The Mihrab dates to the Zirid period, judging by the decoration of the semi-cylindrical niches and the inscription rings with their flower y Kufic characters [Figure 166-169] [3] [4] [5].
[1] Blair, Sheila S. And Jonathan Bloom, 1994). P.253254.

[2] (Clifford Edmund, 1996)

P. 31-32, 35-36, 45-47.

[3] (Creswell, K. A. C, 1989). P. $246-51$

[4] Marcais, 1954)

P.23-24.

[5] (Marcais, 1954)

P. 195 


\section{b. Zaytuna Mosque}

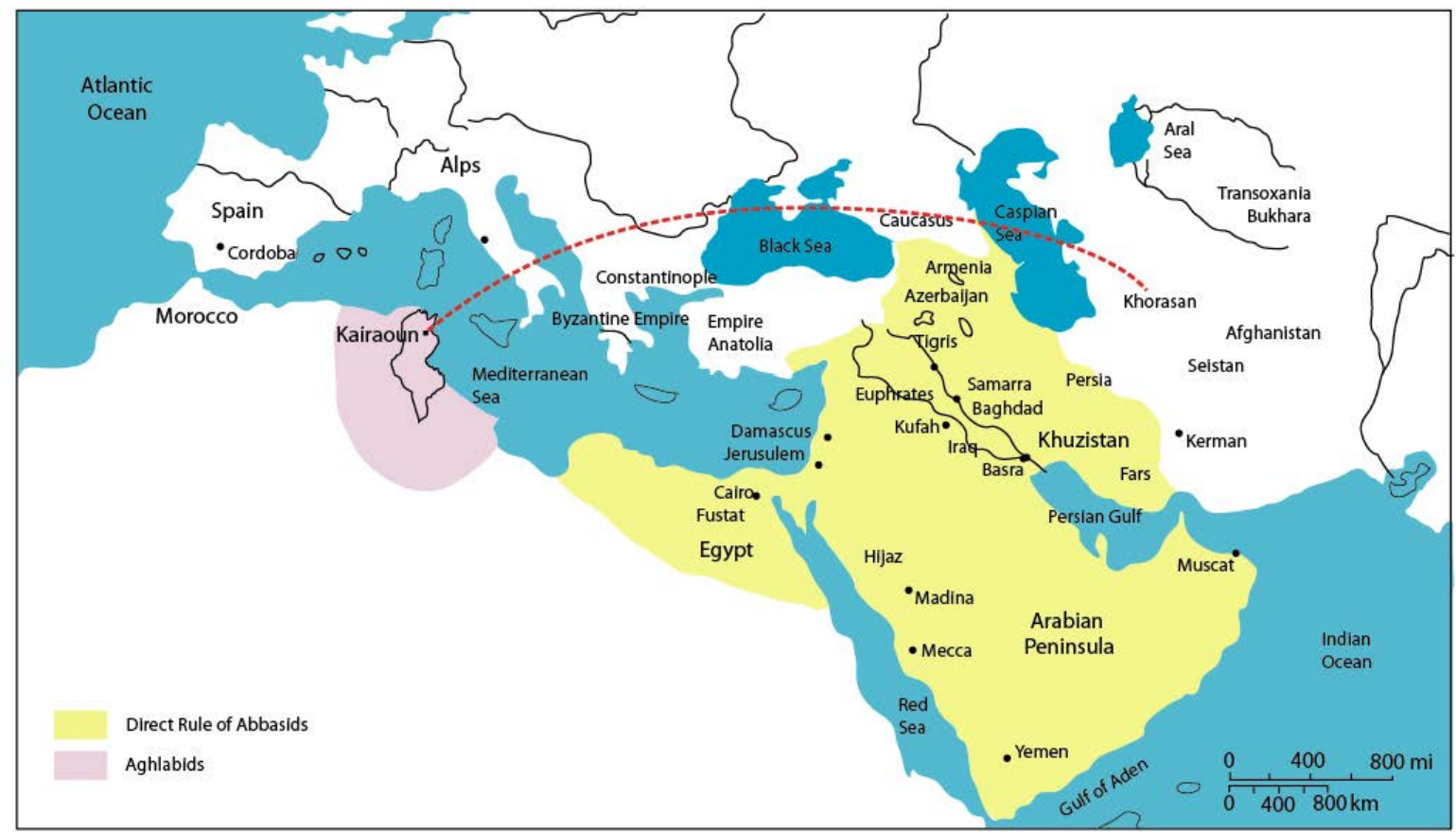

Figure 162: Zaytuna Mosque Location, Tunis

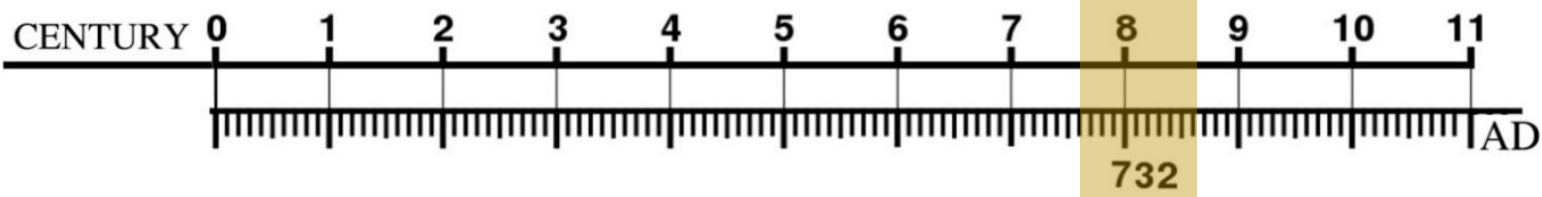

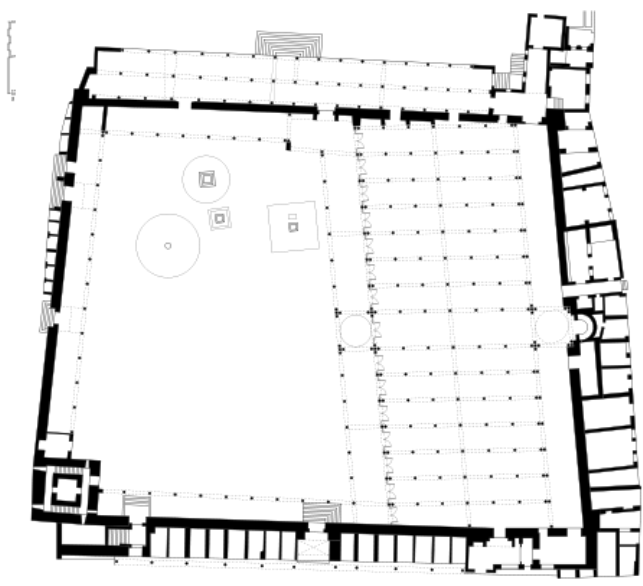

Figure 163: Zaytuna Mosque Plan, Tunis

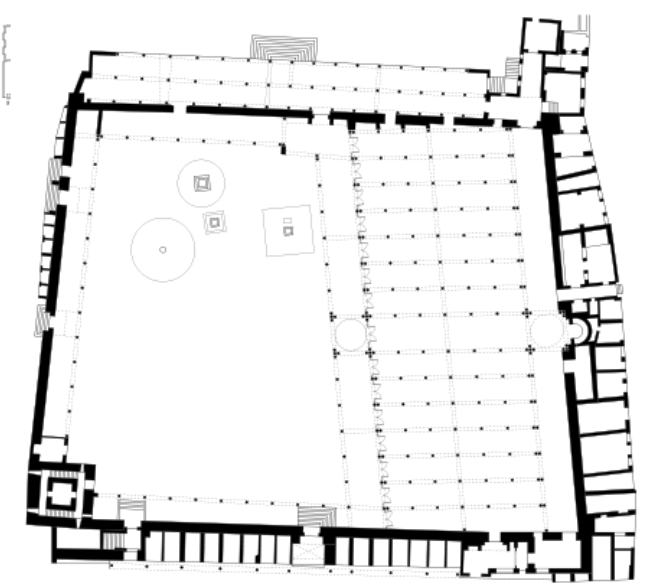

Figure 164: Zaytuna Mosque 


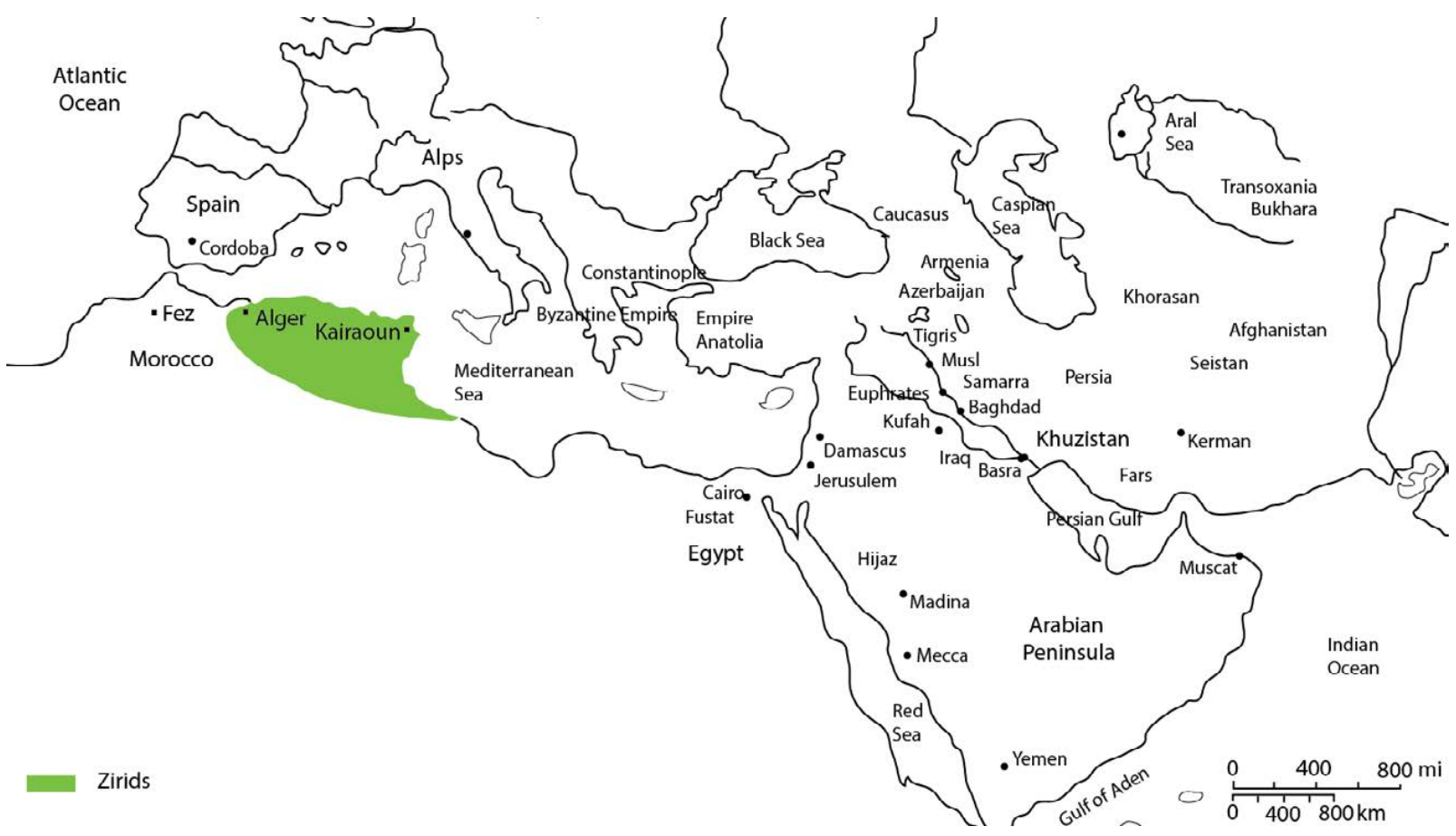

Figure 165: Susa, Location

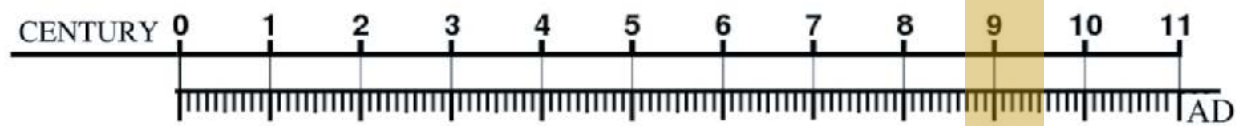

859

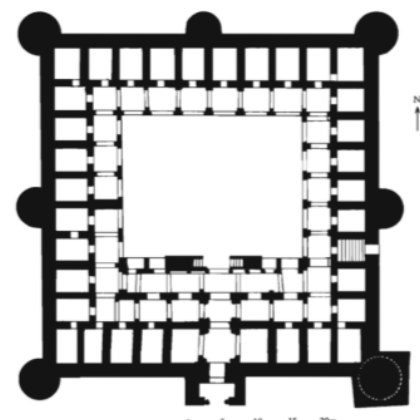

Figure 166: Susa Plan, 859AD

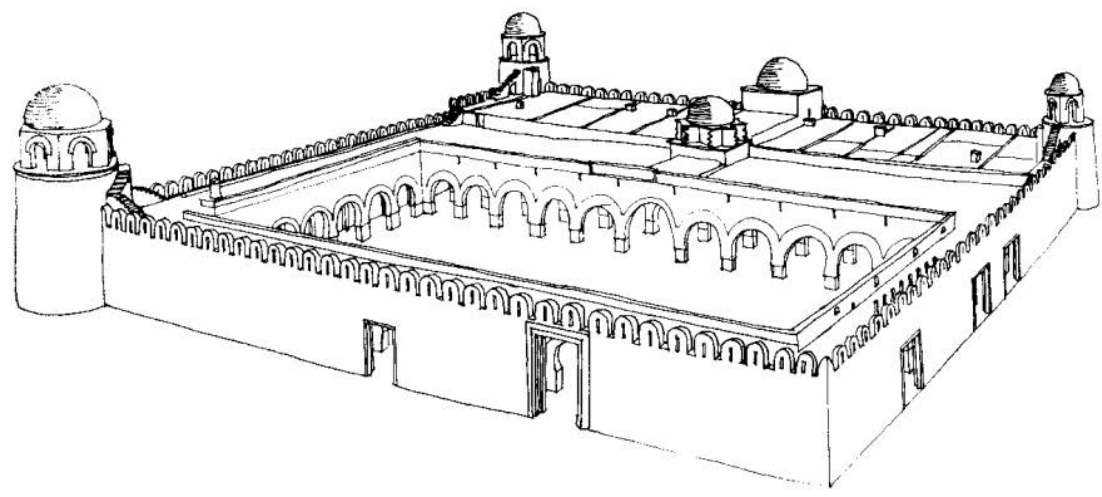

Figure 167: Susa, 859 and extended in the Zirid era AD 988

Source: Creswell 


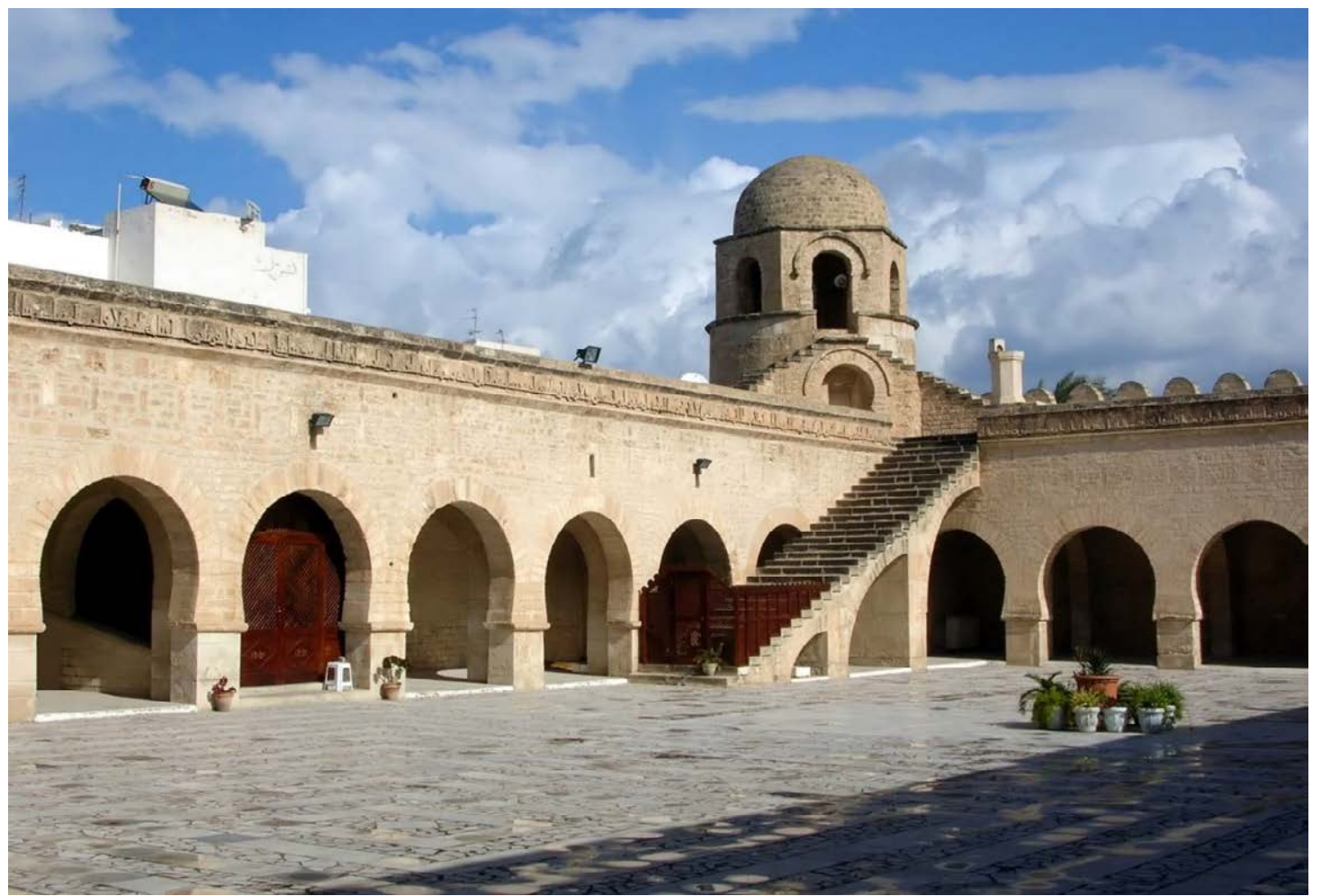

Figure 168: Susa, 859 and extended in the Zirid era AD 988

\section{Source: Wikipedia}

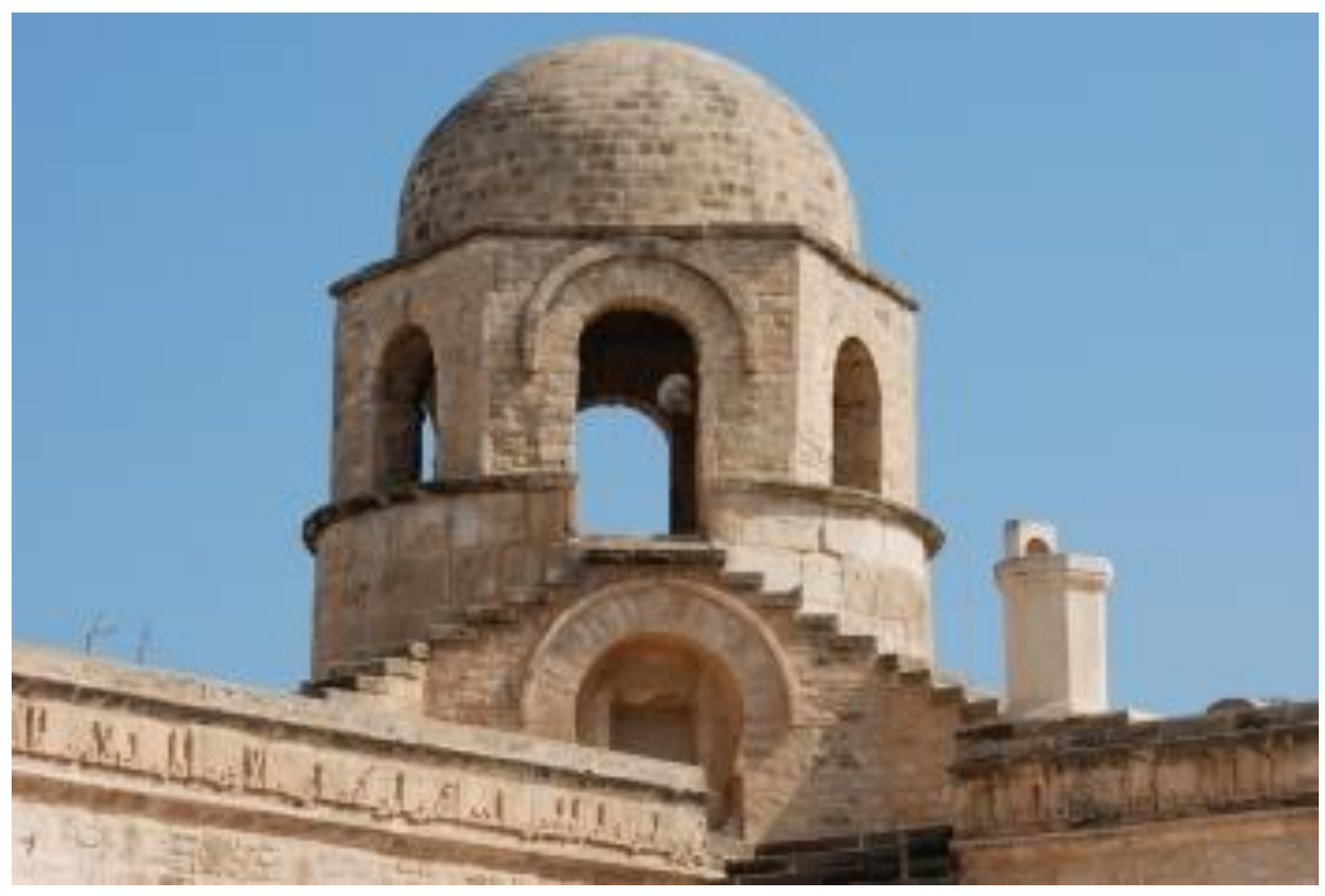

Figure 169: Susa, 859 and extended in the Zirid era AD 988

Source: Qantara 


\subsubsection{Type of Vaults in Tunis}

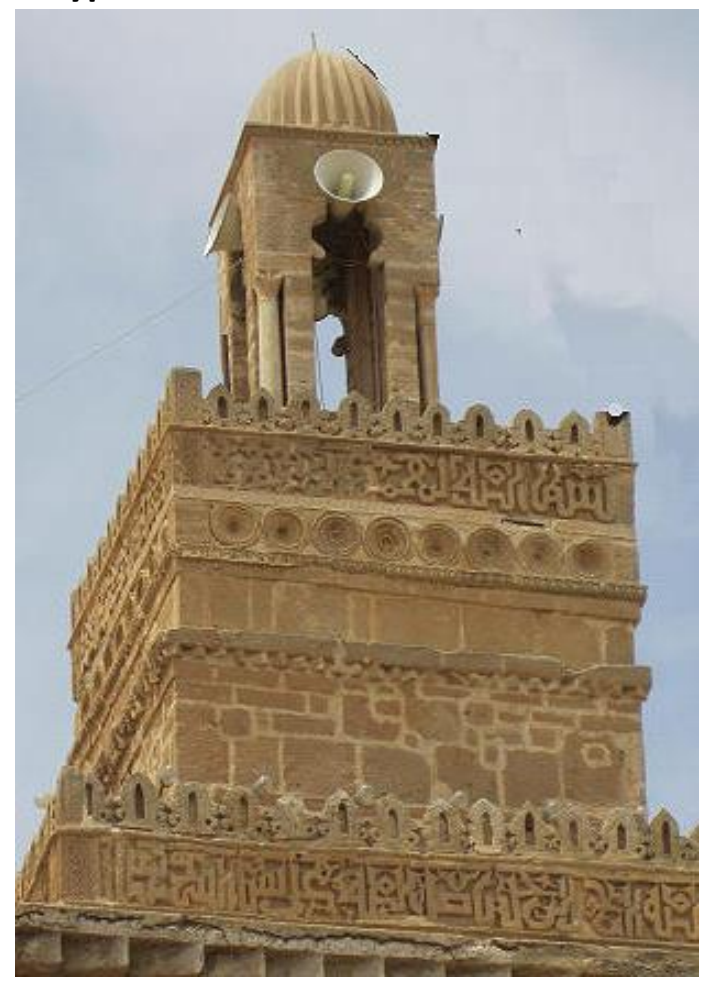

Figure 170: Great Mosque at Sfax, 849AD

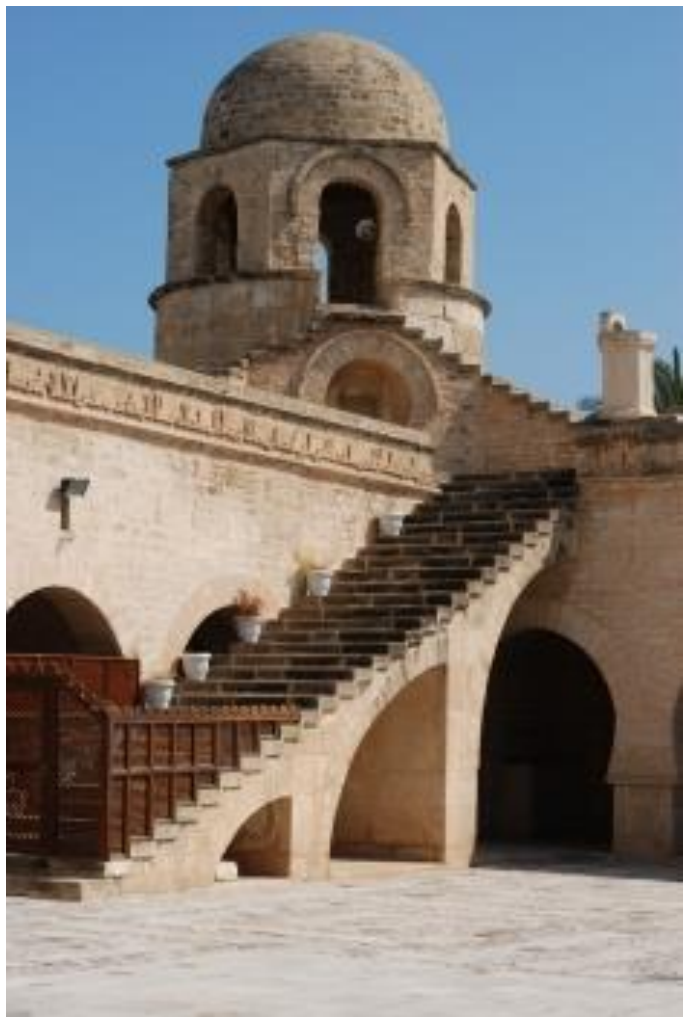

Figure 172: Great Mosque of Susa tower Dome, 851AD

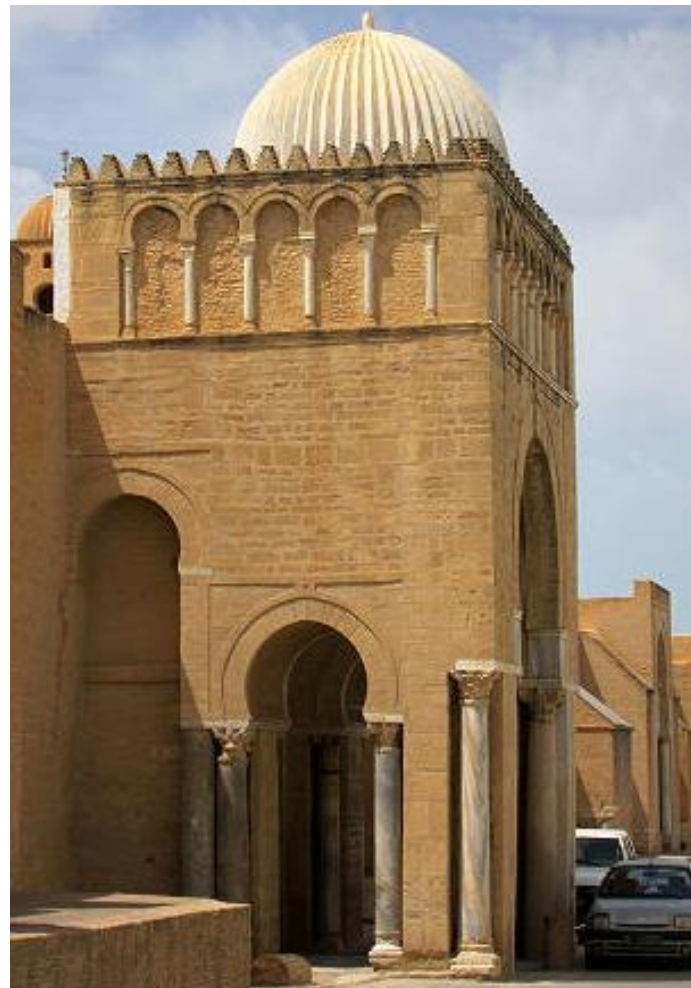

Figure 171: Great Mosque of Kairouan

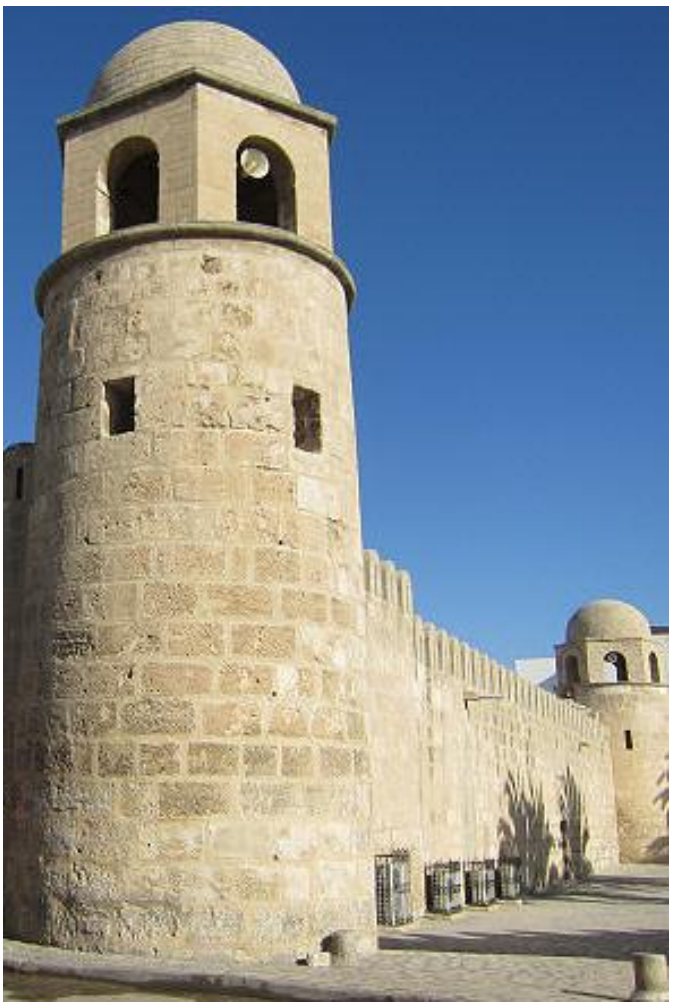

Figure 173: Great Mosque of Susa Tower Dome, 851AD 


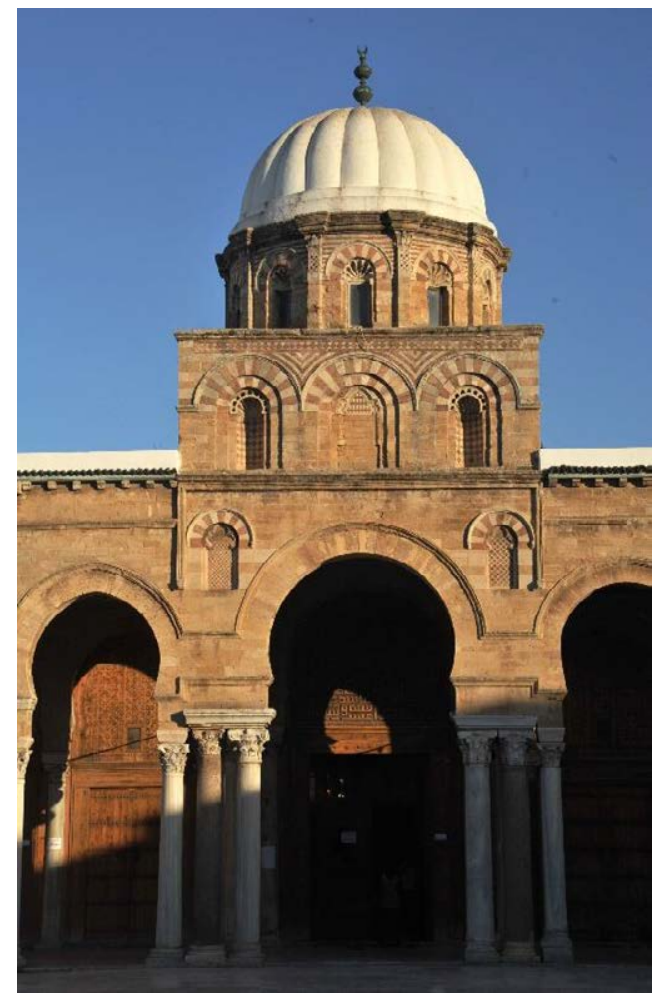

Figure 174: Zaytuna Mosque Chamber Dome

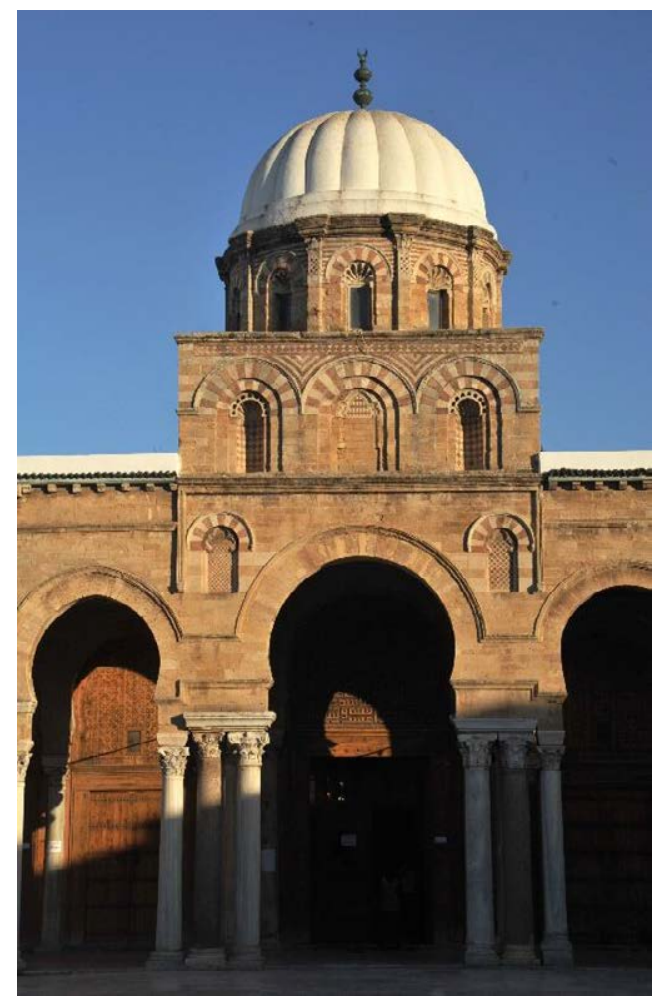

Figure 176: Great Mosque of Kairouan

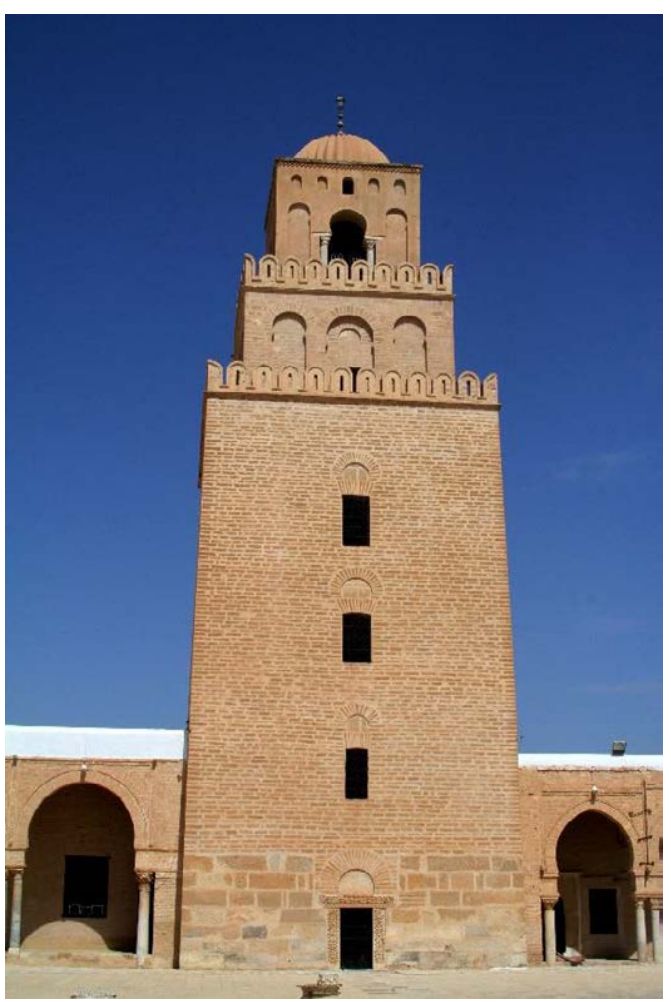

Figure 175: Great Mosque of Kairouan Minaret Dome

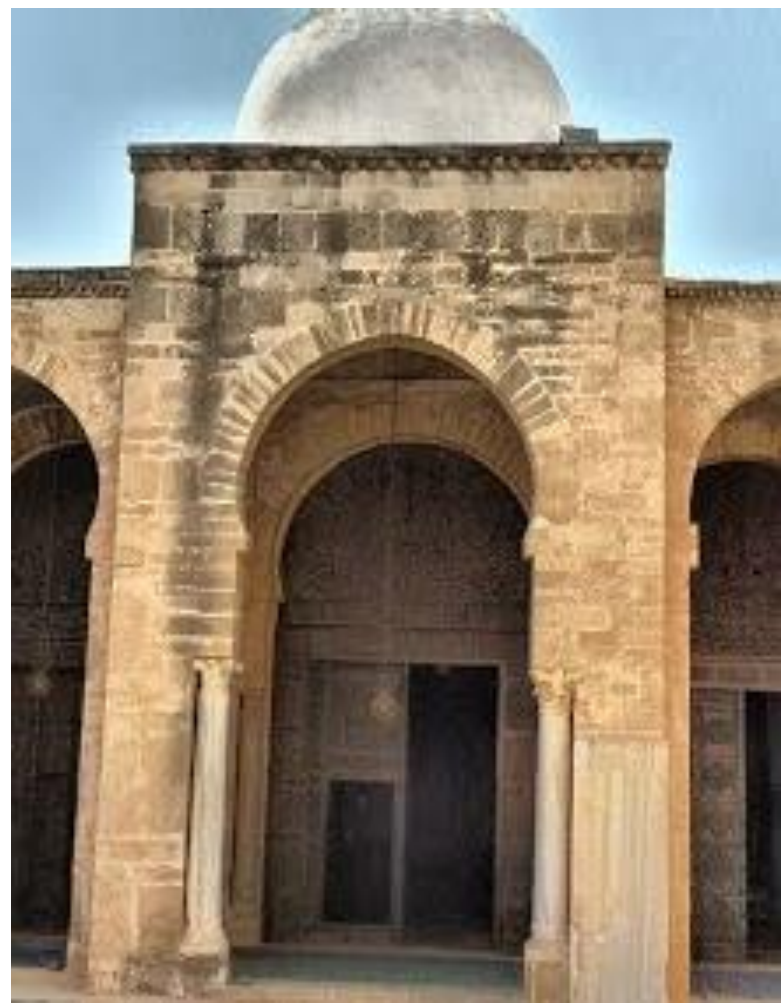

Figure 177: Great Mosque of Sfax

Wikipedia 


\subsection{Rustamid Vaults: 776-909 AD}

North Algeria: Persian origin.

Rustamids were Persian origin, their Dynasty established in bound [1] (Britannica with Berbers uprising against Umayyads in 740 AD, which resulted into the potion of Maghreb and the clearness of Umayyad control in Encyclopaedia, 2008) the region. Rustamid Dynasty had developed by followers of Ibadiyah branch of Kharijism. Badism is a branch of Islam that is neither Sunni nor Shiite. It existed mainly in Oman, East Africa, Mzab valley of Algeria, Nafus mountains of Libya, and the island of Jerba in Tunisia [Figure 178]. It was initiated in the seventh century by $A /$ Ibadi Kharijism, imams of Berber who ruled central Maghreb for a century and a half from Tiaret ${ }^{35}$, which is the capital of the dynasty until the Ismaili Fatimid Caliphate destroyed them. The Berber revolutionary achieved an astounding military success against the Arab army. The Kharijism found support among the Berber tribes. By 742AD, they took control of whole Algeria and were threatening Kairouan. In the meantime the Ibadiyah, who constituted the moderate branch of the Kharijism took control of Tripolitania ${ }^{36}$ by converting the Berber tribes living there; especially the Hawwara. The state was governed by imams descended from Abdul Al Rahman ibn Rustam, Persian origin who founded the state [1] [2].

\footnotetext{
${ }^{35}$ Algeria

${ }^{36}$ Westren Libya
} 


\section{a. Atique Mosque}

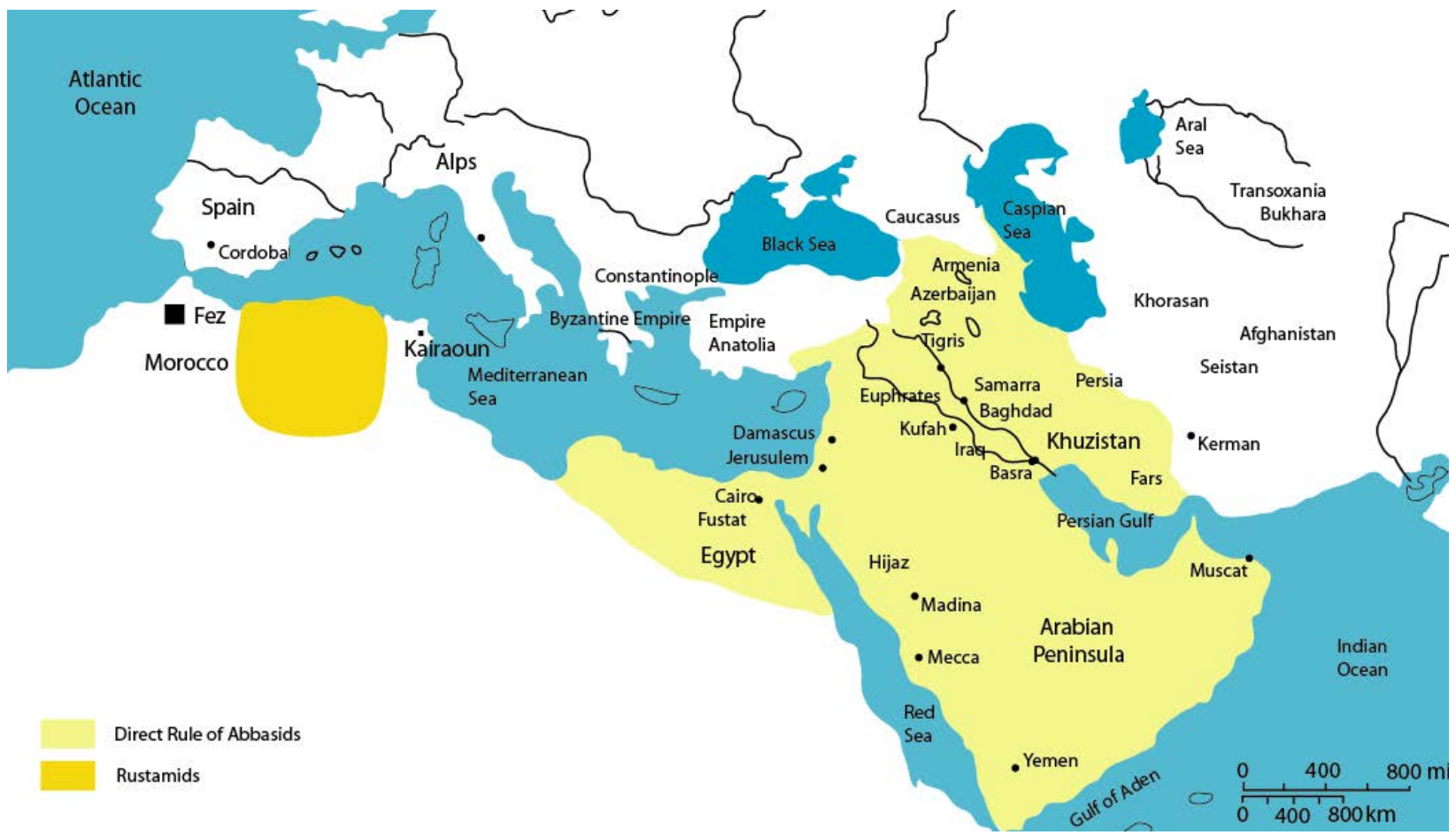

Figure 178: Rustamid Dynasty: 776-909 AD

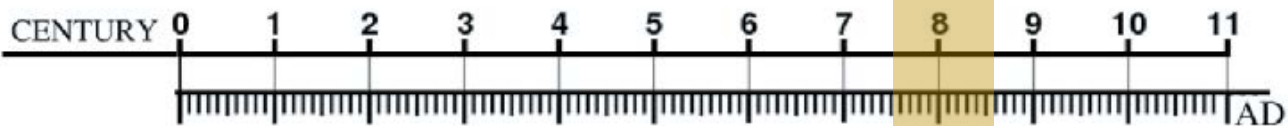

776

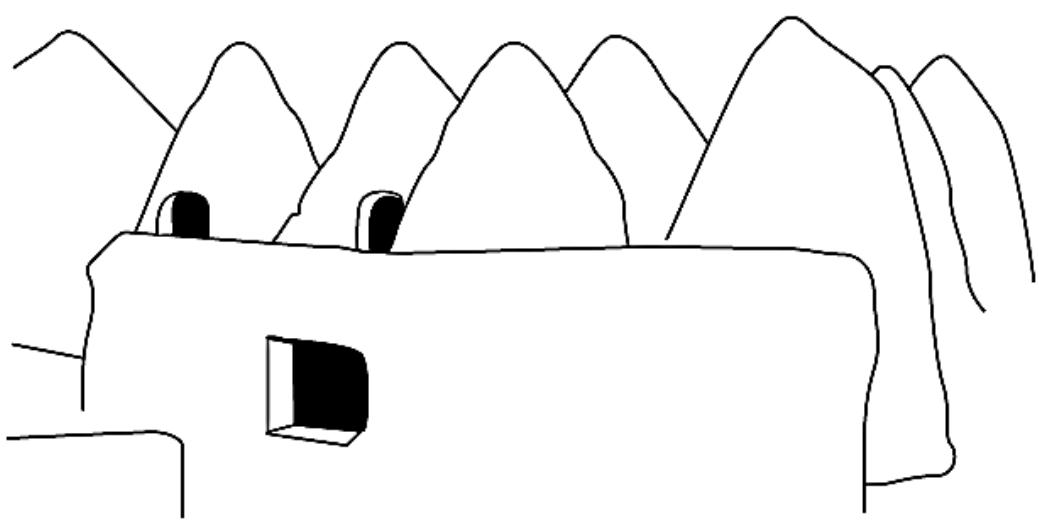

Figure 179: Atique Mosque or Al Kabir Mosque, Libya 


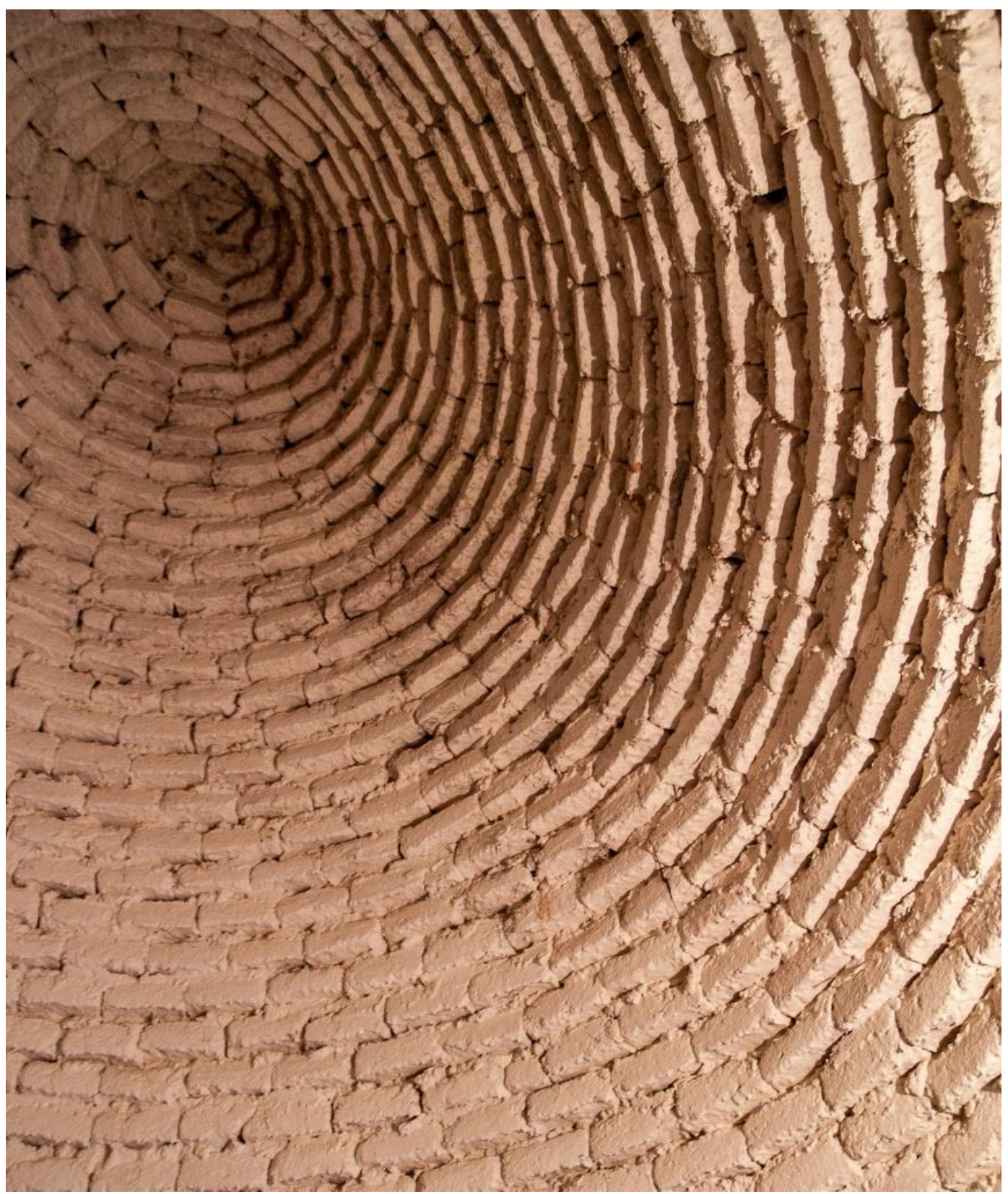

Figure 180: Brick Method in Libya, Atique Mosque 
Surt in Libya located in the crossroads of the caravan routes used by the pilgrims of Al Andalus and the Maghreb to travel from West to East towards Egypt then the holy cities of Mecca and Madinah. On the other hand, The Ajdabiya in Libya, which was conquered in 643 AD by Arab armies under Amr ibn Al As had converted to Ibadism, and also other parts of the Maghreb. Ajdabiya City was also an active caravan centre connection between Maghreb to Egypt routes from southern Sahara to the Mediterranean lands. The Arab geographers at the time described Ajdabiya as a city built from sundried clay bricks. The Atiq Mosque which is also called the Great Mosque or Al Kabir mosque in Arabic is located in an oasis village of Awjila in the Sahara desert of Eastern Libya [Figure 179]. It was built in the XII century and considered the oldest Mosque in the region. It has conical domes made of mudbrick and limestone. In Tanzania there was The Great Mosque of Kilwa, a congregational mosque on the island of Kilwa Kisiwani. It was likely founded in the tenth century, but the two major stages of construction date to the eleventh or twelfth and thirteenth century [Figure 181]. It is one of the earliest surviving mosques on the East African coast. The smaller northern prayer hall dates to the first phase of construction. It contained a total of 16 bays, supported by nine pillars, originally carved from coral but later replaced by timber. The structure, which was entirely roofed, was perhaps one of the first mosques to have been built without a courtyard [Figure 183] [1].

[1] Archnet Group 


\section{b. The Great Mosque of Kilwa}

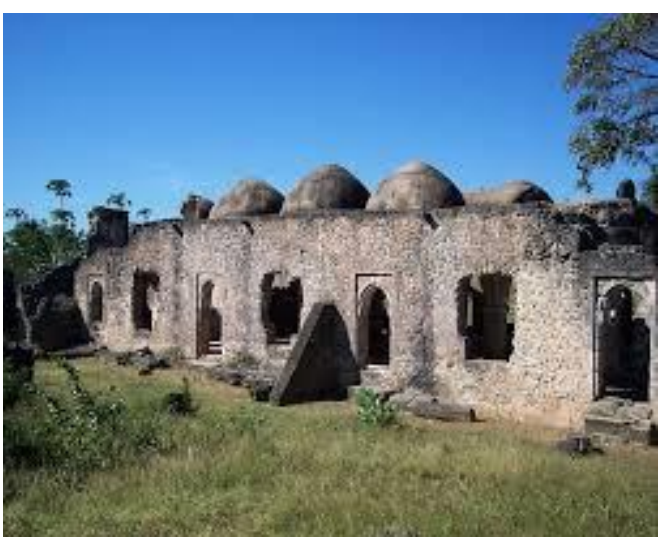

Figure 181: The Great Mosque of Kilwa

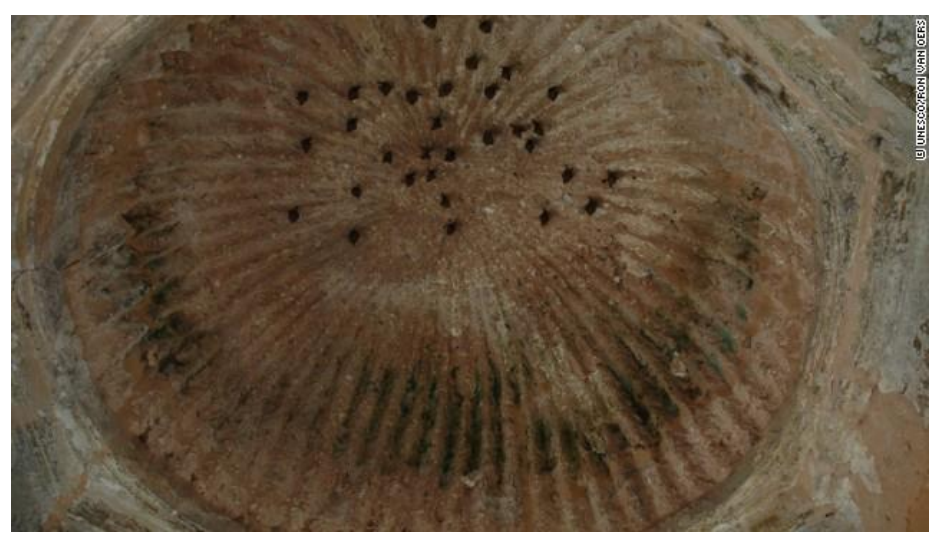

Figure 182: The Great Mosque of Kilwa Dome

Photoes By Teo Kermeliotis, for CNN
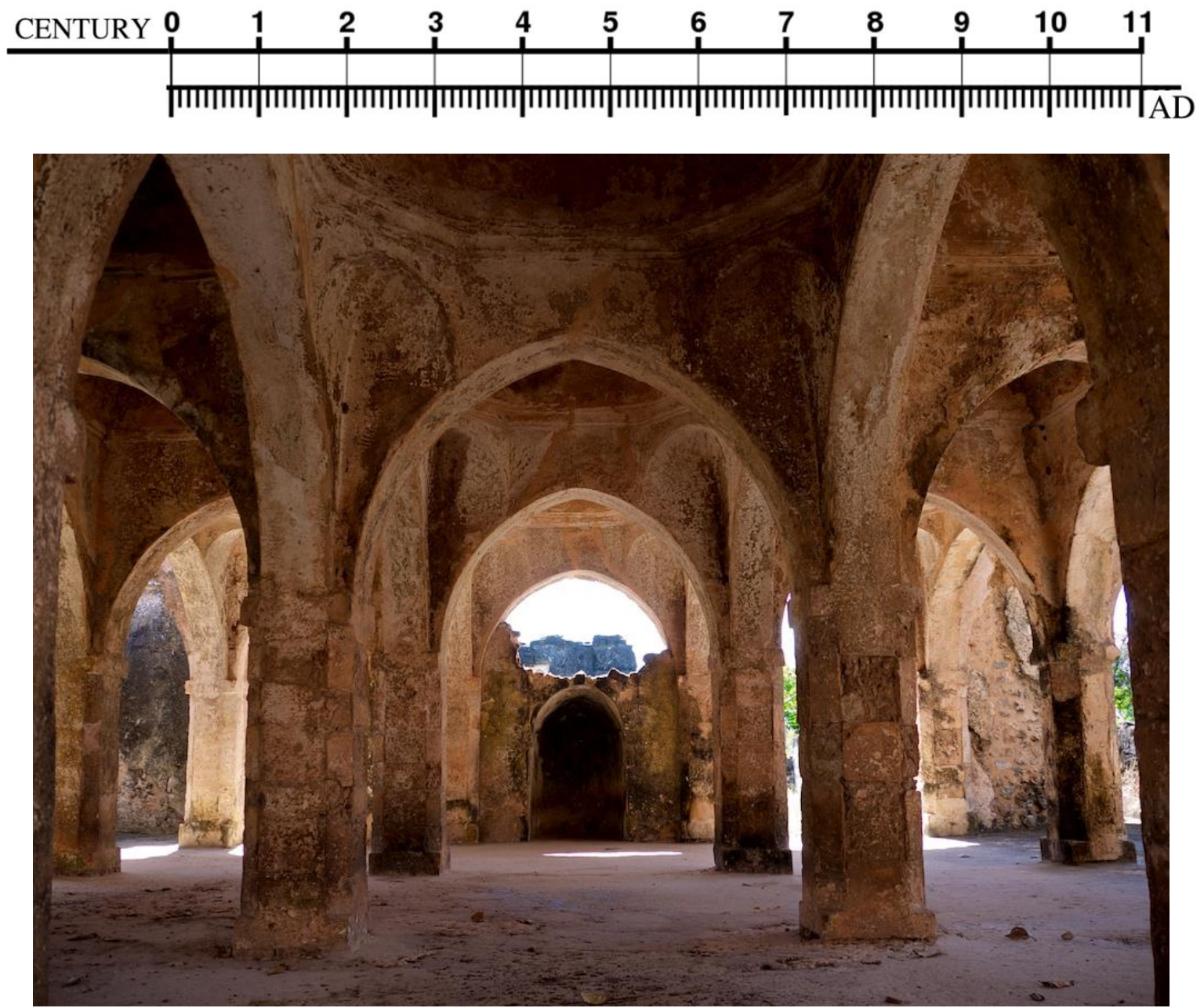

Figure 183: The Great Mosque of Kilwa in Tanzania 


\subsection{Tulunid Introduction: 868-906 AD}

The Tulunid dynasty of Turkic origin were the first independent dynasty to rule Islamic Egypt, as well as parts of Libya and Anatolia [Figure 184]. They remained independent from 868AD when they broke from the Abbasid dynasty in 905AD as the Abbasids restored the Tulunid to their control again later. The mosque of ibn Tulun was constructed in 876AD for Ahmad Ibn Tulun, the son of a Turkish slave of Mongol origins owned by the Abbasid Caliph Al Ma'mun. Ahmad was sent to Egypt in 868AD as governor of Fustat ${ }^{37}$, but within two years he had been made governor of the whole country. The Mosque of Ibn Tulun was the third congregational ${ }^{38}$ mosque to be built in Cairo [Figure 186]. The Building was constructed with a similar influence of the Great Mosque of Samarra as its minaret resembles the Spiral Minarets of Samarra Mosques that was completed in 879AD. The ablution fountain and dome were built on the site of the fountain but destroyed by a fire in 986AD the dome was carried on gilded marble columns. A tunnel vault carry the bridge between the roof of the mosque and the minaret springs [Figure 190]. This influence is accounted by the resettlement of the Andalusian Muslim refugees in Egypt of who were driven out from Andalusia by the Christian reconquest during late 1212- 1260 AD. Andalusian influence can be seen in the horseshoe arches of the minaret windows, which were brought to Egypt. The relatively deep carving and stylized treatment of the motifs are significance of the Eastern Abbasid tradition, particularly stucco and woodwork in decorations from Samarra in Iraq [1] [2] [3] [4] [5].
[1] (Behrens-Abouseif, 1989)

[2] (Britannica

Encyclopaedia, 2005)

[3] (Swelim, 1994)

[4] (Williams, 2002)

P. $46-49$

[5] (Wahhab, 1940)

\footnotetext{
37 Old Cairo

${ }^{38}$ The main mosque of a town, city or village.
} 
a. Ibn Tulun Mosque

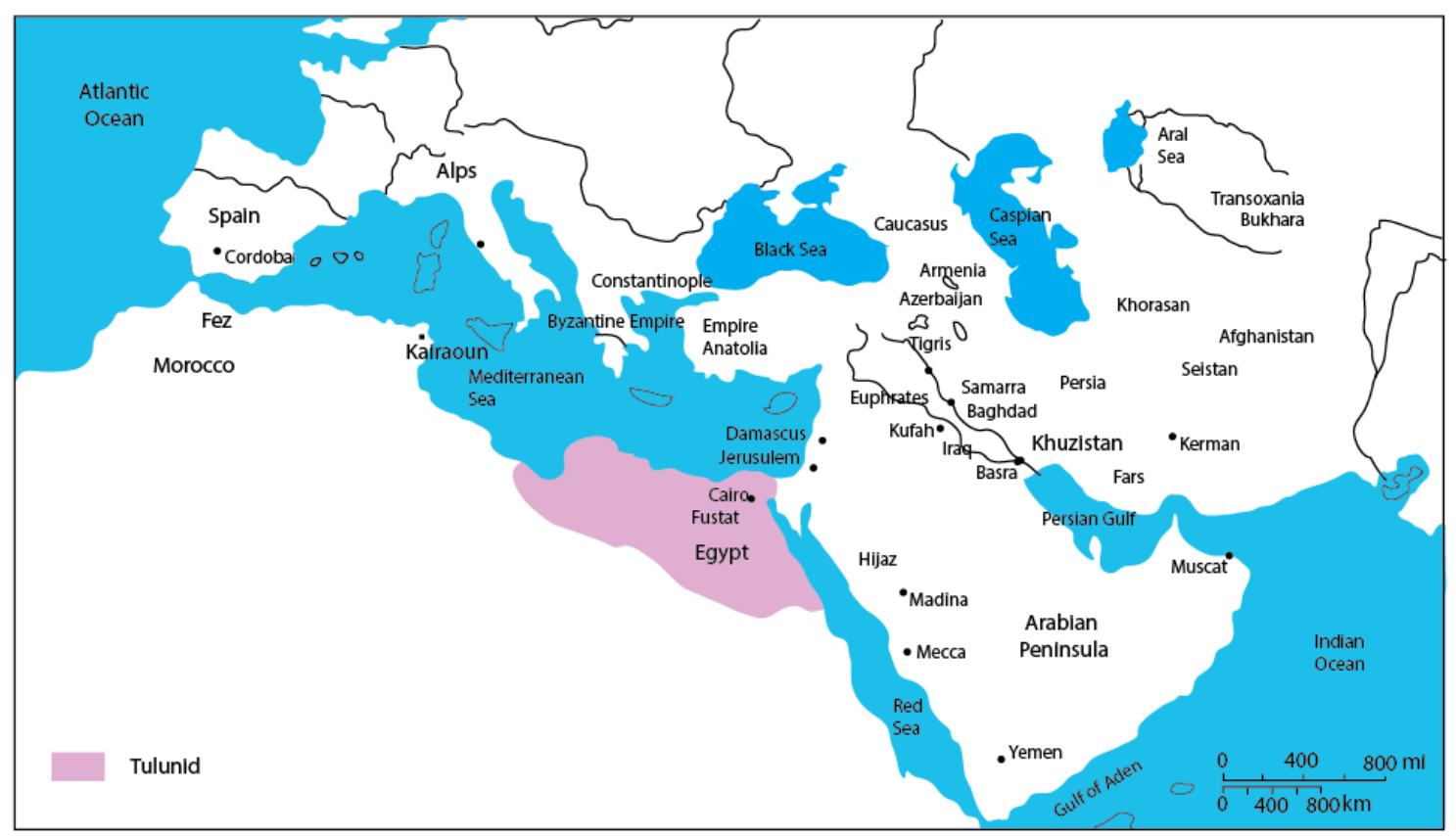

Figure 184: Tulunid Dynasty, 868-906 AD

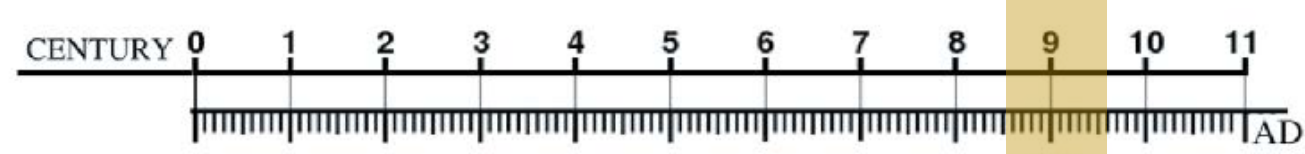

\section{6}

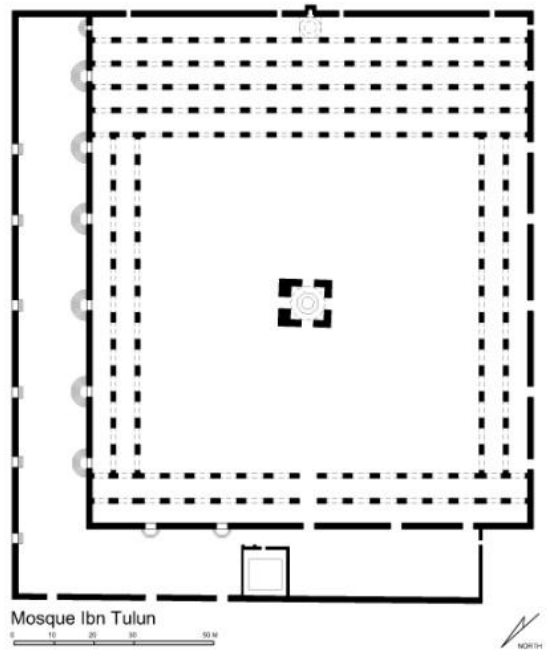

Figure 185: Ibn Tulun, 876 AD

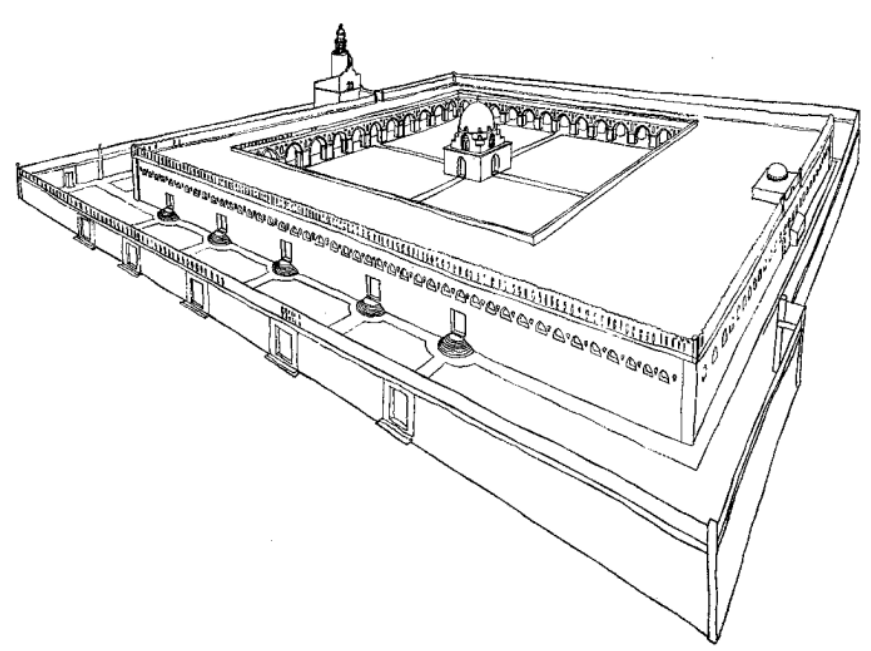

Figure 186: Ibn Tulun, 876 AD 


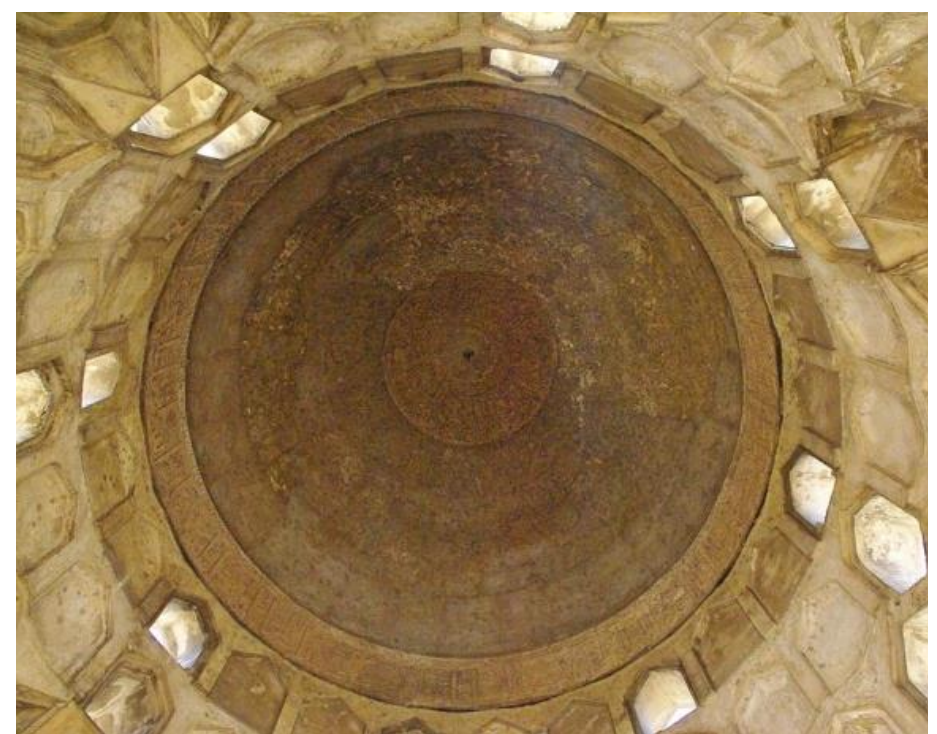

Figure 187: Interior of Sabil ablution fountain in Ibn Tulun courtyard.

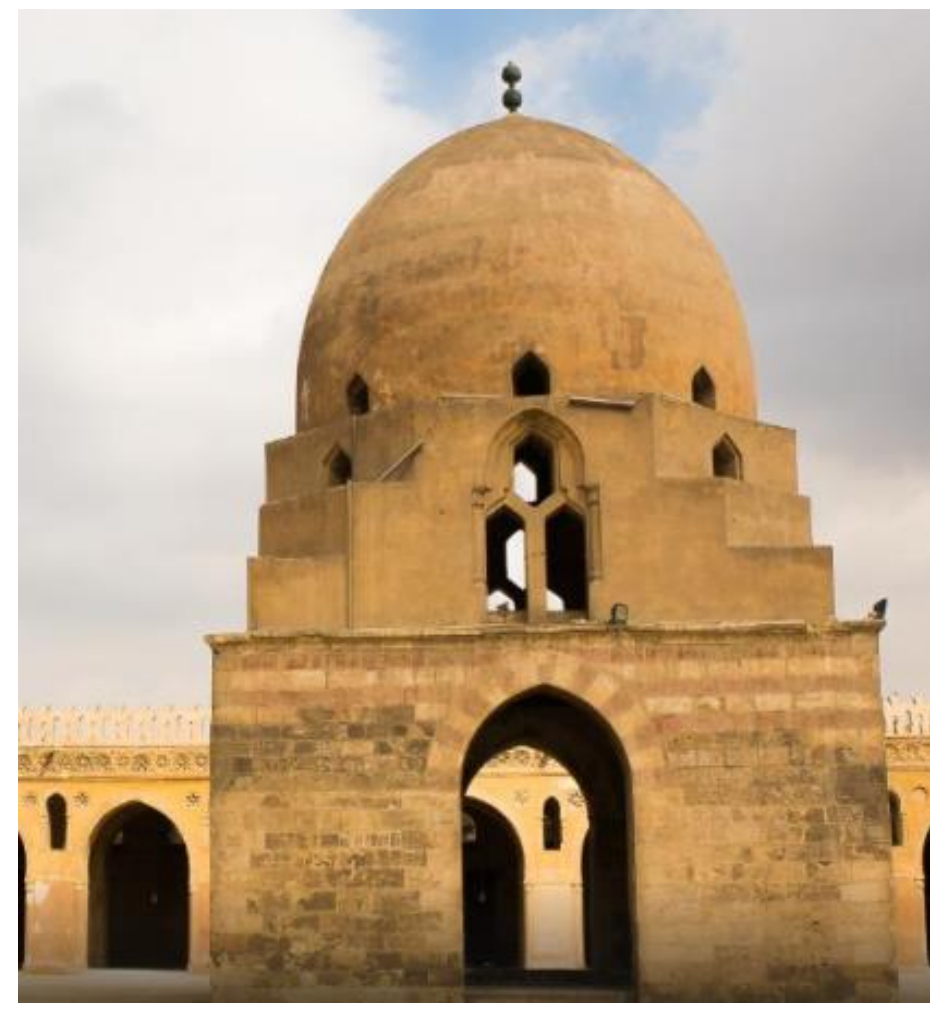

Figure 188: Ablution Fountain Dome, at the center of Ibn Tulun courtyard, 867 AD.

\section{Source: Archnet}




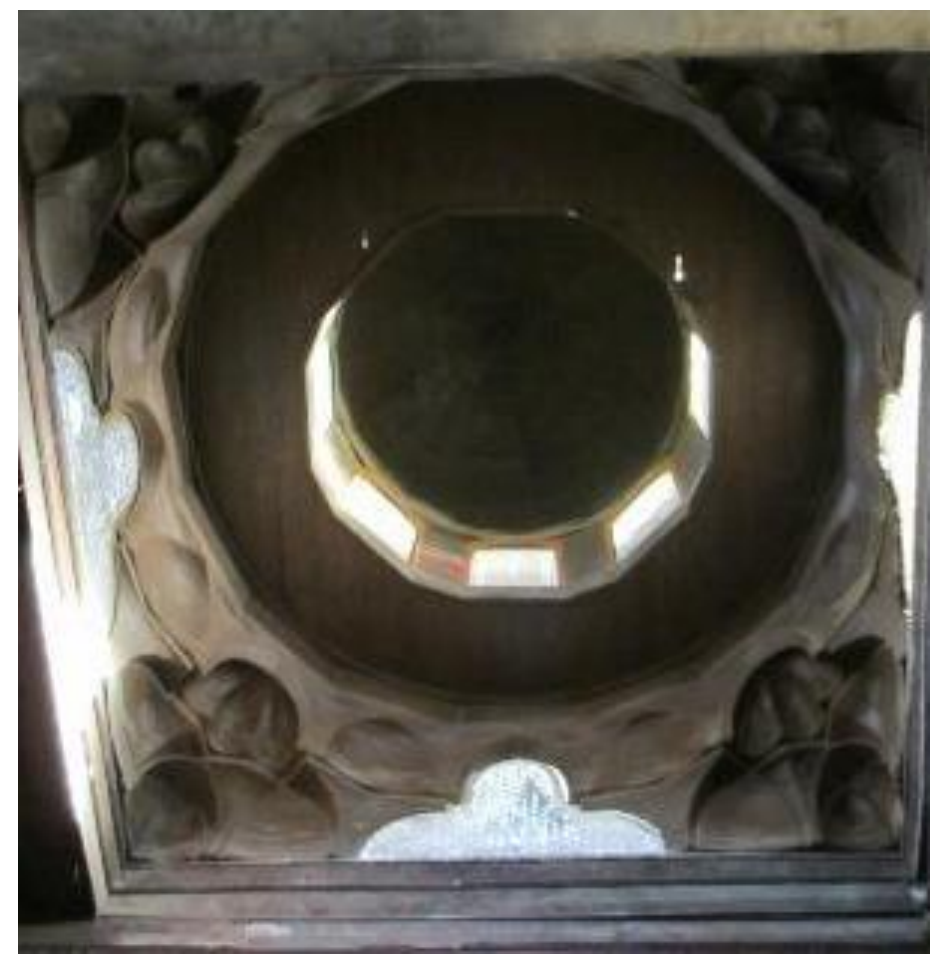

Figure 189: Mihrab Dome, Ibn Tulun

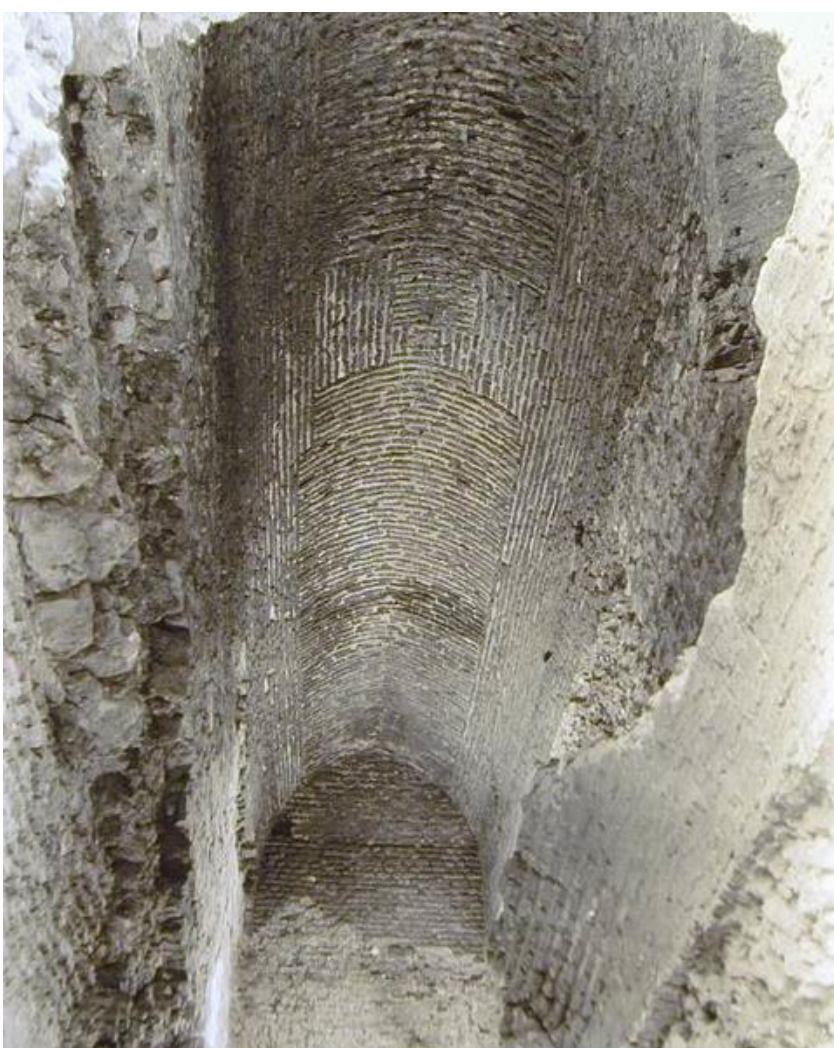

Figure 190: Barrel Vaults in Ibn Tulun Mosque 


\subsection{Ikhshid Introduction: 935 to 969 AD}

Ikhshid is title of Iranian rulers in Transoxiana during the preIslamic and early Islamic periods [1]. Samarkand was the capital

[1] (Gibb, 1923) of Ikhshids of Soghdia. Later, the dynasty reached Egypt and ruled from 935 to 969 AD. Muhammad ibn Tughj al Ikhshid, a Turkic slave soldier, was appointed governor by the Abbasid Caliph. The dynasty carried the Arabic title Wali reflecting their position as governors on behalf of the Abbasids. The Ikhshidids came to an end when the Fatimid army conquered Fustat in 969 AD. The Ikhshid brought Samarqand art to North Africa. It is considered one of the oldest cities in Central Asia, prospering from its location on the Silk Road between China and the Mediterranean. The city is noted for being an Islamic centre for scholarly study. Trade on the Silk Road was a significant factor in the development of the civilizations of China, the Indian subcontinent, Persia, Europe, the Horn of Africa and Arabia, opening long-distance, political and economic relations between the civilizations. Though silk was certainly the major trade item from China, many other goods were traded, and religions, syncretic philosophies, and various technologies. In addition to economic trade, the Silk Road served as a means of carrying out cultural trade among the civilizations along its network and Architecture. The main traders during antiquity were Chinese, Arabs, Persian, Somalis, Greeks, Syrians, Romans, Armenians, Indians, and Bactrians, and from the fifth to the eighth century the Sogdians. The city has carefully preserved the traditions of ancient crafts: embroidery, gold embroidery, silk weaving, engraving on copper, ceramics, carving and painting on wood [1] [2] [3] [4] [5] [6].
[2] (Michael BrettJ. D. Fage, Roland Anthony Oliver, 2002) P. 622

[3] (Creswell, 1940)

[4] (Hoag, 1987)

[5] (Behrens-Abouseif, 1989)

[6] (Karnouk, 1981) P. 113-139 


\subsection{Fatimid Introduction: 909 to 1171 AD}

Fatimids had strong relations with Persia for the mutual belief of the major branch of Ismaili Shiite belief [1]. They were in conflict with Abbasids Caliphate. Although Abbasid is famed as the Golden age of the Islamic expansions, but Fatimids is the golden age of the Ismaili branch [2]. The Ismaili branch established in 909 AD in Ifriqiya. Fatimids traced their origin to the Prophet's daughter Fatima and her husband Ali bin Abi Talib, who is acknowledged as the rightful imam by different Shiite communities. Ismailism served as the state religion, in many other Muslim Shiite lands including Persia and close regions [3]. Fatimids had diverse political relations with Persia and the major dynasties ruling there but centred in Tunisia then ruled over various areas of Maghreb, Sudan, Sicily, Levant and Hijaz from 909 to 1171 AD. They established the Tunisian city of Ragah then Mahdiya and made it their capital city. Later, they took control of Egypt and built the city of Cairo and made it their new capital in 969 AD. The wealth of Fatimid architecture was found in many cities [4]. The peak of their dynasty was in the eleventh century: The Great Mosque of Mahdiya or Jami' Al Kabir, is the oldest mosque- built in 916 AD [Figure 192: Mahdiya Mosque, 912AD which was influenced by The Great Mosque of Kairouan. The mosque has a rectangular plan enclosed with heavily fortified walls. The prayer hall consists of four bays deep and nine bays wide, the central nave to the Qibla is wider than the others. The Mihrab wall with two columns aside carries the Mihrab dome. The dome over the Mihrab is supported by a drum [Figure 194] [5] [6] [7]. Susan Yalman a member of the Department of Education, The Metropolitan Museum of Art stated:

'In architecture, the Fatimids followed Tulunid techniques and used similar materials, but also developed those of their own [8].'
[1] (Al-Amin, 2016)

[2] (Halm, 1997)

[3] (Daftary, 1990)

P. $144-273,615-59$

[4] (Canard, 1888)

P. 850-62

[5] (Halm 1996)

The seat of the Fatimids was later transferred to Egypt in $362 / 973$, and the dynasty was finally overthrown by Șalāḥ-alDīn (Saladin) in $567 / 1171$, when the fourteenth and last Fatimid caliph, al-'Āżed (555-67/1160-71), lay dying in Cairo.

[6] (Richard Ettinghausen, Grabar Oleg, and Blair Sheila, 1987) P.148-150

[7] (Michell, ,1978)

[8] (Yalman, 2001) 
a. Mahdiya Mosque

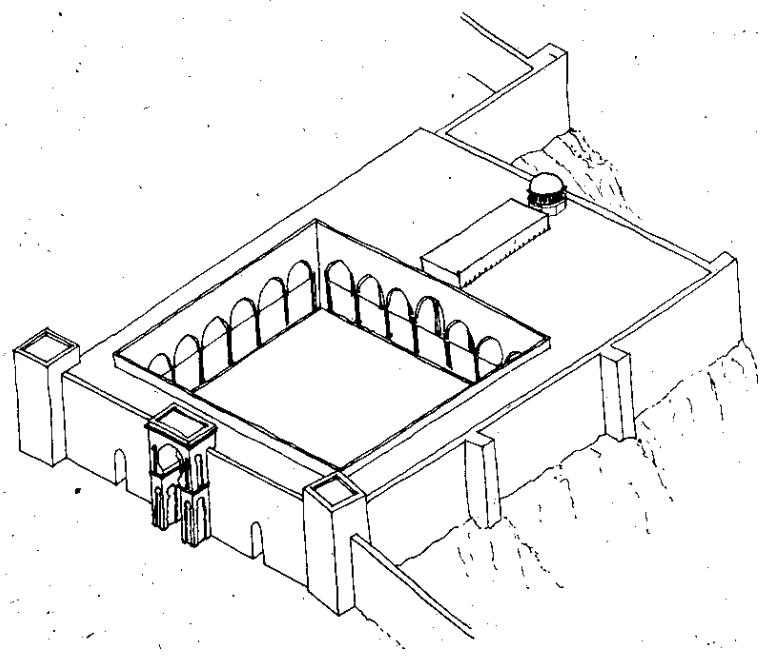

Figure 191: Mahdiya Mosque Plan, 912AD

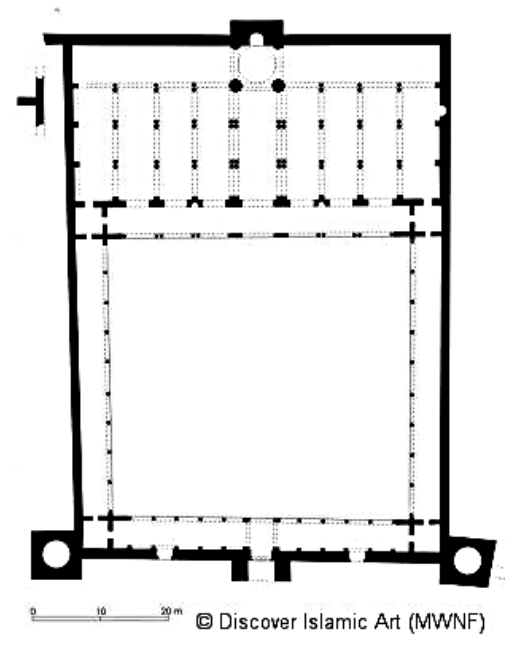

Figure 192: Mahdiya Mosque, 912AD

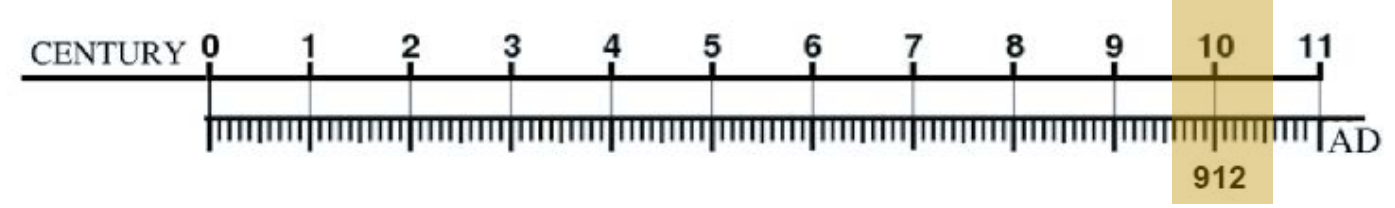

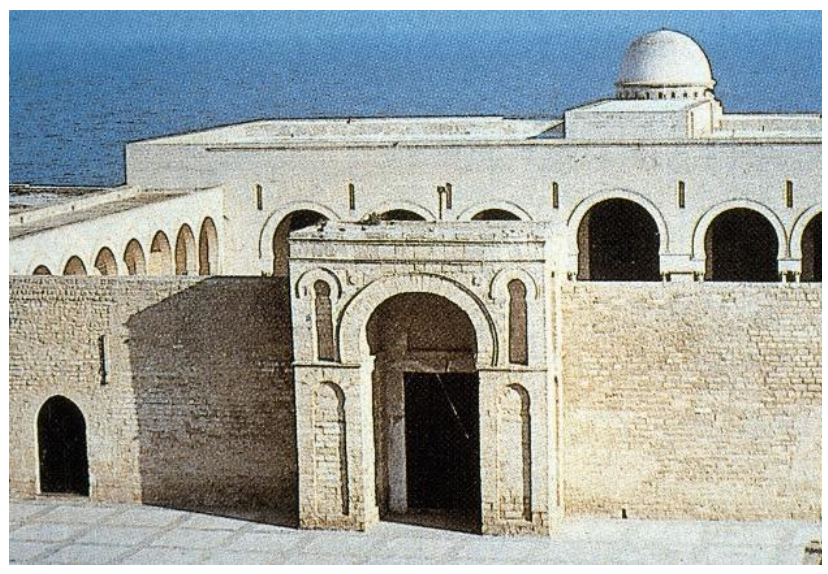

Figure 193: Mahdiya Mosque Plan, 912AD

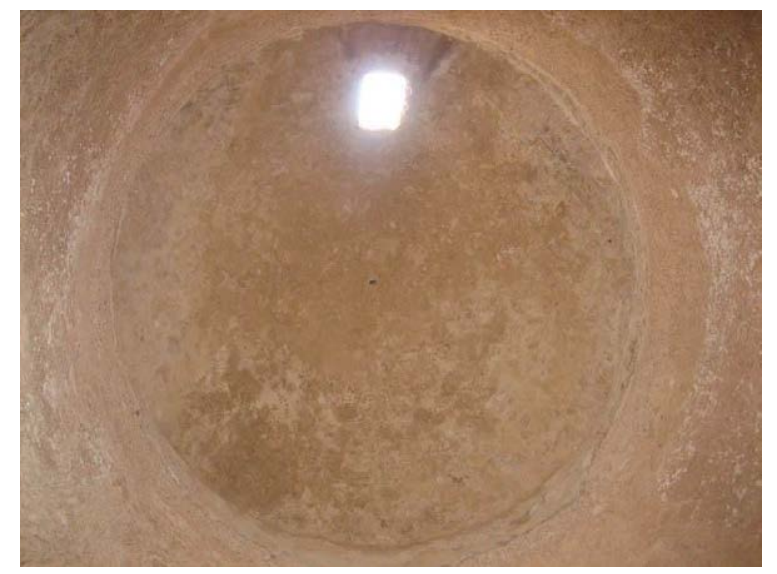

Figure 194: Mahdiya Mosque, 912AD

Source: Study Blue 


\subsubsection{Fatimid in Tunis}

Mansuriya City located near Kairouan was the capital of The Fatimid Caliphate during the rule of the Ismaili Shiite Branch ${ }^{39}$ after the invasion of Aghlabids. The Ismaili period was divided into two phases:

Al Mansur Billah in 946-953AD

Al Mu'izz li Din Allah in 953-975AD

During 946 -972AD, Mansuriya was the center of a powerful state encompassing most of North Africa and Sicily for a short period. Later, it served as provincial capital of Zirids independent dynasty until 1057 AD. This Dynasty was destroyed by Fatimids in Cairo after sending Banu Hilal tribes to demolish the Zirids [1].

[1] (Al-Amin, 2016 )

\subsubsection{Fatimid in Cairo}

As soon as the settlement of Fatimids were established in Cairo, they built impressive a Mosque named Al Azhar. Al Mu'izz liDin Allah commissioned its construction in 970AD. The Mihrab Dome was built over squelches [Figure 196]. The Mosque was inspired by the architecture of Ifriqiya, which was different then to Tulunid Architecture. A Hypostyle Plan consists of a wide central nave with two domes available on the ends which famed in Kairouan, Fes and Al Andalus. This Fatimids architectural structure was famous during their rule in Cairo and it spread. In 989 AD, the Al Hakim Mosque ${ }^{40}$ was constructed. The central nave in Mihrab is emphasized in width and height. At the end of the nave, a dome is carried on squinches over Mihrab [Figure 198] [2].

[2] (Halm, 1997)

\footnotetext{
39 Ismaili

${ }^{40}$ Named as well, Al Anwar
} 
a. Azhar Mosque

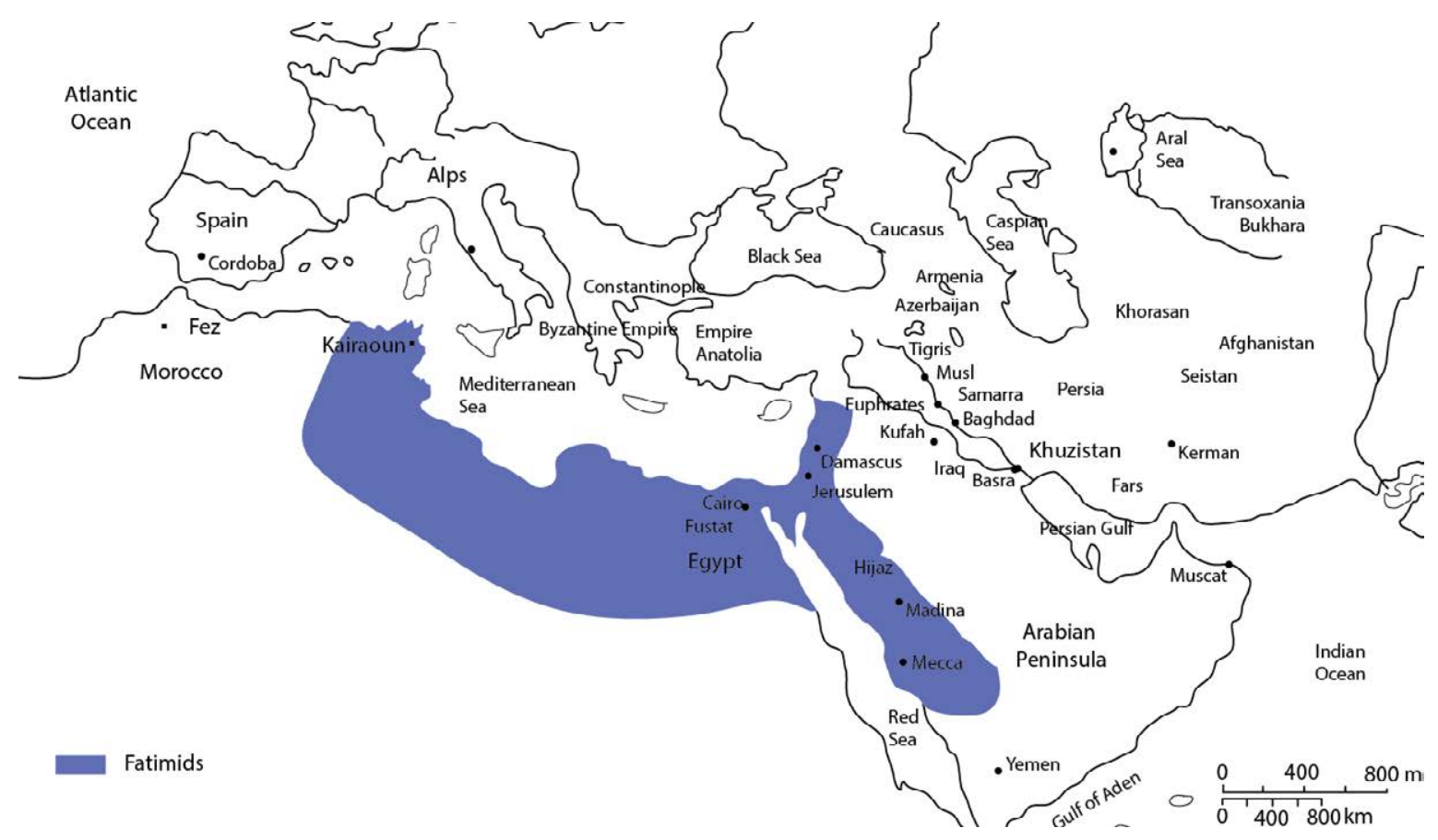

Figure 195: Location of Fatimid Dynasty

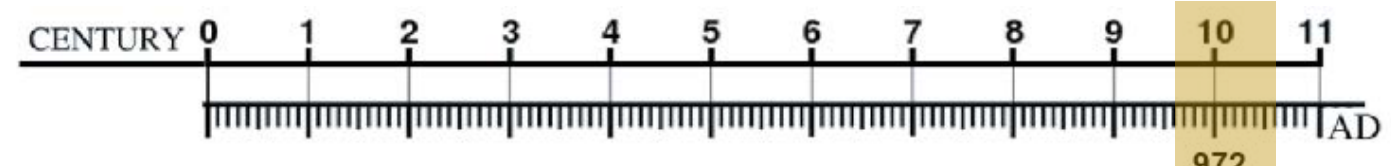

972

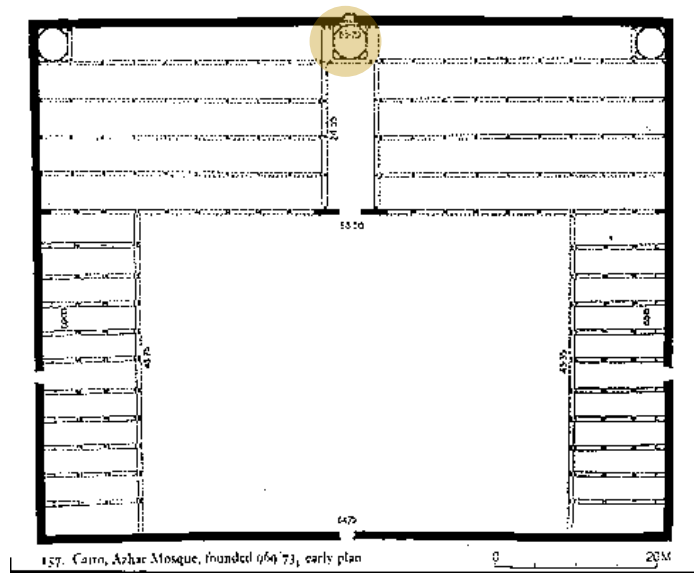

Figure 196: Azhar Mosque Plan, 972 AD Source: Archnet

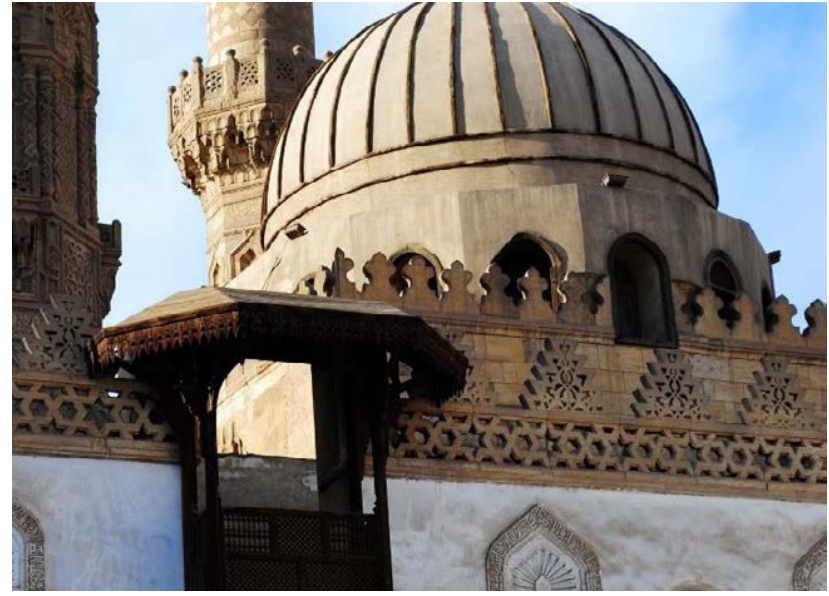

Figure 197: Azhar Mosque Mihrab Dome, 972 AD Photo by: Abu Bkr Al shinwani 


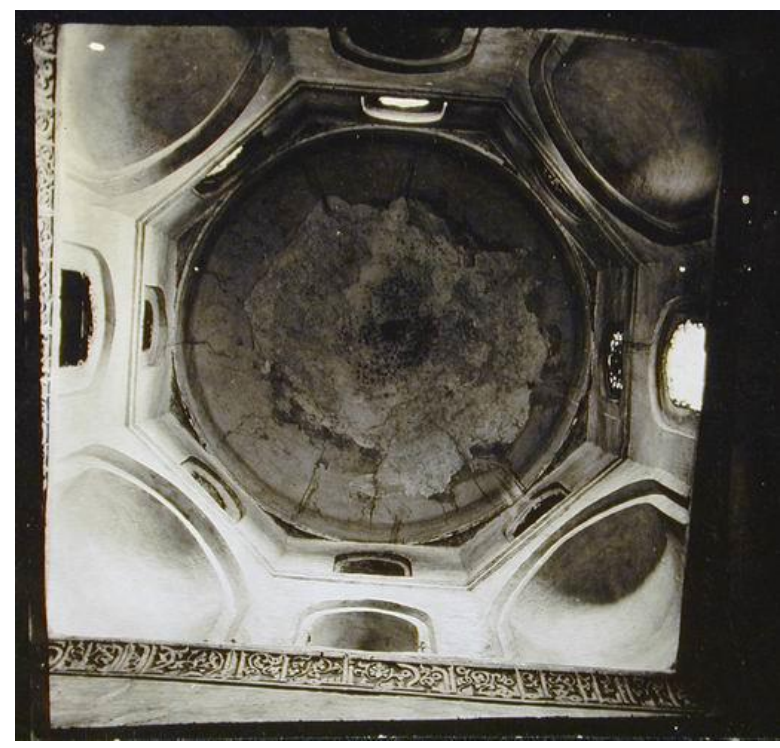

Figure 198: Al Azhar Mihab Dome

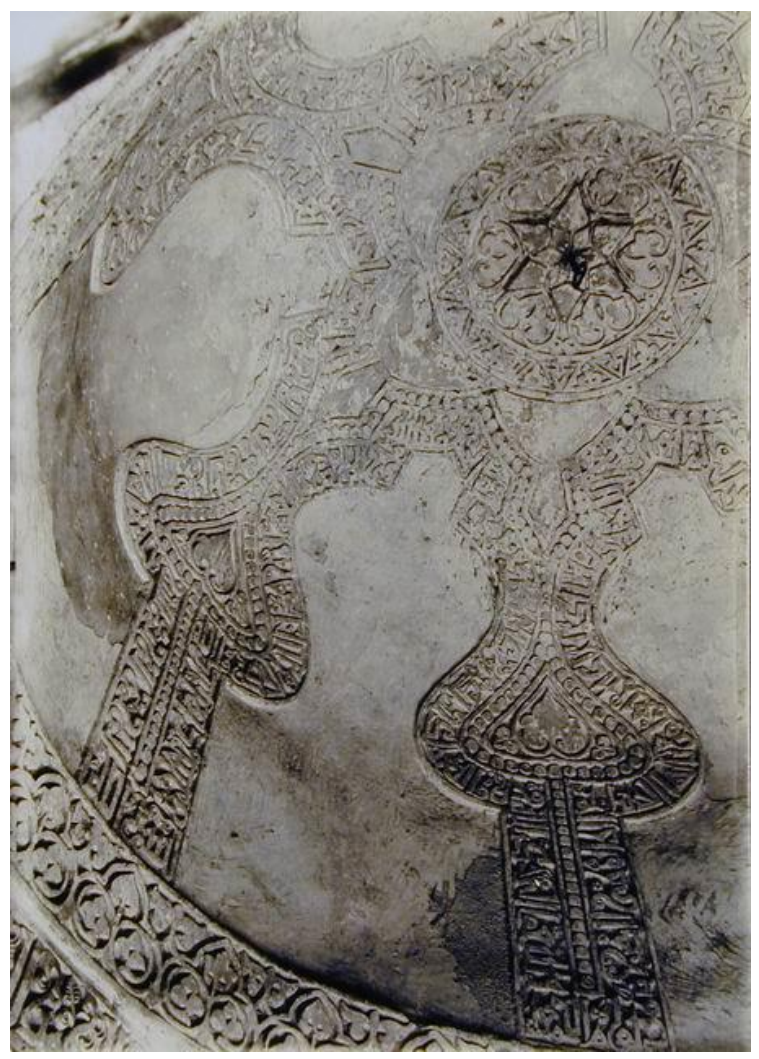

Figure 200: Stucco of Al Mihab Dome

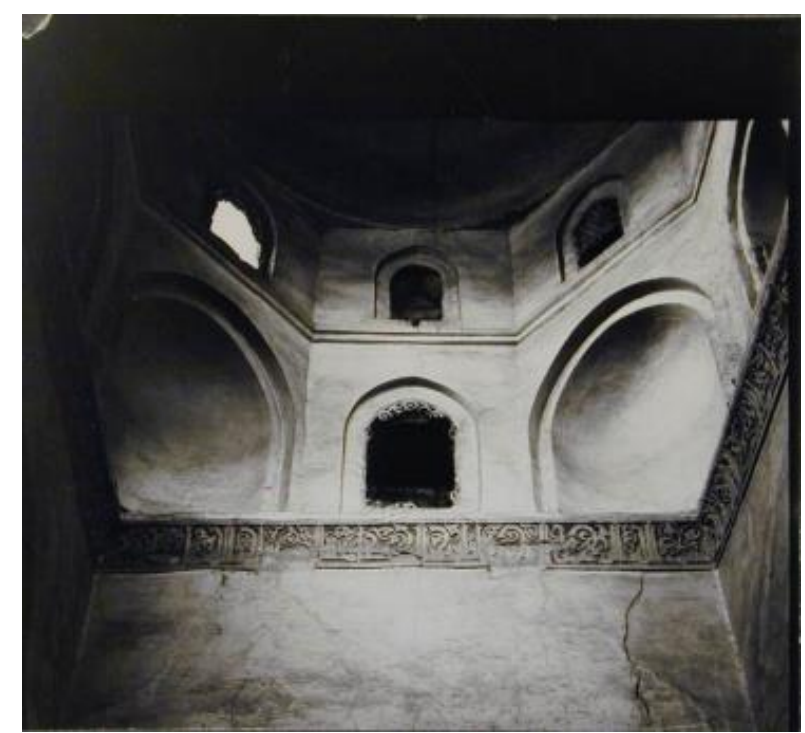

Figure 199: Azhar Dome

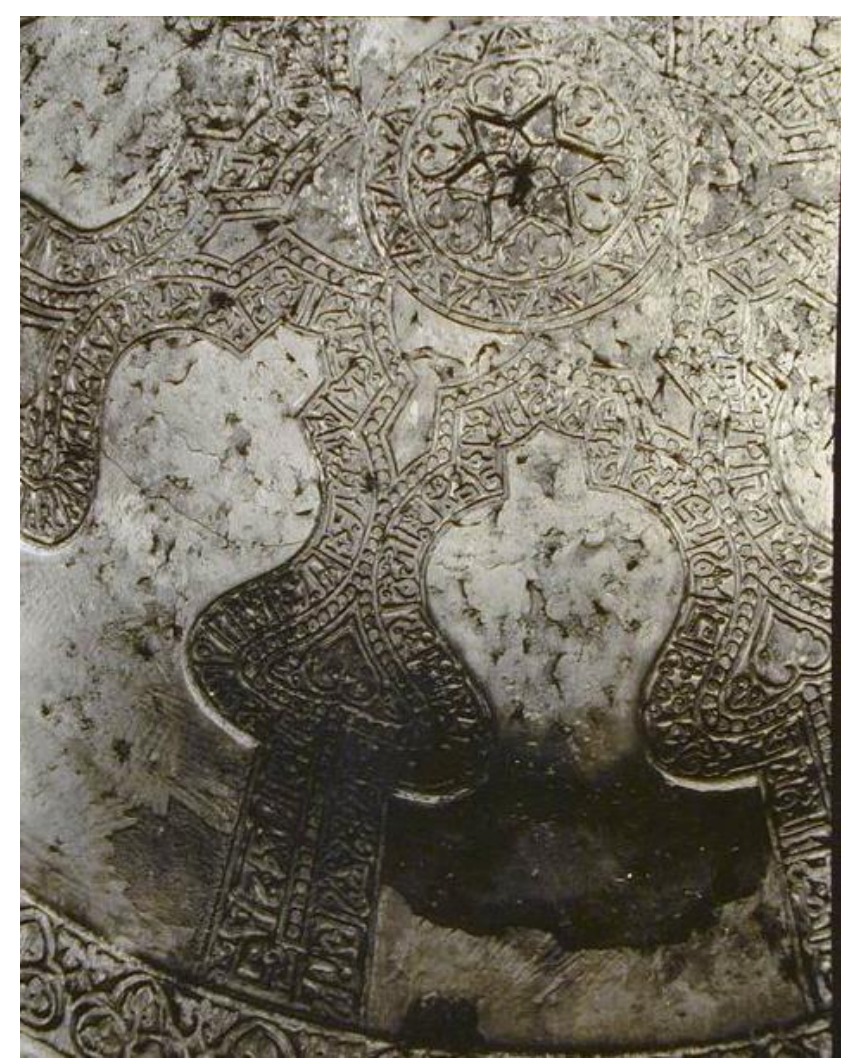

Figure 201: Stucco Dome close shot 


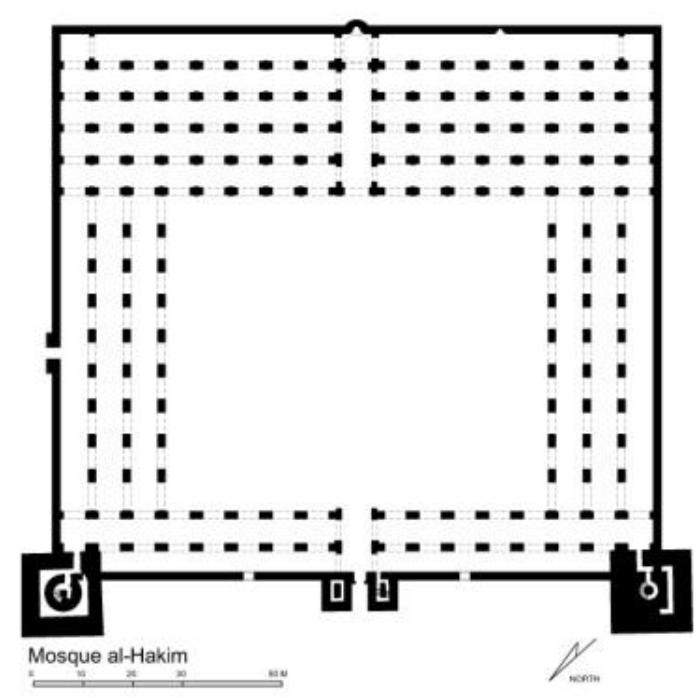

Figure 202:Al Hakim Mosque Plan, 989AD Source: Archnet

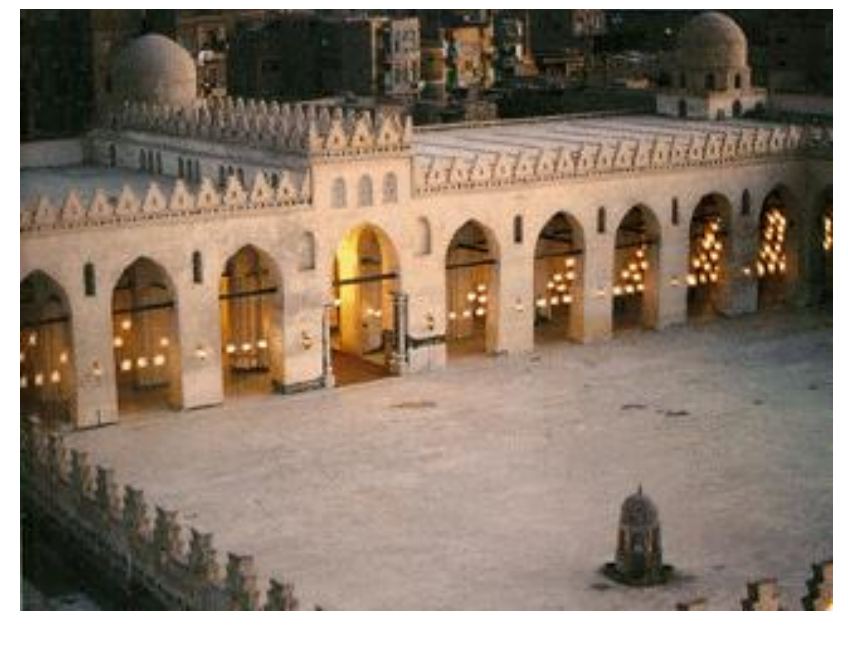

Figure 203: Al Hakim Mosque, 989AD Source: Al minshawi

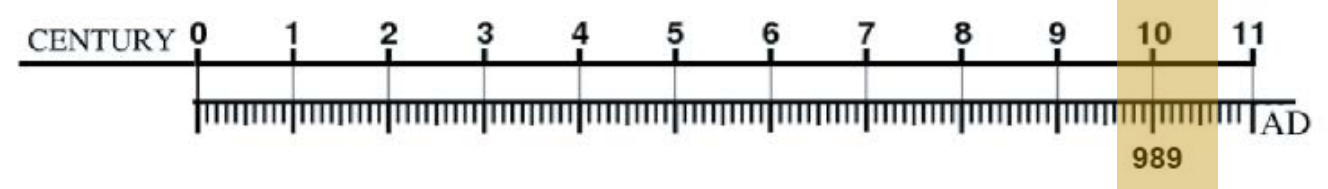

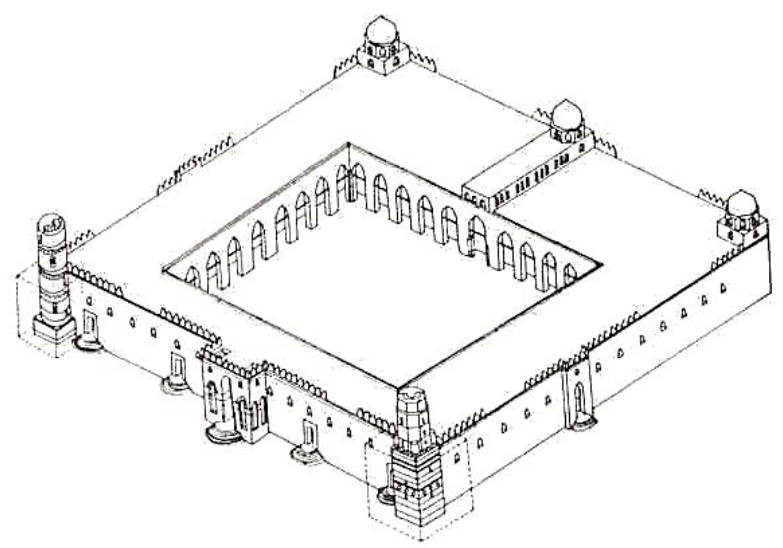

Figure 204: Al Hakim Mosque , 989AD

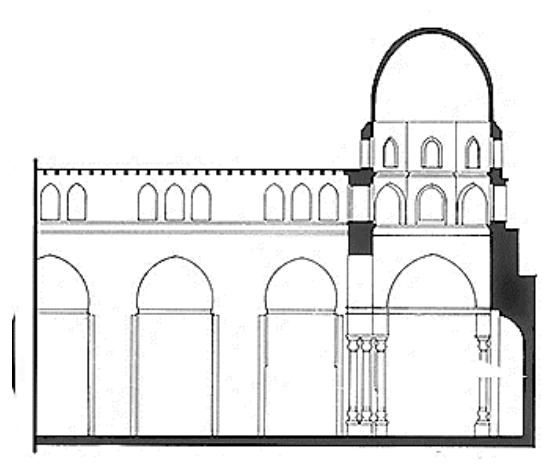

Figure 205: Al Hakim Mosque Section

Source: Archnet 


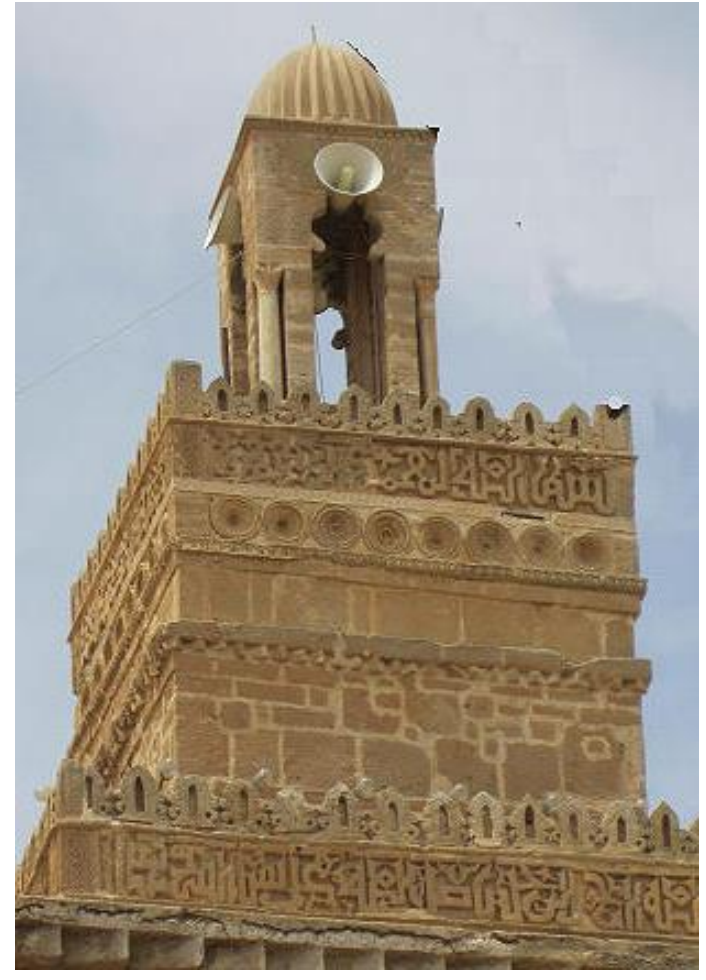

Figure 206: Great Mosque at Sfax, 849AD

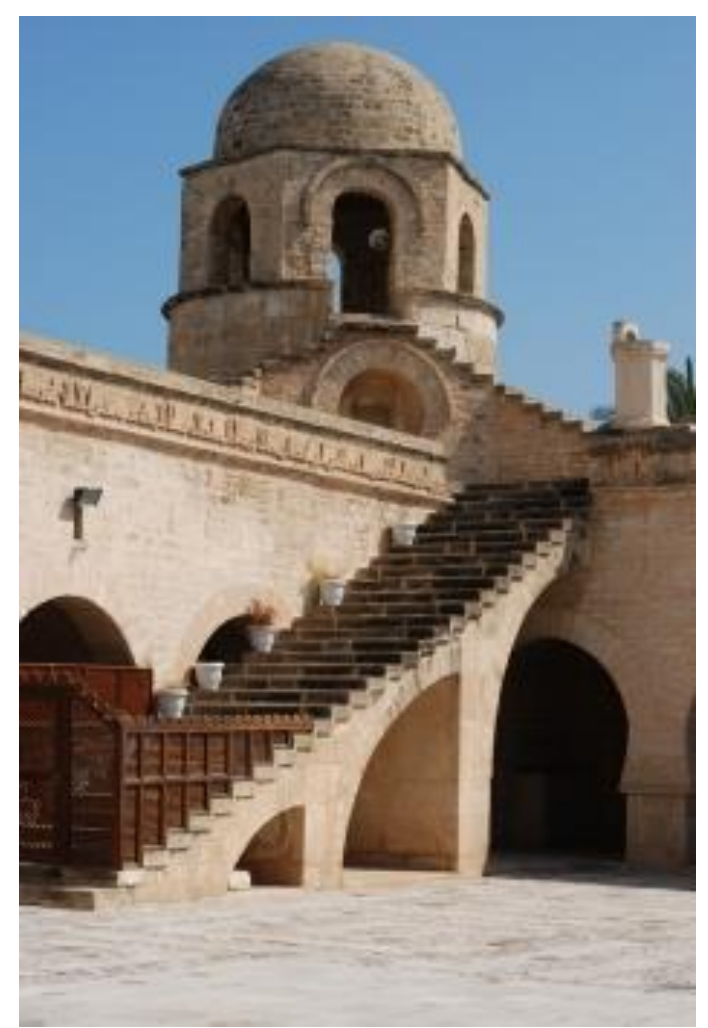

Figure 208: Great Mosque of Susa tower Dome, 851AD

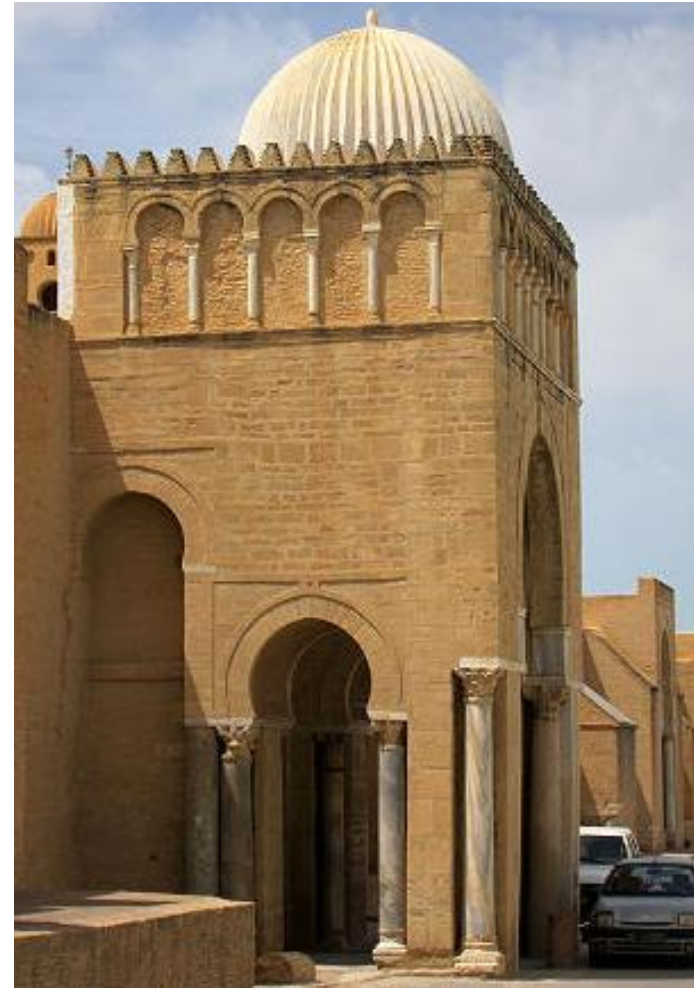

Figure 207: Great Mosque of Kairouan

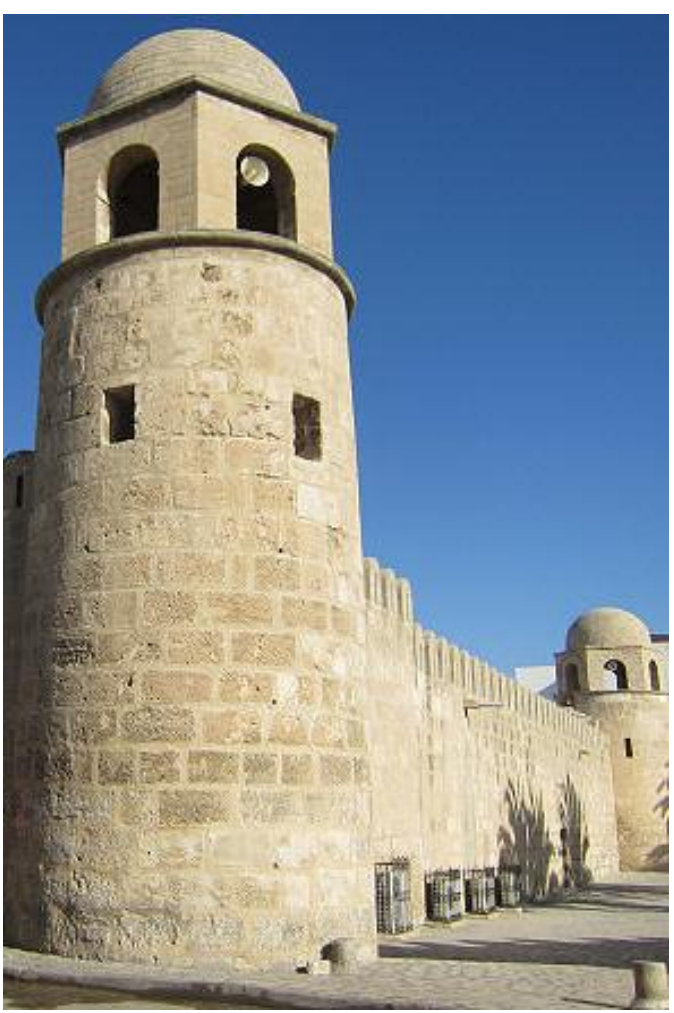

Figure 209: Great Mosque of Susa Tower Dome, 851AD 


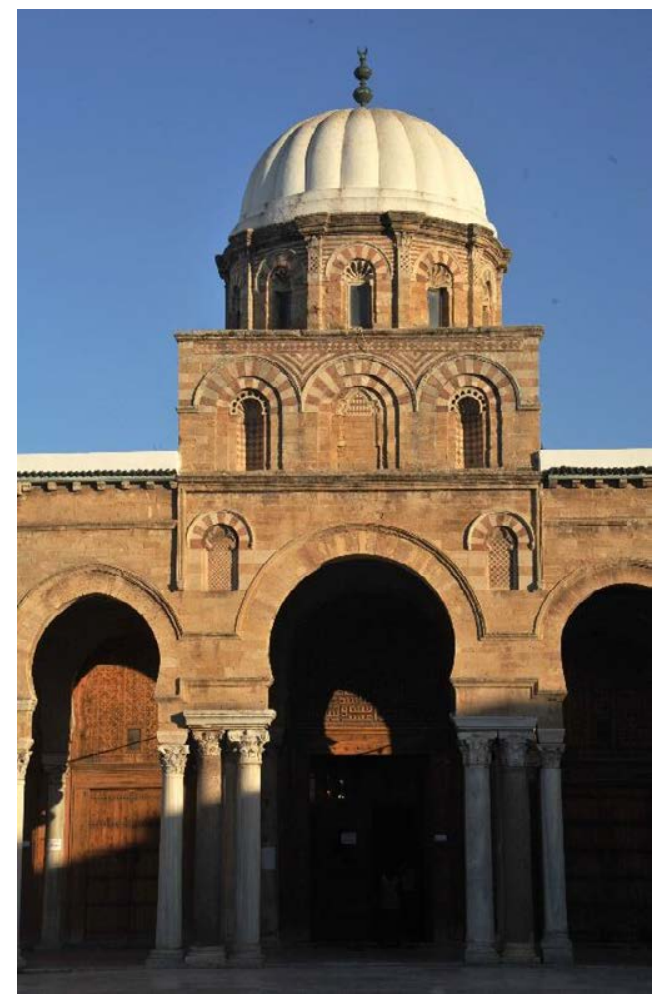

Figure 210: Zaytuna Mosque Chamber Dome

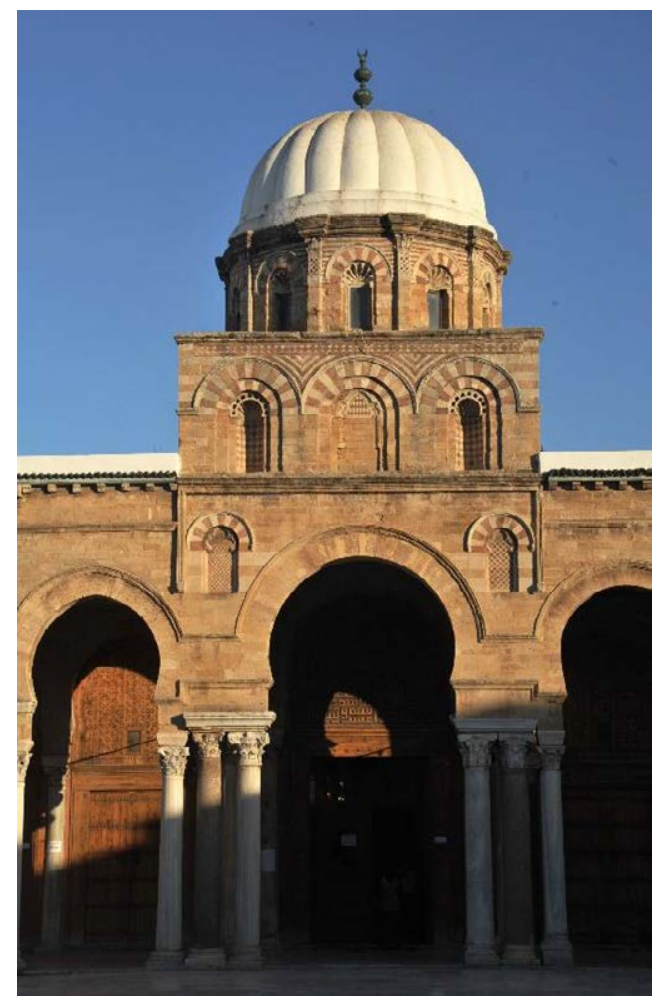

Figure 212: Great Mosque of Kairouan

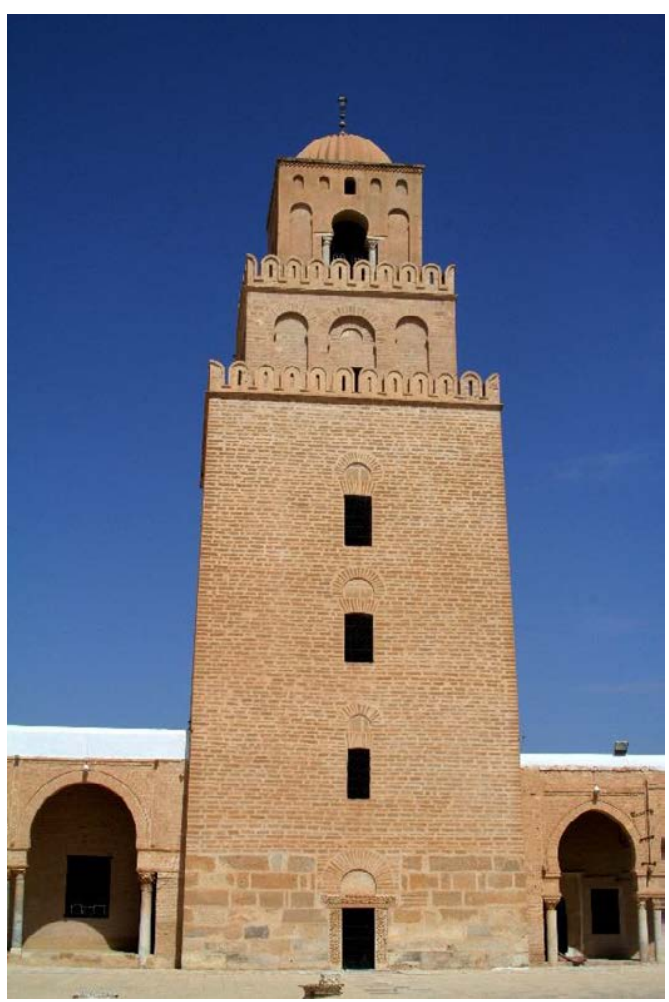

Figure 211: Great Mosque of Kairouan Minaret Dome

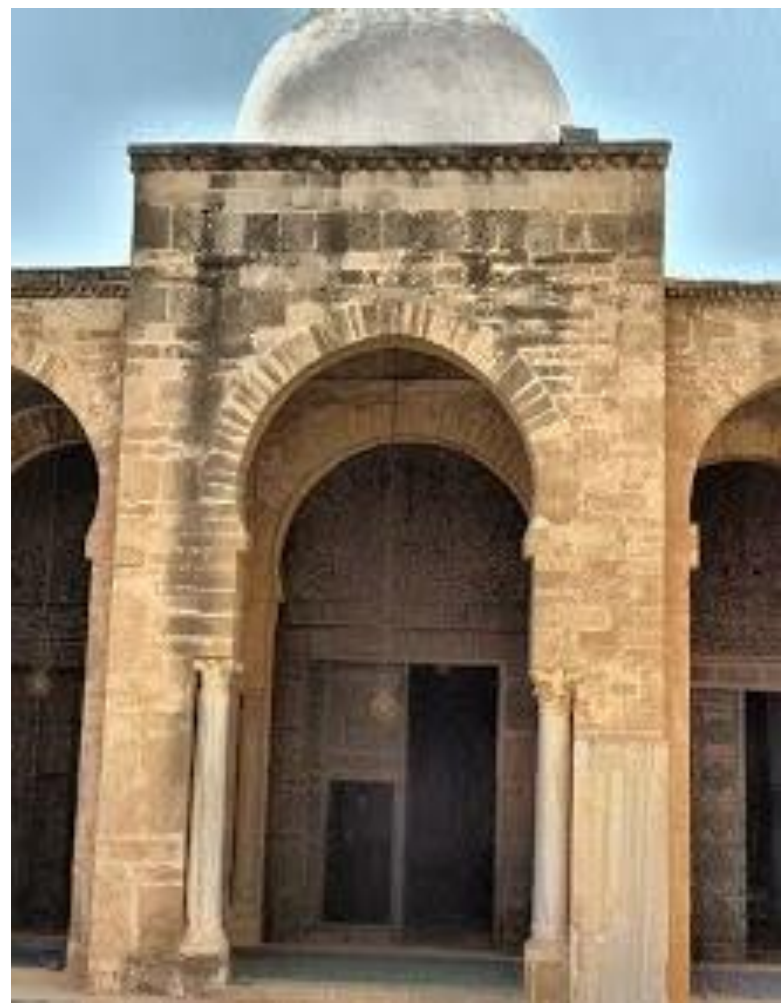

Figure 213: Great Mosque of Sfax Wikipedia 


\subsection{Zirid Introduction: 1048-1152 AD}

Tunisia, Eastern Algeria, Granada and Fatimid.

Zirids Sanhajah initially governors on behalf of Fatimids, were centred in Kairouan city with various branches, ruled over Africa, Tunisia, Eastern Algeria as well as Granada since 972 until 1152AD but declared themselves independent of Fatimids and Shiite religious policy in 1048AD under Al Mu'izz withdrew the Fatimid Caliphate in Cairo to Abbasid Caliphate in Baghdad. As a result, the Fatimid Caliph Al Mustansir ordered his minister, Abu Mohammed Al Hassan Yazouri and nomadic tribes of Banu Hilala and Bani Salim to march towards Tunisia and destroy the state of Sanhajah and their capital. This invasion resulted in dividing Tunis into several states. However, The Zirids were forced to abandon Kairouan and move to Mahdiya City, but their shattered state was no longer able to survive coastal attacks by Sicilian Normans and finally fell in 1148 AD. During the Zirid settlement in Mahdiya they rebuilt the great Mosque of Sfax. The Mosque was built by The Aghlabids in 849 AD but extended in 988 AD during the Zirid period [Figure 206]. It bears much similarity to the Great Mosque of Kairouan. But the decorative motifs are typical Fatimid-Zirid which can be found in several monuments in the tenth century [Figure 213]. Another group of Zirids, who had gone to Spain to serve with Berber's army in 1002-1008 AD then established themselves independently in 1012-90 AD in Granada under Zawi ibn Ziri. At the beginning of the eleventh century, Zirids were given the province of Ilbira and by 1038 AD they had extended their kingdom to include Jaen and Cabra. Malaga became the centre of the Zirids in 1058 AD but they were overthrown by the Mohads in 1090 AD [1]. 
a. The Great Mosque of Sfax

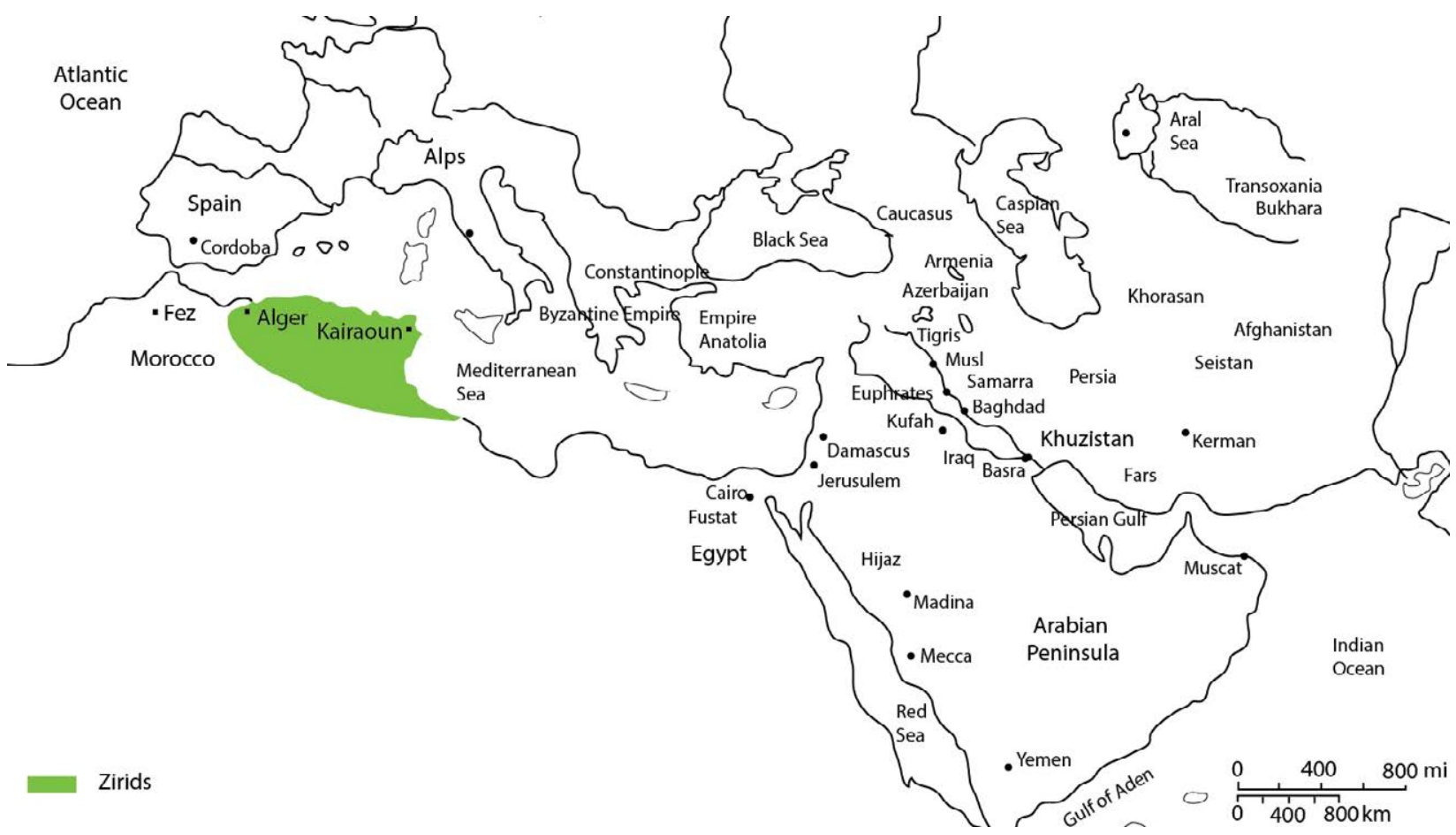

Figure 214: Great Mosque at Sfax, Location

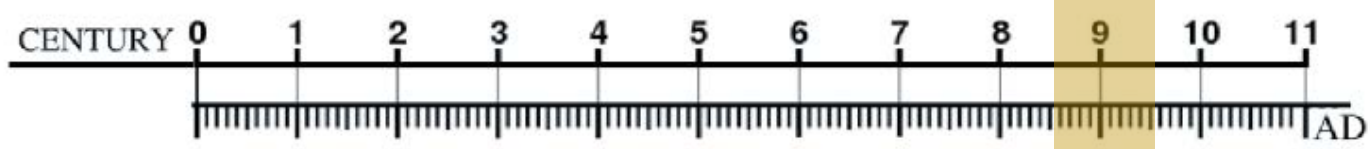

849
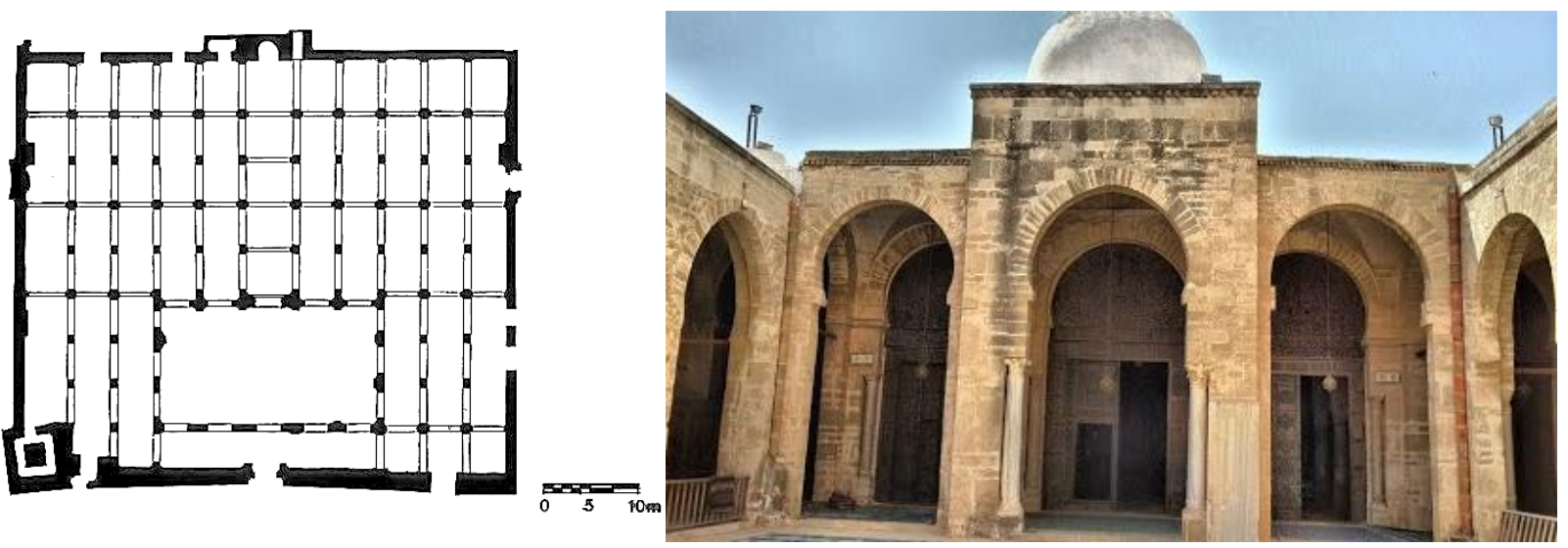

Figure 215: Great Mosque at Sfax, 849AD

Figure 216: Great Mosque at Sfax, 849 and extended in the Zirid era AD 988

Source: Archnet 


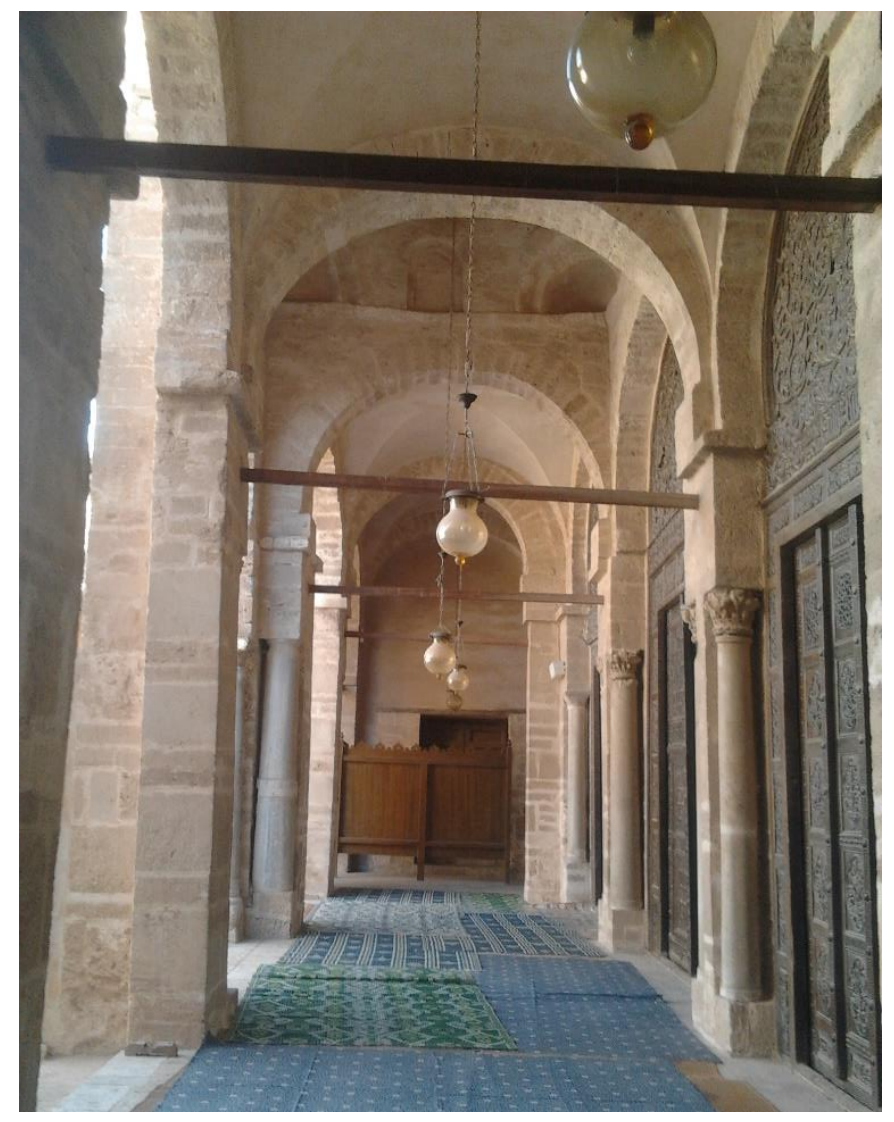

Figure 217: Great Mosque at Sfax, 849AD

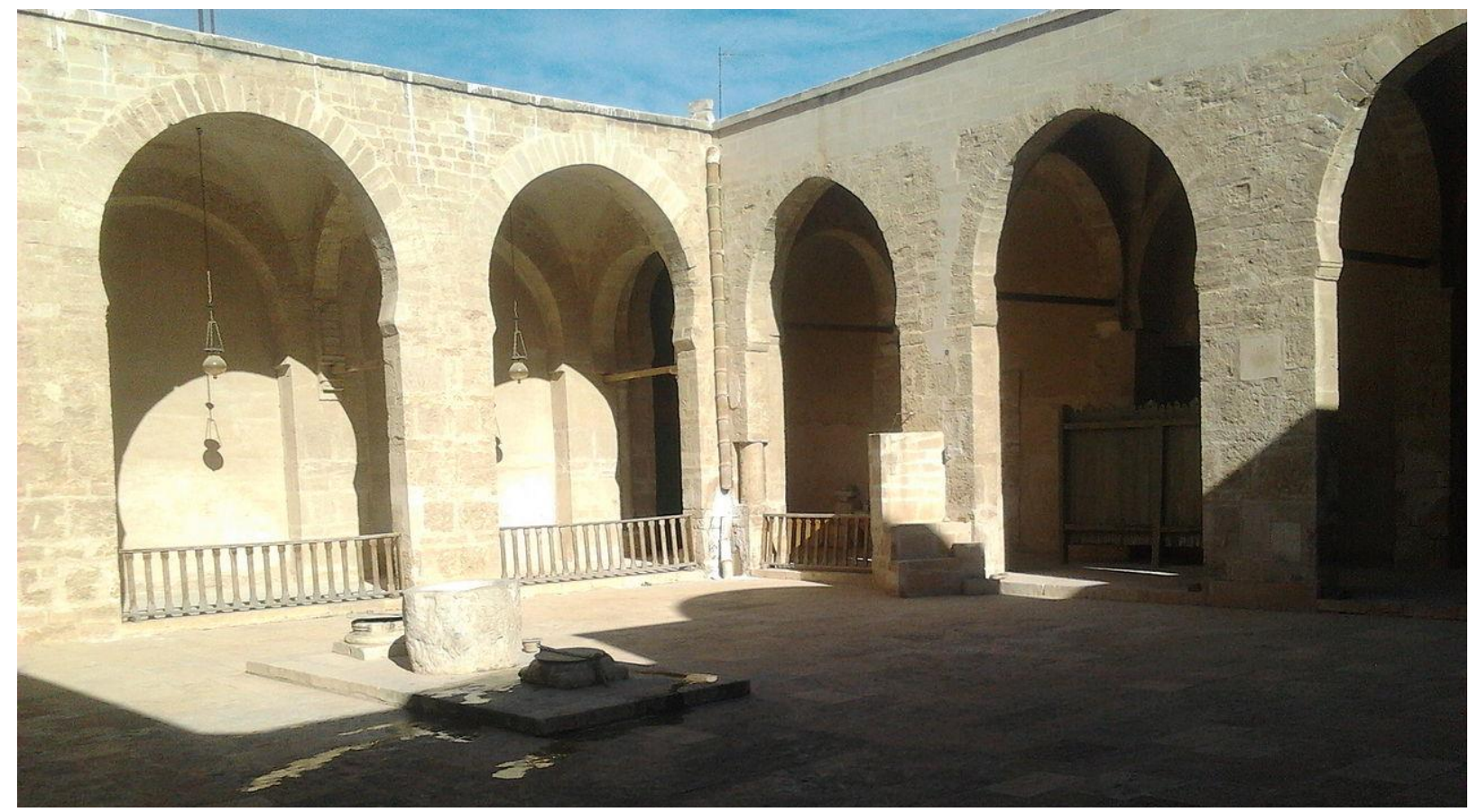

Figure 218: Sfax Chamber corridor vaults

Source: Wikipedia 
List of Islamic Dynasties in North Africa

\begin{tabular}{|l|l|c|c|}
\hline \multicolumn{1}{|c|}{ Dynasty } & \multicolumn{1}{c|}{ Location } & Period & Type o Vault \\
\hline Zirids dynasty & & $710-1019$ & Spherical \\
\hline Muhallabids & Ifriqiya & $771-793$ & Spherical \\
\hline Idrisid & Fes & $780-985$ & Spherical \\
\hline Aghlabids & Ifriqiya & $800-909$ & Lobbed - Zigzag \\
\hline Fatimid Caliphate & & $909-1171$ & Spherical \\
\hline Tahirids & Egypt & & Pitched Brick \\
\hline Tulunid & Egypt & $868-905$ & Spherical \\
\hline Ikhsisid & Egypt & $935-969$ & Zigzag \\
\hline Zirid Fatimids & Ifriqiya & $973-1148$ & \\
\hline Hammadid & Western Ifriqiya & $1008-1152$ & Zugarnas -Cross Arches \\
\hline Moravid & Morocco and Al-Andalus & $1040-1147$ & Mugzag \\
\hline Almohad & Morocco and Al-Andalus & $1130-1147-12$ & Muqarnas -Cross Arches \\
\hline Ayyubids & Egypt & $1171-1341$ & Lobbed - Zigzag \\
\hline Hafsid & Ifriqiya & $1229-1574$ & Muqarnas \\
\hline Nasrid dynasty & (Granada & $1232-1492$ & Cross Arches \\
\hline Ziyyanid dynasty & Tlemcen & & Muqarnas -Cross Arches \\
\hline Marinid dynasty & Morocco & & \\
\hline
\end{tabular}

Table 7: Islamic Dynasties in North Africa 


\subsubsection{Abbasid Introduction in Central Asia: 750-1258 AD}

Bagdad was the capital of the Abbasid Dynasty. The evolution toward Umayyads started from central Khorasan until it reached Damascus to demolished Umayyad Caliphates and establish the Abbasid caliphates in Bagdad. Bagdad is located in north Ctesiphon ${ }^{41}$, which was the great city of the late Ancient Mesopotamia, where the Tigris and Euphrates rivers had developed the use of clay masonry and buildings of stacked mud bricks [1]. The Sassanian architectural methods had influenced the Abbasid Architecture when the Persians converted their beliefs to Islam [2]. Sassanid comprised, Iran, Iraq, and eastern Arabia including Bahrain, Kuwait, Oman, Qatif, Qatar and UAE, beside the Levant: Syria, Lebanon, Palestine and Jordan, It included the Caucasus areas: Armenia, Georgia, Azerbaijan, Dagestan, South Ossetia and Abkhazia. Also, Egypt and large parts of Turkey, Central Asia including Afghanistan, Turkmenistan, Uzbekistan, Tajikistan, and Yemen and Pakistan [3].

'The Sassanid period had witnessed the peak of Ancient Iranian Civilization in addition it influenced the territorial borders. It played a prominent role in the formation of Asian Medieval Art which later became known as Islamic culture in architecture and have been transferred from the Sassanid throughout Muslim expansions to the world [4].

Between 750 and $833 \mathrm{AD}$, the Abbasid art and science raised particularly during the period of Al Mansur during 714-775AD, Harun Al Rashid in 766 -809 AD and Al Ma'mun 813-833 AD when he ruled Persia and Transoxiana and made Merv the capital of Khorasan. The distance location of Bagdad created sub dynasties in Far Eastern and Western regions of the Abbasid Caliphate. The big number of
[1] (Petersen, , 1996)

[2] (Ettinghausen, Richard; Grabar, Oleg; Jenkins, Marilyn , 2001). P. 53

[3] (Hoag , 1987)

[4] (Fattah, 2009)

P. 49

\footnotetext{
${ }^{41}$ Ctesiphon was the capital city for both Parthian and Sassanian Empire
} 
leaders during the Abbasid Caliphates had created minor Dynasties in different regions. These Dynasties was initially ruled by Abbasids but became independent or demolished before their independence or recontrolled by Abbasids again.

The Abbasids expansions had inherited the Persian architectural traditions to Muslim's architectural art. Although Abbasids had lost control of large parts of their empire though their Realm but the architecture continued to be copied by successor states in Iran, Egypt and North Africa and extended further [ Figure 219][1].

[1] (Robinson, 2000)

\subsection{Islamic Dynasties in Central Asia}

The period can be devised into phases and domains:
i. Abbasids Caliphate: 750 AD
a. Haroun Calipha Period : Golden Age: 786-809AD
b. Ma'mun in Khorasan 813-833AD
ii. Tahirids: $820-873 \mathrm{AD}$
iii. Samanid: 900AD
iv. Buyids: 932AD

Other Muslim Independent dynasties:
v. Tulunid
vi. Seljuqs
vii. Hamdanids
viii. Qarakhanids
ix. Saffarid 


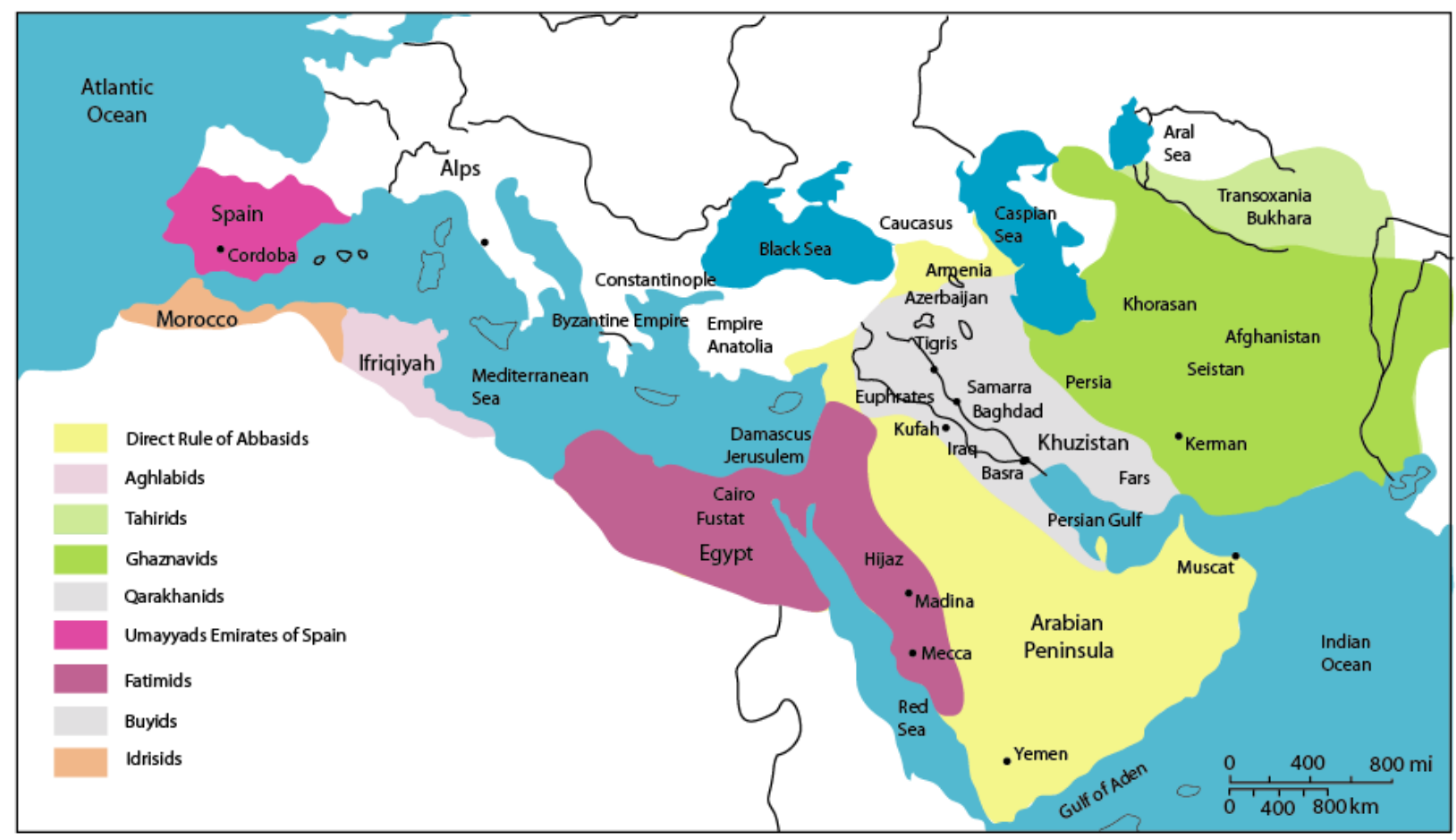

Figure 219: Sub-Dynasties 


\subsubsection{Tahirid: $820-873$ AD}

Merv then Nishapur in Iran

Tahirids governed the Abbasid province of Khorasan from 820 until 873 AD. Then ruled the City of Baghdad from 820 AD until 891 AD. The Dynasty was founded by, Tahir ibn Husayn, a general leader assigned by Abbasid caliph Al Ma'mun. The capital of Tahirids in Khorasan was initially located at Merv, but later moved to Nishapur. The Tahirids enjoyed a high degree of autonomy in their governance of Khorasan, although they remained subject to the Abbasid caliphate and were not independent rulers. The founder of the Tahirid dynasty Tahir ibn Husayn, had previously been awarded minor governorships in eastern Khorasan for their service to the Abbasids. In 821AD, Tahir was made governor of Khorasan, but he died soon afterwards. The caliph appointed Tahir's son, Talha, to Khorasan and his other son, Abdullah, as wali ${ }^{42}$ of Egypt and the Arabian Peninsula. Abdullah is considered one of the greatest of the Tahirid rulers. He is perhaps the most famous of [1 (Frye, 1999) P. $90-91$ the Tahirids [1] [2]. Tahirids had adopted the Simple Arab Plan Mosque with the Zoroaster Sassanid Gumbad roof methodologies

[2] (Daniel, 1997)

\subsubsection{Saffarid: 861- 1003 AD}

In 861 AD, The Saffarid Dynasty established from Sistan and ruled over parts of Eastern Iran, Khorasan, Afghanistan and Baluchistan. This dynasty lasted till 1003 AD. The dynasty is Persian origin founded by, Ya'qub Al Saffar, who was born in a small town in what is now Afghanistan. Ya'qub started conquering most regions of Iran and Afghanistan, as well as parts of Pakistan, Tajikestan and Uzbekistan. The

\footnotetext{
${ }^{42}$ Governer
} 
Saffarids used their capital Zaranj as a base for a massive expansion east and west ward. Saffarids invaded the areas south of the HinduKush in Afghanistan and then overthrew the Persian Tahirids dynasty, invading Khorasan in 873 AD. By the time of Ya'qub's death, The Dynasty suffered a defeat by Abbasids. The Saffarid Empire did not last long after Ya'qub's death. Its flourished was during the ninth century [1].

\subsection{Great Khorasan Introduction: 651 - 820 AD}

Greater Khorasan has witnessed the rise and fall of many dynasties and governments in its territory throughout history. Various tribes of Arabs, Turks, Kurds, Mongols, Turkmen and Afghans had brought change to the region in time. Ancient geographers divided Persia into eight segments of which the most flourishing and largest was the territory of Greater Khorasan. Thus, Khorasan was divided into four parts during the Muslim conquest of Persia named after the four largest cities: Nishapur, Merv, Herat, and Balkh. Khorasan territory was remained by Abbasids since in 651 AD until 820 AD when Tahirid ruled the area in the year 896 AD. Then the Samanid dynasty in 900 AD. Nishapur reached the height of its prosperity under the Samanid in the tenth century. Later, Mahmud of Ghazni conquered Khorasan in 994 AD and in the year 1037 AD Tughrul Beq, the first of the Seljuq leader to rule Nishapur. Mahmud Qaznavi retaliated against the invaders several times, and finally the Qaznavi Turks defeated Sultan Sanjar. In 1157 AD, Khorasan was conquered by Khwarazmids, a Sunni Muslim dynasty of Turkic Mamluk origin. The dynasty ruled large parts of Greater [2] (Research Group , 2007) Iran during the High Middle Ages [2]. 


\subsection{Iran Introduction}

The Islamic conquest of Persia in 633-656 AD had ended the Sasanian existence to new phase in Iranian history. This led to the eventual decline of The Zoroastrian religion in Persia, but kept its architecture [1]. However, the achievements of the previous Persian civilizations extended during the Islamic period and got absorbed by Muslims to create a new context of Islamic civilization [2] [3] [4]

\subsubsection{Iran Domes from Zoroastrians to Muslim Era}

Zoroaster is the ancient pre-Islamic religion of Persia. After Arab Islamic conquest, many Zoroastrians from neighbourhoods moved to Yazd Province and settled there. Yazd remained Zoroastrian even after the Islamic conquest by paying the levy ${ }^{43}$. Gradually Islam became the dominant religion in the city. Yazd Province, was known for the high quality of its handicrafts in Iran [5].

Sanjoy and Shampa Mazumdar did a comparative analysis between the Zoroastrian and Islamic complexes in Iran in their book: Religious traditions and domestic architecture explaining:

'The Zoroastrian religion and Islam are monotheistic religion which made a continue development in the Architecture approach. In Zoroastrians Religion, Fire is sacred to Zoroastrians. For this, the Fire temple is the major architecture in the area. Which led to the beginning of Cahartaq: Late Sasanian and early Mid Evil [6].'

Scholars had agreed in different citations on the similarity in plans between excavated fire temples and Islamic shrines where Gumbad or vaults often make it extremely difficult to determine the original function of unexcavated Cahar taq, especially in Fars and Kerman
[1] (Encyclopedia Britannica, 2016)

[2] (Research Group , 2007)

[3] (Bier, 1986). P. 63

[4] (Pope, 1931)

[5] (Sanjoy and Shampa Mazumdar, (1997)

[6] (Schippmann, 1971), P. 505

[7] (Huff, 1975), P. 244

[8] (Boucharlat, 1985). P. 464

[9] (Bier, 1986). P. 63

\footnotetext{
${ }^{43}$ Amount of money that must be paid collected by the authority.
} 
provinces where Zoroastrianism and Islam flourished side by side in the first centuries after the Arab conquest [Figure 221] [7] [8] [9].

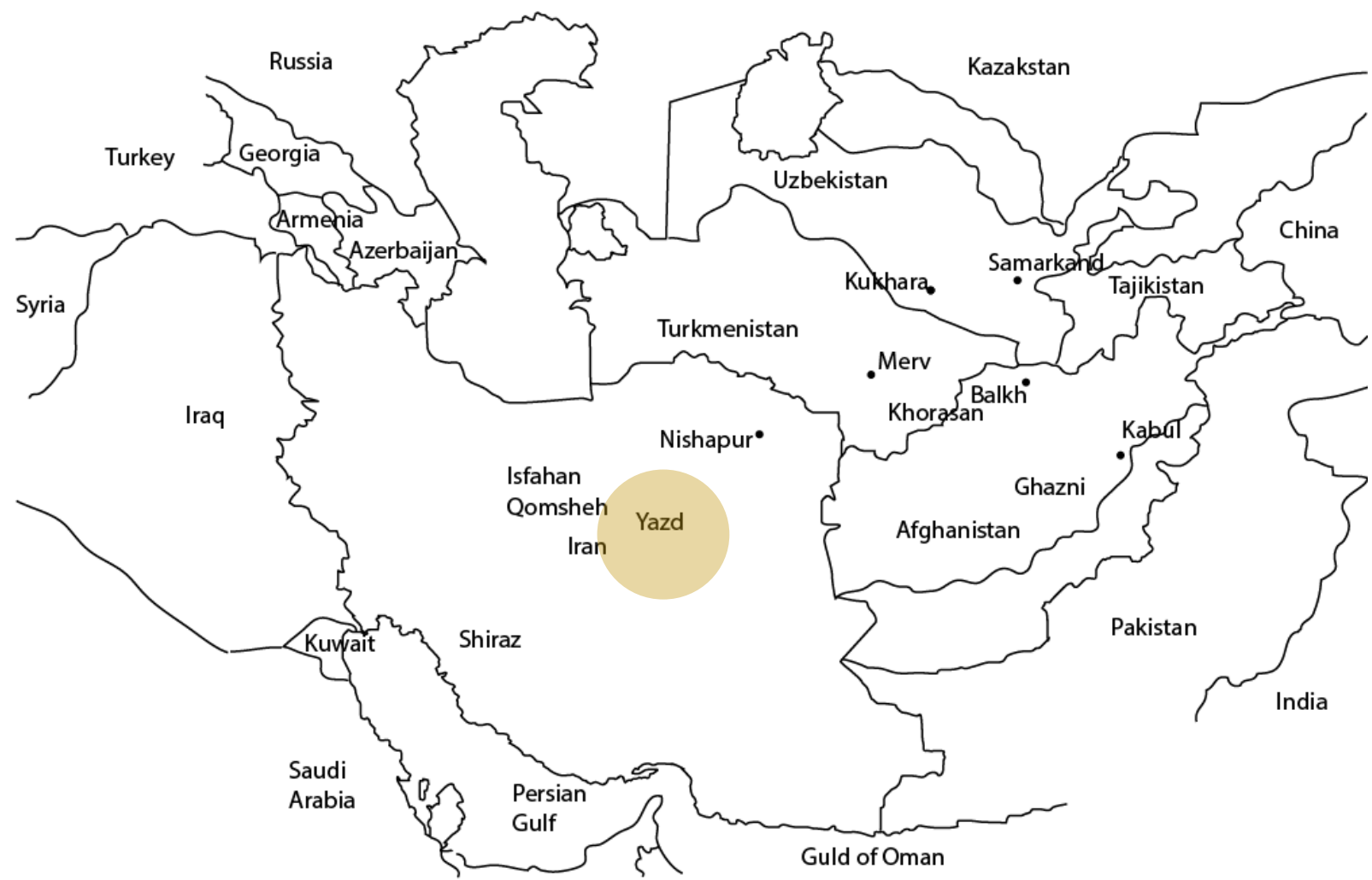

Figure 220: The center of Zoroastrian Architecture during Sassanid Era

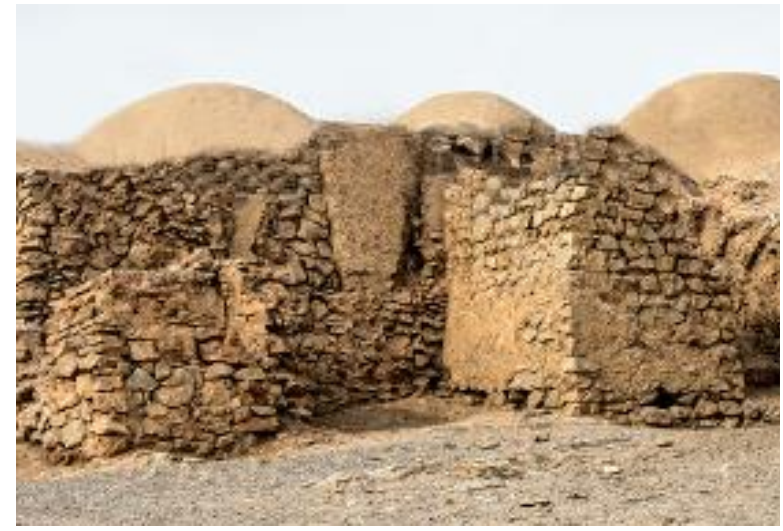

Figure 221: Vaults before Islam vaults

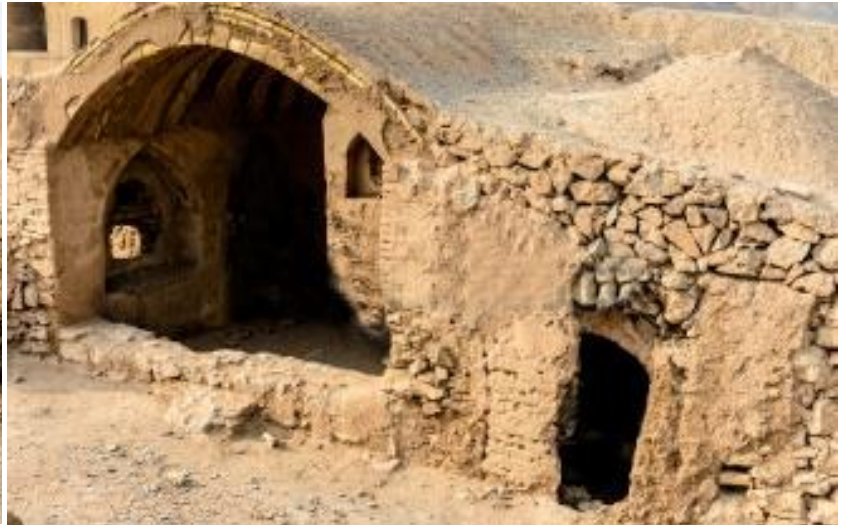

Figure 222: Vaults in Sassanid Era 


\section{a. Fahraj Mosque: 750-789 AD}

\section{Yazd in Iran}

Jami of Fahraj is thirty kilometres east of Yazd City in Iran. The mosque represents the evolution stage in mosque construction from lintel systems to full scale vaulting roofs named as Pitched brick vaulting system built with permanent materials. It marks the change of mosque construction structure from columns to piers. The mosque consists of an internal courtyard, vaulted roof system that consist of elliptical pointed domes and arcades with clay minaret [1].

Oates had stated:

'The earliest definite archaeological evidence of pitched-brick vaulting comes from Mesopotamia in the late 3rd or early 2nd millennium b.c [2].' (Oates, 1970)

Fahraj Mosque is built of sun-dried, unfired clay tiles and mud bricks. Barrel vaults are located in the corridors to the prayer hall. The mosque is considered the first design in Iranian Islamic architecture and heritage. It represents an innovation in Islamic architecture of using pillar that was soon lost to the new innovation of a four-iwan ${ }^{44}$ prototype that was patronized by Seljuks in the eleventh century [3].

[3] Its primitive architectural form and space provided a loose sketch for subsequent designs, based on variations of the prayer hall and courtyard plan, which have effectively served the liturgy of Islam for centuries. Its diverse functions have evolved and fanned out into a variety of specialised structures (Yeomans, 1999). 


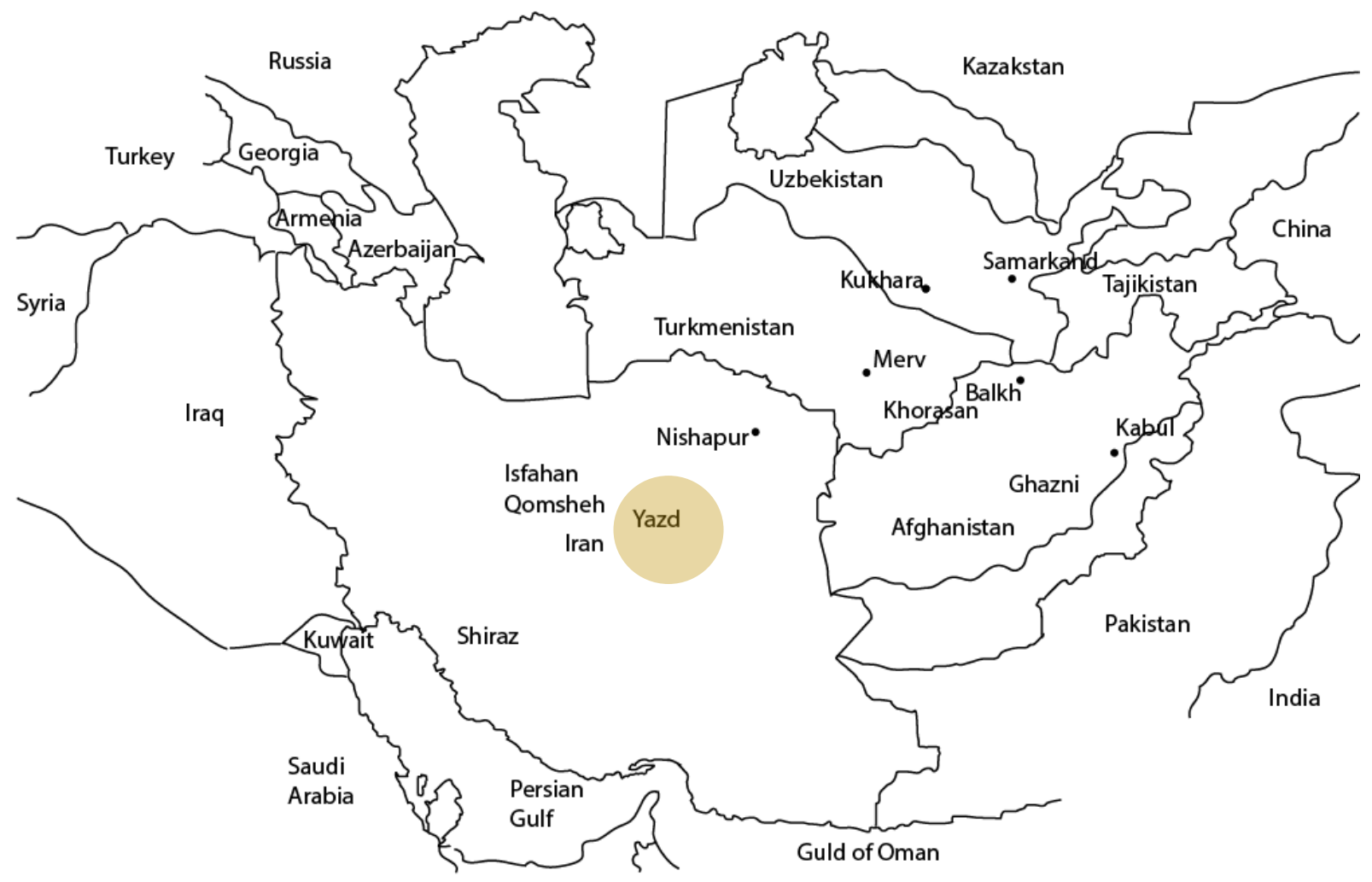

Figure 223: Fahraj Mosque, Yazd, Iran

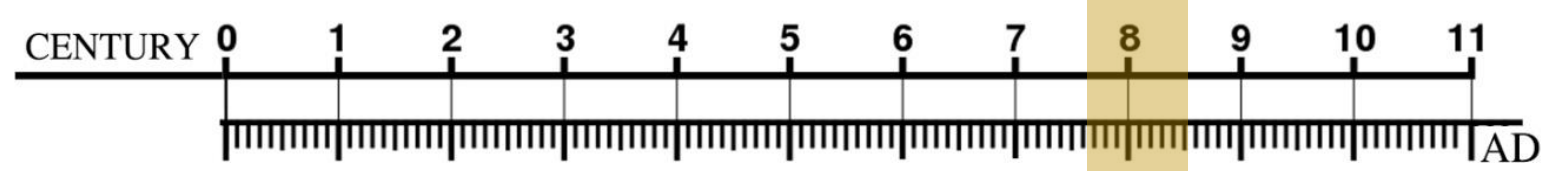

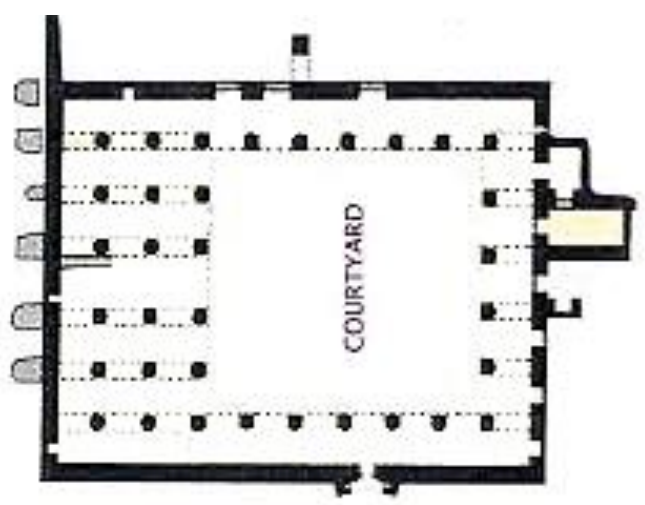

Figure 224: Fahraj Mosque, simple Arab Plan

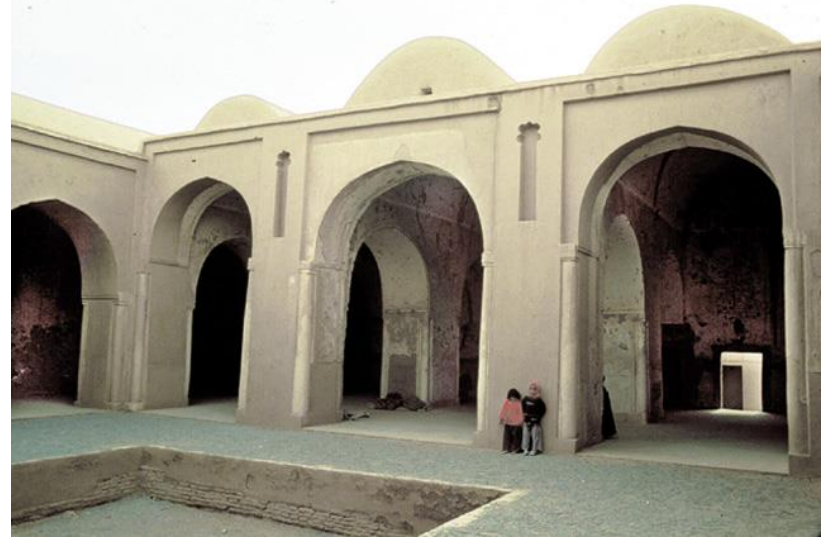

Figure 225: Fahraj Mosque, 750-789AD

Source : Archnet 


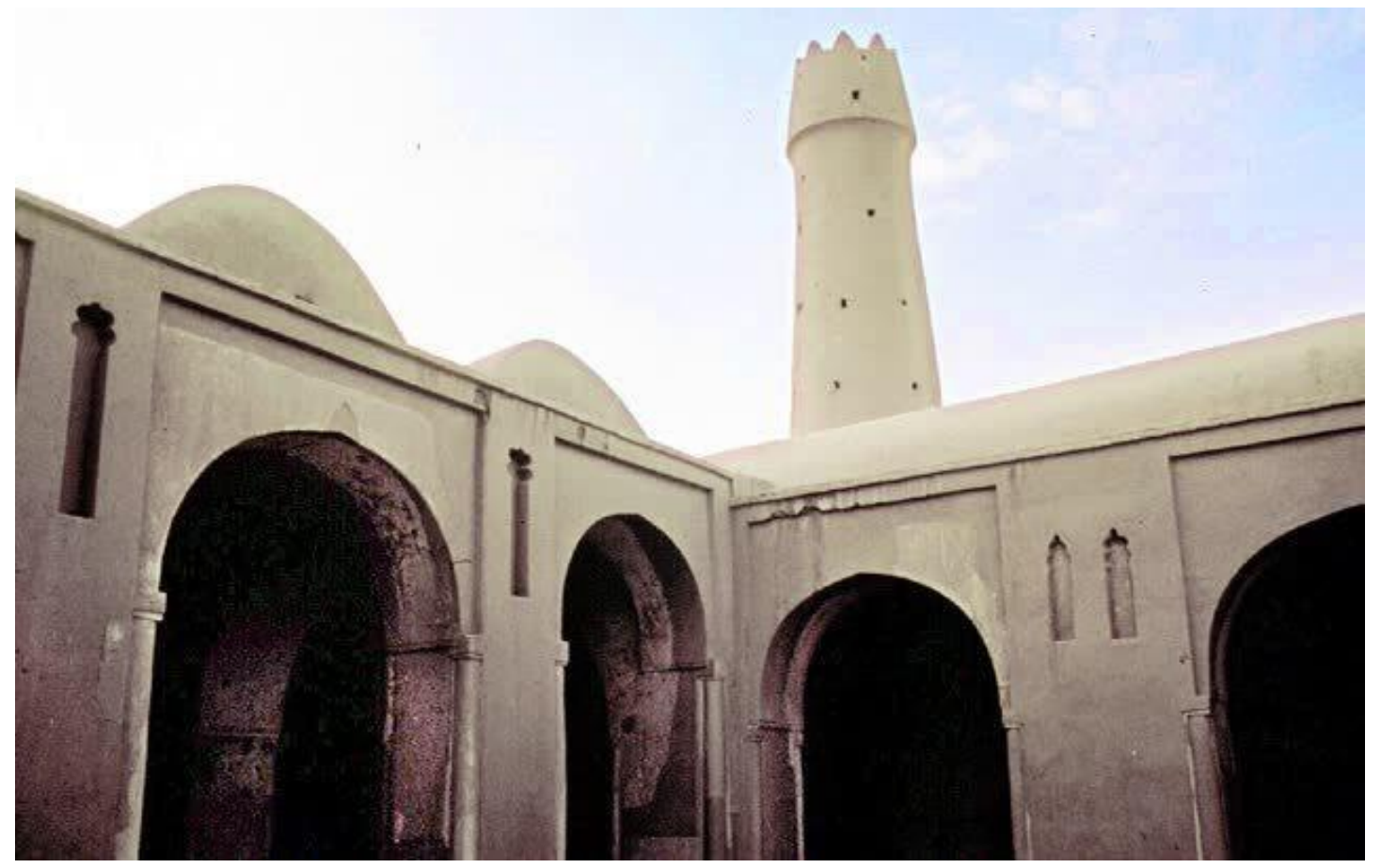

Figure 226: Fahraj Mosque, 750-789AD

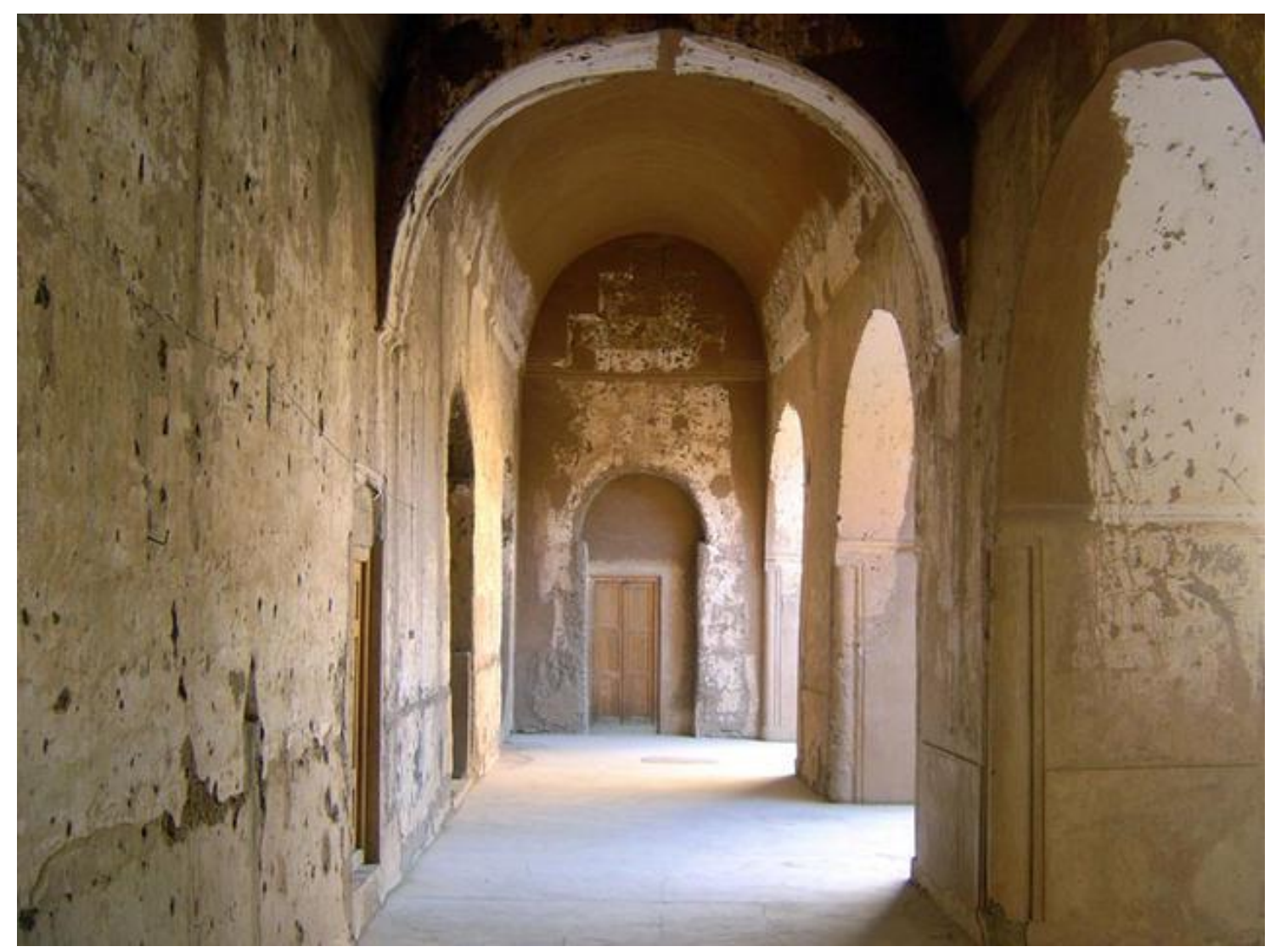

Figure 227: Barrel Vaults in Fahraj Mosque, 750-789AD

Source: Archnet 


\section{b. Tarik Khana Mosque: 750-789AD}

Damghan in Iran

Tarik Khana Mosque is located in Damghan, Semnan Province in Iran. It was built during the Abbasid Period. Tarik Khana ${ }^{45}$ is a simple Arab Hypostyle Plan with Sassanid construction Methods. A covered prayer hall, and two side arcades ${ }^{46}$. The nave leading to the Qibla is wider in width and height in order to highlight the entrance to The Mihrab where the Imam Stands. The mosque payer hall is covered with flatted pitched domes. In Tarik Khana Mosque the piers had been converted into massive thick and heavy columns. This methodology represented an important evolutionary stage in mosque construction innovation

The arcades of the Mosque were built with Sassanid building methods formed of fired bricks, elliptical pointed arches on massive circular brick piers as the elliptical arches and massive columns resembles the Sasanian palaces. Tarik Khana shows the adoption of pre-Islamic techniques for the construction of Arab hypostyle plans [1] [2].

\footnotetext{
${ }^{45}$ House of God

${ }^{46}$ Riwaq
} 


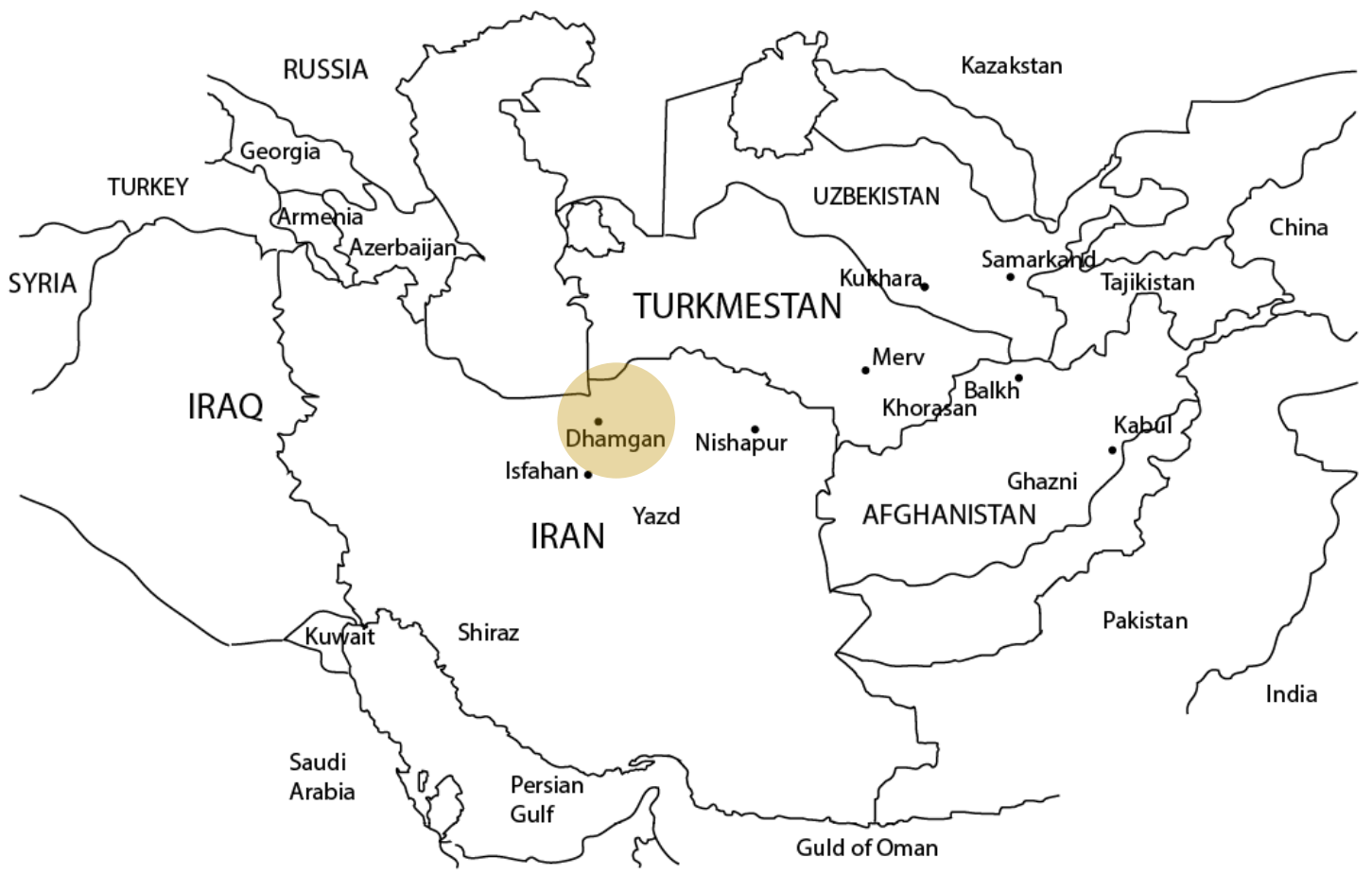

Figure 228: Tarik Khana Mosque, Damghan, Iran
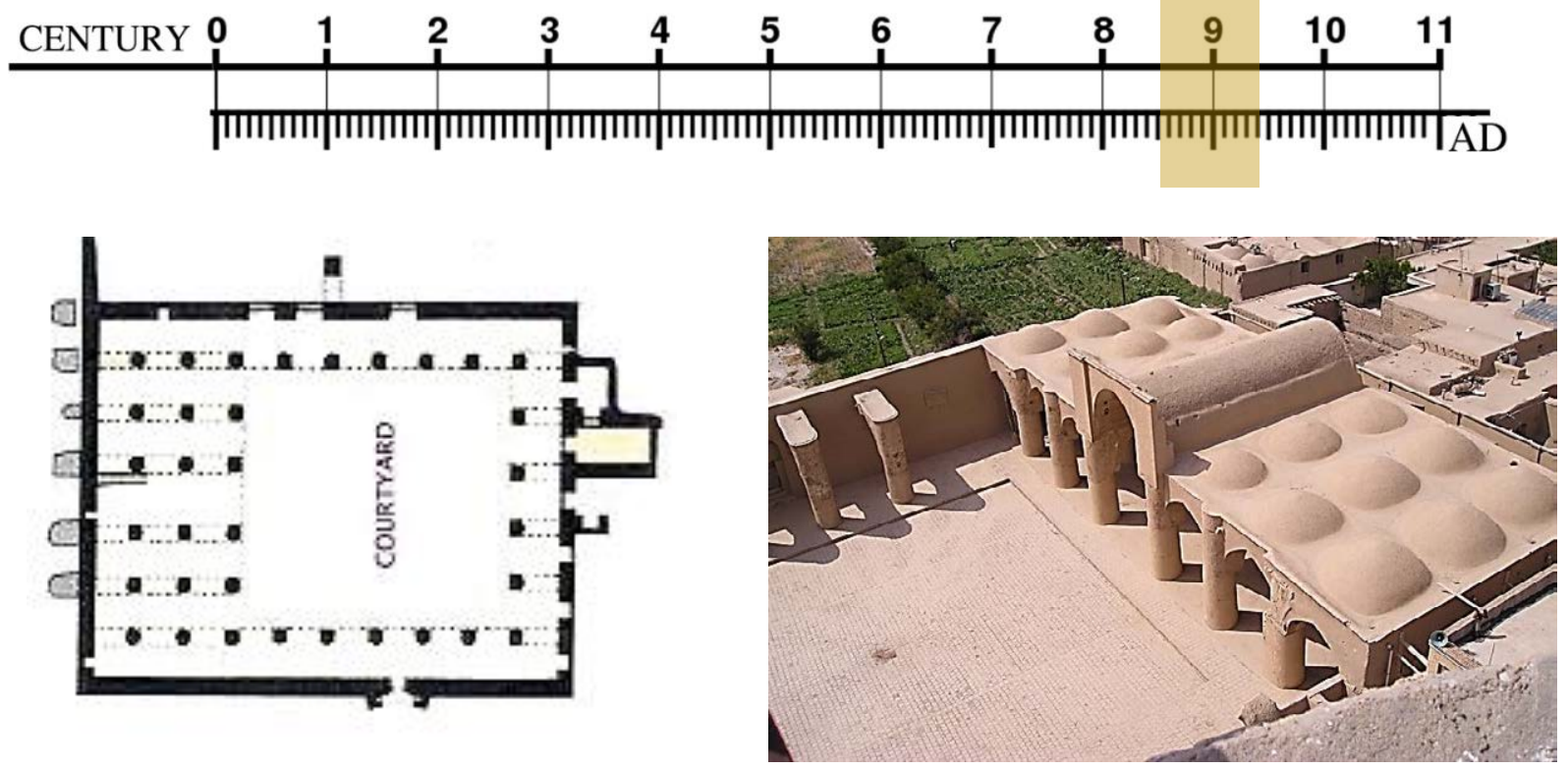

Figure 229: Tarik Khana Mosque simple Arab Plan

Figure 230: Tarik Khana, 750-789AD 


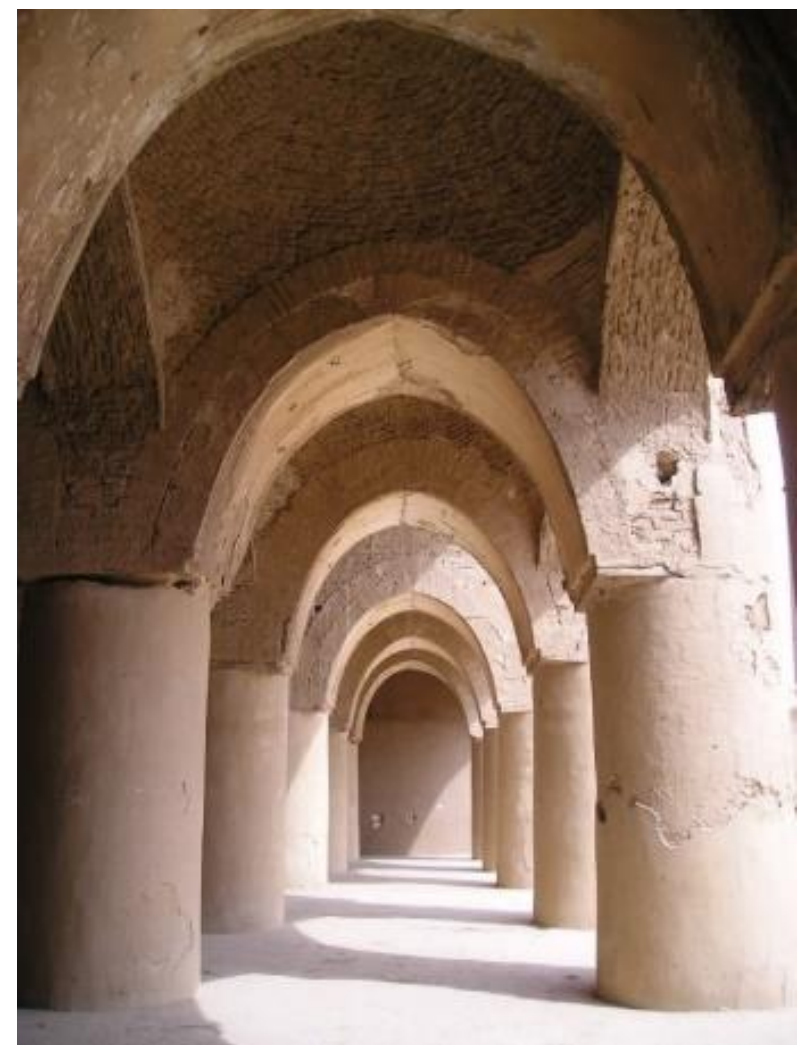

Figure 231: Pitched-brick Vaulting in Tarik Khana

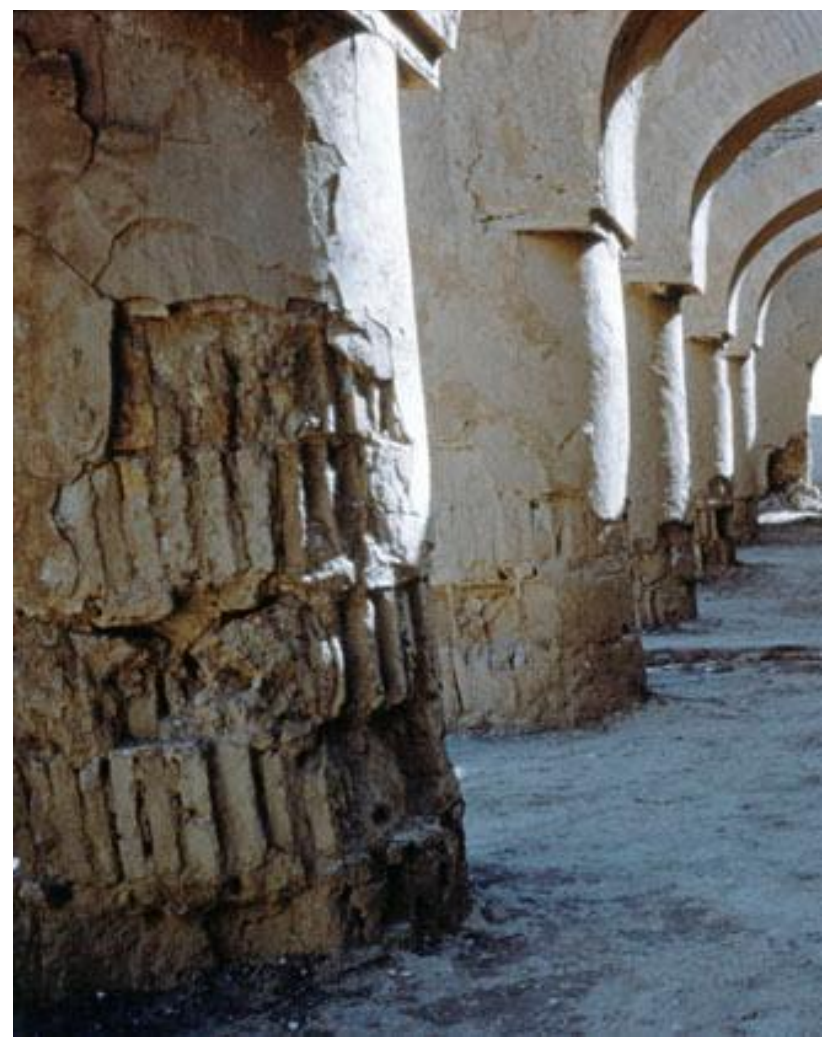

Figure 232: Tarik Khana brick Method

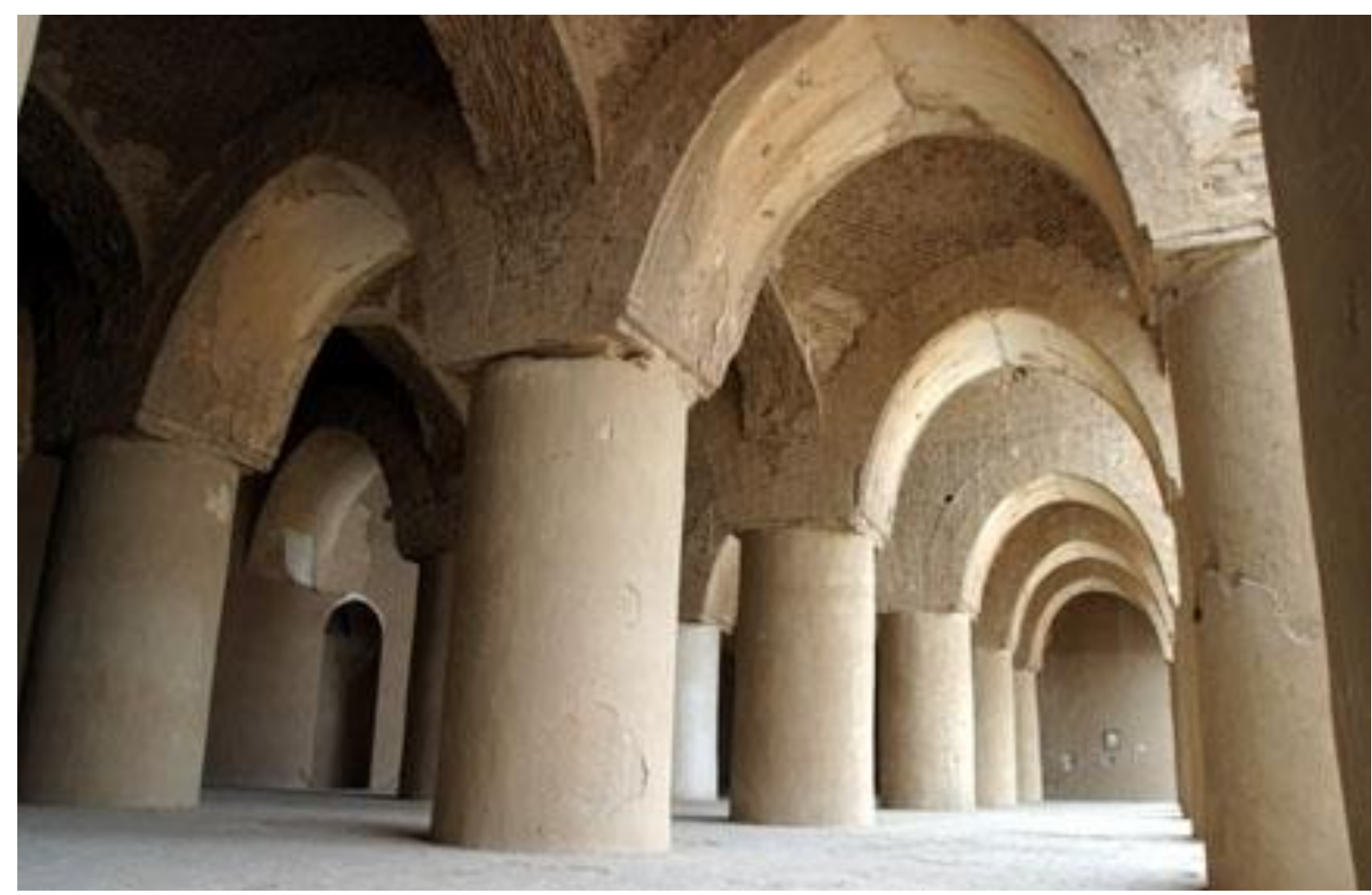

Figure 233: Pitched-brick Vaulting in Tarik Khana, 750-789AD 
Nain Friday mosque is a typical pre-Seljuk mosques with a hypostyle plan. A courtyard is accessed through the arcades that are built from bays of irregular spacing and number. The courtyard facade dates to reconstruction work of Seljuk period but the central nave on the southwestern Qibla side is dated to the original period of construction. The Qibla axis is emphasized by angled piers, and also by the slightly increased width and height of the central nave. A courtyard access through arcades to the prayer hall [Figure 237]. The central nave on the southwestern Qibla side dated to the original period of construction. The Qibla axis is emphasized by slightly increased width and height of the central nave. The minaret represents an important transition from the early square form to the Iranian minarets of the eleventh and twelfth centuries. The transitional form of this minaret, and its relatively unadorned state suggest that it is preSeljuk, contemporary with the oldest areas of the mosque. The Na'in Mosque is renowned for the extensive and masterful carved stucco of the Mihrab and adjacent bays, including the oldest extant epigraphic friezes in Iran. Stylistically it bridges the stucco decoration of the Sasanian and Abbasid periods with that of the Seljuks; effusive vegetal forms released from earlier geometric constraints [1] [2] [3].
[1] (Hillenbrand , 1994)

[2] (O'Kane , 1995)

[3] (Pope, Architectural Ornament, 1977) 


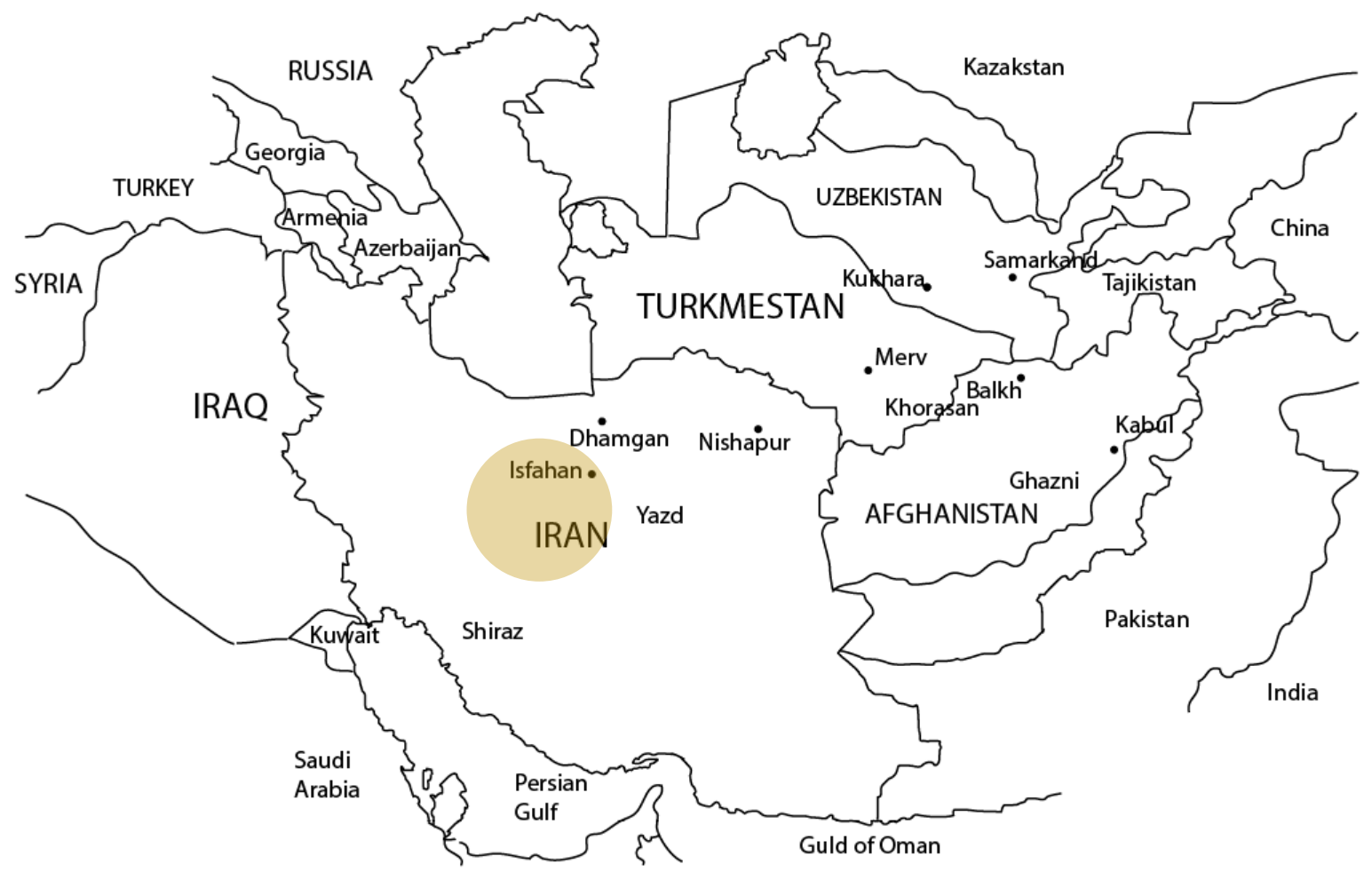

Figure 234: Mosque of Na'in Location Isfahan

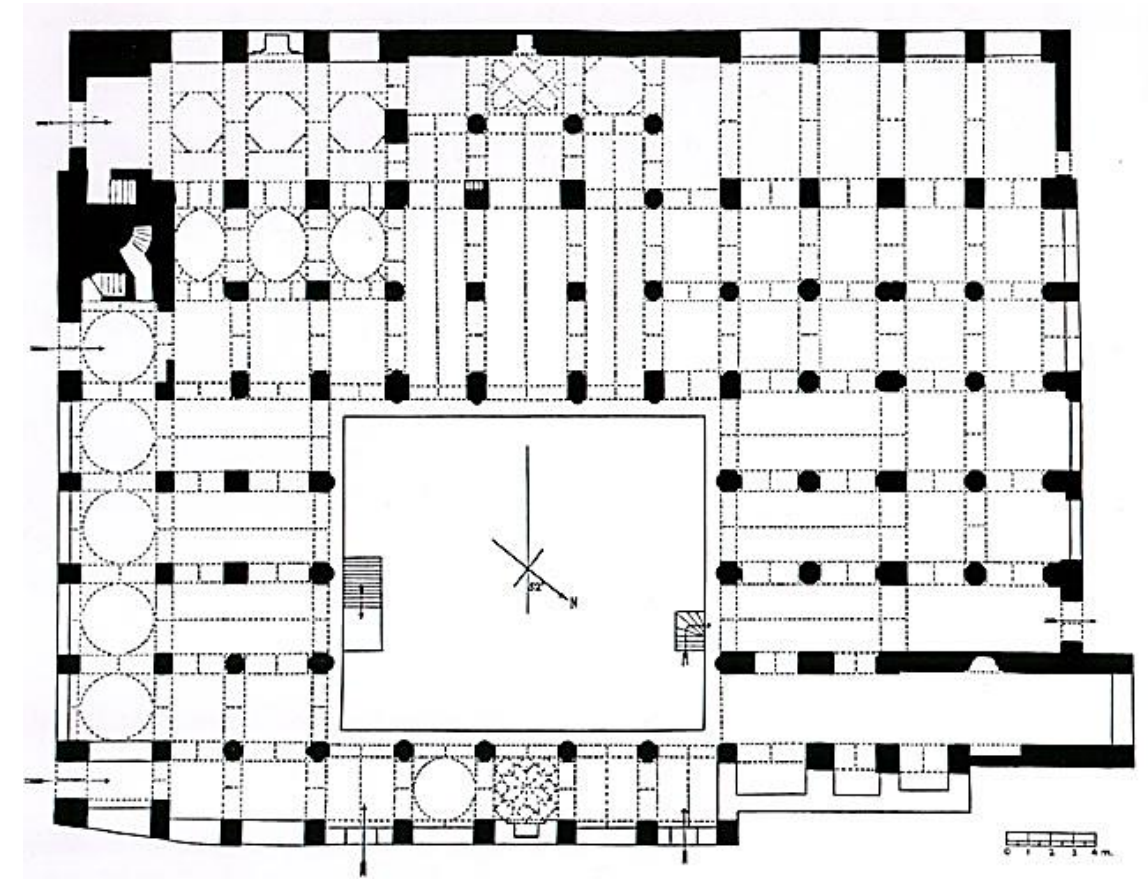

Figure 235: Mosque of Na'in Plan

Source: Archnet 


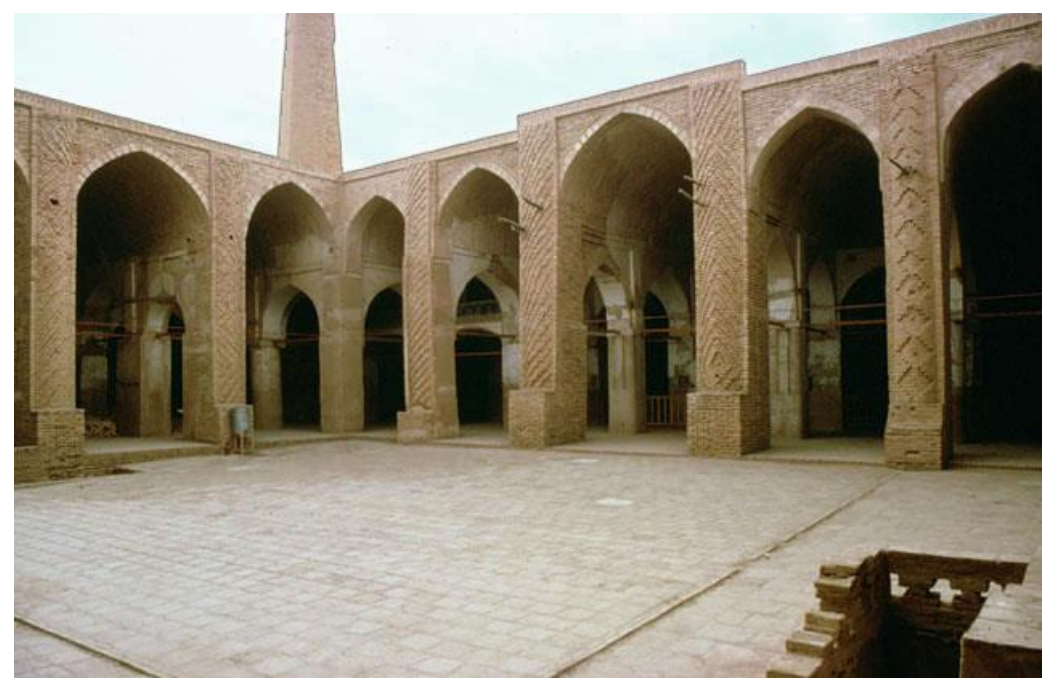

Figure 236: Na'in Pitched Brick Vaults.

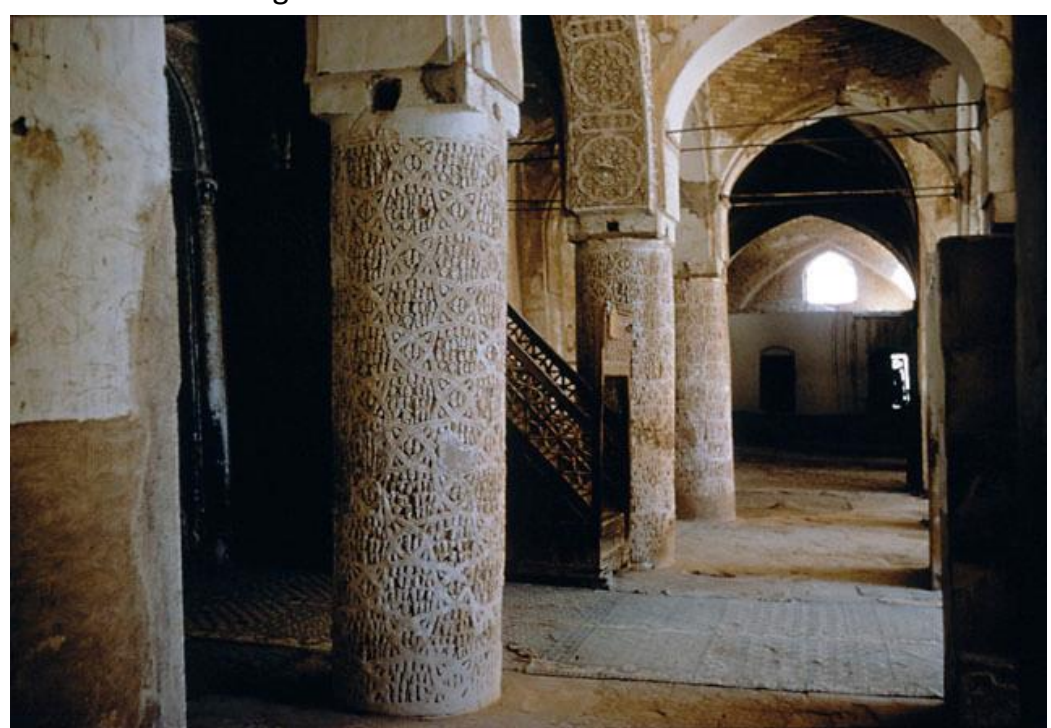

Figure 237: Na'in Pitched Brick Vaults

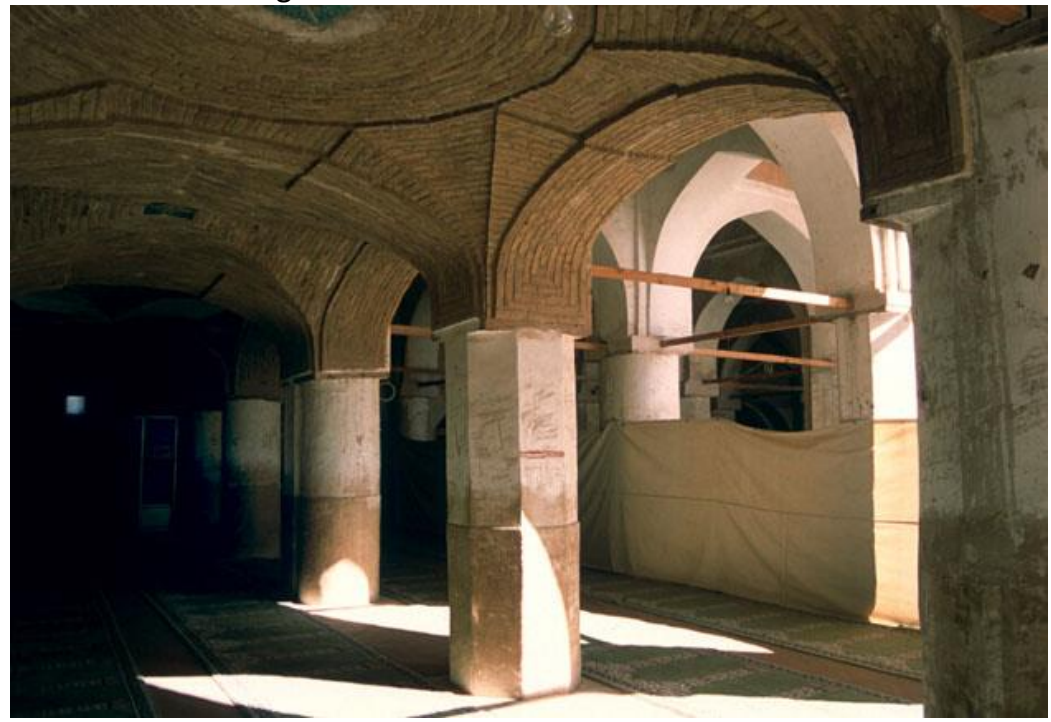

Figure 238: Nain flatted pitched Domes

Source: Archnet 


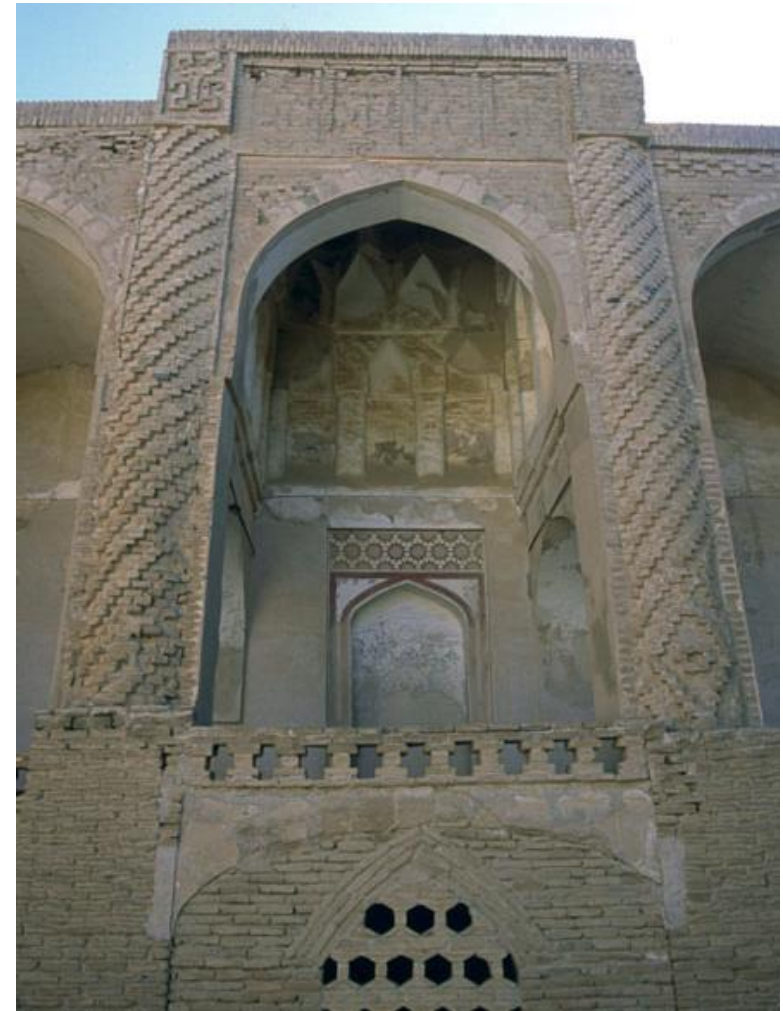

Figure 239: Mosque of Na'in Chamber Hall Dome

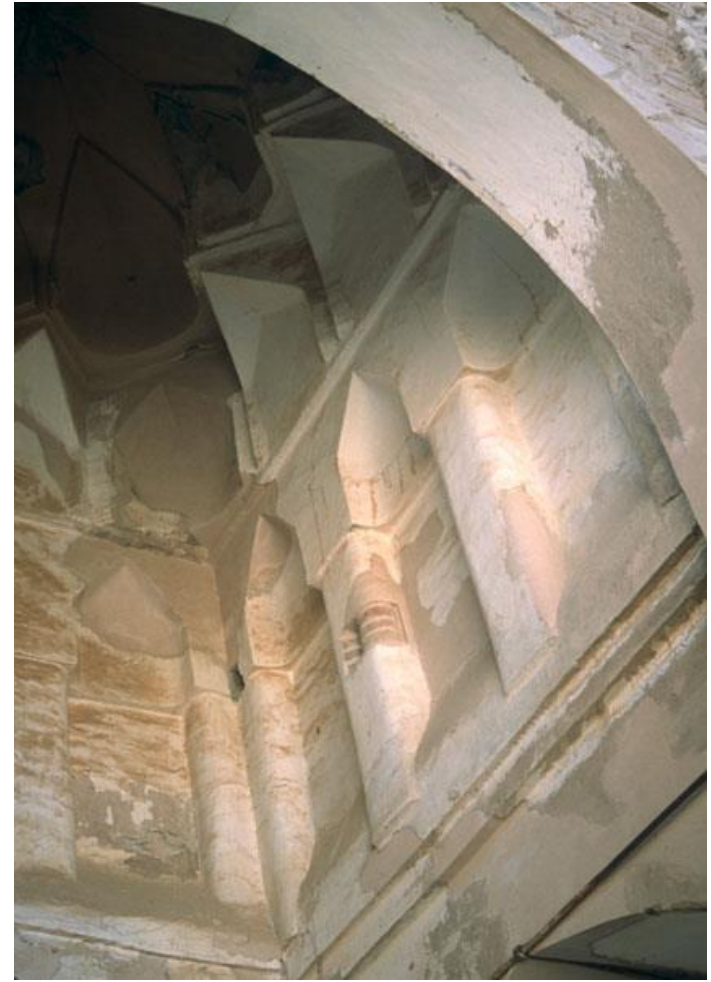

Figure 240: Chamber Hall Vault

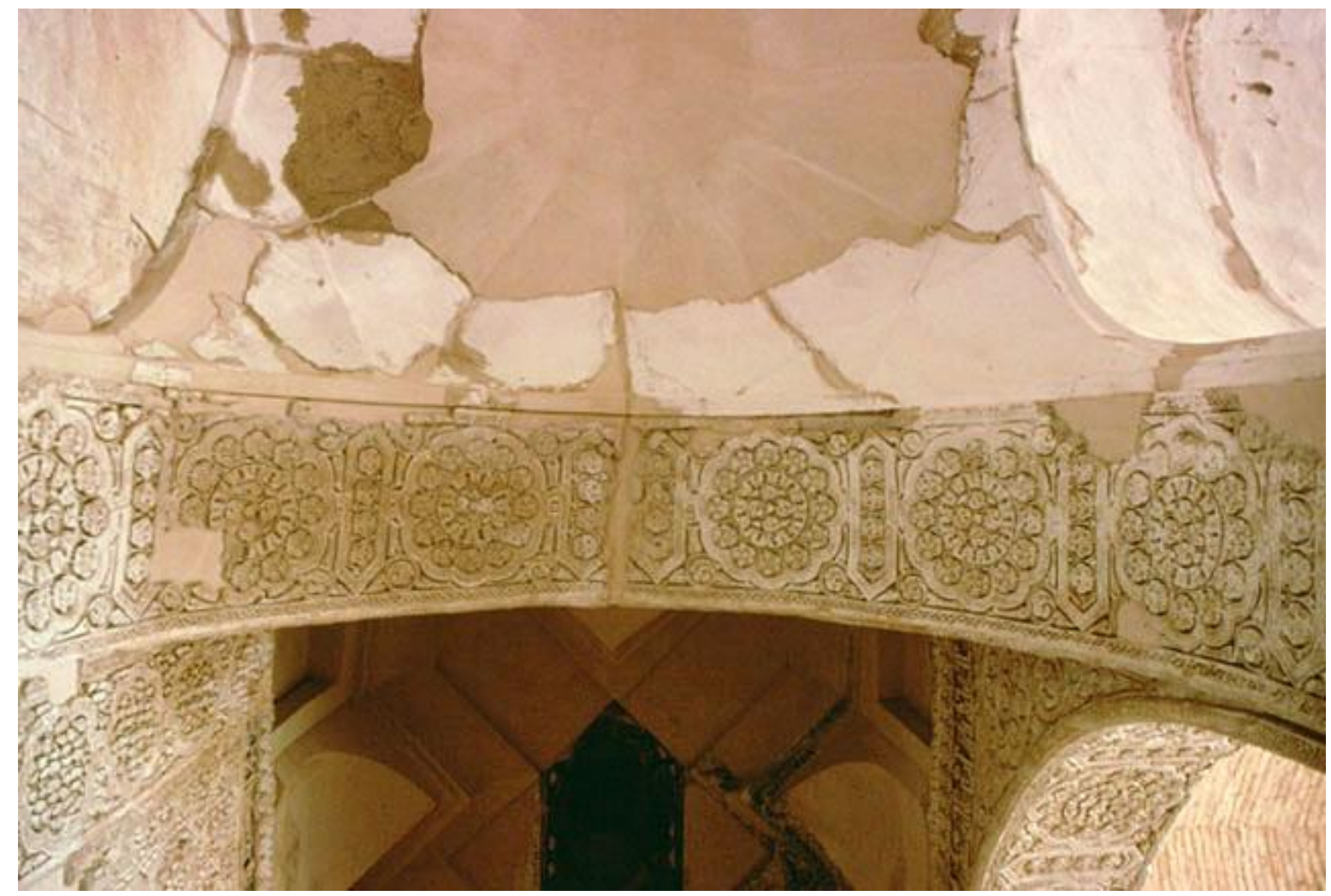

Figure 241: Nain Mihrab Dome

Source: Archnet 


\subsubsection{Buyid: 932-945 AD}

Shiraz in Fars Province in Iran: Shiite

Buyid were Zoroastrian faith but converted to Islam. The Buyid dynasty was Shiite Muslim dynasty, which raised in Iran. The [1] (Hillenbrand , 1994) Buyids ruled during the time gap between Abbasid Arabs and Seljuq Turks. The dynasty was founded by Ali ibn Buya, who conquered Fars in $934 \mathrm{AD}$ and made Shiraz the capital. In 945 $A D$, his youngest brother, Ahmad ibn Buya, conquered Iraq and made Baghdad his capital, receiving the honorific title of, [3] (Pope, Architectural Ornament, 1977)

Mu'izz Al Dawla. The Buyid consciously revived symbols and practices of Sassanid dynasty. At its greatest extent, Buyid encompassed most of Iran, Iraq, Kuwait, and Syria, along with parts of Oman, UAE, Turkey, Afghanistan and Pakistan. During the ninth until the tenth centuries, just prior to the invasion of the Seljuq Turks, Buyids were the most influential dynasty in the Middle East. Under Adud Al Dawla Period, it became one of the most powerful Muslim dynasties. During the period of Buyids and before the Seljuk Empire Na'in Friday mosque was built in 960 AD in Isfahan province [1] [2] [3]. 


\subsection{Afghanistan Introduction}

\subsubsection{No Gumbad Mosque Birth: Nine Domed Mosques}

This is a type of mosque roofed by nine domes of equal size. This was founded as part of Central Asia and East Africa design methods. The earliest extant examples date from the ninth [1] G. R. H. King, The nine bay domed mosque in Islam', Madrider Mitteilungen 30: 1989 century AD. Most nine-domed mosques are fairly small usually 10$15 \mathrm{~m}$ square. It is common for these buildings to be open on two, three or even four sides but it is rare for them to have court or minaret [1]. Sometimes the central row of domes is raised to emphasize the Mihrab axis. There are two theories about the origin of this type of mosque. The older theory originated by [2] (K. A. C. Creswell and James W. Allan, 1989) P. 11-13

[3] (Ettinghausen, 1972) P. 57 Creswell that asserts that the mosque is derived from the earliest forms of Islamic funerary monuments, such as the Qubbat Al Sulaybiyya at Samarra, which were domed and had open sides [2]. Other studies suggested that the type derives from honorific buildings such as Khirbet Al Mafjar. Although the origin of the design may be disputed it is clear that many of the mosques were associated with tombs or burials so that it is reasonable to suggest that they should be regarded as memorial mosques [3]. 


\section{a. Masjid-e Haji Piyada}

No Gumbad ${ }^{47}$ Mosque

Balkh in Afghanistan

The Mosque named as Nine Domes also famed as Khoja Piyada or

[1] (Golombek, 1969)

P. 173-189.

Masjid-e Haji Piyada, which means the Mosque of the Walking Pilgrims. It is dated to early IX Century AD. In is considered one of the

[2] (Hillenbrand, 1994)

P. $78,104,290,410,488$

Early Islamic route monuments identified in Afghanistan. Its modern name, No Gumbad, refers to the nine vaults that cover the original structure, these vaults have since fallen. The mosque is aligned with

Qibla on the northeast-southwest axis. Inside, the prayer hall is divided into nine bays, three rows and three aisles, with triple archways. The arches rest on four thick columns at the center and Pairs of columns but single once at the corners. The northeast wall opposite Qibla opens to the exterior with a triple arcade carried on two additional columns. Three arched openings were pierced into each side wall, while the southwest wall which contains the semidomed Mihrab niche. The mosque was richly decorated on the interior with deeply carved arabesques covering the capitals, imposts, spandrels and soffits of the arcades. No Gumbad Mosque is flanked by a cemetery to its north that was established at least two centuries after its construction [1] [2] [3]. A saint known as Hadji Piyada is buried in the small domed tomb standing immediately before the mosque entrance, giving it the alternative name, Masjidi Hadji Piyade.

'The cubic shape harks back to the Kaaba in Al Masjid Al Haram located in Mecca, and the dome above it represents the heavens [4]. '

[4] (Eurasia, 2016)

\footnotetext{
${ }^{47}$ An Iranian and Mughal term for dome, usually used for a domed tomb
} 


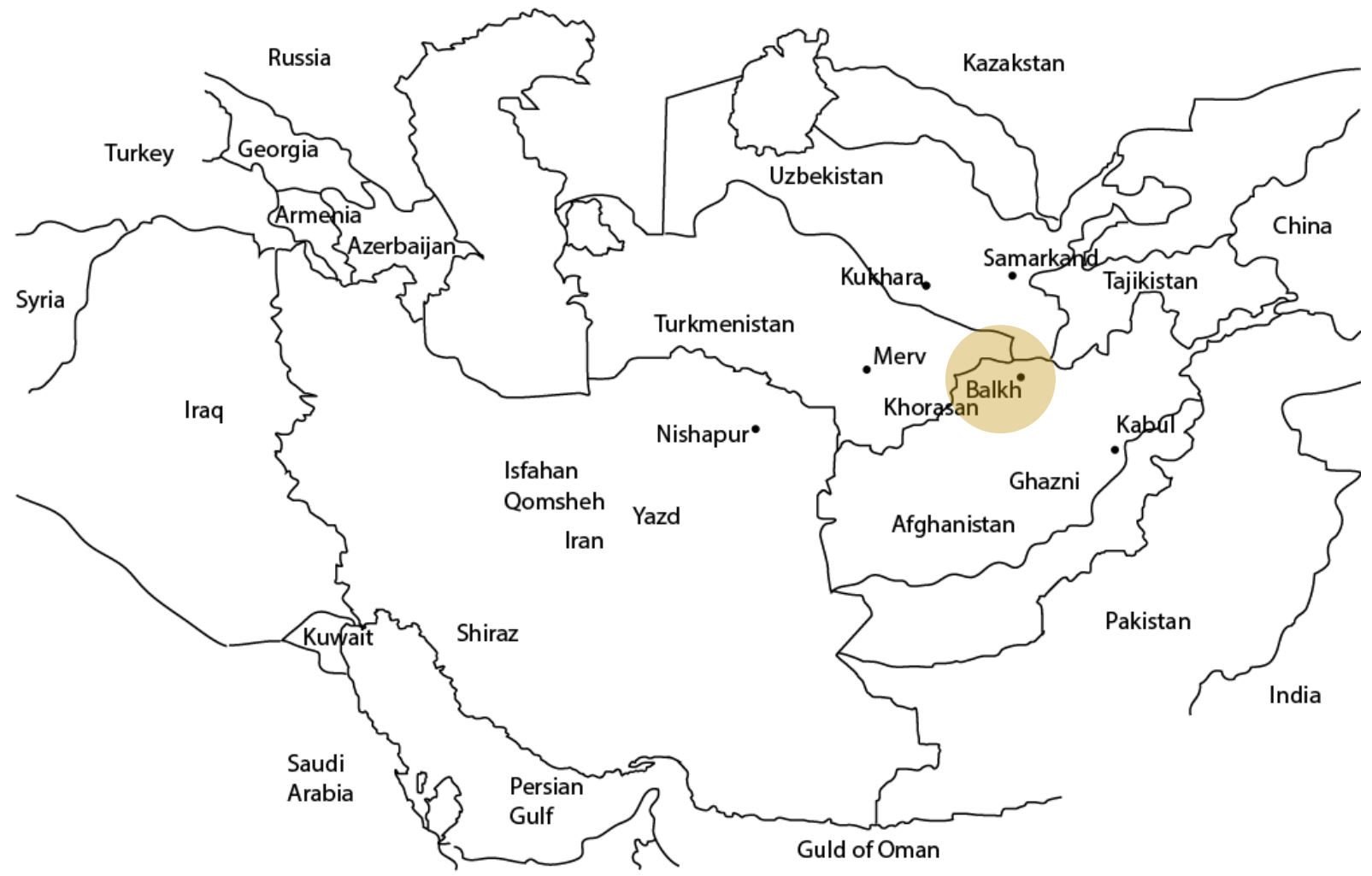

Figure 242: Masjid-e Haji Piyada, No Gumad, Balkh, Afghanistan, 849 AD

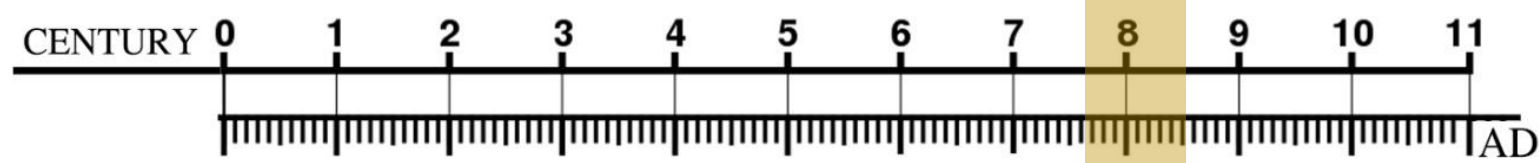

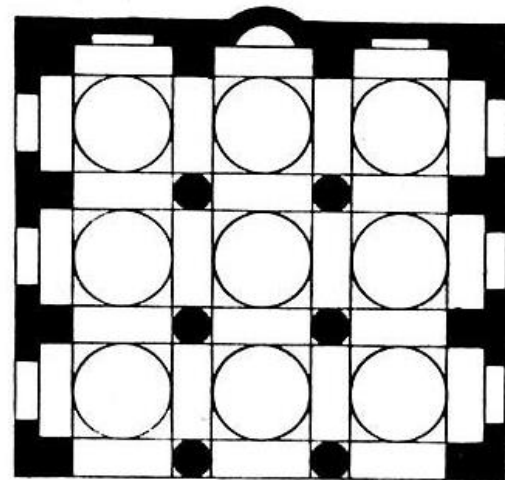

Figure 243: Masjid-e Haji Piyada Plan

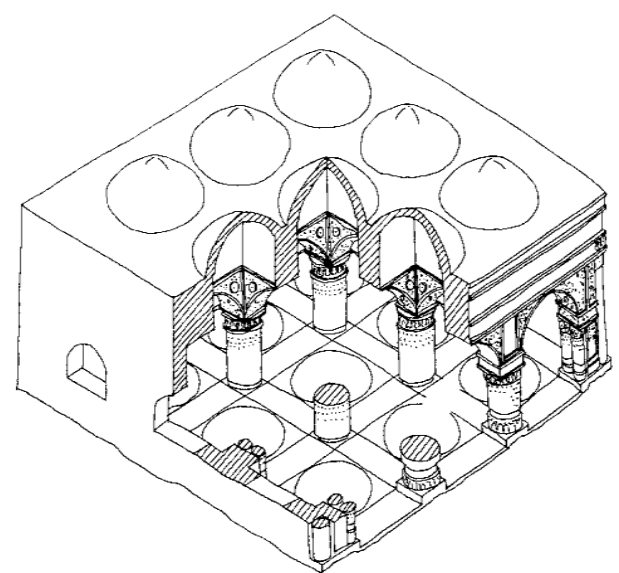

Figure 244: Masjid-e Haji Piyada Prospectiva 
Figure 245: No-Gumad, Balkh, Afghanistan, 849AD

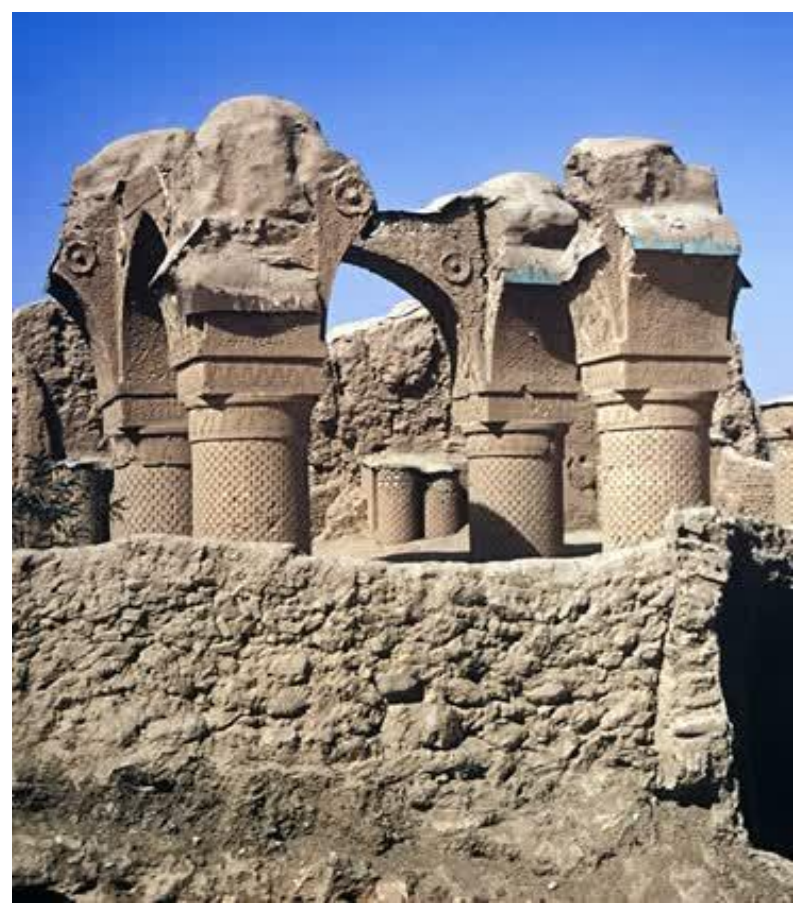

Figure 246: No Gumad, Balkh, Afghanistan, 849AD

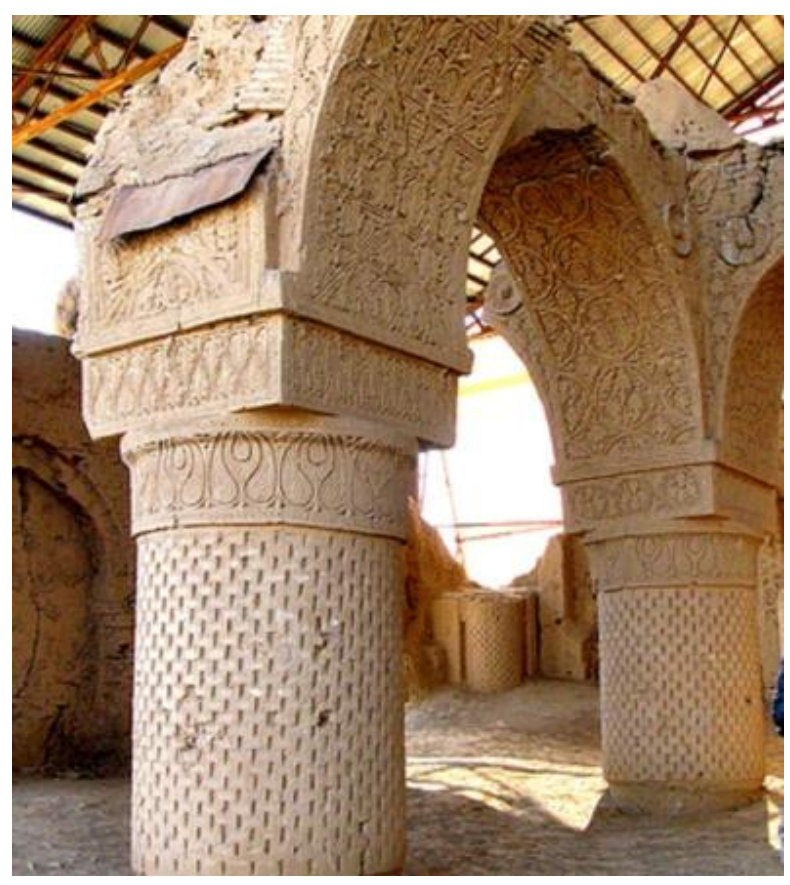

Source: Archent 


\section{Type of Vaults in Central Asia since the Birth of Islam until IX Century}

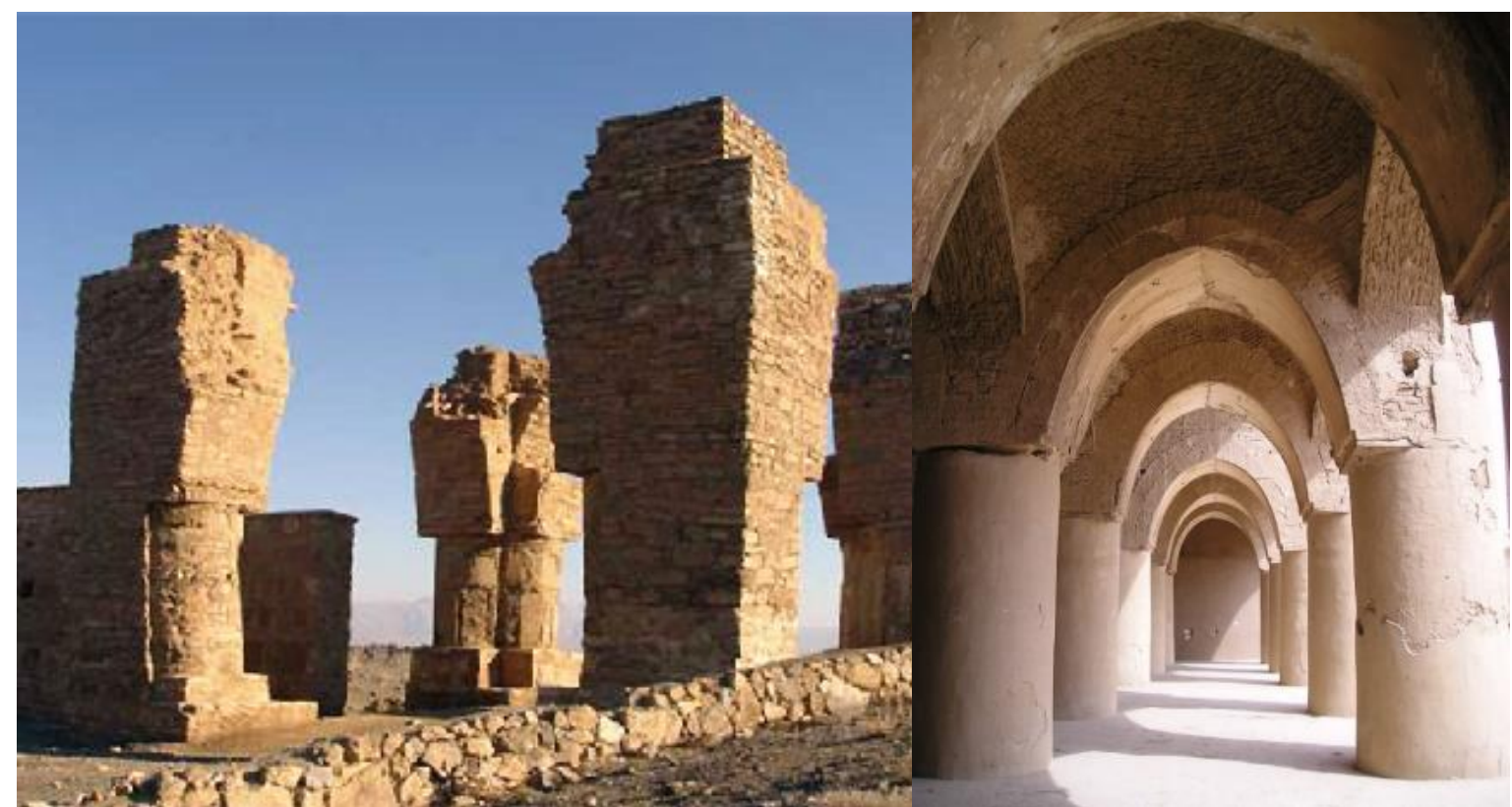

Figure 247: No Gumad prototype

Figure 248: Tarik Khana Vaults , 750-789 AD

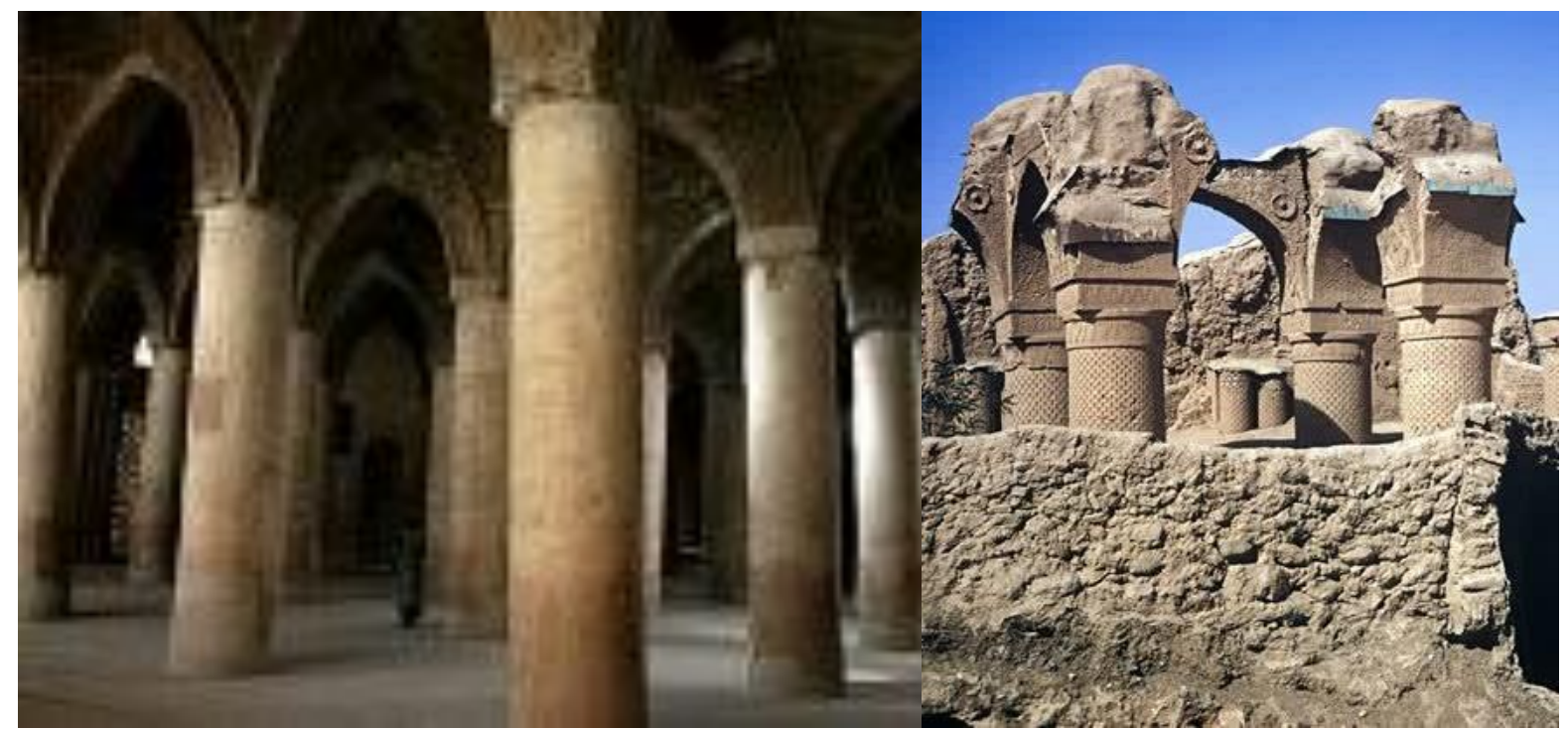

Figure 249: The Great Mosque of Isfahan

Source: Archnet
Figure 250: No Gumad, Afghanistan, 849AD

Source: Wikipedia 


\subsection{Turkmenistan Introduction}

Turkmenistan history divided into two phases: Muslim Arabs $^{48}$ and Oghuz ${ }^{49}$ Turks [1]. The Turkic period was a time of cultural fusion as Islamic traditions brought by the Arabs merged with local Iranian cultures and then were further altered by Turkic invaders and rulers such as the Seljuks, who were Sunni Muslim Empire, originating from the Qynyq branch of Oghuz Turks. Central Asia came under Arab control after a series of invasions in the late seventh and early eighth centuries and was incorporated into Islamic Caliphate. The Arab conquest brought Islamic religion to all of the peoples of central Asia. The city of Merv was constituted as the capital of Khorasan. Merv had political spotlight in 748 AD when Abu Muslim declared a new Abbasid dynasty at Merv, and set out from the city to conquer Iran and Iraq and establish a new capital at Baghdad. Between 821 and 873 AD Turkmenistan was ruled by Tahirids. In 873 AD, Arab rule in Central Asia came to an end after Saffarid conquest. Merv, Samarkand and Bukhara, had the great schools of learning and the celebrated historian. Merv produced a number of scholars in various branches of knowledge. But Saffarid rule was brief and they were defeated by Samanids in 901 AD. Samanids weaked after second half of tenth century and Ghaznavids ruled Turkmenistan in 990s. But, they challenged with Seljuks, which took the rule in 1041 AD [1] [2] [3] [4].
[1] Turkmenistan is a country in Central Asia, bordered by Kazakhstan to the northwest, Uzbekistan to the north and east, Afghanistan to the southeast, Iran to the south and southwest, and the Caspian Seato the west.

[2] (Fischer, 1978)

P. 305-307, 413.

[3] (Hopkirk, 1992)

P. 565.

[4] (Glenn E., 1996)

48 Ethnic groups in the Middle East

49 Common Turkic word for tribe 


\subsection{Transoxiana Introduction}

Transoxiana is the part of Central Asia corresponding to Uzbekistan, Tajikistan, southern Kyrgyzstan and southwest Kazakhstan. People settled on the territory of Uzbekistan centuries ago and built Samarkand, Bukhara and Khiva. Thes lands were crossroad of the Great Silk Road connecting Asia and Europe. The Numerous bazaars and workshops craftsmen created fine works of art, which by the Silk Road reached the most remote parts of Europe and Asia [1].

[1] (Adventure, 2001).

During, the first five centuries of Muslim Civilization era, between 622 until 1106 AD, major trends of Islamic monumental architecture had developed. These innovations came from the region between Iraq until Central Asia. The Samanid mausoleums were major evolution in Architecture during the period [2].

[2] (Blair, 1991)

P. $37-38$

\subsubsection{Samanid: 819-999 AD}

A Sunni Persian domain established as semi-independent dynasty ruled over Transoxiana and Khorasan during the Abbasid period. Samanid were the first Persian dynasty to arise after the Arab conquest. Originally, they are High nobility of Sasanian and Parthian Empires. According to historians, the founder of Samanid dynasty, Ismail Samanid, had built a mausoleum for his father but it later became the family burialvault of others Samanid and himself who was died in 907 AD. The Samanid mausoleum located in the city of Bukhara in Uzbekistan and completed in 905 AD [3].

[3] (O'Kane , 1995) 


\section{a. Isma'il Samanid Mausoleum: 914 AD}

Bukhara in Uzbekistan

Isma'il Samanid mausoleum is recognized as a masterpiece architecture for the perfection of its geometric forms. This mausoleum is considered one of the most ancient buildings built of burnt bricks in Central Asia. The Samanid mausoleum is located in Bukhara, Uzbekistan [1]. This Mausoleum was the cultural birth of Samanid dynasty's Architecture, which established during 875 AD [1]. Isma'il ibn Ahmad, was the Samanid Emir of Transoxiana during 892 until 907 AD then Khorasan from 900 to $907 A D$, who built the Samanid mausoleum for his father, then became the family burial Mausoleum. The mausoleum is a square chamber with a hemispherical dome and decorative brickwork on both exterior and interior. The dome of the mausoleum rests on arched squinches with grilled openings to provide light to the interior. Particular emphasize was given to the zone transition between the square walls and the round base of the dome. The interior of the squinch arch carries no load, builder display their inventiveness by piercing it with window and decorating the area with elaborate brick patterns. This tendency to break up the squinch into smaller parts eventually culminated into muqarnas designs [2] [3]. The construction of the building is 10.8 metre cube with four identical facades built by Nasr ibn Ismail in 914 AD.
[1] Bukhara Oasis city located in Uzbekistan, Central Asia in a valley west of Samarkand. The first Arab raid on Bukhara occurred in 674 AD although it was not finally conquered until 739AD. During the $\mathrm{IX}$ and $\mathrm{X}$ centuries the city was under the rule of the Samanid and from $900 A D$ was capital of the province of Khorasan. During this period the city flourished and became established as one of the greatest centres of learning in the Islamic world.

[1] (Grabar O. , 1966)

P. 7-46

[2] (Hill, 1964) P. 49.

[3] (Michell, 1995) 
George Michell in Architecture of the Islamic World - Its History and Social Meaning mentioned:

'Square canopy tomb is the earliest Islamic [1] [3] (Michell, 1978) monument in Central Asia. It exhibits especially the unique architecture solution in supporting the dome of the Mausoleum. [1]

And Added:

'Cahartaq design was revolutionary for the time and came to dominate numerous subsequent memorial tombs in Transoxiana'. (Michell, 1978)

The technology of erecting large parabolic arches or domes over square bases was a Parthians architectural influence that spreaded to Khorasan.

And explained:

'The Romans only knew how to erect copulas on circular tambours. The "Iranian" cupola using spherical Pendentives reached Byzantium in the 6th century (Hagia Sofia) and Western Europe only in the Renaissance.' [3]

This Samanid Mausoleum in Transoxiana was the first to have squinches that create a regular octagon as a base for the dome, which then became an Islamic practice in building. Idem in his research paper: Iran in the Ancient East mentioned:

'Free-standing domed pavilions are known from Shiraz and Bukhara in the X century' [2].

[2] (Idem, 1975)

Samanid promoted art giving rise to the advancement of science, literature and attracted scholars such as Rudaki, Ferdowsi, and Avicenna. While under Samanid control, Bukhara was a rival to Baghdad in its glory. Scholars note that Samanid revived Persian more than the Buyids and the Saffarids, while continuing to patronize Arabic to a smaller degree [3] 


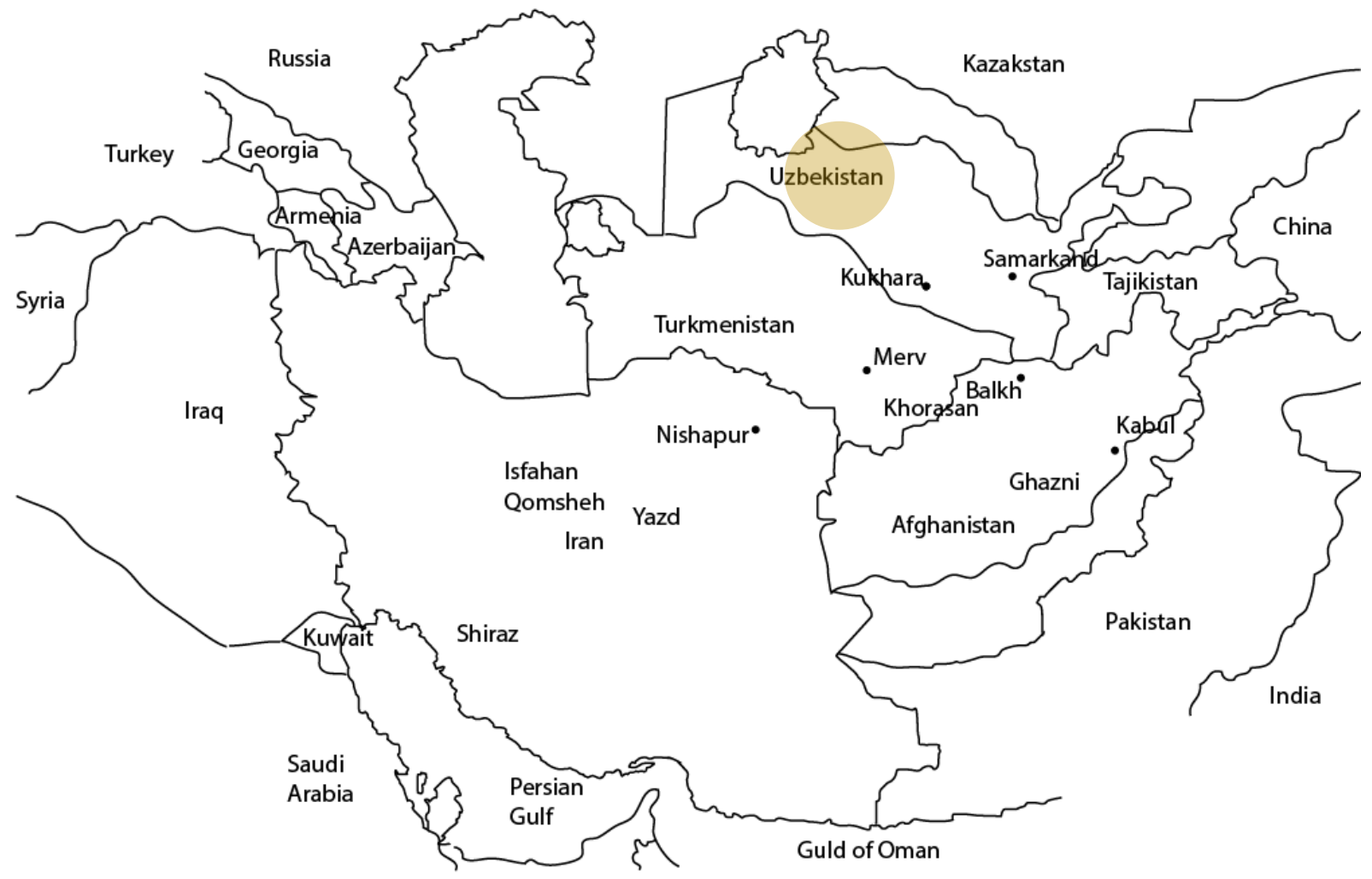

Figure 251: Samanid Dynasty

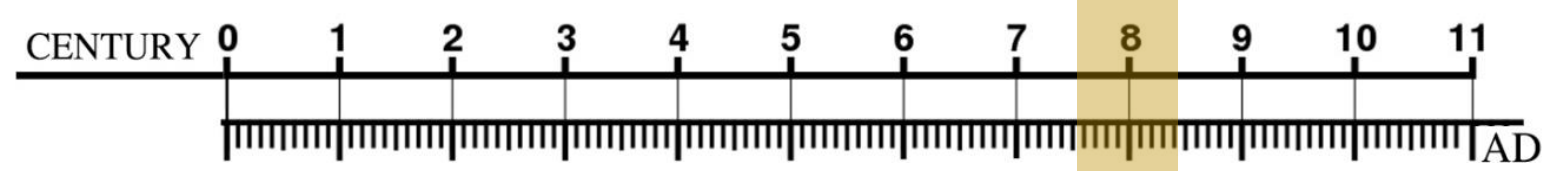

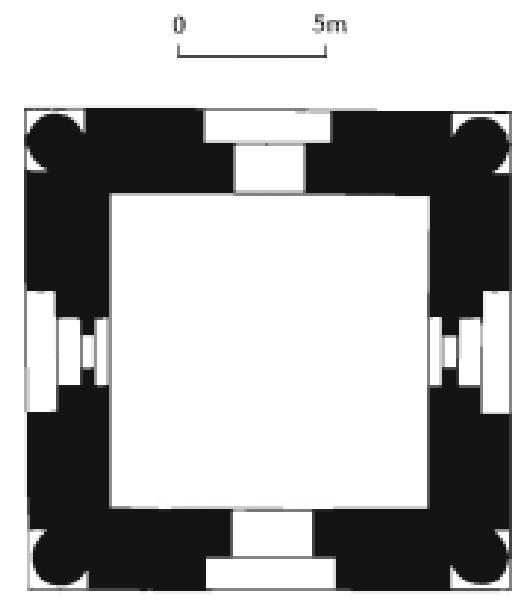

Figure 252: Plan of Samanid Mausoleum

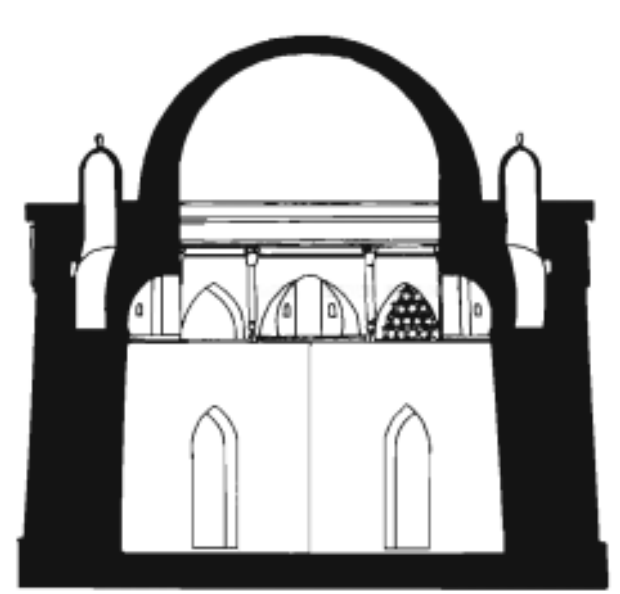

Figure 253: Isma'il Samanid mausoleum Section Source: Tenth-century tomb of the Samanid, Bukhara, Uzbekistan (after Creswell) 


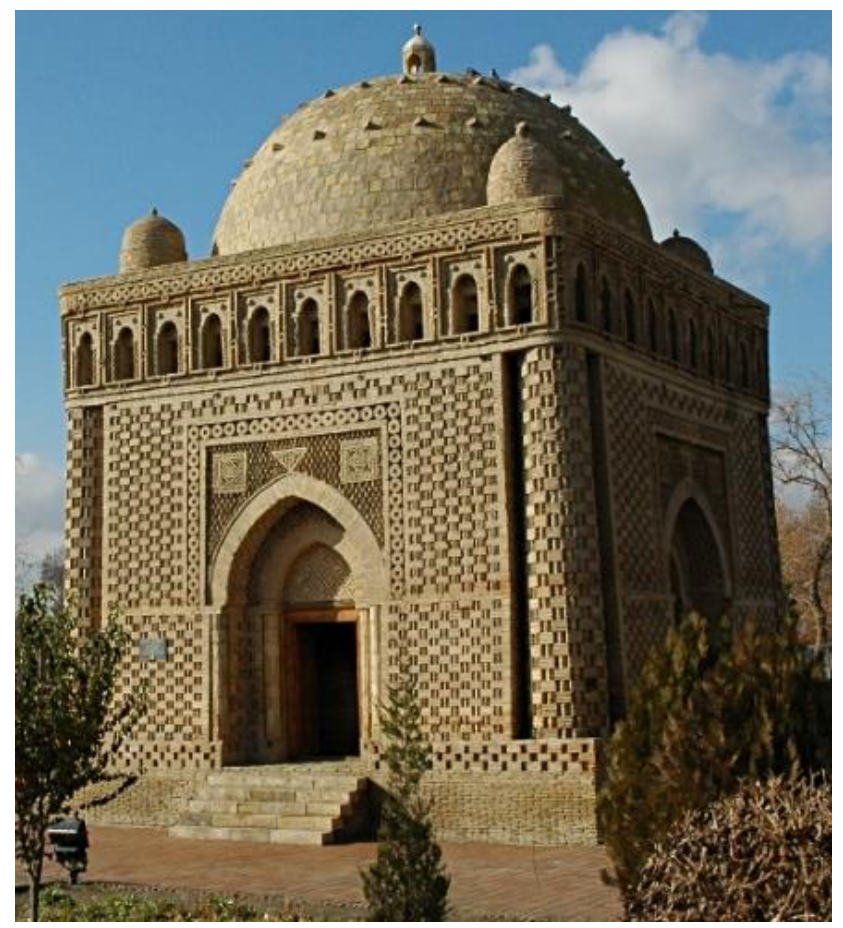

Figure 254: Isma'il Samani mausoleum Bukhara, Uzbekistan

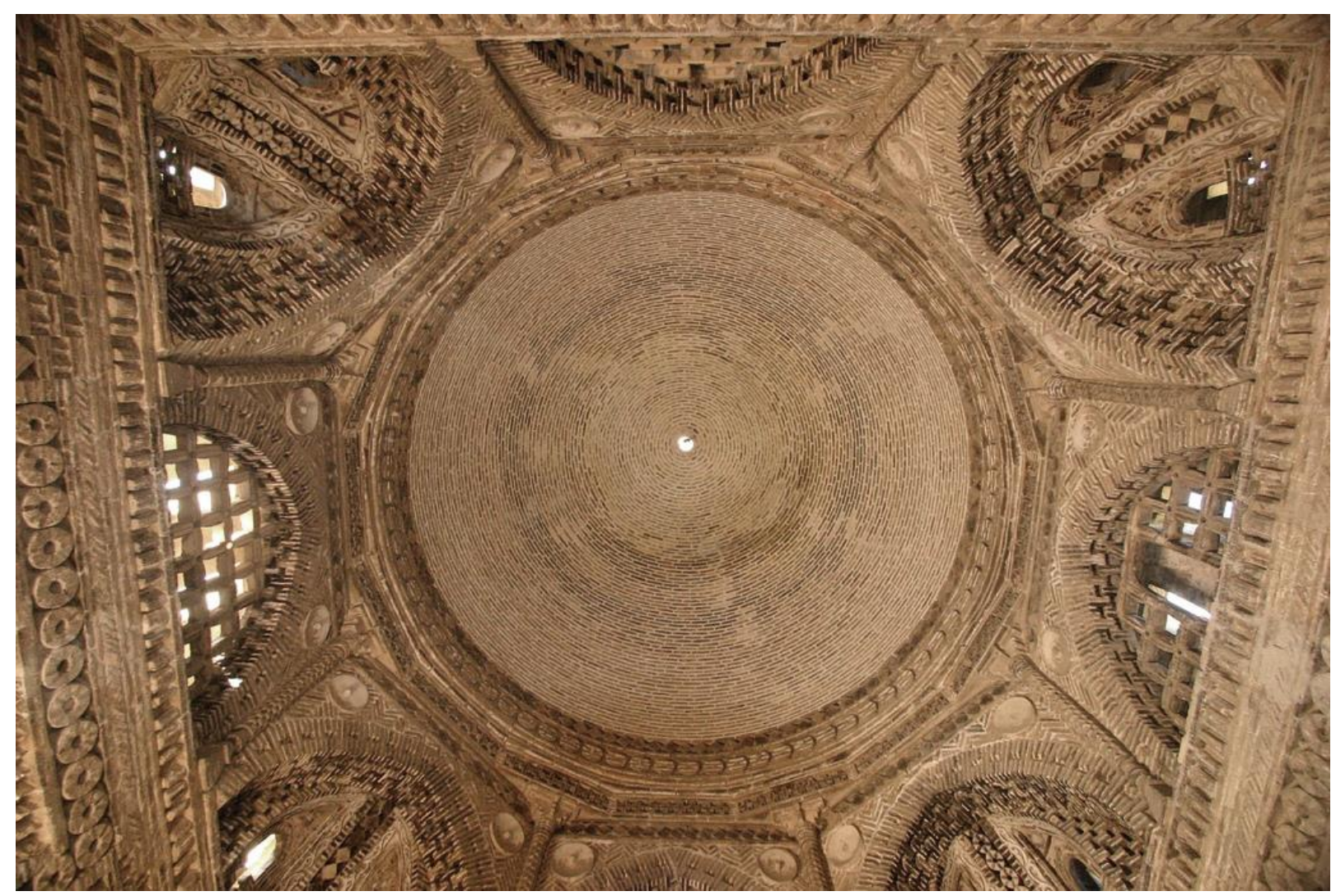

Figure 255: Isma'il Samani mausoleum interior dome Birth Method

Source: Traveler.uz 


\subsubsection{Ghaznavid: 961-1187 AD}

Ghazna

Dynasty of Turkic origin that ruled in Khorasan in: North-eastern Iran, Afghanistan, and northern India. As the Samanid dynasty weakened, Sebuktigin a former Turkic slave had expanded his domains to the Indian border. In 977 AD, he was recognized by Samanids as governor of Ghazna in Afghanistan. Later, His son Mahmoud who had ruled during 998-1030 AD continued the expansionist policy but in 1030 AD, Mahmud Ghazni died, and the Ghaznavid dynasty began to fall apart after his death [1] [2].

\section{a. Arslan Jadhib: Ghaznavid 997AD}

Arslan Jadhib masulem is a symmetrical building. The transition zone between the square mass of the main volume and the dome, set back from the face of the lower section, approximates an octagon with chamfers on the north and west sides. The dome was constructed with thicker course of bricks at the base. The interior zone of transition is octagon, each side had a pointed arch, which is not common in Iran. Some arches had an opening and some are fill with geometric brickwork. The interior of the dome displays brickwork laid to form geometrical patterns. A spiral staircase inside the trunk led to the balcony at top, of which only the muqarnas supports have remained. The trunk of the minaret is surfaced with the simple geometry of brick in plain bond, terminating in an inscriptive band.

The interior of the dome displays brickwork laid in a vibrant herringbone pattern; this may have originally been covered by an ornamental surface [3] [4].

[3] ((The Editors of Encyclopædia, 2016)

[4] (Iran Chamber society, 2016) 


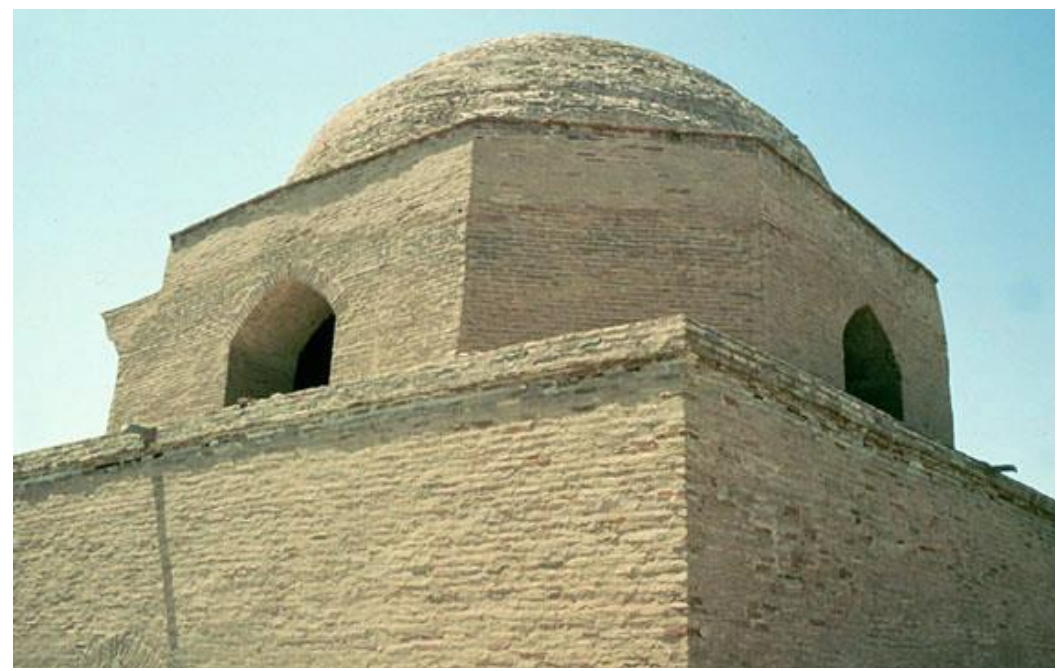

Figure 256: Ghaznavid Mausoleums

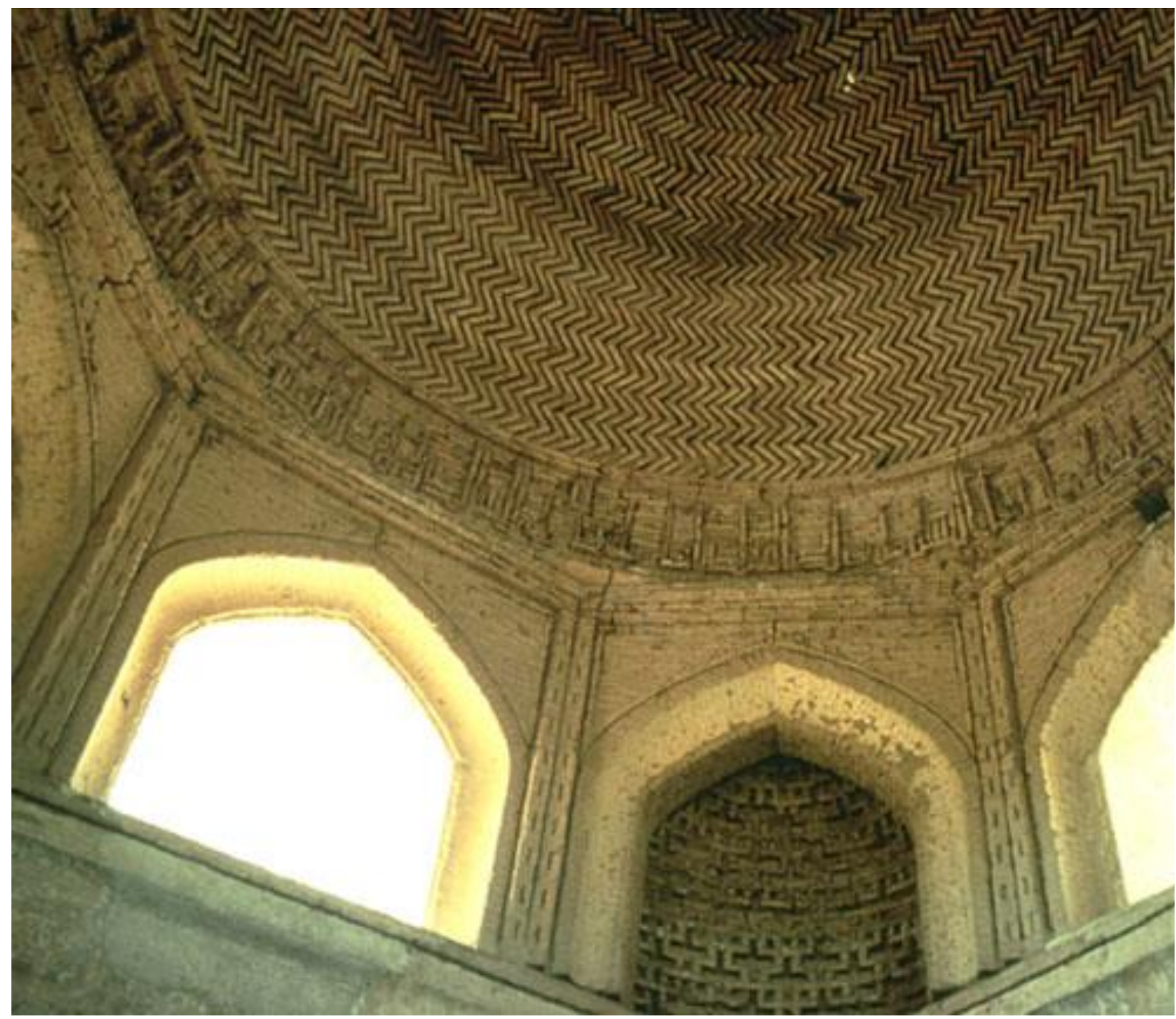

Figure 257: Arslan Jadhib of Ghaznavid Sultan Mahmud Dome Source: Archnet 


\section{a. Mane Baba Mausoleums: 1049 AD}

Ashgabat in Turkmenistan

Abu Sa'eed ibn Abi Al Khair Maihani or Meyheny tomb famed as

[1] Ashgabat is the capital and the largest city Mausoleum of Mane Baba, located in Ashgabat in a small village named Mane in the Kahka region of Turkmenistan [1]. It was built during the reign of the Seljuk Empire between the eleventh and of Turkmenistan in Central Asia twelfth centuries. This mausoleum was constructed over the grave of the famous follower of Sufism and great philosopher of Eastern literature, Abu Said Maneyi, who lived from 968-1049 AD. Abu Sa'eed ibn Abi Al Khair Maihani, was a famous Persian and Leonard Harrow, 1978 ).

Sufi and poet who contributed extensively to the evolution of Sufi tradition. He is considered one of the most influential medieval Sufi of Central Asia [2] [3].

[3] (Pope, Arthur Upham, 1977). 


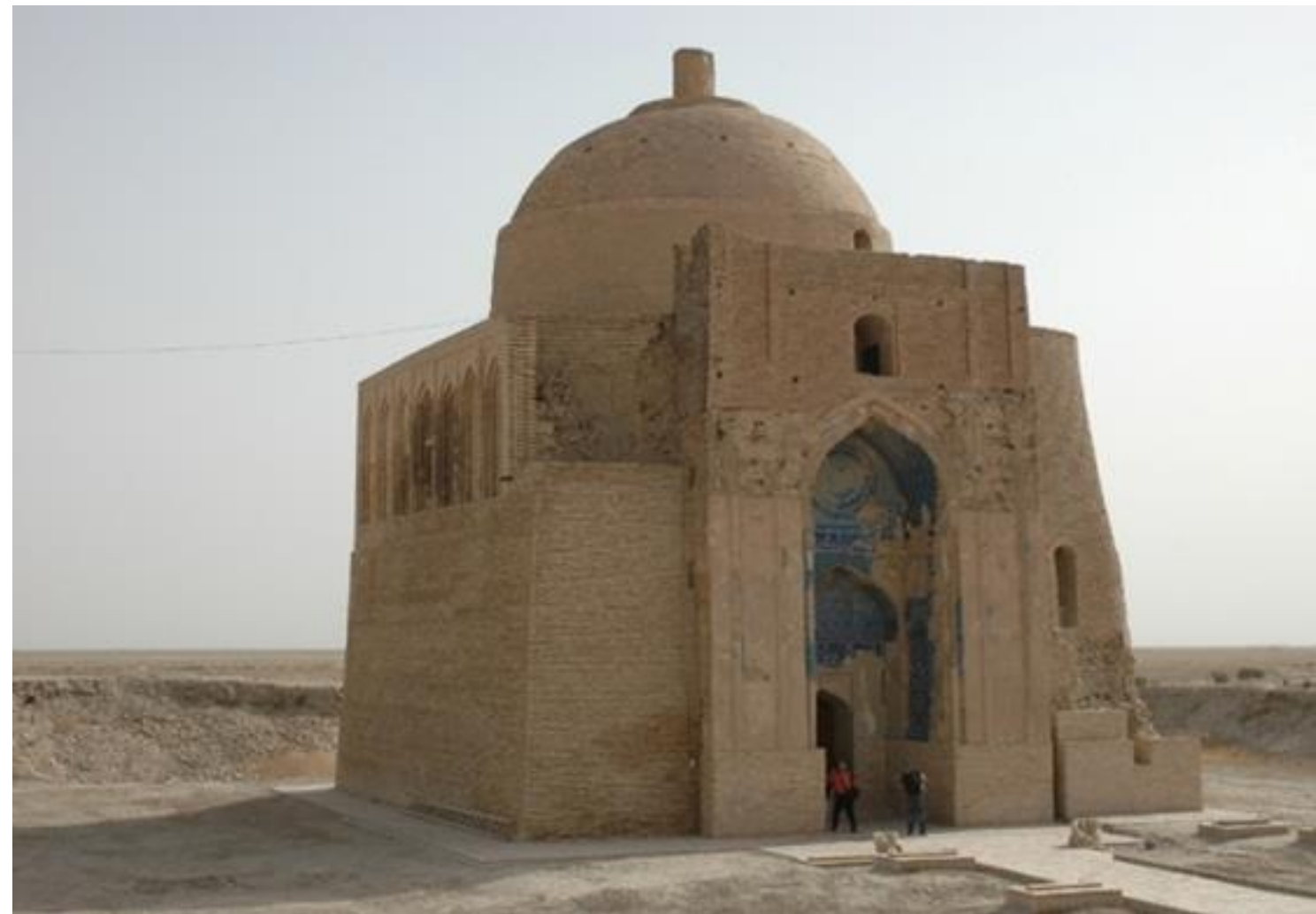

Figure 258: Mane Mausoleum, 892 AD

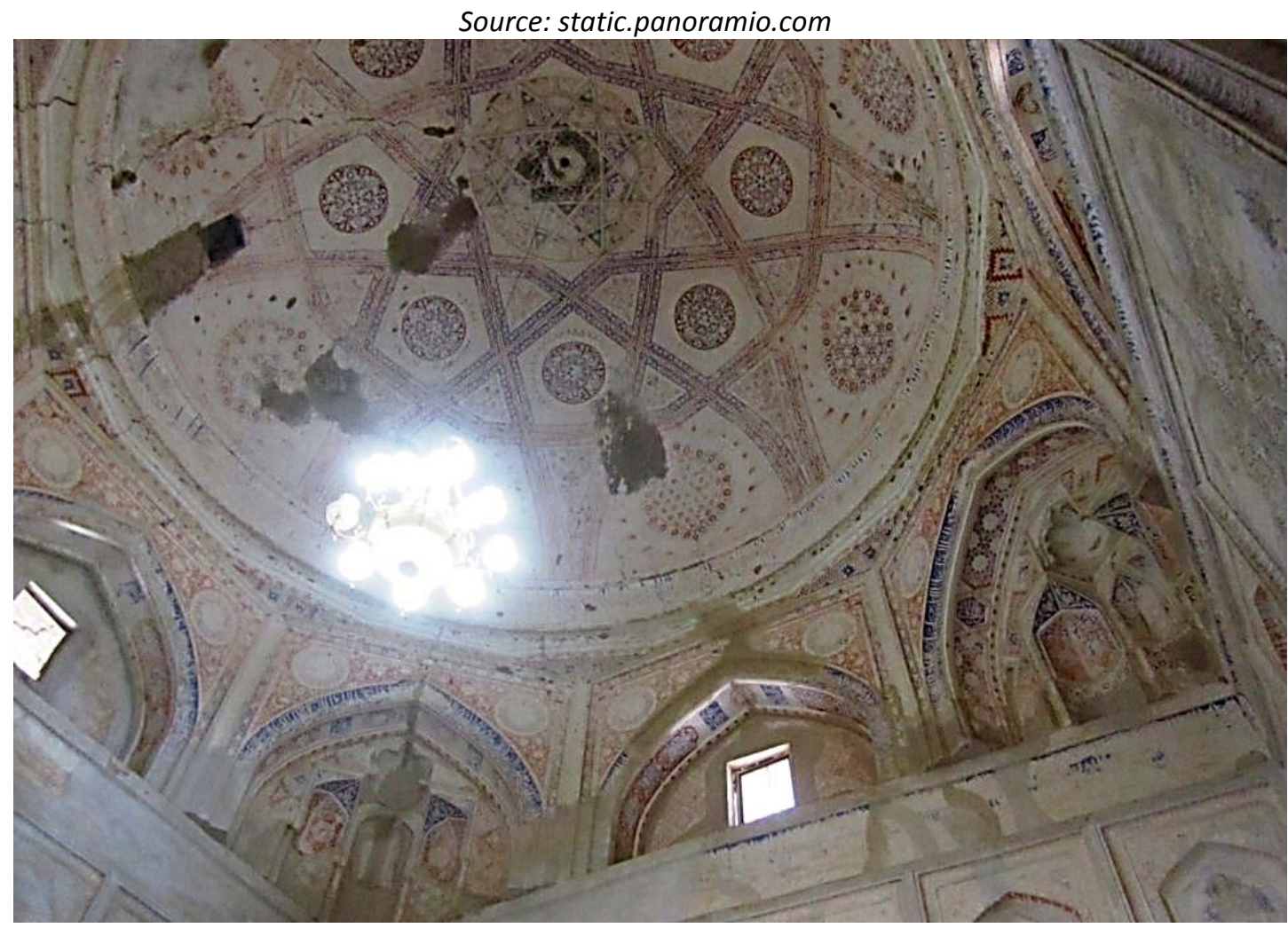

Figure 259: Kashan style with eight-pointed tiles

Source :Orex 